\author{
UNIVERSIDADE DE SÃO PAULO \\ PROGRAMA DE PÓS-GRADUAÇÃO INTERUNIDADES EM \\ ESTÉTICA E HISTÓRIA DA ARTE
}

LUIZA MADER PALADINO

\title{
CONCEITUALISMOS EM TRÂNSITO: INTERCÂMBIOS ARTÍSTICOS ENTRE BRASIL E ARGENTINA NA DÉCADA DE 1970 - MAC USP E CAYC
}




\section{Luiza Mader Paladino}

\section{CONCEITUALISMOS EM TRÂNSITO: INTERCÂMBIOS ARTíSTICOS ENTRE BRASIL E ARGENTINA NA DÉCADA DE 1970 - MAC USP E CAYC}

Dissertação apresentada ao Programa de Pós-Graduação Interunidades em Estética e História da Arte da Universidade de São Paulo para obtenção do título de Mestre em Estética e História da Arte.

Área de concentração: Teoria e Crítica de Arte

Orientadora: Profa. Dra. Maria Cristina Machado Freire 
Autorizo a reprodução e divulgação total ou parcial deste trabalho, por qualquer meio convencional ou eletrônico, para fins de estudo e pesquisa, desde que citada a fonte.

Catalogação da Publicação

Biblioteca Lourival Gomes Machado

Museu de Arte Contemporânea da Universidade de São Paulo

Paladino, Luiza Mader.

Conceitualismos em trânsito: intercâmbios artísticos entre Brasil e Argentina na década de 1970 - MAC USP e CAYC / Luiza Mader Paladino; orientadora Maria Cristina Machado Freire. - São Paulo, 2015.

212 f.: il.

Dissertação (Mestrado - Programa de Pós-Graduação Interunidades em Estética e História da Arte) - Universidade de São Paulo, 2015.

1. Arte Conceitual - Brasil - Anos 1970. 2. Arte Conceitual - Argentina Anos 1970. 3. Acervo Museológico - Brasil. 4. Universidade de São Paulo. Museu de Arte Contemporânea. 5. Centro de Arte y Comunicación. I. Freire, Cristina. II. Título. 


\section{Luiza Mader Paladino}

Conceitualismos em trânsito: intercâmbios artísticos entre Brasil e Argentina na década de 1970 - MAC USP e CAYC.

Dissertação apresentada ao Programa de Pós-Graduação Interunidades em Estética e História da Arte da Universidade de São Paulo para obtenção do título de Mestre em Estética e História da Arte.

Área de concentração: Teoria e Crítica de Arte.

Aprovada em:

Banca Examinadora

Prof. Dr. Instituição:

Julgamento: Assinatura:

Prof. Dr. Instituição:

Julgamento: Assinatura:

Prof. Dr. Instituição: Assinatura: 
Para Ana e José, meus pais, e para Helena, minha irmã. 


\section{Agradecimentos}

À minha orientadora, Cristina Freire, pelo acolhimento, pela generosidade ao compartilhar tantos ensinamentos e pela oportunidade de tornar este trabalho possível.

Às professoras pela leitura atenciosa, e por aceitarem gentilmente o convite para compor a minha defesa. À Daisy Peccinini e Lisbeth Rebollo, pela valiosa orientação na banca de qualificação.

Às amigas de toda uma vida: Juliana Gonçalves, Rebeca Damian, Camilla Shinoda, Nina Bianchetti, Nuara Vicentini, Bruna Maria, Talita Dias, Camila Soato e ao Fábio Baroli. À amizade incondicional de Rosângela Vieira, que me recebeu com generosidade quando cheguei a São Paulo. Às companheiras paulistanas Ana Lu, Marulina, Laura e Helô, que me acolheram com afeto na nova cidade. Ao Zuza, que seguiu desde o início esta pesquisa.

À minha tia Bel, pelo imenso apoio. Ao meu padrinho Rogério, por sempre me estimular com tantas conversas e carinho. E ao meu tio Hugo também! Aos meus irmãos, à Mari, pela ajuda nas imagens e ao meu afilhado Miguel, que me trouxe tanta alegria e leveza. Ao meu cunhado Gui, pelo auxílio na tradução. À tia Gilda e vó Luiza, minha pequena família de São Paulo.

Aos amigos do GEACC (Grupo de Estudos em Arte Conceitual e Conceitualismos no Museu), Eduardo Shoji, Bruno Sayão, Jonas Pimentel, Carolina Castanheda, Ana Paula Lopes, Emanuelle Schneider, Fernanda Porto, Júlia Coelho, Bárbara, Luise Malmaceda e Carmen Palumbo, pelo aprendizado dos nossos encontros, pelo incentivo e pela amizade. Um agradecimento especial às amigas tão queridas Adriana Palma e Heloisa Louzada.

A todos os funcionários do PGEHA, da biblioteca do MAC USP e, em especial, à Sara Viera. À Silvana Karpinsky, do arquivo do MAC USP, pelo auxílio neste trabalho. Aos funcionários dos arquivos do Masp, Di Tella, Fundación Espigas e CCSP.

Ao artista Horacio Zabala, pelos encontros no Rio de Janeiro e Buenos Aires. À potência crítica de sua obra, que foi a base inicial desta pesquisa.

Aos estudantes e professores envolvidos nos dois encontros do seminário da Getty Foundation, pelo rico aprendizado proporcionado nas trocas acadêmicas.

À Mryriam Kazue, pela revisão da dissertação.

À Coordenação de Aperfeiçoamento de Pessoal de Nível Superior (CAPES), pelo apoio financeiro para a realização da pesquisa. 
A opção pela América Latina, preferencialmente, não se fará por razões exclusivamente estéticas - que não existem e nunca existiram -, mas por razões morais, sociais, metafísicas, pelo entendimento de nós mesmos, onde estamos, e pelo que necessitamos de imediato, de nutritivo, de revigorante.

Não escolhemos a literatura latino-americana por ser superior ou mais qualificada, mas simplesmente porque nela estamos, nela somos. Do mesmo modo que não escolhemos a terra em que nascemos com seus problemas, entendemos que não atender a suas exigências, e inclusive a suas adversidades, implicaria uma traição que, mais que ao país ou à sociedade, seria a nós mesmos.

Ángel Rama, Literatura, cultura e sociedade na América Latina. 


\section{RESUMO}

PALADINO, Luiza Mader. Conceitualismos em trânsito: intercâmbios artísticos entre Brasil e Argentina na década de 1970 - MAC USP e CAYC. São Paulo, 2015. 212 p. Dissertação (Mestrado em Estética e História da Arte) - Programa de Pós-Graduação Interunidades em Estética e História da Arte da Universidade de São Paulo.

Esta dissertação apresenta uma reflexão sobre o intercâmbio artístico realizado entre São Paulo e Buenos Aires, no decorrer da década de 1970. Essa rede de trocas está focada no Museu de Arte Contemporânea da Universidade de São Paulo (MAC USP), sob a gestão de Walter Zanini, e no Centro de Arte y Comunicación (CAYC), dirigido por Jorge Glusberg. Para tanto, iniciamos com um breve estudo sobre as políticas de modernização cultural na Argentina e no Brasil, desde a fundação das primeiras instituições de caráter moderno, nas décadas de 1950 e 1960. Nessa trajetória, traçamos os locais na Argentina onde houve o estímulo às novas vanguardas, desde a ascensão da pop art até a desmaterialização do objeto artístico. Sabemos que o MAC USP e o CAYC constituíram-se como plataformas interdisciplinares e multimídias fundamentais para a ampliação e o incentivo das práticas experimentais, sobretudo da arte conceitual. Desse modo, estabeleceram-se como importantes polos de arte contemporânea na América Latina nesse período. Procuramos analisar os interesses particulares de ambas as gestões, o perfil institucional e os mecanismos de divulgação e circulação das propostas conceituais amparadas pelas duas entidades. E, por fim, mapeamos a presença dos artistas argentinos do Grupo de los Trece, ligados ao CAYC, no acervo do MAC USP.

Palavras-chave: Arte Conceitual, Arte Latino-Americana, Exposições de Arte. 


\begin{abstract}
PALADINO, Luiza Mader. Conceptualisms in transit: artistic Exchange between Brazil and Argentina in the 1970s - MAC USP and CAYC. São Paulo, 2015. 212 p. Dissertation (Masters in Esthetics and Art History) - Interunits Postgraduation program in Esthetics and Art History, Universidade de São Paulo.

This dissertation offers a reflection on the artistic exchange occurred between Sao Paulo and Buenos Aires in the 1970s. This reciprocal network is centered in the University of Sao Paulo's Museum of Contemporary Arte (MAC USP), under de auspice of Walter Zanini, and in Buenos Aires' Art and Communication Center (CAYC), directed by Jorge Glusberg. We begin with a brief study of cultural modernization programs in Brazil and Argentina, as of the establishment of the first institutions of a modern nature, in the 1950s and 1960s. In this trajectory we map venues in which new avant-garde were stimulated, from the dawn of pop art to the dematerialization of the artistic object. We demonstrate that MAC USP and CAYC established essential interdisciplinary and multimedia platforms aiming at amplifying and motivating experimental practices, especially concept art, thus constituting important loci of contemporary art in Latin America at that time period. We aim to analyze the particular interests of each administration, their institutional profile and mechanisms to broadcast and promote conceptual propositions sustained by each organization. Finally, we trace the presence of Argentine artists of Grupo Los Trece, associated to CAYC, in MAC USP's collection.
\end{abstract}

Key-words: Concept Art; Latin-American Art; Art Exhibits. 


\section{LISTA DAS IMAGENS}

Figura 1 - Ficha de inscrição de Horacio Zabala para participar da mostra Prospectiva 74, 1974. Obra: Integração de linguagens poéticas experimentais com investigações sociais e econômicas. Setor de Documentação do MAC USP.

Figura 2 - Frente do folder "Centro de Arte y Comunicación". Acervo da Biblioteca Lourival Gomes Machado, MAC USP.

Figura 3 - Vista da mostra $C A Y C$ al aire libre. Arte e Ideología, na praça Roberto Arlt, 1972.

Figura 4 - Trilha de açúcar. Projeto de Hélio Oiticica executado por Lee Jaffe, na Serra do Curral. Obra da manifestação Do corpo à terra, 1970.

Figura 5 - Vista parcial da mostra Década de 70. Fotógrafo: Gerson Zanini, 1976. Arquivo do MAC USP.

Figura 6 - Vista de parte da instalação Signos em ecossistemas artificiais. XIV Bienal de São Paulo, 1977

Figura 7 - Como ve un sudamericano el movimento artístico contemporaneo em Europa. Jorge Romero Brest, 1948.

Figura 8 - A arquitetura é a grande arte do nosso tempo. Folha da Manhã. 17 dez. 1950. Arquivo MASP.

Figura 9 - Unidade tripartida, Max Bill, 1948-1949. Aço inoxidável, 114,0 x 88,3 x 98,2 cm. Coleção MAC USP.

Figura 10 - La Ninfa Sorprendida, Édouard Manet, 1861. Óleo sobre tela. 144,5 x 112,5 cm. Museu Nacional de Bellas Artes.

Figura 11 - Vista do CAV - Centro de Artes Visuais. Instituto Di Tella, 1967. Exposição de Rômulo Macció. Arquivo Instituto Torcuato Di Tella.

Figura 12 - Vista do Prêmio Nacional e Internacional ITDT, 1962. (Detalhe da obra Bichos, de Lygia Clark). Arquivo Instituto Torcuato Di Tella.

Figura 13 - Vista da mostra Arte Destructivo. Galeria Lirolay, 1961. 
Figura 14 - La Destrucción, Marta Minujín. Fotografia, 1963.

Figura 15 - Vista do Prêmio Nacional e Internacional ITDT, 1964. (Detalhe da obra Revuélquese y viva!, de Marta Minujín)

Figura 16 - La muchacha del colchón. Jornal Para ti, 22 dez. 1964. Arquivo Instituto Torcuato Di Tella.

Figura 17 e 18 - La Menesuda, Marta Minujín e Rubén Santantonín. Instituto Di Tella, 1965. Arquivo Instituto Torcuato Di Tella.

Figura 19 - ¿Por qué son tan geniales? Edgardo Giménez, Carlos Squirru e Delia Puzzovio, 1965.

Figura 20 - Autorretrato, Dalila Puzzovio. Técnica mista, objetos e luz, 223 x 365,5 x 100 cm, 1966.

Figura 21 - Mensage en Di Tella, Roberto Jacoby, 1968. Arquivo Instituto Torcuato Di Tella.

Figura 22 -Familia Obrera, Oscar Bony. Instalação, 1968.

Figura 23 - Verificación esquemática, Antonio Trotta. Aço inoxidável e espelho, 1968. Arquivo Instituto Torcuato Di Tella.

Figura 24 - El baño, Roberto Plate. Dimensões variáveis. Obra censurada com faixas judiciais, 1968. Arquivo Instituto Torcuato Di Tella.

Figura 25 - Abaixo-assinado organizado pelos participantes de Experiencias 68. Arquivo Instituto Torcuato Di Tella.

Figura 26 - Folder do Ciclo de Arte Experimental, Graciela Carnevale, 1968. Arquivo Instituto Torcuato Di Tella.

Figura 27 - Tucumán Arde. Fotografia, 1968.

Figura 28 - Sobre relieve, Gyula Kosice. Gás neon, 65 x 37,5 x 17 cm, 1950.

Figura 29 - Situación de tiempo, David Lamelas. Instalação com 17 televisores, 1967. Arquivo Instituto Torcuato Di Tella.

Figura 30 - Sem título, Antonio Berni, 1969. 
Figura 31 - Biotrón, Luis Fernando Benedit. Instalação, 300 x 500 x 200 cm, 1970.

Figura 32 - Analogía I, Victor Grippo. Instalação, 47,4 x 153 x 10 cm, 1970-1971.

Figura 33 - Escultura, follaje y ruidos. Edgardo Antonio Vigo em uma ação. Praça Rubén Darío, Buenos Aires, 1970.

Figura 34 - Una exhibición organizada por Lucy Lippard y Jorge Glusberg. Gacetilla GT 28-11-70. ICCA - Documents of 20th-Century Latin American and Latino Art.

Figura 35 - Vista da mostra Hacia un perfil del arte latinoamericano (cat. exp.). Bienal Coltejer, Medellín, 1972.

Figura 36 - Obras apresentadas na mostra Hacia un perfil del arte latinoamericano (cat. exp.). Luis Pazos, 1972.

Figura 37 - Obra apresentada na mostra Arte de Sistemas (cat. exp.). Juan Pablo Renzi, 1971.

Figura 38 - Arte de Sistemas en el Museo de Arte Moderno. Gacetilla GT 54. 28-06-1971. ICCA - Documents of 20th-Century Latin American and Latino Art.

Figura 39 - Tierra, Carlos Ginzburg. Arte de Sistemas, 1971.

Figura 40 - Obra apresentada na mostra Arte de Sistemas (cat. exp.). Jorge Gutiérrez, Luis Pazos, Hector Puppo, 1971.

Figura 41 - La cultura de la felicidad. Jorge Gutiérrez, Luis Pazos, Hector Puppo. Fotografia P\&B, 30 x 40 cm, 1971.

Figura 42 - Obra apresentada na mostra Arte de Sistemas (cat. exp.). Vicente Marotta, 1971.

Figura 43 - La realidade subterranea. Luis Pazos, Roberto Duarte, Eduardo Leonetti e Ricardo Roux , 1972.

Figura 44 - 300 metros de cinta negra para enlutar una plaza pública. Horacio Zabala, 1972.

Figura 45 - Construcción de un horno popular para hacer pan. Victor Grippo e Jorge Gamarra, 1972. 
Figura 46 - Situações T/T, Artur Barrio. Trouxas de pano, ossos, carne, sangue, barro, espuma de borracha, cordas, 1970.

Figura 47 - Tiradentes: Totem-monumento ao preso político, Cildo Meireles. Estaca de madeira, tecido branco, termômetro clínico, 10 galinhas, gasolina, fogo, 1970.

Figura 48 - 300 metros de conta negra para enlutar uma plaza publica (cat. exp.), Horacio Zabala. CAyC al aire libre. Buenos Aires, 1972.

Figura 49 - El arte como conciencia en la Argentina. Gacetilla GT 138 22-06-72. ICCA Documents of 20th-Century Latin American and Latino Art.

Figura 50 - Integração de linguagens poéticas experimentais com investigações sociais e econômicas. Horacio Zabala. Selo, datilografia e tipografia sobre envelope, fita adesiva, papel carbono e carimbo sobre mapa impresso (Detalhe), 152,5 x $75 \mathrm{~cm}$, Coleção MAC USP

Figura 51 - Este papel es una cárcel, Horacio Zabala. Fotografia, 1972.

Figura 52 - Seis imágenes del fragmento 30, Horacio Zabala. Grafite sobre papel e mapa impresso queimado, 1973.

Figura 53 - Forma y función, Horacio Zabala. Garrafas de vidro, líquido, flor, texto sobre papel, 1972-2011.

Figura 54 - Mirá como tiemblo, Horacio Zabala.Tubo de aerossol e isqueiro, 2002.

Figura 55 - Vista da $\boldsymbol{V I} \boldsymbol{J} \boldsymbol{A} \boldsymbol{C}$. MAC USP, 1972

Figura 56 - Sorteio dos lotes da VI JAC. MAC USP, 1977

Figura 57 - Edgardo Antonio Vigo. Obra enviada para o livro Contrabienal, 1971. ICCA Documents of 20th-Century Latin American and Latino Art.

Figura 58 - Repolhos, Marta Minujín. Performance no MAC USP, 1977.

Figura 59 - Vista da exposição Prêmio Nacional Di Tella (detalhe), 1964. Arquivo Instituto Torcuato Di Tella.

Figura 60 - Farmácia Fischer \& Cia, Hervé Fischer, 1976.

Figura 61 - Gacetilla GT 26-06-75, Farmacia Fischer \& Cia, 1975. Biblioteca Lourival Gomes Machado. 
Figura 62 - Catálogo da mostra Papel e Lápis, 1976, MAC USP. Biblioteca Lourival Gomes Machado.

Figura 63 - Gacetilla GT 24-09-73. Exhibición homenaje a Salvador Allende, 1973. ICCA - Documents of 20th-Century Latin American and Latino Art.

Figura 64 - Hombres Anuncio, Isidoro Válcarcel Medina, 1976.

Figura 65 - Gacetilla GT 04-12-73. Exprojeção 73, 1973. Arquivo MAC USP.

Figura 66 - Gacetilla GT 27-07-75. Julio Plaza exposición, 1975. Arquivo MAC USP.

Figura 67 - Painel com as correspondências dos participantes de Prospectiva 74. Fotógrafo: Gerson Zanini, 1974. Arquivo MAC USP.

Figura 68 - Catálogo da mostra Prospectiva 74. Concepção: Julio Plaza, 1974. Banco de dados do MAC USP.

Figura 69 - Vista parcial da mostra Prospectiva 74. Fotógrafo: Gerson Zanini, 1974. Arquivo MAC USP.

Figura 70 - Luis Pazos, Transformaciones de masa en vivo. Registro de performance, 1973.

Figura 71 - La ciudad poseída por los demonios, Luis Pazos, Registro de performance, 86, 1 x $58 \mathrm{~cm}$ (detalhe), 1974. Banco de Dados do MAC USP

Figura 72 - Violencia, Juan Carlos Romero. Detalhe das obras enviadas para Prospectiva 74, 1974. Banco de Dados do MAC USP.

Figura 73 - Vista parcial da mostra Década de 70. Fotógrafo: Gerson Zanini, 1976. Arquivo do MAC USP.

Figura 74 - Vista parcial da mostra Década de 70. Fotógrafo: Gerson Zanini, 1976. Arquivo do MAC USP.

Figura 75 - Detalhe do catálogo da mostra Década de 70, 1976. Biblioteca Lourival Gomes Machado. 
Figura 76 - Instalação do Grupo Etsedron. XIII Bienal Internacional de São Paulo, 1975.

Figura 77 - Vista parcial da instalação Signos em Ecossistemas Artificiais. Detalhe da obra Factor Interespecífico, de Jorge González Mir. XIV Bienal Internacional de São Paulo, 1977.

Figura 78 - Vista parcial da instalação La última Cena, de Leopoldo Maler. XIV Bienal Internacional de São Paulo, 1977.

Figura 79 - Jorge Glusberg e o governador do Estado de São Paulo, Egydio Martins, diante da obra de Jacques Bedel. XIV Bienal Internacional de São Paulo, 1977.

Figura 80 - Felicitó Videla a los premiados en San Pablo. La nación. Arquivo Multimeios do Centro Cultural São Paulo 


\section{LISTA DAS SIGLAS}
AMAB
Associação de Museus de Arte do Brasil
CAYC - Centro de Arte y Comunicación
CAV $\quad-\quad$ Centro de Artes Visuais
EAE $\quad-\quad$ Escuela de Altos Estudios
ITDT $\quad-\quad$ Instituto Torcuato Di Tella
JAC $\quad-\quad$ Jovem Arte Contemporânea
MAC USP - $\quad$ Museu de Arte Contemporânea da Universidade de São Paulo
MoMA $\quad-\quad$ Museu de Arte Moderna de Nova Iorque
MAM $\quad-\quad$ Museu de Arte Moderna de Buenos Aires
MAM SP - $\quad$ Museu de Arte Moderna de São Paulo
MAM RJ - $\quad$ Museu de Arte Moderna do Rio de Janeiro
MNBA $\quad-\quad$ Museu Nacional de Belas Artes de Buenos Aires 


\section{ARquivos Pesquisados}

\section{BuenOS AIRES:}

Instituto Torcuato Di Tella

Fundación Espigas

\section{SÃo PaUlo:}

Museu de Arte Contemporânea da Universidade de São Paulo - MAC USP

Museu de Arte de São Paulo - MASP

Arquivo Multimeios do Centro Cultural São Paulo - CCSP

\section{INTERNET:}

Documents of 20th-Century Latin American and Latino Art - ICCA 


\section{SUMÁRIO}

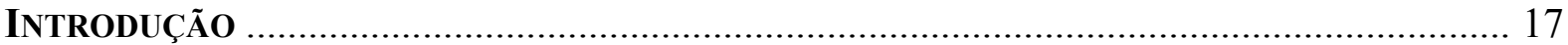

CAPÍTUlO 1 - BREVE TÓPICO SOBRE A MODERNIZAÇÃo CULTURAL NA AMÉRICA

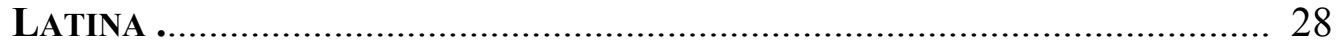

1.1 - PREÂMbULOS PARA ALGUNS ESTUdos DE CASO ..................................................... 33

1.1.1. INTERCÂMBIOS ARTÍSTICOS ENTRE BRASIL E ARgENTINA: BIENAL E MAMS ............. 33

1.1.2. OUTRAS REFLEXÕES SOBRE O CASO ARGENTINO ...................................................... 42

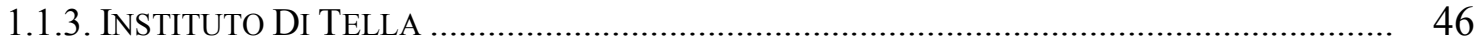

1.1.4. POP, HAPPENING E ARTE DE LOS MEDIOS …….................................................. 59

1.1.5. EXPERIENCIAS 68: RUMO À RADICALIZAÇÃO POLÍTICA ……………….................... 76

CAPÍtulo 2 - Centro de Arte y Comunicación - CAYC ….................................... 90

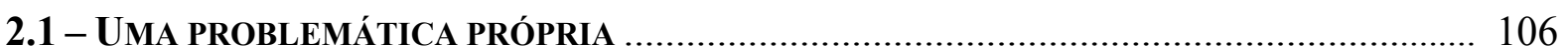

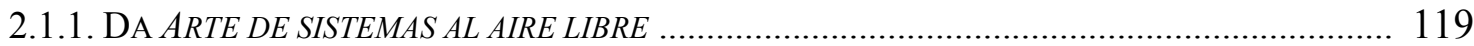

2.1.2. ESTUDO DE CASO: OS MAPAS DE HORACIO ZABALA .................................................... 134

CAPÍTULO 3 - INTERCÂMBIO INSTITUCIONAL ENTRE BRASIL E ARGENTINA DA

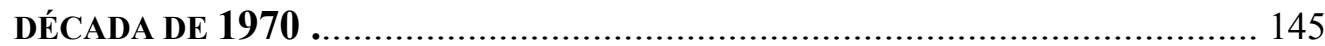

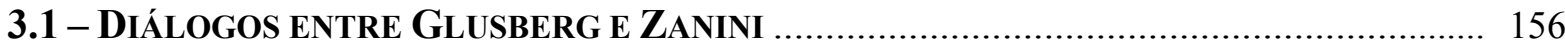

3.1.1. PROSPECTIVA 74: ARGENTINOS NO MAC USP ..................................................... 170

3.1.2. DÉCADA DE 70: CONSOLIDAÇÃO DE TROCAS ARTÍSTICAS ........................................ 180

3.1.3. SIGNOS EM ECOSSISTEMAS ARTIFICIAIS: UMA PREMIAÇÃO POLÊMICA …………........... 185

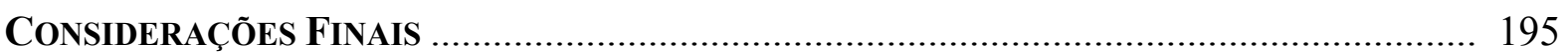

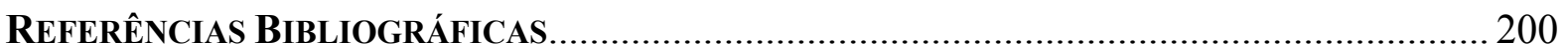




\section{INTRODUÇÃo}

O objetivo inicial desta pesquisa era investigar as obras cartográficas do artista argentino Horacio Zabala produzidas durante a década de 1970, com foco nos trabalhos do acervo do Museu de Arte Contemporânea da Universidade de São Paulo. O argentino enviou ao MAC USP, a convite de Walter Zanini, uma série de intervenções cartográficas para participar da mostra Prospectiva $74^{1}$, intitulada Integração de linguagens poéticas experimentais com investigações sociais e econômicas. Zabala foi integrante do Grupo de los Trece $^{2}$, um grupo de artistas capitaneado por Jorge Glusberg, diretor do Centro de Arte y Comunicación - CAYC, de Buenos Aires. Sabemos que o MAC USP e o CAYC foram duas instituições fundamentais para a ampliação e o incentivo das práticas experimentais e que, nesse mesmo período, estabeleceram uma rede de contatos e intercâmbios artísticos.

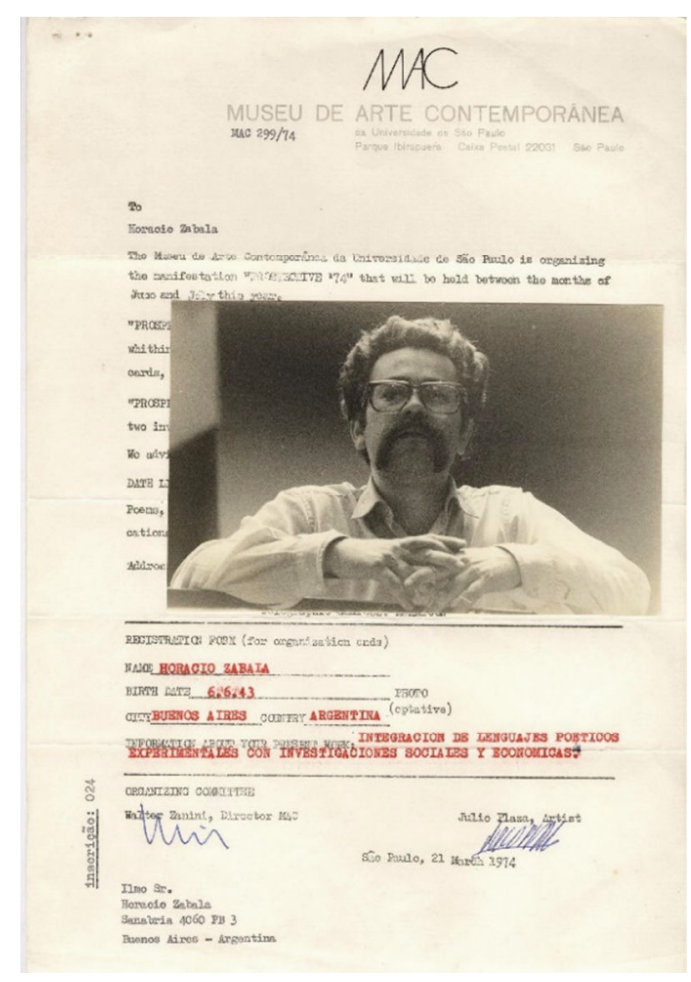

Figura 1 - Ficha de inscrição de Horacio Zabala para participar da mostra Prospectiva 74 (1974).

Obra: Integração de linguagens poéticas experimentais com investigações sociais e econômicas Setor de Documentação do MAC USP

\footnotetext{
${ }^{1}$ A mostra foi uma convocatória internacional de arte postal organizada por Zanini e pelo artista espanhol Júlio Plaza.

${ }^{2}$ Grupo criado por Jorge Glusberg em 1971, composto pelos artistas Jacques Bedel, Horacio Zabala, Juan Carlos Romero, Luis Pazos, Luis Fernando Benedit, Carlos Ginzburg, Gregorio Dujovny, Alfredo Portillos, Víctor Grippo, Jorge González Mir, Vicente Marotta, Julio Teich e o próprio Glusberg. Em 1975, mudaram o nome para Grupo CAYC.
} 
O MAC USP, instituição pública ligada à Universidade de São Paulo, teve a direção de Walter Zanini desde o ano de sua inauguração, em 1963, até 1978. Com uma ampla programação e poucos recursos financeiros, o Museu tornou-se um território dialético em que coexistia o incentivo à organização do acervo de arte moderna com uma série de mostras retrospectivas, em paralelo ao impulso à produção de arte contemporânea. Zanini desenvolveu uma plataforma interdisciplinar e multimídia (FREIRE, 2013, p. 28), dando fôlego às práticas conceituais, às novas tecnologias e potencializando uma rede internacional de trocas artísticas, por meio da arte postal.

Digamos que o museu já começou a conhecer uma fase de transição: se ainda permanece como uma instituição de seleção e preservação da obra tradicional, a sua função receptiva começa a franquear lugar a uma forma revolucionária de participação ativa e direta no contexto criador. [...] Diante da celeridade das manifestações de natureza efêmera, possuidoras de uma carga extraordinária de informação e onde são implícitas as motivações interdisciplinares, o museu obviamente não poderá guardar o distanciamento de outrora. [...] Entre seus objetivos deverá estar o de proporcionar aos artistas espaços novos de exibições, recursos para ações e, em certos casos instrumentais, de converter-se em um núcleo de energia que permita encontros de artistas e relacionamentos destes com estudiosos e o público em geral. (Zanini, 1972, apud FREIRE, 2013) ) $^{3}$

Distinto do caráter público e universitário do MAC USP, o CAYC, instituição privada, criada e dirigida por Jorge Glusberg em 1968, deu início a um novo panorama artístico em Buenos Aires. Em sua fase de formação, o Centro estimulou o vínculo entre arte e tecnologia; contudo, no decorrer dos anos seguintes, consolidou-se a partir de uma dupla operação: associar-se às poéticas conceituais, com foco no contexto latino-americano, simultâneo ao projeto de internacionalização da arte local. Teve grande relevância como espaço interdisciplinar e articulou-se a partir dos eixos da arte, comunicação e arquitetura.

La articulación del sistema de atividades del CAYC reposa sobre tres ejes essenciales: el arte, la arquitectura y la Comunicación. [...] La integración cultural, finalidad básica base del CAYC - integración de las diversas disciplinas, integración de la teoría y de él un centro comunicante que vincula áreas geográficas a través del intercambio de personas y la circulación de obras e información, tanto en plano nacional como en el internacional (GLUSBERG, 1969). ${ }^{4}$

\footnotetext{
${ }^{3}$ O Museu e o artista. Texto apresentado no VI Colóquio da Associação dos Museus de Arte do Brasil - AMAB, realizado no MAM RJ, 1972. In: FREIRE, Cristina. (Org.). Walter Zanini: escrituras críticas. São Paulo: Annablume: MAC USP, 2013.

4 “A articulação do sistema de atividades do CAYC repousa sobre três eixos essenciais: a arte, a arquitetura e a comunicação. [...] A integração cultural, finalidade básica do CAYC - integração de diversas disciplinas,
} 


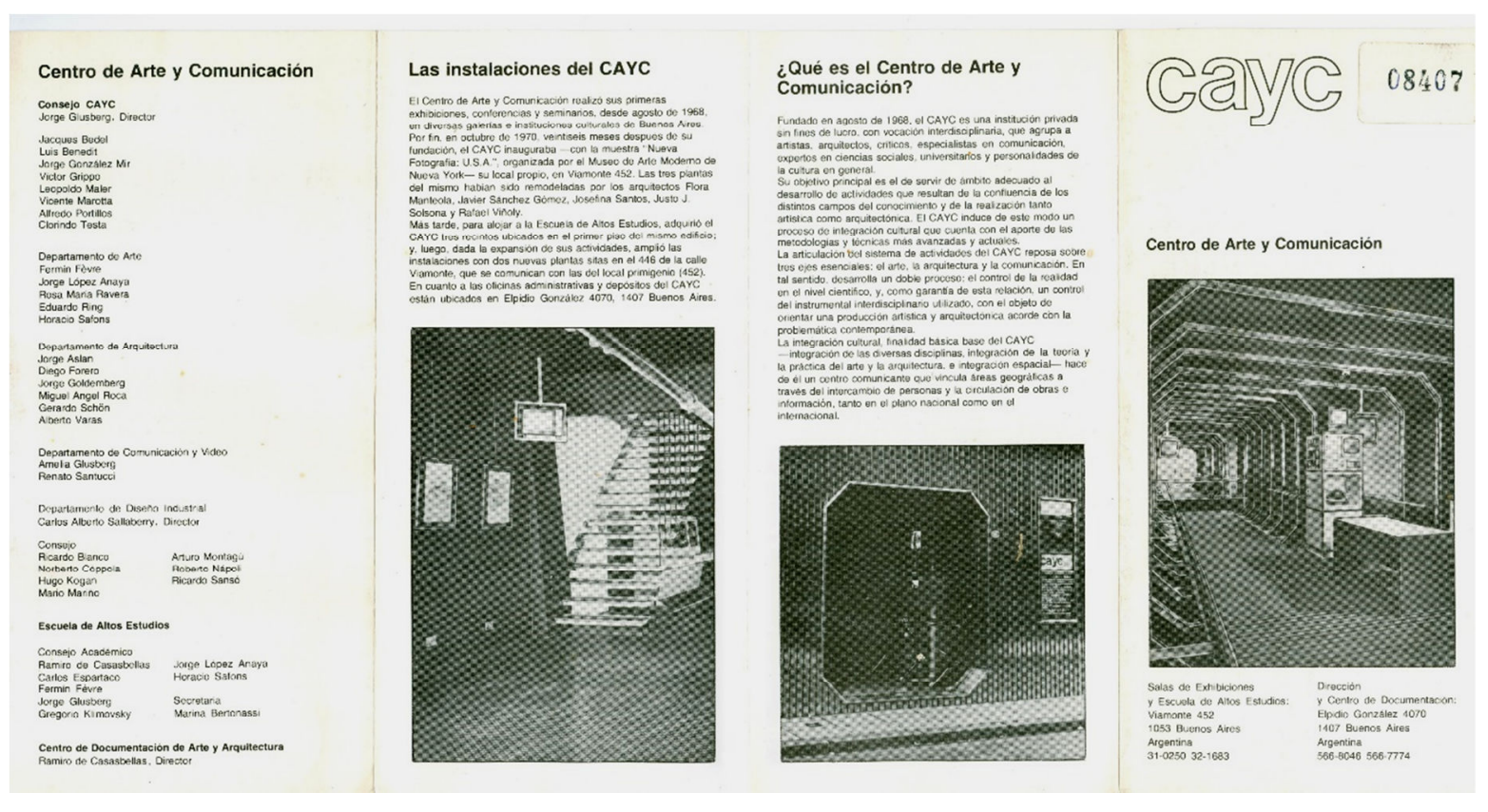

Figura 2 -Frente do folder Centro de Arte Y Comunicación

Acervo da Biblioteca Lourival Gomes Machado

Ao traçar o perfil das duas instituições, começamos a mapear a trajetória de Zabala nessas entidades identificando os aspectos de sua produção com os parâmetros teóricos, artísticos e conceituais promovidos pelo CAYC. Sobretudo os que se baseavam na categoria arte de sistemas, ou seja, "a arte como ideia, a arte política, a arte ecológica, a arte de proposições ou a arte cibernética". 5 partir do levantamento bibliográfico e da análise de documentos no arquivo do MAC USP, iniciamos uma busca nas correspondências trocadas entre Walter Zanini, Jorge Glusberg, Horacio Zabala e outros artistas argentinos do mesmo círculo. Assim, fomos seguindo rumos mais amplos, abarcando um eixo mais complexo de relações e intercâmbios institucionais que foram possíveis nesta pesquisa, por meio do primeiro objeto: as cartografias de Horacio Zabala.

A pesquisa da documentação nos mostrou que Zanini e Glusberg estabeleceram, no decorrer da década de 1970, um intenso diálogo através da tentativa de partilhar exposições; negociar a vinda de artistas e intelectuais internacionais, intermediar propostas e convites para

integração da teoria e de um centro comunicante que vincula áreas geográficas por meio do intercâmbio de pessoas e da articulação de obras e informação, tanto em plano nacional quanto no internacional." (GLUSBERG, Jorge. Qué es el CAYC. In: Palabra de artistas. Textos sobre arte argentino, 1961-1981, tradução nossa).

${ }_{5}^{5}$ Mesmo título da emblemática exposição organizada por Glusberg em 1971, que reuniu centenas de artistas nacionais e estrangeiros. Arte de Sistemas I, em compasso com as tendências artísticas internacionais da arte conceitual, arte povera e land art, se referia "a processos mais que a produtos finalizados da "boa arte", segundo o diretor do CAYC. (GLUSBERG, Jorge. Arte de Sistemas, cat. exp., Museu de Arte Moderna, 1971.) 
a participação de seminários e congressos. E, sobretudo, compartilhar o desafio de dirigir duas instituições em "temps difficiles", conforme escreveu Zanini a Glusberg, em uma das trocas de correspondência. ${ }^{6}$ Desse modo, o trabalho foi acrescentando outras perspectivas a partir da análise das trocas promovidas pelo MAC USP e CAYC, gerando novos elementos para este estudo. Sendo assim, o objeto inicial - as obras cartográficas - foi ampliado e passou a abranger o exame dessa fértil rede de câmbios institucionais que possibilitou a vinda de diversos artistas argentinos para o Museu, entre eles, o próprio Zabala.

Para mapear criticamente e compreender as particularidades dessa rede institucional ao longo da década de 1970, iniciaremos com um breve estudo sobre as políticas de modernização cultural na América Latina, com foco no caso argentino, no Capítulo 1. Sabemos que essas políticas deram impulso a criação de um novo aparato institucional modernizado, ao longo das décadas de 1940 e 1950, em um panorama marcado pela Guerra Fria e a pela presença dos EUA na região. Essa conjuntura geopolítica colaborou, de certa forma, no processo de fundação das primeiras instituições de arte moderna na Argentina e no Brasil, que sustentaram uma imagem inovadora por meio do estímulo à arte abstrata. A criação dos Museus de Arte Moderna do Rio de Janeiro e de São Paulo, do Museu de Arte de São Paulo (MASP) e, sobretudo, da Bienal de São Paulo, fez do Brasil uma peça-chave na trama regional, tornando-o uma vitrine internacional da renovação das linguagens artísticas. Veremos, também, que a relação entre o meio artístico brasileiro e o argentino foi gradualmente intensificada ao longo desses anos. Dois exemplos que confirmam esse interesse mútuo foram a itinerância da mostra Do figurativismo ao abstracionismo (1949), realizada no MAM SP, para Buenos Aires, e, em segundo, a vinda do crítico argentino Jorge Romero Brest ao Brasil, para participar de um ciclo de palestras no MASP e atuar como jurado das primeiras Bienais.

Durante esse período, a Argentina viveu um isolamento cultural atribuído às políticas culturais da primeira fase do peronismo (1946-1952), encontrando-se à margem dos novos códigos estéticos que haviam sido patrocinados pela nova burguesia cultural paulistana. Pouco a pouco, diversos atores culturais argentinos procuraram revigorar a programação de seus aparatos institucionais, e o Instituto Torcuato Di Tella talvez tenha assumido esse papel com maior protagonismo. Na década de 1960, o Di Tella contou com uma nova modalidade de mecenato cultural privado, ligado aos setores da burguesia industrial, promovendo o surgimento de novas vanguardas.

\footnotetext{
${ }^{6}$ FMACUSP 0046-003, 25 set.1973. Arquivo do Museu de Arte Contemporânea da Universidade de São Paulo.
} 
Iremos nos debruçar sobre as atividades do Instituto Di Tella e a atualização artística que agenciou por meio da organização de mostras, premiações e o estímulo às novas linguagens artísticas, que iam da pop art, arte ambiental ao happening. A análise de algumas exposições, como o Prêmio Instituto Torcuato Di Tella (1964) e a obra La Menesuda (1965), de Marta Minujín, mostrarão a rápida ascensão da pop art no país. Por sua vez, a exposição Experiencias 68 evidenciará a gradual desmaterialização do objeto artístico à radicalização política, lembrando que em 1966 a Argentina instaurou um regime militar no país. Esse ambiente de conflito marcou o encerramento das atividades do Di Tella, em 1970.

Abordaremos no Capítulo 2 a abertura do Centro de Arte y Comunicación (CAYC), instituição que deu continuidade à renovação das linguagens artísticas iniciada pelo Di Tella na década anterior. Contudo, Jorge Glusberg, seu diretor, procurou se apoiar em outro tipo de programa institucional, traçando diversas estratégias para internacionalizar a arte argentina, sobretudo com a atualização local da arte conceitual. A ambição de trazer propostas inéditas ao seu país, sempre buscando correlatos de exposições e experiências contemporâneas no estrangeiro, também caracterizou a coordenação do CAYC. Na Argentina, o Centro foi pioneiro na investigação entre arte e tecnologia, com a mostra Arte y cibernética (1969), que contou com a colaboração de engenheiros e artistas que utilizaram memórias de um computador IBM e uma máquina de desenho automático.

Nos primeiros anos da década de 1970, o CAYC organizou exposições, reuniões de intelectuais e formou um coletivo artístico próprio: o Grupo de los Trece, que operou a partir da categoria "arte de sistemas". O Grupo procurava pautar os trabalhos artísticos "sobre o espaço e no espaço social" (HERRERA, 2013, p. 13). O termo "arte de sistemas" se ajustou às tendências conceituais da época, onde houve uma gradual perda na ênfase do objeto artístico em favor do processo ou das ideias. Entretanto, Glusberg se apoiou em uma versão regional da arte conceitual, seguindo a noção de uma "arte pobre" orientada pelas reais condições de produção dos artistas latino-americanos, que fora intitulada como "conceitualismo ideológico". Ou seja, "como una forma que emerge como consecuencia de una problemática regional que utiliza una metodologia común a diferentes contextos" (GLUSBERG, 1972) ${ }^{7}$. A partir do entendimento do ajuste das vertentes conceituais na Argentina e das políticas institucionais arquitetadas por Jorge Glusberg, examinaremos algumas exposições emblemáticas realizadas pelo CAYC, como Arte de sistemas (1971) e

\footnotetext{
7 “Como uma forma que emerge como consequência de uma problemática regional que utiliza uma metodologia comum a diferentes contextos" (tradução nossa).
} 
CAYC al aire libre. Arte e ideología (1972), em que várias obras foram censuradas pelo forte teor político. Foram duas mostras com um número amplo de artistas nacionais e internacionais, e muitos deles participaram com o envio de obras heliográficas. Vale mencionar que o uso do papel heliográfico tornou-se um suporte privilegiado de exibição e circulação de obras, por ser um sistema econômico e facilmente reprodutível. Sobre esse novo canal de comunicação, os artistas conscientes de suas realidades nacionais, se manifestaram sob o prisma da arte como forma ideológica, em compasso com a sentença: "no existe una arte dos países latinoamericanos, pero sí una problemática própia, consecuente con su situación revolucionária" (GLUSBERG, 1972) ${ }^{8}$.

Ao examinarmos CAYC al aire libre. Arte e ideología, apresentaremos a manifestação Do corpo à terra, de 1970, organizada por Frederico Morais no Parque Municipal de Belo Horizonte. Ambas as mostras buscaram ativar o espaço público, ao lidarem com trabalhos no sentido de "guerrilha", como formas de "emboscada", provocando um estado de constante tensão entre a obra e o público. É válido expor as duas propostas na sequência, para ampliar os campos de experimentação, as táticas de "guerrilha artística" utilizadas em momentos simultâneos de adversidades políticas e sociais, além do confronto com as linguagens tradicionais das artes visuais que os artistas procuraram acionar.

\footnotetext{
8 "Não existe uma arte dos países latino-americanos, mas uma problemática própria, consequente com a sua situação revolucionária." (tradução nossa).

${ }^{9}$ Termo utilizado pelo crítico e historiador da arte Frederico Morais no texto Contra o corpo afluente: o corpo é o motor da "obra”. In: Revista Cultura Vozes, Rio de Janeiro, v. 1, n. 64, jan./fev. 1970.
} 


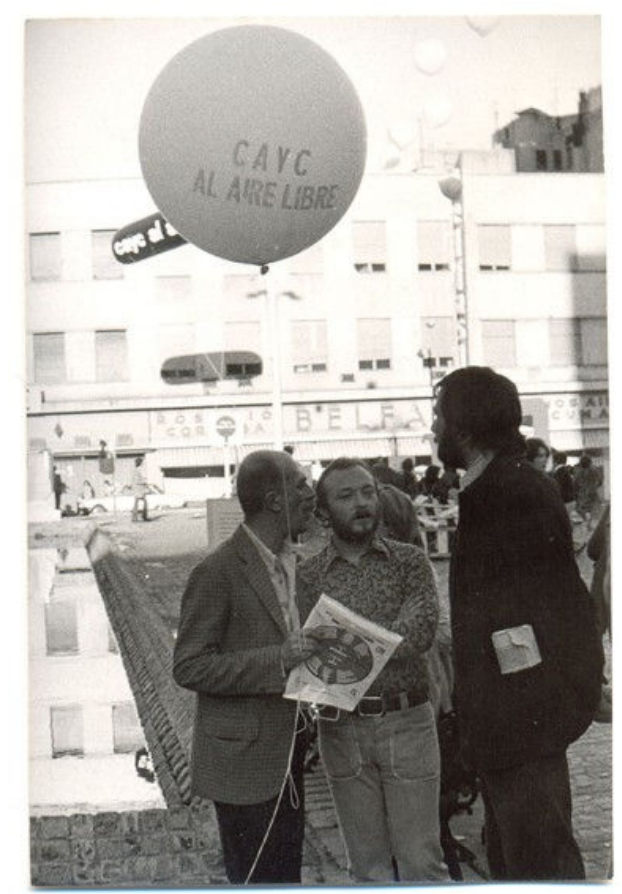

Figura 3 - Vista da mostra CAYC al aire libre. Arte e Ideología, na praça Roberto Arlt (1972).

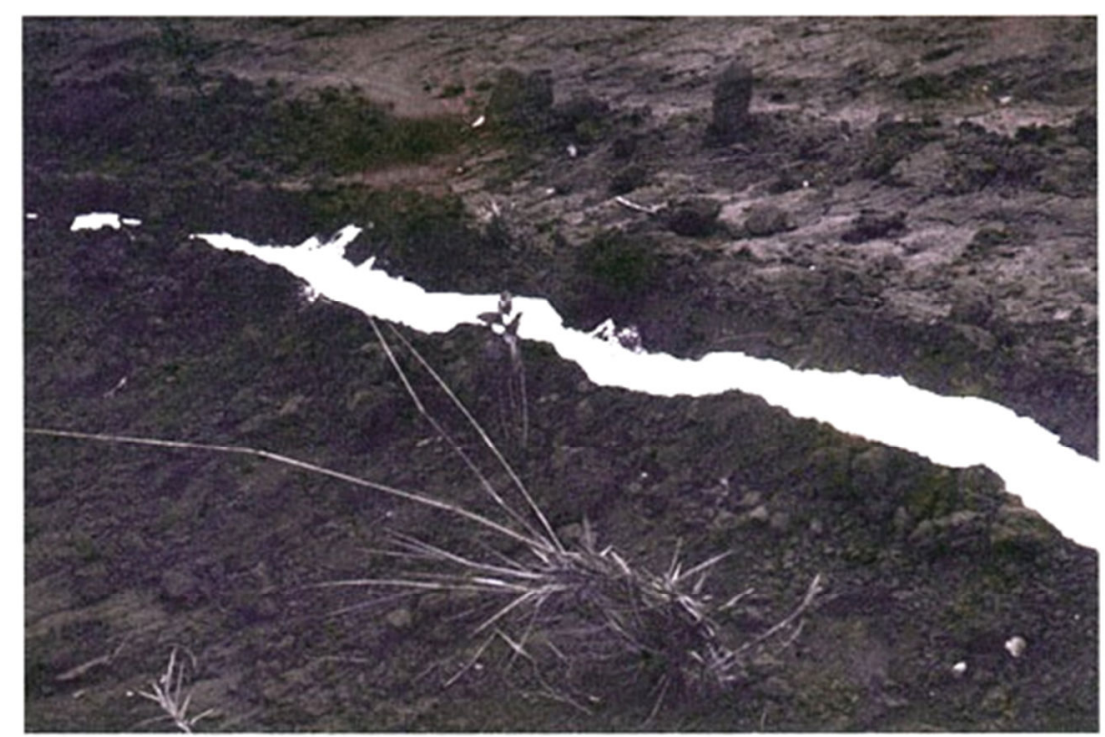

Figura 4 - Trilha de açúcar. Projeto de Hélio Oiticica executado por Lee Jaffe, na Serra do Curral. Obra da manifestação Do corpo à terra, 1970.

Por último, faremos um estudo de caso da obra cartográfica do artista Horacio Zabala. Proporemos uma leitura dessas obras na chave da reivindicação por uma experiência espacial política, como forma de sugerir outras construções simbólicas no espaço vivido, pegando emprestado alguns conceitos do geógrafo brasileiro Milton Santos para repensar o estatuto da cartografia. 
No Capítulo 3, examinaremos as trocas institucionais estabelecidas entre Jorge Glusberg e Walter Zanini. De acordo com a documentação ${ }^{10}$ levantada nos arquivos do MAC USP, esse intercâmbio durou entre 1972 e 1977. É provável que a proximidade entre as duas instituições tenha se dado devido ao mútuo interesse pelas novas plataformas interdisciplinares e multimídias, pelo incentivo às novas tecnologias, sobretudo, o vídeo, e pela rede transnacional de trocas artísticas conceituais. Contudo, é fundamental demarcarmos os diferentes perfis de ambas as gestões e as estratégias definidas por cada uma delas para compreender os meandros desse intercâmbio. Zanini, por exemplo, fomentou a criação de redes alternativas baseadas em relações "de amizade, confiança e afeto", buscando ampliar trabalhos artísticos distantes da lógica do poder e do mercado, "capazes de abrir outros circuitos de intercâmbio e inaugurar cartografias diferentes para mostras, apesar da censura política e das limitações econômicas" (FREIRE, 2012, p. 10). Por sua vez, Glusberg se apoiou em uma ofensiva campanha artística de internacionalização da arte argentina (e por extensão, latino-americana), por meio de um amplo circuito de contatos com instituições estrangeiras que receberam artistas e exposições ligadas ao CAYC, divulgando, assim, seus preceitos da "arte de sistemas". Para auspiciar todas essas frentes, o argentino contou com o amparo financeiro de uma das maiores empresas de iluminação de seu país, a Modulador, da qual era herdeiro. "Glusberg paga os catálogos, a propaganda, os fretes das obras e às vezes os materiais, se os artistas carecem de recursos. Estabelece assim uma densa rede de lealdades profissionais [...] com artistas, arquitetos, urbanistas e críticos" (CANCLINI, 2011, p. 93).

Partindo da compreensão dessas particularidades do perfil de cada gestão institucional, buscaremos analisar quais foram os eixos de diálogo entre Glusberg e Zanini, traçando essa linha de investigação até a vinda do Grupo de los Trece ao MAC USP. Entretanto, essa tentativa de intercâmbio artístico passou por diversos entraves, sobretudo durante a negociação de exposições de conteúdo político mais explícito, como foi o caso de Hacia un perfil del arte latinoamericano, que acabou não sendo exibida no Museu. Lembremos que a conjuntura do período, marcada pela forte repressão militar e pela censura, buscou desativar quaisquer experiências do plano artístico consideradas subversivas. Mas o intercâmbio teve continuidade, promovendo a vinda de artistas do Grupo de los Trece e ligados ao CAYC em

\footnotetext{
${ }^{10}$ Os documentos analisados no arquivo abrangem correspondências trocadas entre Zanini e Glusberg (1972 a 1978); "gacetillas amarelas"; boletins informativos de ambas as instituições e fotografias de exposições do MAC USP no período demarcado por este trabalho.
} 
mostras emblemáticas do Museu, resultantes de práticas experimentais e dos novos media ${ }^{11}$, como a Prospectiva 74 (1974), Poéticas Visuais (1977), Papel e Lápis (1976) e Década de 70 (1976). Esta última foi uma exibição de heliografias organizada por Jorge Glusberg, que fez itinerância pela Cidade do México, Buenos Aires e, por fim, São Paulo. Consideramos que Década de 70 foi uma extensão do programa conceitual promovido pelo CAYC, ao mesmo tempo que representou a consolidação das trocas institucionais entre Glusberg e Zanini. Todos os integrantes do Grupo de los Trece participaram da mostra no MAC USP, junto a uma centena de artistas nacionais e internacionais.

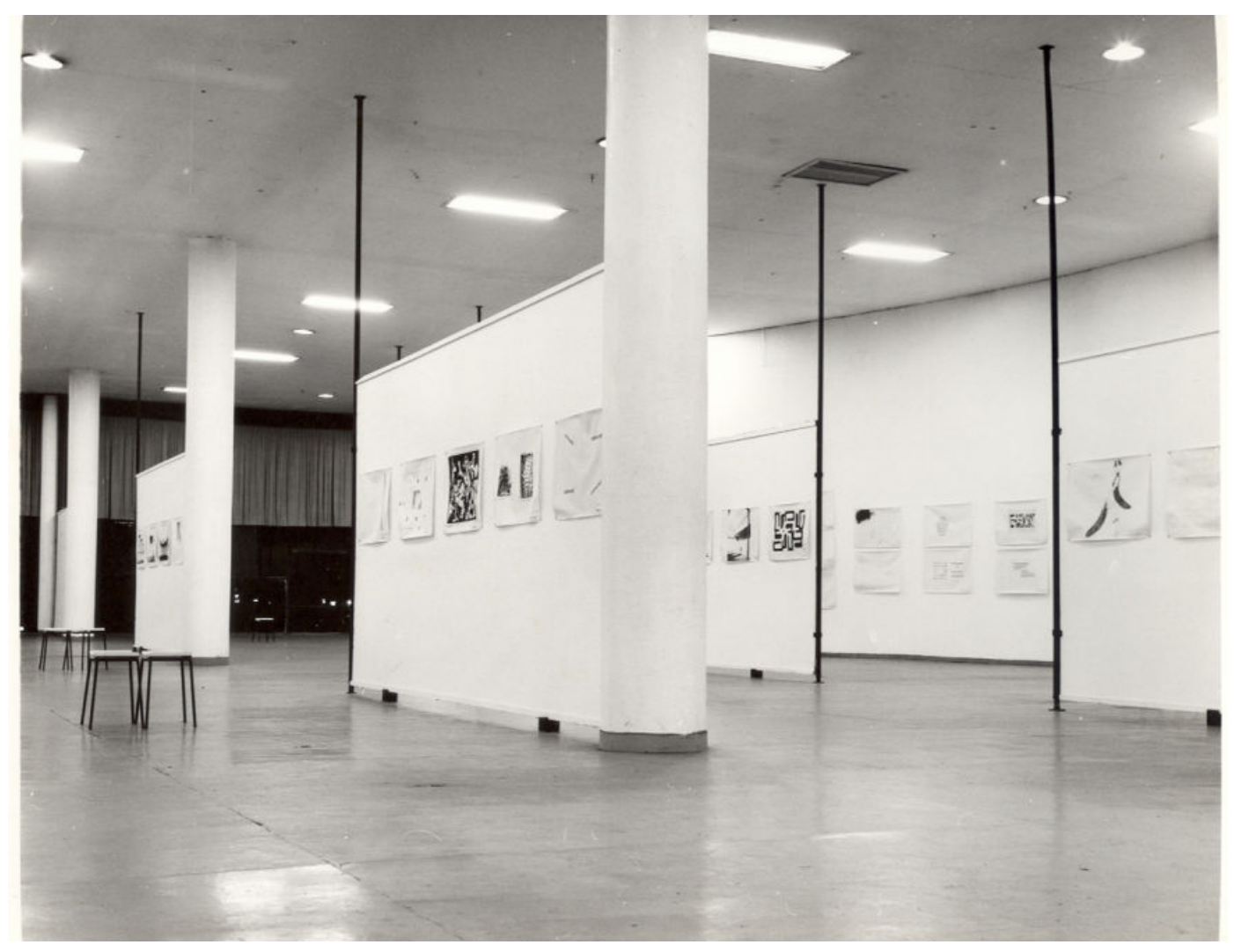

Figura 5 - Vista parcial da mostra Década de 70

Fotógrafo: Gerson Zanini, 1976. Arquivo do MAC USP

\footnotetext{
${ }^{11}$ Termo utilizado por Walter Zanini no catálogo da mostra Prospectiva 74, que se refere às novas linguagens experimentais, para além das categorias tradicionais da pintura e escultura. No fim do texto, Zanini esclarece que as obras realizadas por processo multimedia chegaram ao Museu por via postal. Este será o eixo privilegiado das exposições mencionadas, inclusive a Década de 70. (ZANINI, Walter. Prospectiva 74, cat. exp. São Paulo: Museu de Arte Contemporânea da Universidade de São Paulo - MAC USP, 1974.)
} 
Finalizaremos a trajetória de Jorge Glusberg e dos artistas ligados ao CAYC no Brasil, com uma breve análise de suas presenças na XIV Bienal de São Paulo, em 1977. A instalação Signos em ecossistemas artificiais foi a primeira obra latino-americana a ganhar o Grande Prêmio Itamaraty, gerando polêmica entre os participantes brasileiros, sobretudo pela suposta ligação de Glusberg com a ditadura militar argentina. Não se pode deixar de notar a enorme mobilidade de Glusberg em seu país e no exterior e a coincidência do enrijecimento da ditadura militar com o êxito de seu Centro.

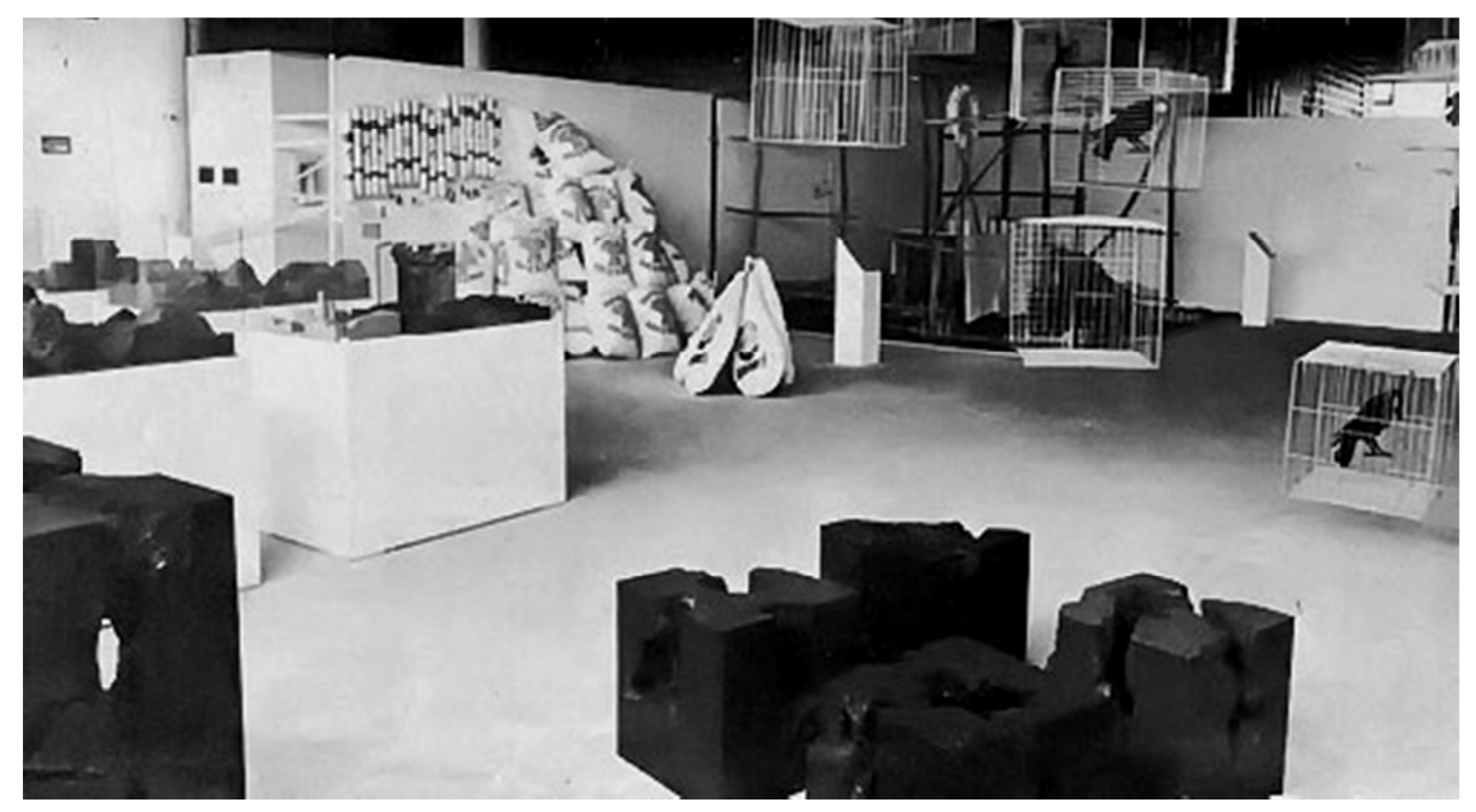

Figura 6 - Vista de parte da instalação Signos em ecossistemas artificiais. XIV Bienal de São Paulo, 1977.

Algumas matérias de jornal da época especularam sobre as possíveis motivações políticas, por tratar-se de um "país de regime amigo". ${ }^{12}$ Sem dúvida, esse prêmio outorgado ao Grupo de los Trece consolidou as estratégias do CAYC, que ao longo da década de 1970, construiu um bem-sucedido programa de articulação, divulgação e legitimação da arte argentina. Em busca da sua liderança continental, "a Argentina 'ganhava' um novo campeonato. E ganhou com a organização, ousadia e dinheiro. Ganhou com a garra e a rapidez das decisões de Jorge Glusberg” (MORAIS, 1979, p. 173).

\footnotetext{
12 In: Premiação da Bienal recebida com protestos. O Estado de S. Paulo. 12 out. 1977, Divisão de Acervo, Documentação e Conservação - Arquivo Multimeios do Centro Cultural São Paulo.
} 
Confrontar os modelos de gestão do MAC USP e CAYC, nos permite compreender essa rica trama de câmbios artísticos e institucionais, possibilitando um outro ângulo sobre esse período no qual sedimentou-se uma nova visualidade. Para a realização desta investigação, foram pesquisados diversos documentos como fotografias, boletins informativos, correspondências, entrevistas, matérias de jornal, catálogos e demais textos em arquivos de Buenos Aires e São Paulo. Cruzando esse núcleo, priorizou-se o estudo das obras do acervo do MAC USP, junto ao levantamento bibliográfico. A partir desses três vetores de pesquisa, tornou-se plausível o estudo dos modelos de institucionalização da arte contemporânea em São Paulo e Buenos Aires, seus eixos de interseção e de desencontros. 


\section{Capítulo 1}

\section{BREVE TÓPICO SOBRE A MODERNIZAÇÃo CULTURAL NA AMÉRICA LATINA}

No final da década de 1950, ocorre na Argentina, sobretudo na capital Buenos Aires, uma série de transformações no cenário cultural resultante de novos projetos econômicos. $\mathrm{O}$ surgimento de políticas de modernização cultural teve o seu marco no chamado desenvolvimentismo econômico, plano que amparou muitos países da América Latina nesse período. O crescimento econômico registrado nessas regiões buscou seu correlato no desenvolvimento e renovação de diferentes áreas culturais.

Esse plano mais dinâmico, pautado nos novos modos de integração capitalista do pósguerra, buscava estimular o desenvolvimento da burguesia industrial vinculada ao capital transnacional. Sabemos que foram estratégias para modernizar a economia, impulsionadas pelo avanço da produção industrial, apoiadas na expansão do mercado interno e no recuo das economias agrárias. ${ }^{13}$ Sobre esse contexto, Néstor García Canclini ${ }^{14}$ realizou um estudo pioneiro na área da sociologia da arte, no qual buscava relacionar o surgimento das vanguardas artísticas argentinas aos novos projetos econômicos, utilizando teorias ligadas a CEPAL (Comissão Econômica para a América Latina e o Caribe) para analisar as consequências geradas pela modernização da economia na área da cultura. $O$ subdesenvolvimento dos países da América Latina, por exemplo, se explicava pela persistência do papel agroexportador, latifundiário, orientado para o exterior, e desse modo era preciso superá-lo para alcançar o fôlego das grandes metrópoles, a fim de romper com o isolamento que o havia impedido de integrar-se ao mercado internacional (CANCLINI, 1979, p. 82),

Además de los avances industriales citados, la vertiginosa expansión demográfica de las grandes ciudades, el impresionante desarrollo de la televisión, la multiplicación de alumnos en la educación superior y otras transformaciones confirmaron las expectativas. El interés por modernizar racionalmente impulsó a los sectores desarrollistas a formar sociólogos, psicólogos y especialistas en todas las disciplinas científicas capaces de

\footnotetext{
${ }^{13}$ Ver Essencial Celso Furtado. São Paulo: Penguin Classics Companhia das Letras, 2013.

${ }^{14}$ Podemos citar: A produção simbólica - Teoria e Metodologia em Sociologia da Arte. Rio de Janeiro: Ed. Civilização Brasileira, 1979; e A socialização da arte - Teoria e prática na América Latina. São Paulo: Ed. Pensamento, 1984.
} 
ordenar del modo más funcional las relaciones sociales. ${ }^{15}$ (CANCLINI, 1984, p. 155)

O forte clima de renovação artística, que buscava romper com a segregação cultural local, contou com o apoio e financiamento de fundações geridas por grupos da nova burguesia industrial argentina e empresas multinacionais. Esse projeto não se apoiou em uma articulação exclusivamente local e pode ser lido dentro de uma conjuntura internacional, marcada pelos conflitos gerados pela Guerra Fria. Vale lembrar que esse período do pós-guerra foi assinalado pela presença constante dos Estados Unidos na região para tratar de assuntos estratégicos que incluía, também, a criação de projetos de modernização cultural, por meio de investimentos estrangeiros estimulados pela Aliança para o Progresso, no princípio da década de 1960. Essa Aliança era uma forma de reviver o programa da Política de Boa Vizinhança, promovido pelo presidente Franklin Roosevelt, para aproximar os países latino-americanos dos interesses políticos norte-americanos, durante a Segunda Guerra Mundial.

Os projetos de renovação cultural não foram somente parte do esforço de uma classe dirigente local a fim de divulgar e ascender a arte argentina. Esse programa foi incluído em um discurso cuja órbita era maior e mais complexa, e encontrou no campo das produções culturais um fundo para apoios econômicos, promoções e estímulos orientados para garantir o caminho de uma transformação política definitiva. Andrea Giunta sustenta que:

[...] el apoyo que este conjunto de instituciones estadounidenses dio al arte latinoamericano debe entenderse también como un instrumento de propaganda orientado a contrarrestar la política cubana hacia los intelectuales latinoamericanos, permanentemente convocados a discutir la cultura de la revolución y cuyas conclusiones se reproducían en las revistas de la intelectualidad de izquierda de todo el continente. ${ }^{16}$ (GIUNTA, 2008, p. 27)

O interesse político no continente, sob o temor do avanço comunista que ameaçava a liberdade na região, promoveu a liberação de verbas pelo Congresso americano para o apoio

\footnotetext{
15 "Além dos avanços industriais citados, a vertiginosa expansão demográfica nas grandes cidades, o impressionante desenvolvimento da televisão, a multiplicação de alunos no ensino superior e outras transformações confirmaram as expectativas. $\mathrm{O}$ interesse por modernizar racionalmente impulsionou os setores desenvolvimentistas a formar sociólogos, psicólogos, especialistas em todas as disciplinas científicas capazes de ordenar de modo mais funcional as relações sociais." (tradução nossa).

16 “[...] o apoio que esse conjunto de instituições norte-americanas deu à arte latino-americana deve ser entendida como um instrumento de propaganda orientado a frear a política cubana dos intelectuais latino-americanos, permanentemente convocados a discutir a cultura da revolução e cujas conclusões eram reproduzidas em publicações ligadas aos movimentos da esquerda.” (tradução nossa).
} 
econômico, que visava alterar a relação de artistas e intelectuais com o pensamento de esquerda.

A União Pan-Americana, a CIA e as multinacionais como Esso, Standart Oil, Shell, Indústrias Kaiser, General Motors, General Electric,

[...] são algumas das empresas que procuraram atualizar a arte latinoamericana relativamente às modas norte-americanas e europeias: oferecem aos artistas plásticos, e em alguns casos também a conjuntos teatrais e musicais, amplas salas de exposição, prêmios e difusão, bienais e jurados de Nova Iorque, Londres e Paris (CANCLINI, 1984, p. 113)

O Museu de Arte Moderna de Nova Iorque (MoMA), seguindo os interesses do grupo Rockfeller, exportou diversas exposições itinerantes que circularam pelo continente, além de buscar acordos que aproximassem as alianças artísticas locais aos padrões reproduzidos pelas instituições norte-americanas e pelo Conselho Internacional do Museu de Arte Moderna de Nova Iorque. Alfred Barr Jr., em sua condição de especialista e diretor das coleções do MoMA, foi comissionado para realizar uma viagem por diversos países da América Latina para adquirir obras representativas da arte moderna local. Como resultado de seu recorrido, Barr organizou a exposição The Latin-American Collection of the Museum of Modern Art, em 1943, com aproximadamente 200 obras de artistas como Emilio Pettoruti, Cândido Portinari, Roberto Matta, Wifredo Lam, Torres García, Diego Rivera, entre outros (SUÁREZ, 1986, p. 76).

Sabemos, também, que o MoMA constituiu-se como instituição emblemática e como espaço privilegiado de exibição de arte moderna. Sua lógica pautada em uma concepção espacial asséptica e atemporal, sem vínculos com o meio externo, auxiliava na construção de uma obra de arte mais individualizada e autorreferente.

Sobre a consolidação ideológica do espaço modernista - o cubo branco, Brian O’Doherty investiga como a arte do século XX foi produzida a partir de preceitos idealizados de um espaço sacralizado análogo às câmaras mortuárias egípcias ou às cavernas paleolíticas de Lascaux, voltando-se à genealogia dessa câmara de exposição eterna. (O'DOHERTY, 2002). São nesses recintos ritualísticos que o autor busca as origens e traça um paralelo com os dispositivos que solidificaram o discurso de eternidade da obra artística, tal como difundira o MoMA. 
Nessa perspectiva, a arte abstrata enquadrou-se como discurso privilegiado desse espaço sacralizado. A batalha travada nos primeiros anos da Guerra Fria, a partir das estratégias de exportação de linguagens artísticas (arte abstrata) e modelos expositivos (cubo branco), se deu, de acordo com Canclini (1979, p. 85), por meio da difusão de uma "experimentação formal aparentemente despolitizada" e "sobretudo o expressionismo abstrato, como alternativa ao realismo social". A imposição de um estilo único e legítimo construiu a retórica do abstracionismo como uma ferramenta poderosa que simbolizava a supremacia norte-americana, e sob esse ponto de vista, esquematizava um jogo de oposição que representava o êxito do capitalismo versus o realismo de matriz comunista.

As políticas de visibilidade do modernismo se pautaram na ênfase conferida à planaridade, e desse modo a superfície plana tornou-se uma competência única e privilegiada da arte pictórica. "Por ser a planaridade a única condição que a pintura não partilhava com nenhuma outra arte, a pintura modernista se voltou para a planaridade e para mais nada". ${ }^{17} \mathrm{De}$ acordo com a visão essencialista do crítico norte-americano Clement Greenberg, a arte prémoderna havia dissimulado os meios, usando a arte para ocultar a própria arte. E dentro de uma linha evolutiva e linear, o modernismo substituiria essa narrativa realista e vasariana, usando a arte para chamar a atenção para o que era de competência única e exclusiva da arte. Assim sendo, se debruçaria sobre os elementos constitutivos da pintura - a linha, a forma e a superfície plana, para evidenciar os seus aspectos primordiais. ${ }^{18}$ Em seu primeiro ensaio publicado, Vanguarda e Kitsch, de 1939, Greenberg já anunciava a "busca do absoluto", da "arte pela arte", delineando os contornos de sua crítica ferrenha pela arte abstrata.

$\mathrm{Na}$ chave da "transformação de mitos literários em mitos literais" (O’DOHERTY, 2002, p. 14), pureza significava autodefinição e, desse modo, era prioridade do artista dispensar ideias que contaminassem a arte com demandas ideológicas da sociedade. Quer dizer, abolir quaisquer conteúdos sociais, principalmente os que tomaram como modelo o realismo social do muralismo mexicano.

\footnotetext{
${ }^{17}$ GREENBERG, Clement. Pintura modernista. In: COTRIM, Cecília; FERREIRA, Glória (Org.). Clement Greenberg e o debate crítico. Rio de Janeiro: Jorge Zahar Editor, 1997, p. 103.

${ }^{18}$ Vale lembrar que esses paradigmas já vinham sendo discutidos desde o final do século XIX, como atesta a célebre frase de Maurice Denis: "Uma pintura, antes de ser um cavalo de guerra, uma mulher nua ou qualquer anedota, é essencialmente uma superfície plana coberta com cores numa determinada ordem". Posteriormente, Malevich, num texto de 1915, observou: "O que tem um valor em si na criação pictórica é a cor e a fatura é a essência pictórica, mas essa essência sempre foi destruída pelo tema... Para se encaminhar à autonomia da cor, para a hegemonia das formas pictóricas que constituem exclusivamente seu próprio fim em relação ao conteúdo e aos objetos...”. Maurice Denis e Kasimir Malevich apud NAVES, Rodrigo. O vento e o moinho - ensaios sobre arte moderna e contemporânea. São Paulo: Companhia das Letras, 2007. p. 151.
} 
No processo de deslocamento do eixo artístico de Paris para Nova Iorque, e na constituição de uma nova versão da história da arte, Clement Greenberg teve um papel decisivo de consolidar o prestígio do expressionismo abstrato no relato da arte moderna. $\mathrm{E}$ essa estabilidade alcançada só podia se dar por meio de uma linguagem de valor universalizante, capaz de multiplicar-se e expandir-se:

[...] el dominio total del arte abstracto, capaz, por su repertorio estandarizado de formas y colores, de borrar las diferencias nacionales, junto al uso de nuevos materiales que también inciden en la unificación del lenguaje (como el cemento armado, los plásticos, las anilinas, "materiales internacionales, sin color local"), son otros tantos elementos propicios para la urgente $\mathrm{y}, \mathrm{al}$ parecer, inevitable, internacionalización del arte argentino. (GIUNTA, 2008, p. 102) ${ }^{19}$

Esse pacote exportado para o lado debaixo do equador estava de acordo "com as exigências da casta ou do grupo que compartilha tal sensibilidade [...] promovendo um sentido de realidade única e de seu ponto de vista", (O’DOHERTY, 2002, p. 22) dando continuidade, por sua vez, à consolidação de tal estrutura de poder. Nesse paralelo entre arte e poder, pode-se observar que a arte abstrata foi eleita como a sensibilidade máxima e foi beneficiada por ações institucionais, adentrando no território latino-americano no momento em que o continente assumia novas configurações na geopolítica da Guerra Fria. Walter Mignolo $^{20}$ auxilia a interpretação crítica dos fenômenos culturais e do legado colonial, mais especificamente, da configuração do novo desenho imperial após 1945. A disputa entre espaços geográficos e localizações epistemológicas, de acordo com o autor, permite refletir sobre a categoria "terceiro mundo", no momento em que os Estados Unidos alcançaram a hegemonia mundial e rearticularam as áreas geográficas em relação ao conhecimento. Nesse jogo, conduziram a produção e distribuição de conhecimento, e o controle do desenvolvimento e modernização do terceiro mundo (nomenclatura que abrange a América Latina), articulando categorias geoculturais que organizaram a distribuição do poder em termos “geopistemológicos" (MIGNOLO, 1998).

\footnotetext{
19 “[...] o domínio total da arte abstrata, capaz, por seu repertório estandardizado de formas e cores, de borrar as diferenças nacionais, junto ao uso de novos materiais que também incidem na unificação da linguagem (como o cimento armado, os plásticos, anilinas, "materiais internacionais, sem a cor local"), são outros tantos elementos propícios para a urgente e, ao que parece, inevitável, internacionalização da arte argentina." (tradução nossa).

${ }^{20}$ MIGNOLO, Walter. Espacios geograficos y localizaciones epistemologicas: la ratio entre la localización geografica y la subalternización de conocimientos, 1995. In: Estudios - Revista de Investigaciones Literarias y Culturales. Caracas, v.6, n.11, jan. 1998.
} 
É válido ressaltar que a diplomacia cultural mediada pelos EUA se inscreve nessa nova articulação geográfica e epistêmica, formando uma trama complexa na consolidação de uma nova ordem discursiva. As alianças que permitiram o financiamento tinham como contrapartida a renovação política e cultural, a afirmação de uma imagem positiva de um país disposto a crescer e, sobretudo, aberto a acordos e pactos políticos. Seguindo o pensamento de Mignolo, essa conjuntura geopolítica primava pela distribuição e estabilização de novos conhecimentos, e nesse contexto, num primeiro momento (entre as décadas de 1940 e 1950), os movimentos derivados do abstracionismo representavam a ordem discursiva do campo artístico, de modo a simbolizar inovação e modernização. Veremos a seguir como esse projeto se desdobrou, e por meio de quais linguagens artísticas e políticas institucionais foi promovido.

\section{1- Preâmbulos Para Alguns estudos de caso}

\subsection{1 - InTERCÂMbios ARTísticos ENTRE Brasil E Argentina - BIENAL E MAMS}

Sabemos que a nova conjuntura política do pós-guerra teve suas traduções culturais, e as artes plásticas, assim como a fundação de um aparato museológico moderno, foram peças-chave desse processo. A arte abstrata como linguagem paradigmática desse raio modernizador resultou em um fator fundamental na militância pela abertura dos novos museus de arte moderna.

O recorte desta pesquisa buscará analisar de maneira breve como as primeiras instituições modernas brasileiras e argentinas, no início dos anos de 1950, sustentaram a imagem inovadora de seu projeto por meio do estímulo às tendências abstratas. $\mathrm{O}$ museu se apresentava na condição de produtor de arte moderna, que nesse momento era definida pela arte abstrata. A alteração dessa tradição visual, antes vinculada com a identidade do nacional, após os modernismos dos anos de 1920, evidenciou um modo de indicar a atualidade das instituições artísticas nacionais numa chave internacionalista. A implantação dos MAMs reivindicava o internacionalismo, "assim revelando o nacionalismo estreito e discriminador, o que é, sem dúvida, exponencial" (LOURENÇO, 1999, p. 104). Contudo, é válido ressaltar que 
não foi o marco do expressionismo abstrato norte-americano que se consolidou do lado de cá, mas da abstração geométrica vinculada ao concretismo suíço, alemão e holandês, como observaremos adiante, manifestando uma "vocação construtiva"21 de nossos artistas.

A criação dos museus paulistanos e cariocas e a inauguração das primeiras Bienais de São Paulo introduziram o Brasil em um novo patamar na trama regional, tornando-o, para os vizinhos, uma vitrine internacional da renovação das linguagens artísticas.

\begin{abstract}
A implantação dos MAMs, após a Segunda Guerra Mundial, colabora para fomentar modificações nas condições culturais e, também, coaduna-se com alguns ideais político-econômicos realizados ao fenômeno da metropolização, industrialização, desenvolvimentismo e alianças com os Estados Unidos. Nesse panorama, São Paulo assume papel ímpar pela concentração de atividades econômicas, em especial na questão industrial, enquadrando-se a abertura do MAM como parte explicitadora de uma imagem que se almeja atingir. (LOURENÇO, 1999, p.103)
\end{abstract}

Um novo mecenato proveniente de setores de uma burguesia em ascensão vinculada à indústria buscava projetar-se economicamente por meio de iniciativas culturais. De acordo com Aracy Amaral, desde a década de 1930 estava no ar a ideia de se construir um museu moderno, que fora possível com os esforços de Sérgio Milliet e suas conexões com Matarazzo e Nelson Rockfeller (AMARAL, 2006, p. 240). Embora com perfis institucionais distintos, o MASP e o MAM SP disputaram a supremacia cultural de São Paulo. O primeiro fora fundado em 1947, pelo magnata da área de comunicação Assis Chateaubriand e contou com a consultoria artística do marchand italiano Pietro Maria Bardi. No ano seguinte o MAM SP fora inaugurado sob o comando do industrial Francisco Matarazzo Sobrinho - o Ciccillo -, e tinha como diretor artístico, o crítico belga León Degand. Ambas instituições contaram com o apoio de Rockfeller.

Embora o modelo de um museu de arte moderna fosse o de Nova Iorque, a estruturação do MAM SP, realizada por Degand, revelava intenções mais ambiciosas para além da renovação dos códigos artísticos. Buscava-se constituir uma entidade para as próximas gerações, um museu didático formador de público que contaria, também, com cinemateca, cursos de arte, palestras e debates, com a abertura total para as novas tendências artísticas (AMARAL, 2006, p. 251).

\footnotetext{
${ }^{21}$ Ver MORAIS, Frederico. Artes plásticas na América Latina: do transe ao transitório. Rio de Janeiro: Ed. Civilização Brasileira, 1979.
} 
A exposição inaugural do MAM SP, Do Figurativismo ao Abstracionismo, de 1949, abriu o circuito de mostras do novo Museu e consolidou institucionalmente a inserção da arte abstrata como modelo hegemônico. O internacionalismo aberto por essa tendência teria repercussões mais amplas nos anos seguintes, com a abertura da I Bienal do Museu de Arte Moderna de São Paulo, dois anos mais tarde. Essas iniciativas que visavam projetar a arte brasileira, estabilizava ou excluía nomes e tendências da história da arte, tornando-se um mecanismo fundamental para a formação e ampliação dos acervos museológicos (LOURENÇO, 1999, p. 113). A seleção das obras feita por León Degand privilegiou as escolas francesas, com a presença de artistas do Cercle et Carré (notando a ausência do uruguaio Torres-García), Abstraction-Créactione e Réalités Nouvelles ${ }^{22}$. A representação nacional contou apenas com os convidados Waldemar Cordeiro, Samsor Flexor e Cícero Dias. O arco temporal indicado no título da exposição - Do ao - evidenciava uma leitura progressiva de Degand, na qual a abstração representava o ápice da linha evolutiva dos movimentos artísticos iniciada com a figuração.

A relação entre o meio artístico brasileiro e argentino foi gradualmente intensificada ao longo desses anos. Alguns fatores evidenciaram o interesse por esse intercâmbio. Podemos citar a articulação dos novos projetos institucionais brasileiros que transformaram a trama cultural regional, tendo como ponta de lança a arte abstrata como fator dessa renovação. ${ }^{23} \mathrm{~A}$ pesquisadora María Amalia García (2008) estudou o panorama artístico argentino desse período a partir das relações com o Brasil, indagando por meio de quais canais foi possível realizar esse intercâmbio e como o campo cultural portenho reagiu frente à projeção do novo aparato museológico paulistano.

A exposição de Degand é um dos eixos de articulação entre os dois países. Do Figurativismo ao Abstracionismo também inaugurou outra instituição de caráter modernizador na Argentina. Sob o título El Arte Abstrato, foram abertas as atividades do Instituto de Arte Moderno de Buenos Aires (IAM), em 1949. Amalia García (2008) demonstra como os interesses do fundador do IAM, Marcelo De Ridder, se aproximaram das novas apostas paulistanas, como comprova na análise de diversas cartas trocadas entre o argentino e Ciccillo. A exposição era praticamente a mesma da versão brasileira, salvo algumas exceções, e fora um sucesso de público. Vale ressaltar que as propostas abstracionistas já circulavam

\footnotetext{
${ }^{22}$ Ver Do Figurativismo ao Abstracionismo, catálogo da exposição. São Paulo: Museu de Arte Moderna, 1949.

${ }^{23}$ GARCÍA, María Amália. Abstracción entre Argentina y Brasil: inscripción regional e interconexiones del arte concreto (1944-1960). Tese de Doutorado. Universidade de Buenos Aires, Buenos Aires, 2008.
} 
pelo circuito artístico e pela crítica portenha há alguns anos, lembrando a importância das tendências concreto-construtivas advindas da revista Arturo (1944) que se desdobraram nos movimentos Madi e Asociación Arte Concreto-Invención. ${ }^{24}$

No artigo La construcción del arte abstracto, Amalia García (2004) nos mostra que De Ridder manteve uma série de negociações com o MASP para tentar incluir a mostra de Max Bill, exposta no museu paulista em 1951, na programação de seu novo instituto. Problemas econômicos e de alfândega impossibilitaram a itinerância da exposição, mas ficou claro que a instituição portenha demonstrava interesse no programa modernizador dos novos museus paulistanos.

A intensidade da movimentação artística em São Paulo, além da vinda de Degand e sua batalha pela arte abstrata, gerando debates fervorosos no circuito brasileiro ${ }^{25}$, apresentou mostras emblemáticas para as gerações seguintes. Nos seus primeiros anos, o MASP organizou as exposições de Max Bill e Alexander Calder e trouxe o crítico argentino Jorge Romero Brest para realizar uma série de seis conferências intitulada Como um sul-americano vê o movimento artístico contemporâneo da Europa.

Em 1948, dois anos antes do ciclo de conferências, Romero Brest e P. M. Bardi iniciaram uma troca de cartas, cujo exame mostra o interesse do argentino em conhecer o Brasil, em especial São Paulo, "ciudad en la que según noticias se esta desarrollando un movimento de importancia"26. De acordo com as correspondências, sabemos que Brest buscava incluir devida atenção aos temas ligados à arte abstrata, "con certo carácter polémico en cuanto a la defensa y afirmación de arte abstracto" 27 .

\footnotetext{
${ }^{24}$ Ver PERAZZO, Nelly. Las vanguardias constructivas en la Argentina. In: BELLUZZO, Ana Maria (Org.). Modernidade: vanguardas artísticas na América Latina. São Paulo: Editora Unesp, 1990.

${ }^{25}$ Sobre o debate envolvendo arte abstrata e figurativa, ver AMARAL, Aracy: Realismo versus abstracionismo e o confronto com a Bienal. Em: Arte para quê? A preocupação social na arte brasileira. 1930-1970. São Paulo: Nobel, 1984.

${ }^{26}$ "Cidade na qual, segundo notícias, está desenvolvendo um movimento de importância." (tradução nossa). Correspondência de J.R. Brest a P.M.Bardi. Carta sem data. Pasta 12, Caixa 3. Arquivo MASP.

27 "Com certo caráter polêmico na defesa e afirmação da arte abstrata." (tradução nossa). Correspondência de J.R. Brest a P.M.Bardi. 18 set. 1950. Pasta 12, Caixa 3. Arquivo MASP.
} 


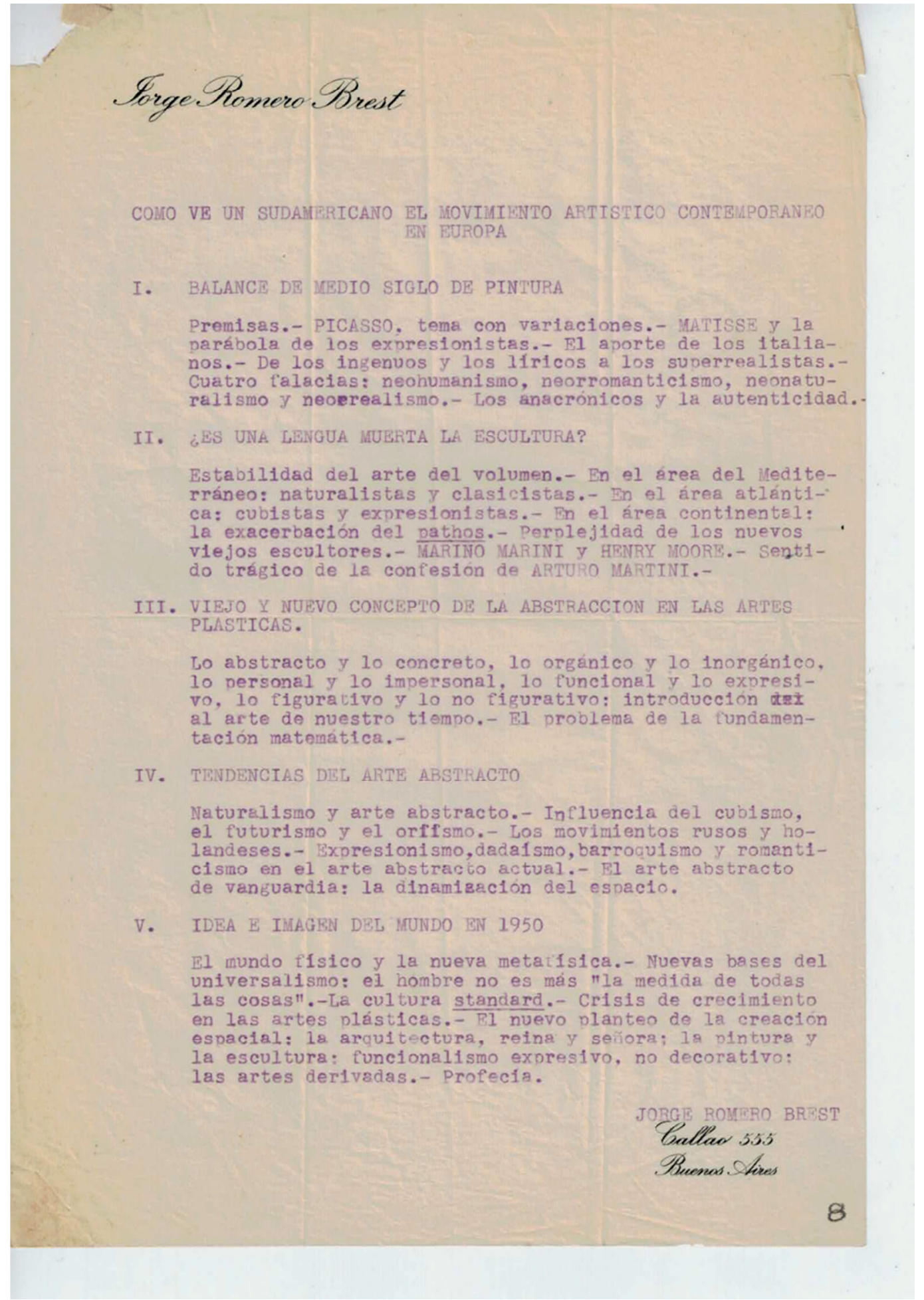

Figura 7 - Como ve un sudamericano el movimento artístico contemporaneo em Europa Jorge Romero Brest, Arquivo MASP. 
Os jornais da época anunciaram a presença do crítico argentino e divulgaram os distintos temas abordados nas conferências. Por meio de Aracy Amaral, damos conta da repercussão gerada pela presença de Brest na cena artística do período. A autora incluiu uma das matérias que circularam em 1950, A arquitetura é a grande arte de nosso tempo, no catálogo da exposição Projeto Construtivo Brasileiro na Arte (1950-1962) ${ }^{28}$, vinculando as conferências ao surgimento da arte concreta brasileira, especificamente os artistas que iriam se reunir em torno do Grupo Ruptura (1952), base do concretismo de São Paulo, e do Grupo Frente (1953), base do neoconcretismo carioca.

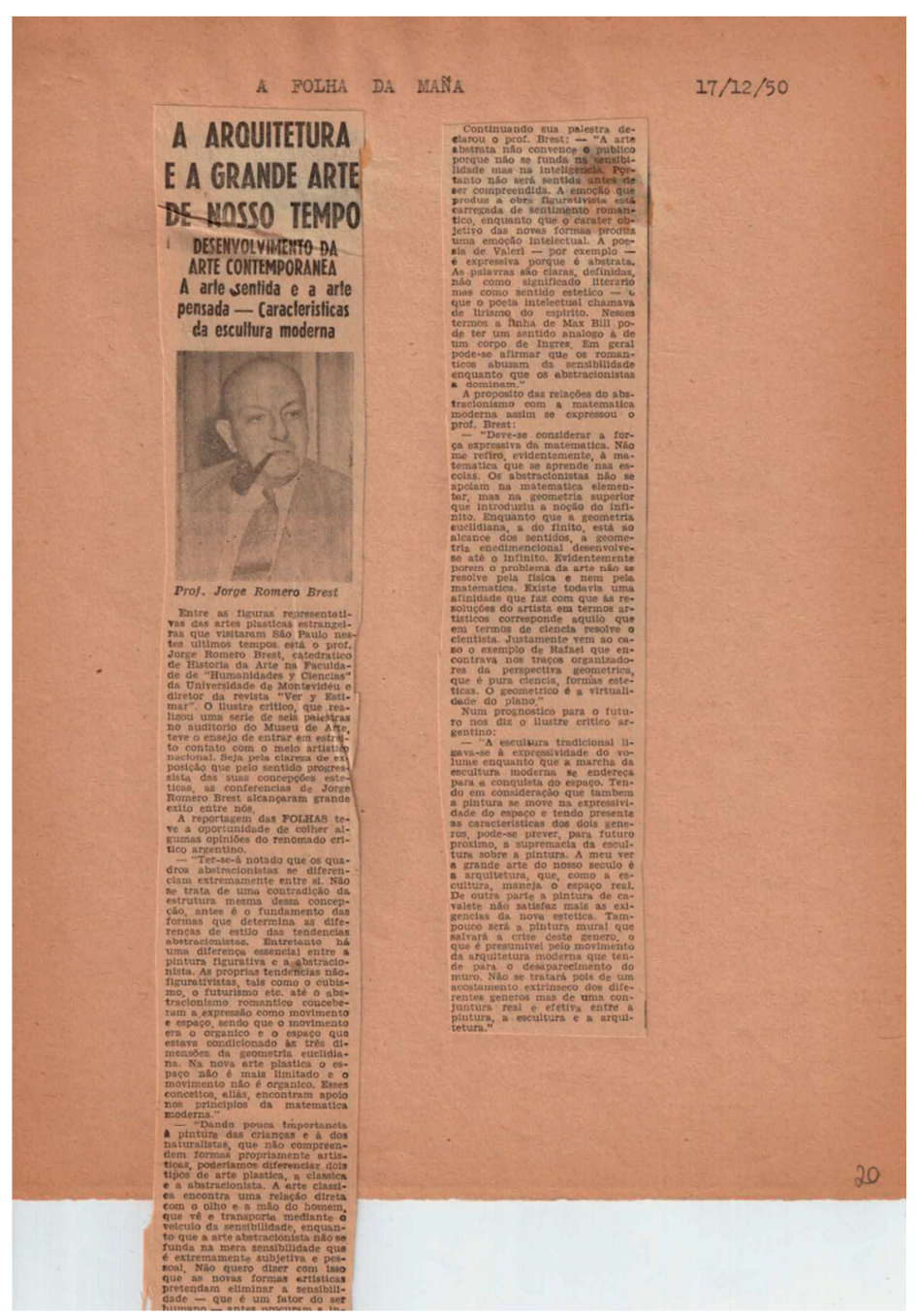

Figura 8 - A arquitetura é a grande arte do nosso tempo Folha da Manhã. 17 dez. 1950. Arquivo MASP.

\footnotetext{
${ }^{28}$ AMARAL, Aracy (Coord.). Projeto construtivo brasileiro na arte (1950-1962), catálogo de exposição. Rio de Janeiro: Museu de Arte Moderna; São Paulo: Pinacoteca do Estado, 1977, p. 98.
} 
Nessa matéria, Romero Brest dava um prognóstico para o futuro:

A meu ver a grande arte do nosso tempo é a arquitetura, que, como a escultura maneja o espaço real. De outra parte a pintura de cavalete não satisfaz mais as exigências da nova estética. Tampouco será a pintura mural que salvará a crise deste gênero, o que é presumível pelo movimento da arquitetura moderna que tende para o desaparecimento do muro. Não se tratará pois de um acostamento extrínseco dos diferentes gêneros mas de uma conjuntura real e efetiva entre a pintura, a escultura e a arquitetura. ${ }^{29}$

A fala visionária de Brest se relaciona com algumas concepções que foram caras à arte brasileira, como a síntese das artes ou arte-total, articulando o interesse despertado dos artistas concretos pela arquitetura, por exemplo. A reivindicação pelo espaço real (próprio da arquitetura) e o rompimento com a bidimensionalidade na pintura e com o volume na escultura, indicariam os caminhos para essa síntese.

Romero Brest ainda esteve presente como jurado de três bienais (1951, 1953 e 1961), além de organizar o envio da importante mostra sobre arte concreta argentina ao MAM RJ, em 1953. Também compartilhava o interesse pelas propostas de Max Bill, outro eixo de interseção entre Brasil e Argentina, publicando artigos do artista suíço na revista sob sua direção, Ver y Estimar ${ }^{30}$.

Sabemos do impacto que a escultura Unidade tripartida de Max Bill, grande prêmio da I Bienal, de 1951, causou no panorama artístico latino-americano no decorrer da década de 1950. Tomás Maldonado, artista concreto argentino, outra figura fundamental que estaria presente na II Bienal de São Paulo e que estabeleceu contato com os concretos paulistanos, escrevera sobre as esculturas de Bill: "hablaban a la sensibilidad en un idioma hasta ahora nunca escuchado". Unidade Tripartida era uma das obras de "mayor temperatura lírica de la escultura contemporánea”31 (MALDONADO apud GARCÍA, 2008, p. 35). Leonor Amarante (1989, p. 24-25) nos conta que Romero Brest disse ter sido o responsável pela premiação de Max Bill na I Bienal:

\footnotetext{
29 “A arquitetura é a grande arte do nosso tempo”. Folha da Manhã, São Paulo, 17 dez. 1950. Pasta 12, Caixa 3. Arquivo MASP.

${ }^{30}$ BILL, Max: O pensamento matemático na arte de nosso tempo. Ver y Estimar, n. 17, maio 1950.

31 "falavam da sensibilidade de um idioma até agora nunca ouvido." [...] "maior temperatura lírica da escultura contemporânea." (tradução nossa).
} 
Chegando ao Trianon, o júri já trabalhava há dias e então pedi algumas horas para ver as obras. [...] Encontrei uma obra sensacional, Unidade tripartida. Voltei correndo ao júri e disse: Senhores, acabo de descobrir um trabalho que deve ser, sem dúvida, premiado. [...] Mas deu para perceber que nenhum deles tinha visto a obra.

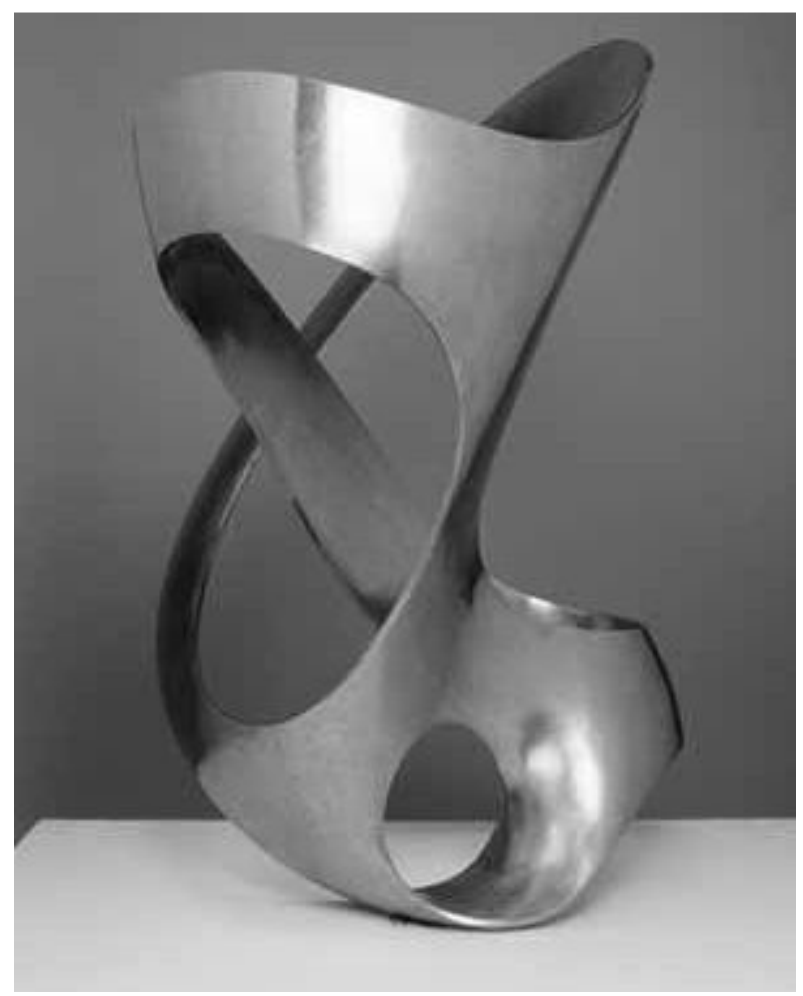

Figura 9: Unidade tripartida, Max Bill, 1948-1949 Aço inoxidável, 114,0 x 88,3 x 98,2 cm - Coleção MAC USP.

A estrutura básica da escultura era a fita de Möebius, uma linha infinita que traduzia a investigação rigorosa do artista suíço aos princípios de uma arte científica com fundamentação matemática e estruturas geométricas. Conforme escreveu Bill, "o elemento de toda obra plástica é a geometria, relação de posições sobre o plano e o espaço" ${ }^{\text {,32. Seus }}$ escritos circularam em diversas publicações portenhas e Maldonado, por exemplo, publicou o livro Max Bill $^{33}$, em 1955. Um ano antes, o concreto argentino viajou à Ulm (Alemanha), a convite do próprio Bill, para ser professor da Escola Superior da Forma, onde seria posteriormente diretor. O artista suíço e todo seu suporte teórico auxiliaram as propostas dos diversos grupos concretos argentinos que trabalhavam de diferentes modos, a partir de alguns

\footnotetext{
32 BILL, Max. O pensamento matemático na arte do nosso tempo. In: AMARAL, Aracy (Coord.). Projeto construtivo brasileiro na arte (1950-1962). Rio de Janeiro, Museu de Arte Moderna; São Paulo, Pinacoteca do Estado. 1977, p. 98

${ }^{33}$ Ver MALDONADO, Tomás. Max Bill. Buenos Aires: Nueva Visión, 1955.
} 
pontos fundamentais: a ruptura com a figuração e afirmação dos valores do concretismo, a preocupação com a inteligibilidade das obras e o desejo de transformação da realidade por meio de uma arte comprometida com o social (PERAZZO, 1990, p.162).

A penetração das ideologias construtivas na América Latina esteve ligada aos projetos desenvolvimentistas do continente. De acordo com Ronaldo Brito, "encaixavam-se com perfeição os projetos reformistas e aceleradores dos países [...] e serviram, até certo ponto, como agentes de libertação nacional frente ao domínio da cultura europeia, ao mesmo tempo em que significavam uma inevitável dependência a ela" (1977, p. 303). O "sonho suíço" de transformação social integrava-se ao esforço de superação do subdesenvolvimento e do atraso econômico e cultural típicos de nossos países, por meio de uma arte disposta à ordem racional, capaz de estabelecer uma dinâmica progressista no campo cultural (1977, p. 304).

O certo é que nas décadas de 40-50 há uma coincidência de objetivos entre as ideologias construtivas no plano cultural, o desenvolvimentismo no plano econômico e as alianças culturais no plano político. No Brasil, por exemplo, a década construtiva por excelência é a do desenvolvimentismo [...] e do processo econômico denominado 'substituição de importações'. Ao rápido crescimento e modernização das grandes cidades corresponde também a ambição de nossa burguesia superar a condição, como país, de mero exportador de matérias-primas minerais, de país agroexportador. Este esforço modernizador e o crescimento demográfico das cidades vão gerar novas formas culturais (MORAIS, 1979, p. 88).

É incontestável que a Bienal tenha se constituído como vitrine de diversas tendências da arte argentina a partir da década de 1950. O internacionalismo aberto pelas tendências abstratas, que dominou as primeiras Bienais, e a consolidação de São Paulo como novo centro artístico de grande visibilidade internacional substituíam a antiga supremacia cultural argentina. A Bienal pôs em funcionamento uma complexa maquinaria de gestão cultural, redesenhando uma nova geografia para o mundo das artes (GARCÍA, 2004, p.17). As Bienais de São Paulo tinham como missão divulgar a arte brasileira em momento de privilegiada atenção internacional; apresentar a arte estrangeira para o público local; representar simbolicamente a cidade de São Paulo e o mecenato de seu empresariado; e servir como articulação internacional de críticos envolvidos na formulação das representações nacionais (HERKENHOFF, 2001, p. 118-119). 
Buscando sair do isolamento cultural da primeira fase do peronismo (1946-1952), que se encontrava à margem dos novos códigos estéticos que haviam sido patrocinados pela nova burguesia econômica e cultural paulistana, diversos atores culturais argentinos procuraram renovar a programação de seus aparatos institucionais. Analisaremos adiante algumas das estratégias escolhidas para a renovação das instituições argentinas, que seguirá ao longo da década de 1960 e que terá como ápice a abertura do Centro de Artes Visuais (CAV), do Instituto Torcuato Di Tella, conduzida por Romero Brest. Esse grande empreendimento cultural tinha o perfil mais próximo das iniciativas paulistanas de Ciccillo e Chateaubriand e deu impulso à internacionalização da arte argentina.

\subsection{2 - OUTRAS REFLEXÕES SOBRE O CASO ARGENTINO}

Sobre os processos de modernização no campo cultural, Longoni e Mestman (2008, p. 41) observam a ocorrência de três tendências que foram desenvolvidas no centro dessas novas ações. A primeira se deu por meio da criação de novas instituições ou a renovação do programa das já existentes; a segunda, pela emergência de novos produtores culturais, em sua maioria jovens, que atualizaram radicalmente as disciplinas e introduziram novas estéticas; e a terceira, por meio do surgimento de um novo público, mais amplo e consumidor de novidades.

Fruto de um intenso crescimento dos meios de comunicação de massa, circunscreve-se nessa tendência o boom da literatura latino-americana, com a consagração de escritores, assim como o aumento considerável do mercado editorial. São anos da eclosão do cineclubismo, do teatro experimental e de revistas especializadas que serviram como espaço de debates e polêmicas.

Nas políticas de modernização cultural, voltadas para o contexto argentino, pode-se identificar um antecedente importante no âmbito da difusão de crítica de arte, por meio da associação Ver y Estimar, inaugurada em 1948 e dirigida por Jorge Romero Brest. Por meio do ensaio como gênero privilegiado, analisaram-se obras, exposições nacionais e internacionais. Houve uma intensa busca pela atualização bibliográfica como forma de propor a reflexão sobre as novas perspectivas artísticas (GIUNTA, COSTA, 2005, p. 21). A revista 
circulou até 1955 e contribuiu para a difusão da arte moderna e para a formação de um público consumidor de arte.

$\mathrm{Na}$ década seguinte tornou-se comum a circulação de semanários aos moldes do Times, que difundiam, segundo Canclini,

com estilo modernizado, os novos produtos introduzidos no mercado, os projetos políticos da burguesia industrial e os critérios estéticos das vanguardas internacionais: a revista argentina que iniciou essa corrente, Primera Plana, surgiu em 1962 (CANCLINI, 1979, p. 86).

Essa efervescência refletiu nas ações e renovações institucionais do Museu Nacional de Belas Artes (MNBA) de Buenos Aires, espaço de consagração artística mais importante do país. Pode-se datar o início dessas mudanças com a gestão de Jorge Romero Brest, a partir de 1955. O então diretor do MNBA pôde dar continuidade ao seu programa de atualização artística e juízo estético pautado numa concepção cronológica de história da arte moderna, o qual praticara anos antes em Ver y Estimar. A nova pauta museológica favoreceu o aumento do patrimônio com a aquisição de obras contemporâneas ao acervo; a publicação de catálogos e o estímulo à área pedagógica, visando à formação e ao refinamento estético das futuras gerações (GIUNTA, 2008, p. 73). Além disso, houve um aumento no número das mostras de artistas contemporâneos de diversas nacionalidades.

O Museu também foi sede do Prêmio Instituto Torcuato Di Tella, entre 1960 e 1962, trazendo artistas internacionais e jurados de renome, como Giulio Carlo Argan e Lionello Venturi $^{34}$. Nota-se, com esse tipo de iniciativa, uma das estratégias centrais de Romero Brest: dar impulso a um projeto internacionalista, que seria promovido com mais intensidade em sua gerência do Centro de Artes Visuais do Instituto Di Tella, a partir de 1963. Brest define os primeiros contornos desse projeto, rompendo com o isolamento cultural de Buenos Aires ao propor a vinda de exposições de fora, cujo intuito era atualizar a arte local e aproximar os artistas da agenda internacional.

Um país em pleno desenvolvimento, cujo desempenho favorável se dava às custas da expansão do mercado interno, com respaldo do crescimento econômico, devia ter seu equivalente no âmbito cultural. A ambição de chegar ao ranking das grandes metrópoles, no

\footnotetext{
${ }^{34}$ Argan participou do júri de seleção do Prêmio Nacional e Internacional ITDT, ao lado de James Johnson Sweeney e Romero Brest, em 1962. Lionello Venturi já era uma figura presente na cena artística argentina desde a década anterior, quando prestou consultoria para a aquisição de obras da coleção de Don Torcuato Di Tella, e após a sua morte, seguiu prestando serviços ao filho Guido Di Tella.
} 
terreno da cultura, exigia a fundação de um órgão modernizador. Essa urgência contribuiu para o projeto da construção do Museu de Arte Moderna (MAM de Buenos Aires). Rafael Squirru, escritor e crítico de arte argentino, assinou o decreto da fundação do MAM, que funcionou no papel durante anos até a inauguração oficial de sua sede, em 1960. Antes de ser fundado, o Museu organizou dezenas de exposições em diversas galerias privadas da cidade, divulgando uma gama ampla de linguagens que ia do abstracionismo informal, geométrico ao figurativo e concreto.

No ano de sua inauguração, abrigado nas salas do Teatro Municipal San Martín, realiza-se uma importante mostra coletiva que incluía as expressões mais atuais da arte moderna produzida na Argentina. A Primera Exposición Internacional de Arte Moderno abrangia uma centena de artistas locais e estrangeiros. "Para esta megamuestra, Squirru logra, incluso, que el Museo de Arte Moderno de Nueva York envíe obras de Pollock, de Kooning, Kline y Tobey" (LONGONI, MESTMAN, 2008, p. 47) ${ }^{35}$. A intersecção de artistas argentinos com os grandes nomes da arte internacional serviu de modelo para propostas expositivas futuras que seriam realizadas no Instituto Di Tella, principalmente com os Prêmios Nacionais e Internacionais, a partir de 1960. A premiação, como estratégia de consagração de legitimação de artistas e tendências, fora amplamente empregada. Os mais notórios foram os do Di Tella, mencionados acima; Prêmio Ver y Estimar; Bienal Americana de Córdoba (patrocinada pelas indústrias Kaiser); e o Prêmio Braque, auspiciado pela Embaixada da França.

A renovação dos programas institucionais oficiais, o crescimento do mercado editorial, da atividade universitária, junto à ampliação da oferta artística e do público se somavam à ação do Fundo Nacional das Artes que, desde 1958, havia se estabelecido como um novo regime dentro das políticas estatais de promoção da cultura.

Nessa conjuntura, o Estado havia expressado o seu apoio à cultura, no entanto, esse apoio simbolizava apenas um estímulo à renovação e à liberdade institucional de seus gestores, e não, de fato, um financiamento adequado e efetivo para deflagrar mudanças a curto prazo no interior das instituições. Sem o apoio financeiro estatal, ficou claro que "Los organismos capaces de llevar adelante la transformación que el campo artístico necesitaba no serían aquellas dependientes del Estado, sino las nuevas fundaciones e

\footnotetext{
${ }^{35}$ Para esta mega exposição, Squirru consegue, inclusive, que o MoMA envie obras de Pollock, de Kooning, Kline e Tobey. Tradução nossa.
} 
instituciones privadas. A ellas se unirá Romero Brest en su política de sumar esfuerzos.” $\left(\right.$ GIUNTA, 2008, p. 76) ${ }^{36}$.

Essa nova rede abarcava locais oficiais e privados, prêmios orientados a promover a experimentação das vanguardas, surgimento de novas galerias, estímulo aos veículos de crítica e discussões sobre arte etc. Esse recente sistema mantinha relativa autonomia em relação ao circuito tradicional, oferecia visibilidade às propostas alternativas ao panorama plástico local e, inclusive, preparava condições para a promoção de artistas no exterior (LONGONI, MESTMAN, 2008, p. 42).

Nesse período, a instituição argentina que protagonizou o circuito modernizador foi a Fundação Torcuato Di Tella. No entanto, sabe-se por meio de alguns comentadores (KING, 2007), que houve uma intensa atividade no terreno artístico ao final da década de 1950, e vários grupos estavam experimentando em campos diferentes. Eles tiveram apoio de algumas galerias (entre as principais, Galeria Bonino e Lirolay) e outras instituições que auxiliavam essas iniciativas, como o MNBA e MAM. Nesse sentido:

El Di Tella no creó nada, sino que reunió y respaldó estas diversas iniciativas. Los comienzos de la década del 60 crearon un clima favorable para semejante proyecto y el Instituto pudo brindar instalaciones, fondos, respaldo crítico y uma estratégia internacionalista coerente. La combinación resultó ser assombrosamente importante y polémica. $(\text { KING, } 2007 \text {, p. } 55)^{37}$

\footnotetext{
36 "Os organismos capazes de levar adiante a transformação que o campo artístico necessitava não seriam aquelas dependentes do Estado, mas das novas fundações e instituições privadas. A elas se reunirá Romero Brest em sua política de somar esforços." (tradução nossa). Diante da carência de fundos para gerir o MNBA, Brest renuncia à gestão do Museu, em 1963, e oferece seus serviços ao ITDT, onde tomará a frente do Centro de Artes Visuais até o fechamento do Instituto em 1970, como veremos adiante.

${ }^{37}$ “O Di Tella não criou nada, apenas reuniu e respaldou essas diversas iniciativas. No começo da década de 60 criaram um clima favorável para semelhante projeto e o Instituto pôde brindar instalações, fundos, respaldo crítico e uma estratégia internacionalista coerente. A combinação resultou ser assombrosamente importante e polêmica." (tradução nossa).
} 


\subsection{3 - INSTITUTO Di TELLA}

A Fundação e o Instituto, que levam o nome Torcuato Di Tella ${ }^{38}$, foram criados em 1958. Sem fins lucrativos, buscaram se ancorar no objetivo de

Colaborar, por médios financeiros e intelectuales, al desarrollo material y espiritual de la Argentina [...] la colaboración de un grupo de especialistas internacionales [...] las bases para capacitar la institución como instrumento poderoso y dinámico de influencia en la evolución argentina. (GIUNTA, 2008, p. 326) ${ }^{39}$.

O Di Tella encarnou uma nova modalidade de mecenato cultural privado de perfil filantrópico, ligado aos setores da burguesia industrial, e disposto a apoiar o surgimento de novas vanguardas. Além de representar o dinamismo institucional aberto pelos programas modernizadores, procurou, também, articular a imagem cultural de um país que apostava no futuro e que pretendia articular-se aos grandes centros internacionais (GIUNTA, 2008, p. 32).

A primeira estratégia do empresário Guido Di Tella foi dar sequência à formação e atualização da coleção de seu pai, que continuou com a assessoria do crítico italiano Lionello Venturi. A coleção abrangia obras medievais, mestres da Renascença e numa trajetória linear, seguia os movimentos artísticos europeus até chegar aos impressionistas. Os mecanismos estéticos que ampararam a constituição desse colecionismo privado são visivelmente pautados em um paradigma modernista, cujo dispositivo se ajustou em uma concepção cronológica e evolutiva da história da arte. Como atesta Romero Brest, “[...] la Colección tuviera unidad en el desarrollo progresivo de las formas a partir del Medievo occidental". Ou ainda, quando volta ao mito inaugural da arte moderna, atesta que para haver um “[...] Al desarrollo

\footnotetext{
${ }^{38} \mathrm{O}$ Instituto Torcuato Di Tella foi inaugurado com o intuito de perpetuar a memória e os feitos do empresário industrial Don Torcuato Di Tella, falecido 10 anos antes. A direção ficou por conta de seu filho, Guido Di Tella, que deu continuidade aos empreendimentos familiares. Em nota de rodapé do livro Vanguardia, Internacionalismo y Política, Giunta (2008, p.326) escreve que o italiano Don Torcuato se estabelece na Argentina em 1905, e ali desenvolve ao longo de 40 anos uma enorme sociedade industrial que chegou a fabricar $80 \%$ das geladeiras domésticas vendidas no país, tornando-se um dos ramos do desenvolvimento industrial mais fortes do país. Em 1951, fundou o SIAM (Sociedade Industrial Americana de Maquinarias Di Tella), cuja porcentagem das ações (aproximadamente 10\%) era destinada ao Instituto Torcuato Di Tella.

${ }^{39}$ Trecho de texto do catálogo Colección Torcuato Di Tella, Premio Pintores Argentinos, Muestra Individual de Alberto Burri, Buenos Aires, MNBA, 1960. Colaborar por meios financeiros e intelectuais, ao desenvolvimento material e espiritual da Argentina" com "a colaboração de um grupo de especialistas internacionais" capazes de estabelecer "as bases para capacitar a instituição como instrumento poderoso e dinâmico de influência da evolução da Argentina" (Tradução nossa).
} 
posterior de la pintura es preciso llegar a la obra maestra de Édouard Manet” (BREST, 1992, p. $32-34){ }^{40}$

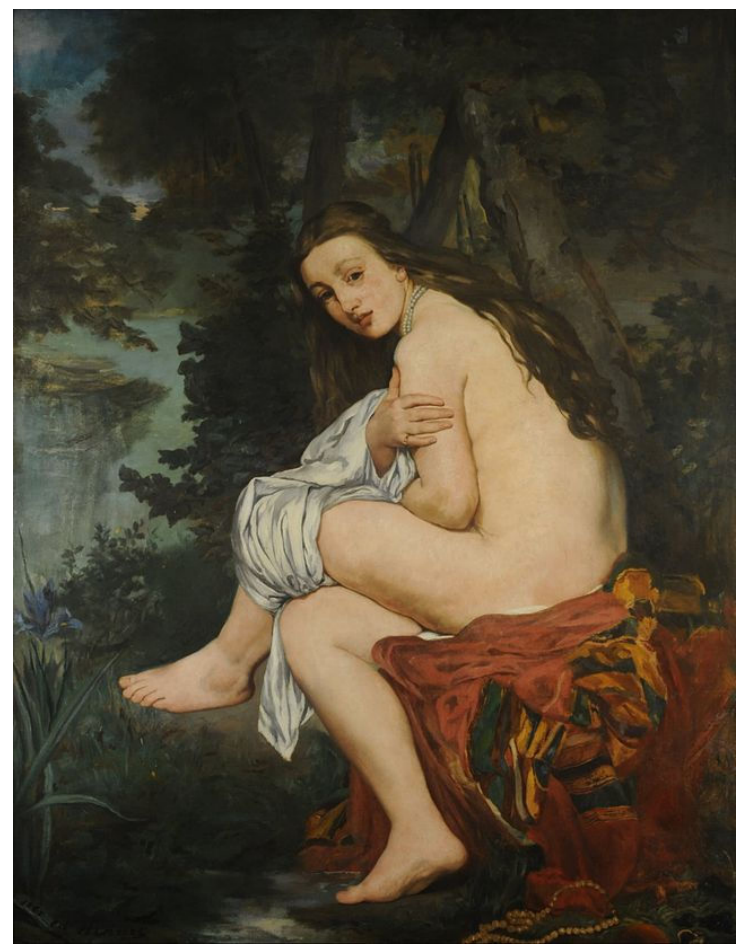

Figura 10 - Édouard Manet, La Ninfa Sorprendida, 1861

Óleo sobre tela, $144,5 \times 112,5 \mathrm{~cm}$.

Museu Nacional de Bellas Artes, Buenos Aires

O Instituto Torcuato Di Tella (ITDT) criou um Centro de Arte ${ }^{41}$ que durante seus primeiros anos funcionou nos espaços físicos do MNBA, seguindo um programa inicial elaborado por Guido Di Tella. Ele se baseava na montagem de uma galeria moderna para exibir a coleção Di Tella e na organização de mostras itinerantes (KING, 2007, p. 69). Esse primeiro Centro foi substituído pelo Centro de Artes Visuais (CAV), com sede própria, e gradualmente o objetivo inicial de Guido ganhou outras proporções criando um grande impacto no desenvolvimento cultural de Buenos Aires ao longo da década de 1960.

\footnotetext{
40 “[...] a Coleção teve unidade no desenvolvimento progressivo das formas a partir do Medievo ocidental.” [...] "Ao desenvolvimento posterior da pintura é preciso chegar à obra mestra de Édouard Manet." (tradução nossa).

${ }^{41}$ O Centro de Arte possuía um conselho sob a direção artística de Lionello Venturi, o professor de egiptologia Ricardo Camino, Guido Di Tella e Jorge Romero Brest (BREST, 1992, p. 22). Posteriormente contou somente com a supervisão de Romero Brest. No mesmo período, o ITDT criou outras áreas de investigação, como o Centro de Experimentação Audiovisual e o Centro Latino-americano de Altos Estudos Musicais.
} 
A missão adotada por Brest no CAV tinha o propósito de “a) cooperar en la difusión y la promoción de las artes visuales, b) mantener contactos con centros similares y personas vinculadas a las artes visuales, en el país y en el extranjero" (BREST, 1992, p. 22) ${ }^{42}$.

É fundamental relacionar as atividades do CAV ao crítico mais influente da época, Jorge Romero Brest. Desde a década de 1930, Brest conduzira com fôlego a crítica argentina e latino-americana. Publicou uma série de livros, atuou como professor, além de contribuir com a tradução para o espanhol de textos e livros de história da arte, que até então, pouco haviam circulado no ambiente intelectual argentino. Atualizou a área da crítica, sobretudo, na gestão da revista Ver y Estimar, na qual teorizou e defendeu a arte abstrata e a autonomia da arte pautada nos preceitos do modernismo. Nos anos de 1960, o crítico mudou os rumos teóricos, com a perspectiva de compreender e apoiar a nova produção dos jovens artistas locais. Como diretor do CAV, Brest agenciou as novas vanguardas, sobretudo no exterior, e transformou a estrutura das exposições e premiações, "para adaptarlos a los desafíos que planteaba el arte nuevo"43 (KATZENSTEIN, 2007, p. 10).

O ITDT inaugurou sua nova sede na rua Florida, local central e de grande visibilidade dentro da rede modernizadora portenha. Essa localização privilegiada concentrava em poucos quarteirões diversas galerias, cineclubes, áreas de boemia, livrarias, cafés e o recém-aberto departamento de sociologia da UBA (Universidade de Buenos Aires). Essa zona fícou conhecida como "la manzana loca", e ali circulavam diversas pessoas dispostas a consumir as novidades promovidas pelo Di Tella.

A ideia do CAV era atrair um público numeroso e o "Di Tella", como ficou conhecido esse espaço, buscou diversas estratégias para atingir esse objetivo. De acordo com John King (2007, p. 80-81), a fachada do edifício era convidativa, com uma entrada de vidro transparente e um grande lobby que facilitava o ingresso dos transeuntes. Oferecia boas condições para montagens de diferentes tipos de exposição, as instalações e o mobiliário eram limpos e modernos, era permitido fumar e tirar fotos; criando um ambiente mais informal e atrativo que outros espaços artísticos mais tradicionais. Somava-se a esse objetivo, promover a arte local e ampliar o público de arte de Buenos Aires, por meio de uma programação contínua de mostras e um horário de funcionamento mais amplo e mais flexível.

\footnotetext{
42 “a) cooperar com a difusão e a promoção das artes visuais, b) manter contatos com centros similares e pessoas vinculadas às artes visuais, no país e no estrangeiro." (tradução nossa).

43 "para adaptá-los aos desafios que estabelecia com a arte nova." (tradução nossa).
} 


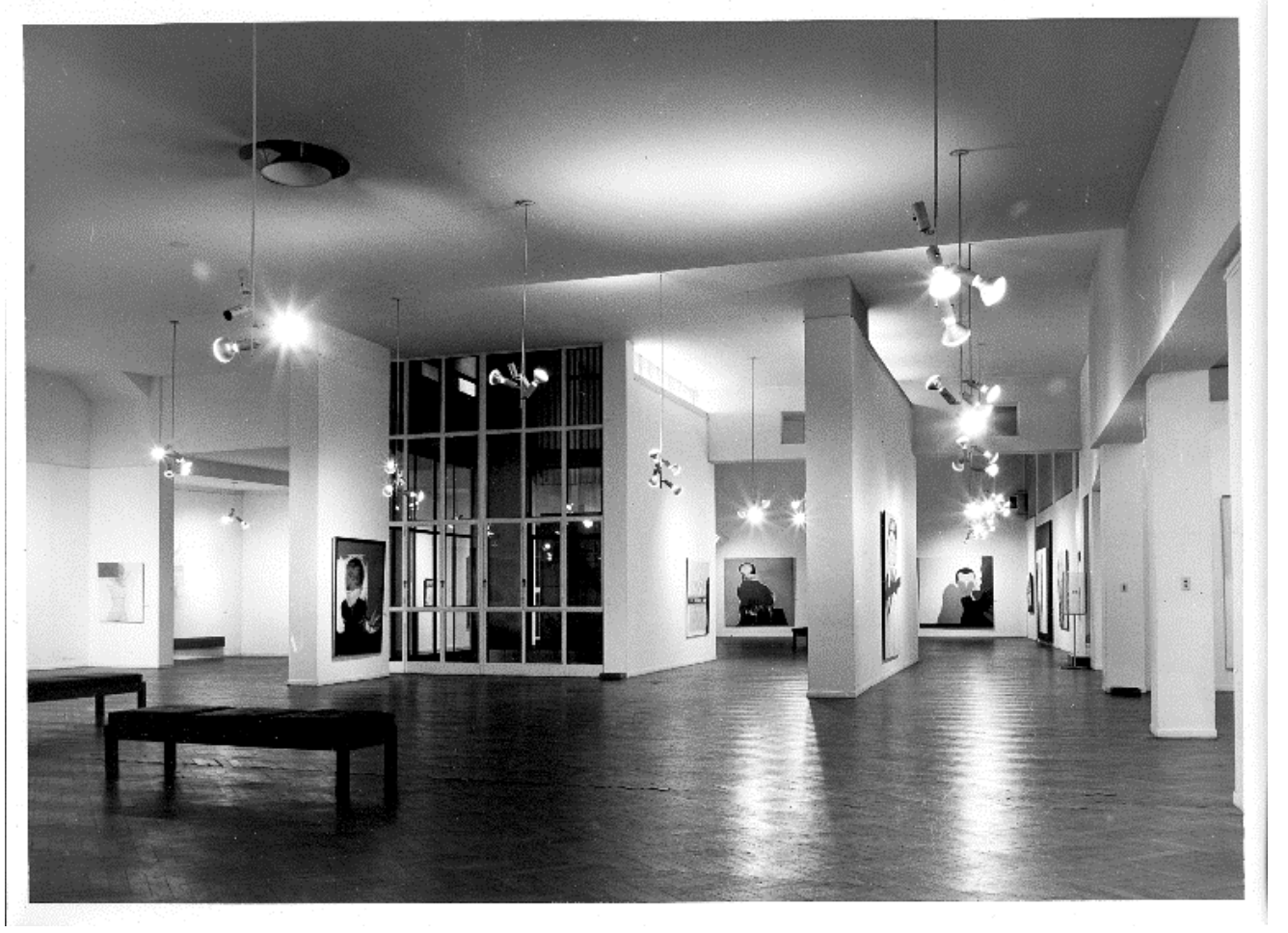

FIGURA 11 - Vista do CAV - Instituto Di Tella, 1967

Exposição de Rômulo Macció. Arquivo Instituto Torcuato Di Tella

As táticas institucionais para alavancar a nova sede do CAV aliavam-se a "[...] la busca de una cultura viva y actual que reemplazara la dominante, retórica, envejecida, incapaz de desarrollarse con autenticidad" (BREST, 1992, p. 24) ${ }^{44}$. O discurso de Brest é central para compreender a adesão total às novas vanguardas artísticas, que armavam sua linha de frente baseada em um espírito jovem renovador, distante da cultura de repetição "envelhecida". Em uma de suas diversas conferências, Brest assinalou:

Que no admitiríamos la repetición, por considerar inoperante la actitude creadora de quienes vuelven sobre lo hecho. [...] Con lo cual quise subrayar que nuestra vara no era la del valor, cuya estimación es social y por ello exige cierto grado de reconocimiento público, sino de la invención, aun mejor dicho, de la aventura... proponiendo um camino áspero pero auténtico hacia uma mayor liberdad de expressión [...]. (BREST, 1992, p. 24) ${ }^{45}$

A medida inicial de promoção e consagração das novas vanguardas se deu por meio de prêmios. Em 1960, o ITDT organizou o primeiro Prêmio Instituto Torcuato Di Tella, reunindo

\footnotetext{
44 "[...] a busca de uma cultura viva e atual que substituiria a dominante, retórica e envelhecida, incapaz de desenvolver-se com autenticidade." (tradução nossa).

45 "Que não admitiríamos a repetição, por considerar inoperante a atitude criadora dos que voltam sobre um fato. [...] Com o qual quis ressaltar que a nossa lança não fosse a do valor, cuja estimativa é social e por isso exige certo grau de reconhecimento público, mas o da invenção, melhor dizendo, da aventura... propondo um caminho áspero mas autêntico para uma maior liberdade de expressão [...].” (tradução nossa).
} 
obras de 25 pintores argentinos. No ano seguinte, incluiu o convite a artistas chilenos e uruguaios, sendo os da neofiguração argentina os principais premiados. Vale pontuar a destacada presença de Giulio Carlo Argan entre os jurados do Prêmio de 1961, inaugurando a vinda de importantes críticos e intelectuais internacionais aos júris dos Prêmios, que se prolongaram até 1967.

Os prêmios consistiam em bolsas de estudo no exterior (Europa e especialmente EUA), visando o contato do artista local com produções estrangeiras, além de impulsionar o vínculo com galerias comerciais e críticos de arte. A contrapartida da premiação era o regresso do artista ao país de origem a fim de estimular a produção local com o aprendizado obtido fora. Outra política de promoção eleita pelo Instituto foi a organização de mostras itinerantes da Coleção Di Tella no interior do país e em Montevidéu, no Uruguai.

Brest, em seu livro de memória sobre o Di Tella (1992, p. 41), conta que a ação do CAV começou a estender-se a outras províncias para além de Buenos Aires, com mostras como Daumier a nuestros días, no Museu Emilio Garaffa de Córdoba. Nota-se nesse programa um impulso inicial dos projetos de internacionalização, ainda restritos ao contexto latino-americano, mesmo sabendo que a ação do Di Tella nos países vizinhos foi bastante reduzida. $\mathrm{O}$ raio de interesse de intercâmbio institucional e de promoção da arte local se centralizaria na Europa e nos EUA, nos anos seguintes.

Em 1962 o Prêmio ${ }^{46}$ ampliou-se nas categorias nacional e internacional, e foi dedicado à escultura. A inserção de artistas internacionais buscava intensificar a comunicação e confrontação das produções mais recentes do exterior com a arte local, induzindo uma estratégica aproximação de campos artísticos ainda muito distantes. A missão maior encarada pelo CAV, e encabeçada por Romero Brest, foi "Promover, además a Buenos Aires como centro cultural a nivel internacional y atraer atenciones hacia la actividad plástica argentina" (BREST, 1992, p. 42). ${ }^{47}$

É válido ressaltar que essa ambição internacionalista ganhou novos contornos a partir da construção desse amplo programa que incluía a vinda de artistas e jurados estrangeiros; na busca de promover um contato imediato com a produção local e alavancar a arte argentina no rol dos debates mais atuais da época. O trecho de uma entrevista que Argan deu a um jornal

\footnotetext{
${ }^{46}$ Romero Brest, Giulio Carlo Argan e Johnson Sweeney (diretor do Museu Salolon R. Guggenheim de Nova Iorque) fizeram parte do júri e premiaram o artista argentino de matriz concretista Gyula Kosice com uma bolsa para estudar no exterior, e a norte-americana Louise Nevelson, com 3 mil dólares.

47 "Promover Buenos Aires como centro cultural a nível internacional e atrair atenções para a atividade plástica argentina." (tradução nossa).
} 
da época evidencia a expectativa argentina de atualização e inserção no panorama internacional, que contou com o auspício de críticos de renome mundial: "O Prêmio Di Tella deste ano alcançou um nível de qualidade que o põe em pé de igualdade com manifestações desse caráter em plano internacional" (Argan apud BREST, 1992, p. 44).

Acreditava-se que as distâncias entre a Argentina e as grandes capitais da Europa e dos EUA, em especial Nova Iorque, tornavam-se cada vez mais estreitas; e começava a se sedimentar no imaginário da época a inserção de Buenos Aires na rota dos grandes centros culturais e como ponto de radiação artística. Pierre Restany, um dos jurados do Prêmio Di Tella de 1964, ficou eufórico ao visitar a capital da Argentina: "Buenos Aires me fascinó. Es una de las verdaderas metrópolis [...] Está en las vísperas de una gran mutación orgánica comparable a aquella que ha hecho de Nueva York un centro internacional de la creación contemporánea" (RESTANY apud SHAW, 1998, p. 78) ${ }^{48}$.

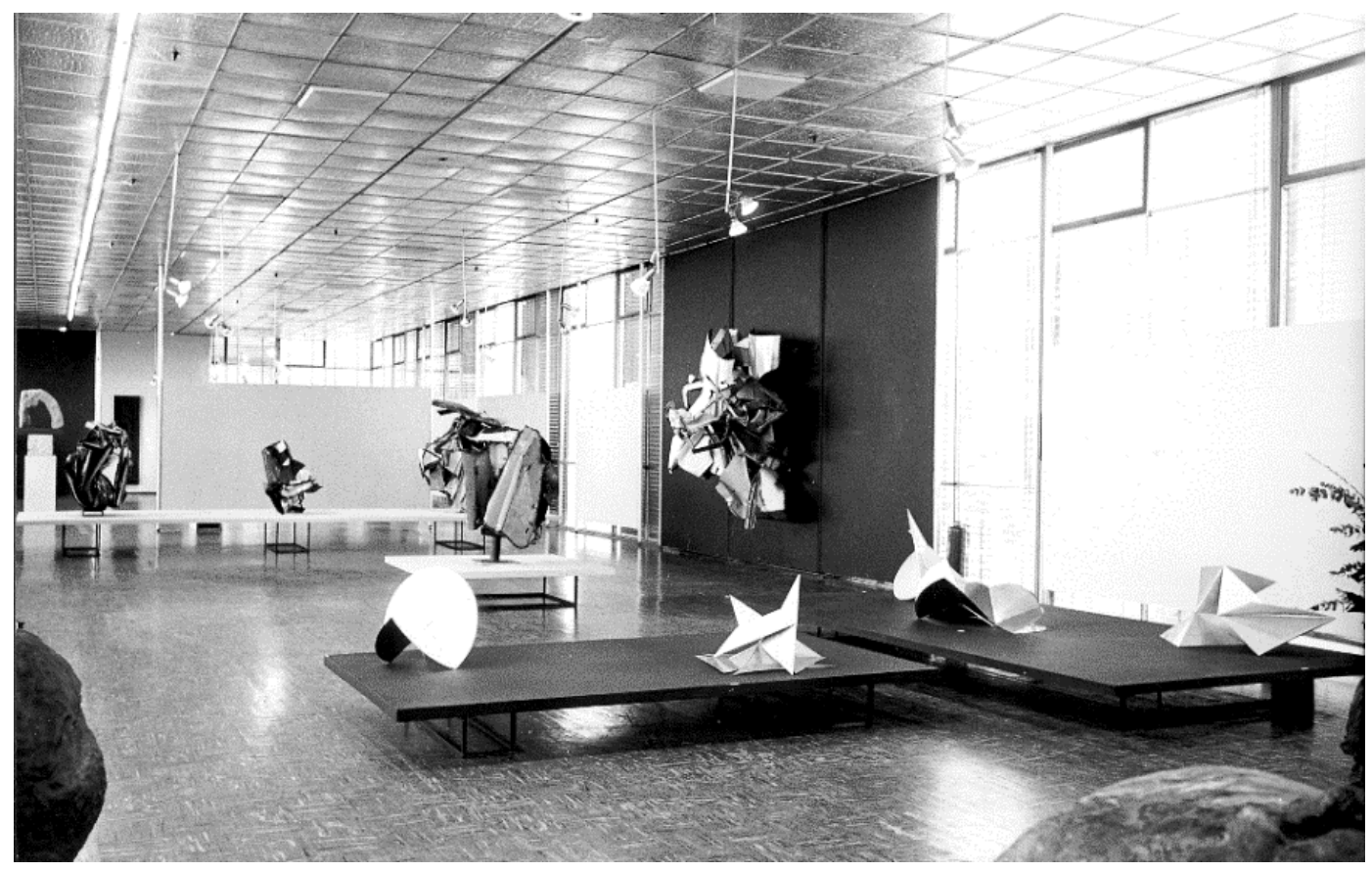

FIGURA 12 - Vista do Prêmio Nacional e Internacional ITDT, 1962

(Detalhe da obra Bichos, de Lygia Clark)

Arquivo Instituto Torcuato Di Tella

48 "Buenos Aires me fascinou. É uma verdadeira metrópole [...] Está às vésperas de uma grande mutação orgânica comparável àquela que fez de Nova Iorque um centro internacional de criação contemporânea." (Tradução nossa). 
Para melhor compreender as políticas de internacionalização é fundamental analisar quais foram os processos de seleção e legitimação de artistas e dos novos movimentos artísticos desse recente circuito. Ou seja, quais foram esses artistas e por meio de quais linguagens era possível alcançar a internacionalização da arte argentina. Além disso, quais foram os critérios de consagração dessa nova vanguarda e as estratégias de exportação selecionadas pelas instituições protagonistas desse período. Acredito que sejam pontos basais que permitem ampliar os relatos para além da descrição das características formais dos objetos, ao inscrevê-los em um diálogo multifocal onde a configuração das instituições e a relação estabelecida com as vanguardas artísticas são algumas das questões que formulam o tema analisado.

A ofensiva modernizadora da década de 1960 pode ser lida na chave da internacionalização como uma das prioridades basais dos programas institucionais do período. Os empenhos para inserir a arte argentina, sobretudo a nova arte, nos circuitos internacionais, foram constantes. Ao longo dessa década, diversas exposições de artistas locais foram promovidas na Europa e nos EUA. As delegações argentinas nas Bienais de São Paulo, Veneza e Paris constituíram parte de uma ação constante, articulada pelo Estado e promovida com subsídios de empresas privadas (PACHECO, 2007, p. 16)

Sabemos que as condições políticas e econômicas favorecidas por consórcios como a Aliança para o Progresso; ou ainda, o Centro de Relações Interamericanas, com financiamento da Fundação Rockefeller, formou o horizonte dos intercâmbios culturais na América Latina durante a década de 1960. Pode-se inscrever nessa órbita mais ampla de trocas a exposição New Art of Argentina ${ }^{49}$, organizada pelo CAV em conjunto com o Walker Art Center de Minneapolis, em 1964. Composta por obras de mais de trinta artistas argentinos, a mostra circulou pelos EUA e representou as tendências mais modernas do país. No catálogo, Romero Brest ressaltou o otimismo e o progresso da arte argentina, promovidos por artistas das novas gerações que ousaram romper com os "moldes" por meio "de atitudes mais livres".

[...] Por otra parte el valor de las obras no es producto de una mera comparación de formas y realidades, [...] sino de la incitación a la liberdad que sean capaces de provocar. De modo que siendo las obras de "valor

\footnotetext{
${ }^{49}$ Sabe-se, por meio da documentação do Arquivo ITDT, que a exposição New Art of Argentina fez parte da programação das comemorações do IV centenário da cidade do Rio de Janeiro. Em um formato menor, foi exposta no MAM RJ, de 7 de outubro a 7 de novembro de 1965. No Capítulo 2 desta dissertação, analisaremos com mais profundidade os intercâmbios institucionais entre Brasil e Argentina.
} 
nacional' más limitadas, no hay más remedio que seleccionar las más amplias de 'valor internacional' (BREST, 1992, p. 67). ${ }^{50}$

O "valor nacional" a que Brest se refere estava intimamente ligado às temáticas nacionais como a cultura dos pampas e as tradições gauchescas que representavam um regionalismo ultrapassado. Ousadia e liberdade estavam no front, encarnados pelo "valor internacional". Nesse momento, já não havia mais a antiga querela entre abstratos e figurativos que marcara os principais debates da década anterior. Se voltarmos para a sequência de ismos da história da arte oficial notaremos que no decorrer da década de 1960 a abstração pictórica ${ }^{51}$ havia perdido fôlego e as novas tendências artísticas pareciam se distanciar cada vez mais dos pressupostos greenberguianos de visibilidade pura e autodefinição.

O enfraquecimento da recepção da crítica de base formalista greenberguiana coincidiu com a ascensão da pop art e o início de um período marcado pela falta de unidade estilística e pela sucessão acelerada de movimentos como hard-edged, minimalismo, op art, arte cinética, arte povera, novo realismo francês, arte conceitual etc. Ao lidar com imagens da cultura de massa a pop acabou por violar os princípios puristas do arsenal formalista do crítico, evidenciando sinais de esgotamento da tradição modernista. Arthur Danto (2006) definiu como o fim da arte esse momento de colapso da pintura moderna e da autonomia absoluta, ou seja, o término de certa narrativa da história da arte.

É, de determinada perspectiva, um período de desordem informativa, uma condição de perfeita entropia estética. Mas é também um período de impecável liberdade estética. Hoje não há mais qualquer limite histórico. Tudo é permitido. [...] Refiro-me ao final de certa narrativa que foi desvelada na história da arte no decorrer dos séculos, e que chegou ao seu fim em meio a certa liberdade de conflitos que eram inescapáveis na Era dos Manifestos (DANTO, 2006, p. 15-42).

$\mathrm{Na}$ Argentina, o apoio ao pluralismo das novas linguagens, bancado pelo Di Tella, ofereceu aos artistas um terreno fértil de experimentação artística. A revisão dos modos de figuração, principal agenda dos artistas da nova figuração no início dos anos de 1960, e o distanciamento das concepções tradicionais de pintura de cavalete e escultura, no decorrer da

\footnotetext{
50 " [...] Por outra parte, o valor das obras não é produto de uma mera comparação de formas e realidades, [...], mas a incitação à liberdade que seja capaz de provocar. De modo que sendo as obras de 'valor nacional' mais limitadas, não há mais remédio que selecionar as mais amplas de 'valor internacional' (tradução nossa).

${ }^{51}$ Expressão utilizada por Clement Greenberg para referir-se ao movimento que ficou conhecido como Expressionismo abstrato, que o crítico se referia com aspas ou ressalvas.
} 
década, se uniam à imprescindível ativação do espectador no centro das novas experiências. A incorporação de materiais não artísticos, extraídos da vida cotidiana, e o sentido de transitoriedade das obras, marcada por obras e exposições efêmeras, também direcionavam um caminho de novos paradigmas aos artistas.

Podemos identificar um importante antecedente desse novo campo artístico na mostra coletiva Arte Destructivo ${ }^{52}$, realizada na Galeria Lirolay, em 1961. A proposta partia de uma experiência multissensorial envolvendo imagens e sons que aludiam a temáticas ligadas ao sexo, à morte e à violência. Os artistas dispuseram objetos cotidianos que haviam sido alterados, queimados ou destruídos, apontando diferentes possibilidades de destruição, que podiam ser lidas numa chave estética cujas referências iam do Dadaísmo e do Surrealismo a uma gestualidade violenta do informalismo pictórico.

Se me ocurrió que sería interessante canalizar esta tendencia destructiva del hombre, esta agresividad reprimida en la mayoría de los casos pero siempre pronta a explotar nocivamente, en una experiencia artística totalmente inofensiva. Se me ocurrió pensar en lo que pasaría si un grupo de artistas se dedicasse a destruir, a romper objetos u obras de arte, en vez de realizar su labor habitual. Es decir, prácticamente intentar el processo inverso de la creación. ${ }^{53}$ (KEMBLE apud KATZENSTEIN, 2007, p. 31).

\footnotetext{
${ }^{52} \mathrm{O}$ artista Kenneth Kemble foi o mentor do projeto Arte Destructivo e convidou os artistas Luis Alberto Wells, Enrique Barilari, Jorge López Anaya, Jorge Roiger, Antonio Seguí e Silvia Torras para a mostra.

53 “Ocorreu-me que seria interessante canalizar esta tendência destrutiva do homem, esta agressividade reprimida na maioria dos casos, mas sempre pronta para explorar nocivamente em uma experiência artística totalmente inofensiva. Ocorreu-me pensar o que aconteceria se um grupo de artistas se dedicasse a destruir, romper objetos ou obras de arte, em vez de realizar o seu trabalho habitual. Quer dizer, praticamente tentar o processo inverso da criação." (tradução nossa).
} 


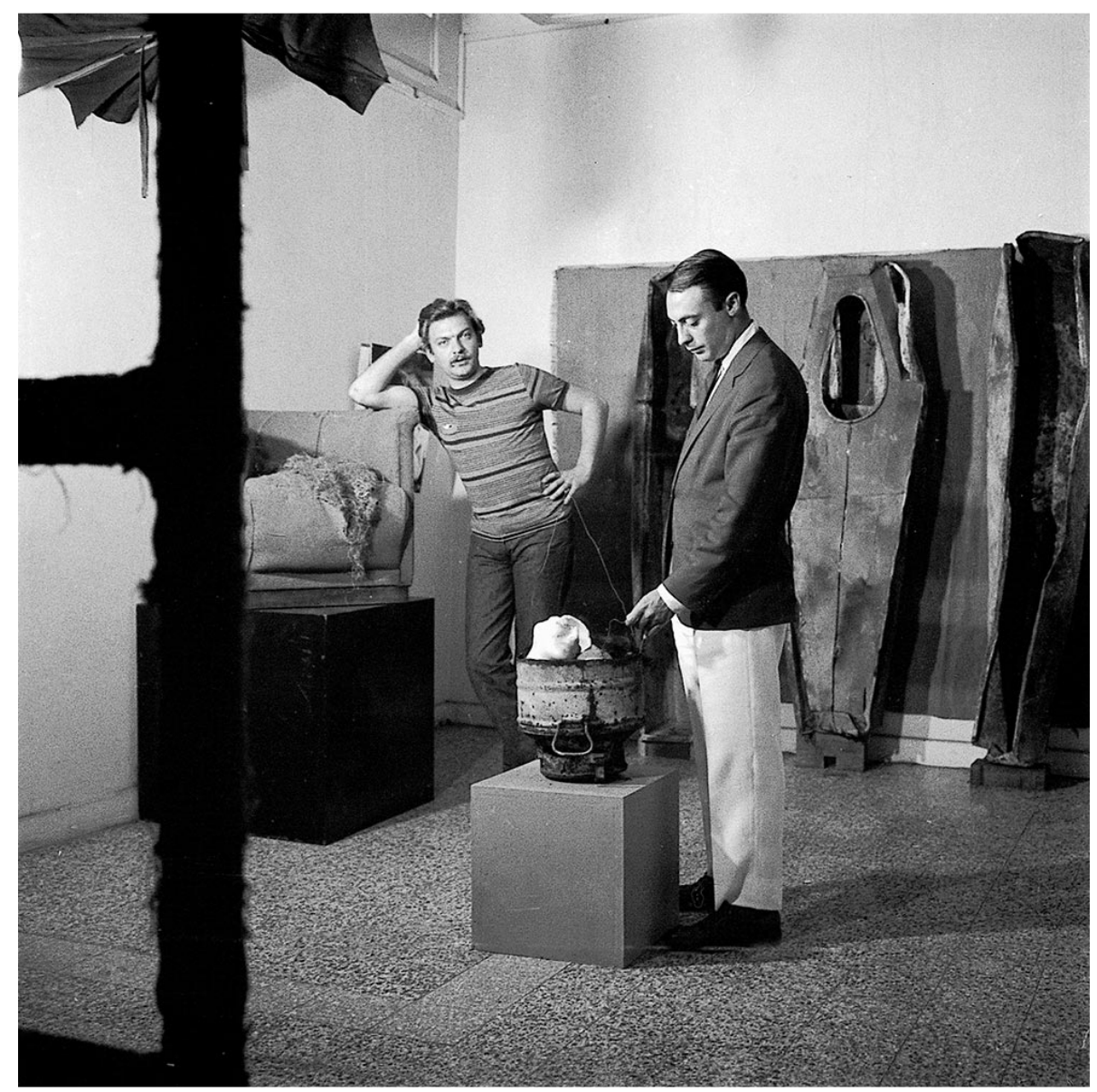

Figura 13: Vista da mostra Arte Destructivo. Galeria Lirolay (1961).

Outra referência que podemos articular a essas novas experiências estéticas foi a ação realizada por Marta Minujín, em 1963, no Impasse Ronsin, em Paris. Minujín, artista pioneira do happening e arte ambiental na América Latina, organizou em seu ateliê uma mostra com a artista portuguesa Lourdes Castro e com o venezuelano Alejandro Otero. Ao finalizar a exposição na qual expôs uma série de colchões e relevos de cartão, convidou outros $\operatorname{artistas}^{54}$ para participarem da ação que ficou conhecida como La destrucción. As obras foram levadas para um terreno baldio e os artistas poderiam intervir nos trabalhos de acordo com seus próprios métodos. O poeta surrealista Flammand interferiu nos colchões ao modo de um médico, dissecando as obras com instrumentos cirúrgicos. Christo cobriu Minujín e os colchões com um pano branco, de maneira similar às suas intervenções monumentais em que prédios e paisagens são literalmente empacotados. Ao término de todas as interferências artísticas, Minujín ateou fogo nas obras e soltou mais de quinhentos pássaros ao ar e cem

\footnotetext{
54 Os artistas que participaram foram: Erik Beynom, Christo, Élie-Charles Flammand, Paul Gette, Manolo Hernández, Jean-Jacques Lebel e Daniel Pommereulle (MINUJíN, Marta. Marta Minujín: obras 1959-1989. Buenos Aires|: Malba, 2010).
} 
coelhos. Esse ato culminou em uma ação de destruição total das obras, na qual podemos verificar um distanciamento da noção de eternidade da obra de arte tradicional; além de introduzir novos participantes no processo de criação (destruição) do trabalho.

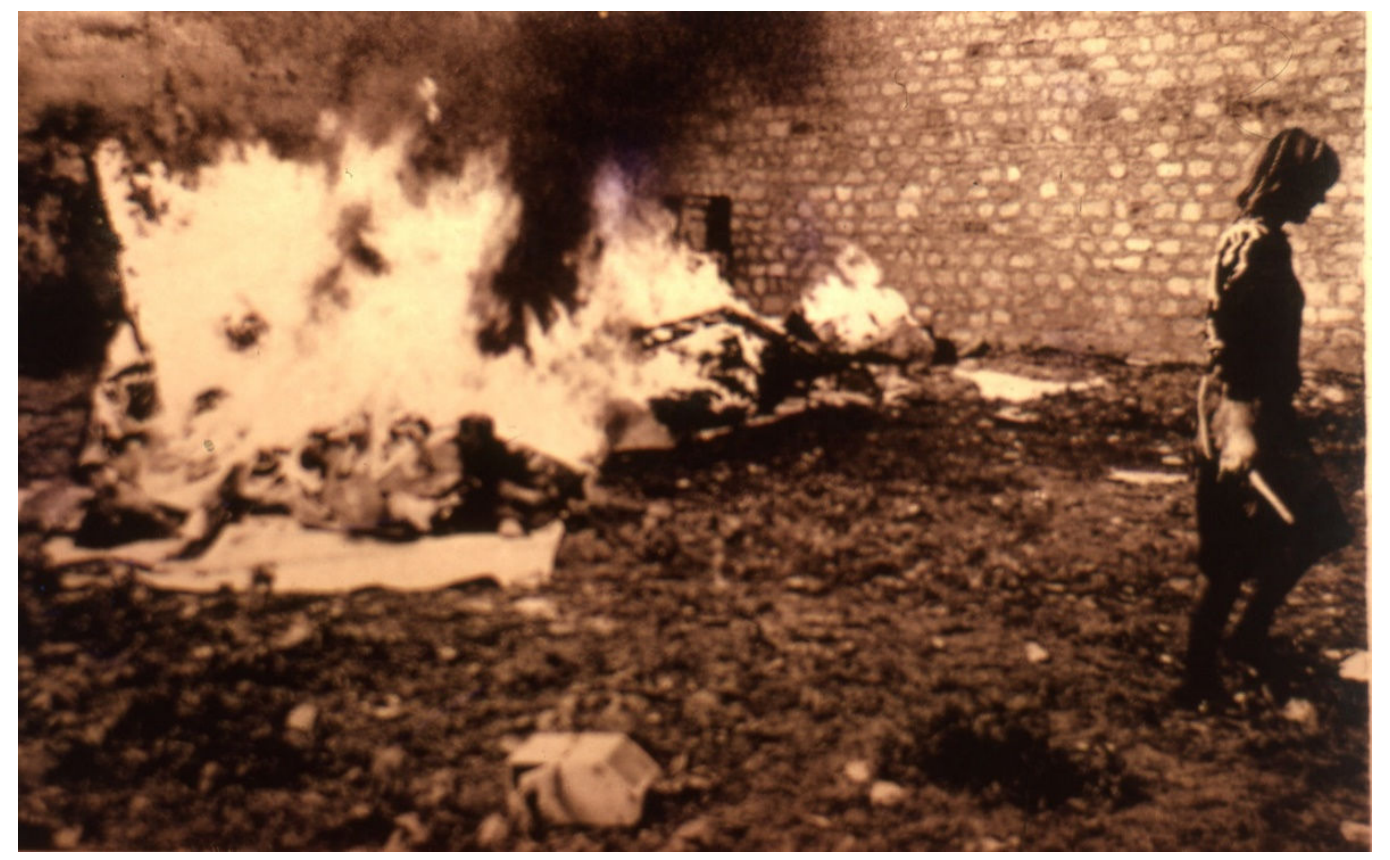

Figura 14 - La Destrucción, Marta Minujín Fotografia, 1963

O vetor comum entre a Arte Destructivo de Kemble e os colchões destruídos de Minujín transita entre o abandono dos formatos convencionais e a opção pela efemeridade da obra, da exposição, e do conceito de autoria individual. São propostas que conduziram a uma busca de múltiplas possibilidades de criação de objetos e ambientações, que iam muito além do valor da obra de arte autônoma. Foram ações que abriram espaço para a firmação de novos territórios que antes não eram considerados artísticos e que dificilmente contariam com o apoio institucional.

Essa nova geração descobria o momento como algo "virgem", uma tábula rasa na qual as possibilidades para as situações de comunicação, experiências grupais e caminhos criativos pareciam inesgotáveis (DOLINKO, 2010, p. 31). "A morte da pintura" adotada por diversos artistas apontava para algumas das rupturas dessa década, ou seja, não era mais plausível seguir produzindo tal como havia se entendido canonicamente, e dificilmente haveria algum termo de negociação com a tradição anterior. As artes visuais já não abrangiam somente aspectos da visualidade e ampliavam-se para propostas, ações e ideias como forma essencial 
de indagação experimental. Como podemos analisar, na reflexão de Aldo Pellegrini sobre as novas tendências da arte em seu país:

El tercer período, muy reciente, se caracteriza, desde un punto de vista exterior, por la ruptura de los limites entre figuración y abstración, y desde el punto de vista más profundo por una ruptura con la tradición del buen gusto y más que nada con um sentido de la libertad total para la creación que no se considera subordinada a ninguna norma ni principio a priori. ${ }^{55}$ (PELLEGRINI apud PACHECO, 2007, p. 26).

O ano de 1964 foi significativo para o circuito artístico portenho e é válido recordar que os ecos da Bienal de Veneza desse mesmo ano, em que o artista norte-americano Robert Rauschenberg fora o grande premiado, chegaram a Buenos Aires. Esse acontecimento simbolizava a conquista da arte pop e o deslocamento do eixo artístico de Paris para Nova Iorque. Podemos identificar que alguns sintomas desse novo panorama desembarcaram na capital portenha. Por exemplo, a vinda de Pierre Restany e Clement Greenberg, dois críticos de posturas totalmente antagônicas, que foram membros do júri do $4^{\circ}$ Prêmio Nacional e Internacional ITDT. Restany, principal orquestrador do Novo Realismo; Greenberg, figura que contribuiu para o êxito internacional do expressionismo abstrato, reproduziam no Di Tella a conhecida inimizade entre franceses e norte-americanos. O conflito, contudo, era mais de modelos estéticos do que de nacionalidades (GIUNTA, 2008, p. 214).

A disputa entre os modelos opostos evidenciou-se na seleção dos premiados. Greenberg ganhou a seleção da categoria internacional e destinou a recompensa ao pintor Kenneth Noland. O prêmio nacional ficou entre Emilio Renart, com o voto de Greenberg, e Marta Minujín, que contou com o apoio de Restany. Romero Brest desempatou, destinando a primeira colocação à Minujín, que havia apresentado Eróticos en color e Revuélquese y viva!. Sobre essa decisão, Romero escreveu:

Debí meditar más de veiticuatro horas para emitir finalmente mi voto por Marta Minujín, pues pensé que estaba abriendo uma posibilidad de creación absolutamente nueva, como se confirmó despues. La obra de Marta era una incitación a la vida em el plano contingente. [...] gracias a los valores plásticos de sus colchones y almohadones, menospreciados por los reaccionarios [...]. ${ }^{56}$ (BREST, 1992, p. 54)

\footnotetext{
55 "O terceiro período, muito recente, se caracteriza, de um ponto de vista exterior, pela ruptura dos limites entre figuração e abstração, e do ponto de vista mais profundo por uma ruptura com a tradição do bom gosto, e mais que nada com um sentido de liberdade total para a criação que não se considera subordinada a nenhuma norma nem princípio a priori." (tradução nossa).

56 "Meditei mais de 24 horas para finalmente emitir o meu voto pela Marta Minujín, pois pensei que estava abrindo uma possibilidade de criação absolutamente nova, como se confirmou depois. A obra de Marta era um
} 
Algumas notas de jornal da época que noticiaram amplamente a presença dos críticos, da exposição e o resultado da premiação polêmica, tentaram situar a linha de pensamento dos júris. A matéria Consideraciones sobre el premio Di Tella buscava posicionar o leitor dentro das discussões geradas pela exposição e, principalmente, com relação à postura encarada pelo ITDT em atualizar e acompanhar as preocupações "de las vanguardias del mundo entero". ${ }^{57} \mathrm{O}$ público seguia os debates por meio das declarações dos jurados, assim como a seleção das obras premiadas que consolidava esses discursos. Na mesma matéria, Restany dava luz à sua agenda estética, marcada pela necessidade de responder as reverberações da sociedade de consumo e as implicações nas manifestações artísticas desse novo modelo cultural:

El artista, frente a la competência desmoralizadora ejercida por los últimos descubrimientos científicos, "descubre" a la naturaleza de nuestra centuria, industrial, publicitaria, urbana, y la subjetiva por la "apropriación" pura y simple, la acumulación, la comprensión o la ruptura de los objetos que la componen. ${ }^{58}$

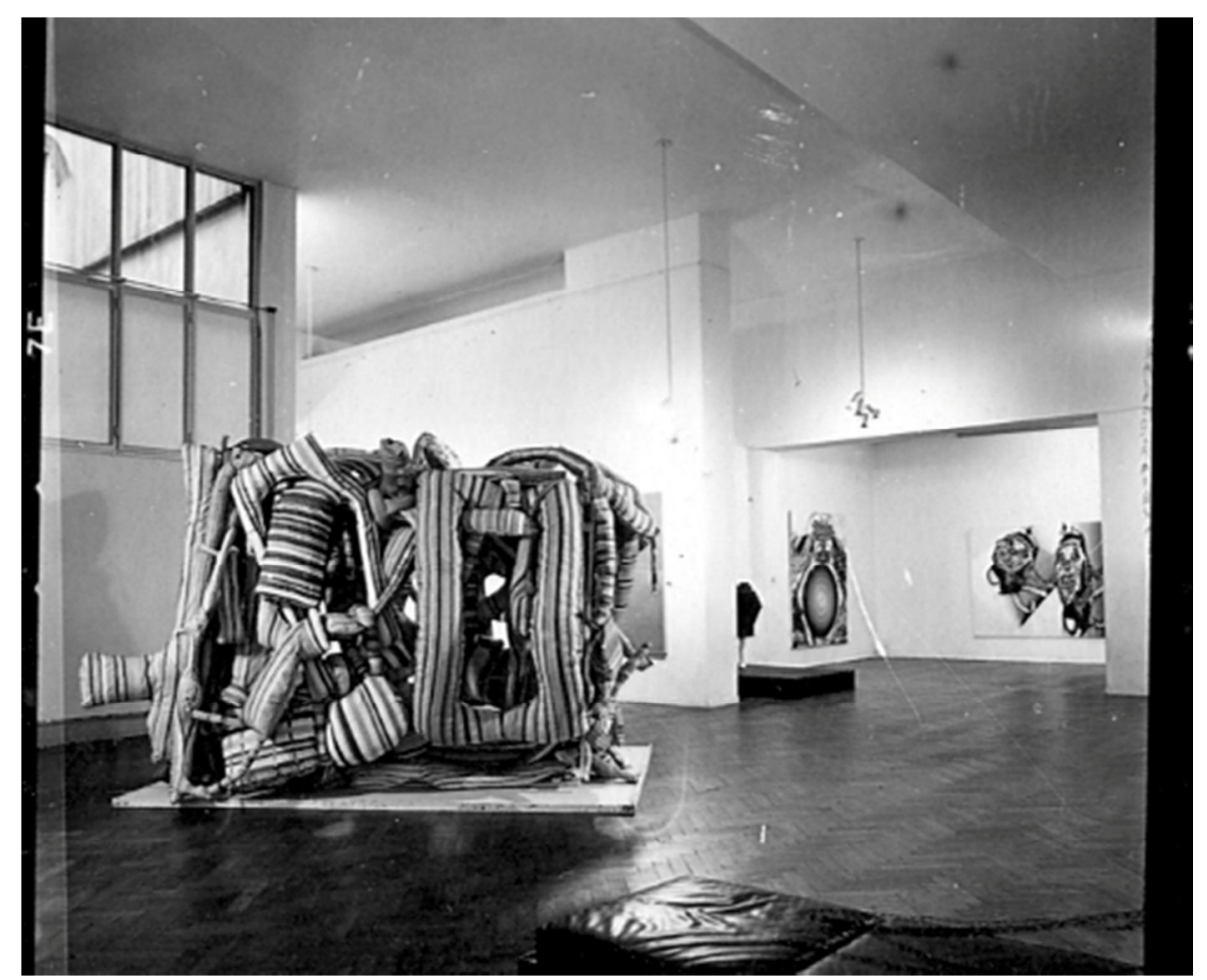

Figura 15 - Vista do Prêmio Nacional e Internacional ITDT, 1964

(Detalhe da obra Revuélquese y viva!, de Marta Minujín)

Arquivo Instituto Torcuato Di Tella

estímulo à vida no plano contingente. [...] graças aos valores plásticos de seus colchões e almofadas, menosprezados pelos reacionários [...]." (tradução nossa).

57 "das vanguardas de todo o mundo" (tradução nossa). La Nación, 10 out.1964. Arquivo Instituto Torcuato Di Tella)

58 “O artista, frente à competência desmobilizadora exercida pelas últimas descobertas científicas, "descobre" a natureza de nosso século, industrial, publicitária, urbana, e a subjetiva pela 'apropriação' pura e simples, a acumulação, a compreensão ou a ruptura dos objetos que a compõe.” (tradução nossa). La Nación, 10 out.1964. Arquivo Instituto Torcuato Di Tella. 
"Es neoyorquino, tiene 56 años, una gran simpatia, y aspecto de afable boxeador, más que de crítico de arte". ${ }^{59}$ Dessa forma o jornal descrevia Greenberg, com qualidades difíceis de imaginar para quem se acostumou ao tom severo e ortodoxo de seus textos. E no decorrer da matéria, o crítico ia se distanciando das características atribuídas pelo periódico, deixando clara as suas opiniões assertivas sobre a pop art: "é uma arte menor, uma moda, - usa a expressão "vogue" -, e é horrível dizer isto de qualquer expressão artística. O que prova a facilidade com que teve êxito, sem luta nem resistência". ${ }^{60}$

A preferência de Greenberg por Renart e Noland, estava em compasso com os pontos centrais de seu programa modernista, ajustado ao conceito de progresso e autonomia das formas. A linha evolutiva inaugurada por Manet encontrou seu auge na abstração pictórica norte-americana e, nesta ocasião, buscava seu último sopro nas margens dos grandes centros artísticos. No entanto, a protagonista da vez era Marta Minujín, que se transformara em um grande fenômeno massivo. O triunfo da arte pop também aterrissava em Buenos Aires. A obra premiada impactou Restany, que viu em Minujín o símbolo de uma geração em ascensão, consciente de seu destino e do objetivo de suas buscas.

\subsection{4 - POP, HAPPENING E ARTE DE LOS MEDIOS}

Era a primeira vez que se premiava uma linguagem nova e de caráter objetual. A apropriação de colchões retorcidos e pintados com cores fortes formavam uma pequena ambientação com música, cujo espaço interior o espectador podia entrar e se envolver em uma experiência lúdica e tátil com a superfície das grandes almofadas. No artigo Buenos Aires y el nuevo humanismo, de 1965, Restany escreveu sobre a obra da artista: "extraordinárias arquiteturas de almofadas feitas com tela de colchão [...] é uma visão livre, uma nova mirada sobre o mundo [...]" (RESTANY apud SHAW, 1998, p. 78). ${ }^{61}$ A ativação do campo vivencial do participante, mais habituado à contemplação, ampliava o seu papel na experimentação, tornando-a mais viva (como sugeria próprio título da obra). Sem dúvida, a premiação causou polêmica e escandalizou o público acostumado à arte como reflexo dos mais altos valores morais, religiosos e nacionais (HERRERA, 2010, p. 8) - uma arte que deveria estar localizada

\footnotetext{
59 "É novaiorquino, tem 56 anos, uma grande simpatia e aspecto afável de boxeador, mais que de crítico de arte." (tradução nossa). La Nación, 2 de outubro de 1964. Arquivo Instituto Torcuato Di Tella)

60 "Es un arte menor, una moda, - usa la expresión "vogue" -, y es algo horrible decir esto de cualquier expresión artística. Lo prueba la facilidade com que tuvo éxito, sin lucha ni resistencia. La Nación, 2 out. 1964. Arquivo Instituto Torcuato Di Tella.

61 "Extraordinarias arquitecturas de almohadas hechas con tela de colchón [...] es una visión liberada, una mirada nueva sobre el mundo." (tradução nossa).
} 
sobre um pedestal ou emoldurada em uma tela. Havia uma incompreensão da crítica jornalística e do público, que até então não tinham familiaridade com a produção vanguardista apoiada pelo Di Tella.

Enrique Oteiza, diretor executivo do ITDT, lançou uma nota à imprensa em que destacou o papel do CAV no estímulo ao desenvolvimento da produção plástica argentina e no interesse pela produção contemporânea. Também rebateu as críticas negativas que circularam nos jornais e revistas da época, que acusavam o Centro de favorecer os artistas jovens e apoiar somente novidades, tal como escreveu Córdova Iturburu na matéria Arte Apto y no apto para menores en Di Tella:

El Progreso [...] en ciertos medios atuales afronta el peligro de ser juzgado retrógrado. [...] Confieso, de manera pública, que la Novedad, por la gravitación de sus esencias, no me infiere sensaciones que me recorran la medula con estremecimientos inolvidables. ${ }^{62}$

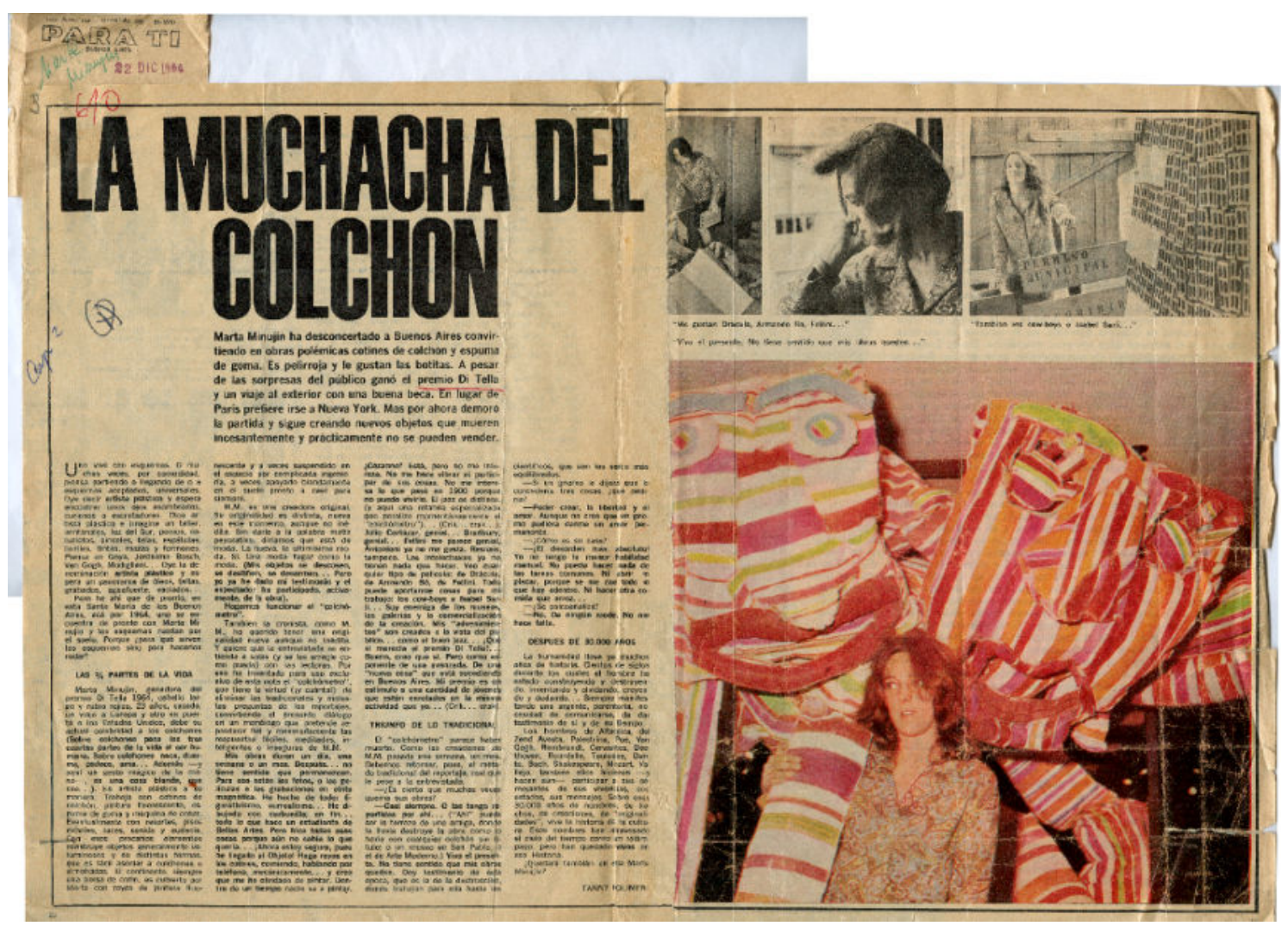

Figura 16 - La muchacha del colchon

Jornal Para ti, 22 dez. 1964. Arquivo Instituto Torcuato Di Tella

62 “O Progresso [...] em certos meios atuais afronta o perigo de ser julgado como retrógrado. [...] Confesso, de maneira pública, que a Novidade, pela gravitação de suas essências, não me induz sensações que percorram a medula com sobressaltos inesquecíveis.” (tradução nossa). El Mundo, 7 set. 1964. Arquivo Instituto Torcuato Di Tella. 
As novas linguagens artísticas eram encaradas sob a perspectiva de uma grande confusão sem regras e cânones e considerava-se que parte do que era exposto não deveria ganhar o estatuto de obra de arte. Não obstante, essa produção já não podia ser interpretada de acordo com os parâmetros utilizados para avaliar os movimentos artísticos anteriores. A necessidade de conduzir os recentes rumos e explicar as transformações na arte contemporânea tornou-se um ponto importante para inserir a nova plástica no âmbito local. Fazia parte da política de Romero Brest a realização de uma série de conferências $^{63}$ que acompanhava a maior parte das mostras abertas ao público no Di Tella. Foi uma forma de divulgar as exposições, criar um espaço didático para esclarecer as premissas das vanguardas e um palco fundamental para debater as polêmicas que envolviam artista, público e, sobretudo, o domínio da crítica jornalística, como vimos acima. Entretanto, o CAV não estava apenas interessado nas "novidades". Havia uma certa prudência de Brest em conservar o equilíbrio entre a agenda expositiva, intercalando as premiações mais controversas com a montagem de mostras que atraíam um tipo de público mais ortodoxo e que recebia aprovação da cobertura periodista (KING, 2007, 92).

O ambiente de confrontação ocasionado pelo contato de obras argentinas e estrangeiras, o intercâmbio e o embate de modelos estéticos regidos pelos jurados e a difusão das novas tendências conflagraram uma fecunda mudança no circuito artístico. Os critérios de legitimação que agenciaram a ascensão da arte jovem pautaram-se na institucionalização das práticas estéticas das novas vanguardas. Vale apontar que a modalidade de vanguarda amparada pelo Di Tella inclinava-se mais para as formulações provenientes da moda, do espírito de aventura, novidade e jovialidade, do que do sentido de transformação radical do homem e da sociedade através da arte, exercido pelas vanguardas históricas.

Neste momento, vale fazer uma breve pausa para situar o conceito de vanguarda na historiografia da arte, uma vez que esse termo fora utilizado amplamente por artistas e críticos argentinos para designar um grupo específico de artistas que buscaram renovar as linguagens artísticas ao longo dos anos de 1960. Vamos nos deter sobre duas posições distintas (em particular a de Peter Bürguer e Hal Foster) para aprofundar a relação entre as vanguardas históricas ou heroicas da primeira metade do século XX e as estratégias culturais e políticas das chamadas "neovanguardas" dos anos 60.

\footnotetext{
${ }^{63}$ No ano de 1964, por exemplo, o CAV organizou uma série de conferências. Entre elas: Orígenes del arte moderno en la Argentina; Problemas de método y el futurismo en la Argentina; Pintura tibetana, El arte colonial, Los premios Instituto Torcuato Di Tella etc. (BREST, 1992, p. 61)
} 
O desenvolvimento da sociedade burguesa e sua conquista de poder político, na segunda metade do século XIX, esteve atrelado à formação da autonomia da arte (arte pela arte), assim como a perda de seu caráter político. De acordo com Peter Bürguer (2008), a carência da função social, como essência do sistema burguês, foi superada na prática pelo movimento das vanguardas históricas.

A intenção dos vanguardistas pode ser definida como a tentativa de
direcionar a experiência estética (que se opõe à práxis vital), tal como o
esteticismo a desenvolveu, para a vida cotidiana. Aquilo que a ordem da
sociedade burguesa mais contesta, ordem esta orientada pela racionalidade-
voltada-para-os-fins, deve ser transformado em princípio de organização da
vida. (BÜRGUER, 2008, p.72).

Para o autor, somente as vanguardas europeias como os dadaístas e os surrealistas, por exemplo, conseguiram atacar o status da arte da sociedade burguesa, organizando, a partir da própria arte, uma nova práxis vital. Contudo, ainda com o apoio de Burgüer, não houve um projeto de continuidade da agenda das vanguardas pelas neovanguardas, exatamente porque houve um fracasso na intenção vanguardista de superação de arte (mesmo que a vanguarda tenha produzido um efeito revolucionário, sobretudo, ao destruir o conceito tradicional de obra de arte). Nesse "meio-tempo", ocorreu uma perda considerável do efeito de choque e dos meios utilizados pelos vanguardistas, sendo que a retomada dessas intenções já não era mais plausível em um contexto modificado. Esses meios da vanguarda adquiriram status de arte, não sendo mais possível o seu uso para a integração total da arte com a vida. Em suma, "a neovanguarda institucionaliza a vanguarda como arte e nega, com isso, as genuínas intenções vanguardistas" (BÜRGUER, 2008, p. 109).

A existência de um forte aparato institucional, formado por críticos especializados, galerias, museus de arte, e um mercado consumidor dá sedimento a uma negociação entre o artista e sociedade, neutralizando as premissas mais radicais das vanguardas. Nesse sentido, Bürguer enxerga com desconfiança os movimentos experimentais da década de 1960, denominado neovanguardas, cujos protestos seriam blindados por uma instituição preparada para a sua assimilação.

Em sentido oposto a Bürguer, Hal Foster (2014) busca no "retorno das vanguardas" um lugar de volta à uma consciência crítica similar à das vanguardas históricas, em que as neovanguardas se reconectam aos paradigmas do passado para abrir possibilidades presentes, inclusive, a dimensão social da arte. Nesse sentido, o papel exercido pelas neovanguardas não 
é de completar o projeto ou algum resquício inacabado das vanguardas, mas compreender ou "retornar" ao seu sentido crítico original. O autor sugere um intercâmbio temporal entre vanguardas históricas e a neovanguardas, "uma relação complexa de antecipação e reconstrução" (FOSTER, 2014, p. 31), em que há uma espécie de remodelamento das vanguardas para fins contemporâneos.

O objetivo da passagem por essas duas teorias não é exatamente o de ajustar o perfil de vanguarda para uma versão latino-americana, mas de compreender os desdobramentos das vanguardas no pós-guerra, quando observou-se um processo de emergência de novos artistas e movimentos. O desenvolvimento da vanguarda argentina esteve fortemente atrelado a ascensão de um novo modelo institucional, aberto pelo Di Tella. Dentro do circuito modernizador, essa instituição teve o papel de reconhecer e legitimar as diversas versões das novas vanguardas. $\mathrm{O}$ fato de as vanguardas terem um respaldo institucional e, a princípio, não introduzirem em seu programa questões que envolvessem uma tomada de consciência por mudanças políticas e sociais, houve, de fato, uma radicalização por transformações estéticas e uma ruptura com as linguagens convencionais. Podemos atribuir a essas primeiras transformações estritas ao campo estético um modo de preparar o terreno para as transformações mais radicais que estariam por acontecer, onde as instâncias políticas e sociais adentraram com força total no circuito artístico, sobretudo, após 1966, com o golpe de estado do general Onganía.

Por meio da elaboração de formas atualizadas também acreditava-se que a etiqueta “internacional” estaria cada vez mais próxima da nova arte argentina, produção que já não era mais considerada uma cópia anacrônica e atrasada, mas a expressão da mais absoluta vanguarda que se realizava ao mesmo tempo e com a mesma carga de originalidade que nos centros tradicionais de criação artística (GIUNTA, 2008, p.241). Nesse sentido, o comentário de Guido Di Tella torna-se esclarecedor para compreender que o respaldo institucional pela renovação das linguagens causou um certo efeito de sincronismo das produções, acelerando cada vez mais os resultados do internacionalismo:

Hicimos impresionismo cuando este había terminado en Europa; hicimos cubismo un par de décadas más tarde, pero hicimos arte geométrico poco después y algunos dicen que un poco antes que en Europa; informalismo dos 
o tres [meses] después y el movimiento pop dos o tres horas después. ${ }^{64}$ (DI TELLA apud KING, 1985, p. 27).

Os impulsos pioneiros do movimento pop surgiram na Inglaterra no final da década de 1950 e se referiam a um extenso repertório icônico advindo de uma crescente cultura urbana de massas. Envolviam imagens de publicidade, fotonovelas, comics, televisão, cinema e outros meios de comunicação. Contudo, a experiência pop se consolidou nos EUA, ao encontrar total identificação com os valores dessa sociedade. Representavam as novas relações com a produção industrial e capitalista, aderindo a seu sistema e aos ícones publicitários e mercantis.

\begin{abstract}
A imagem pop refere-se diretamente à perda de originalidade, ligando-se, ao contrário, à estereotipia. No mundo do consumo, com a produção em série $\mathrm{e}$ a propaganda, não se tem mais o singular, mas o múltiplo. [...] A partir de uma visão, ao mesmo tempo cínica e trágica do american way of life, a arte pop reviu e comentou com distanciamento o modus vivendi das sociedades pós-industriais [...] sem romantismo ou heroísmo (CANONGIA, 2005, p. 4445).
\end{abstract}

O desenvolvimento da arte pop na Argentina assimilou principalmente a iconografia urbana e publicitária das versões internacionais, contudo, não incorporou o sentido trágico da aparente felicidade movida pelo consumo das sociedades desenvolvidas. Do lado de cá, o panorama da década de 1960 era favorável, embalado pelo crescimento econômico e o aumento do consumo; e seu correlato no campo das artes visuais, condicionado pela internacionalização da arte argentina, sobretudo na crença da recepção da produção local no circuito de grandes renomes internacionais, possibilitou um breve e inédito ânimo no âmbito cultural. O pano de fundo da assimilação instantânea da arte pop na Argentina se encontrou em mútua relação com a onda de entusiasmo pela qual o país passava, "Porque al desarrollarse la economía se enriquece la economía y se flexibiliza la conducta, bases de la verdadera conciencia artística y por tanto de la felicidade" (BREST apud TRABA, 2005, p. $196)^{65}$. Romero Brest, o maior entusiasta do movimento no circuito local, contribuiu com o desenvolvimento da nova geração pop argentina, desde o apoio institucional ao impacto

\footnotetext{
64 "Fizemos impressionismo quando este havia terminado na Europa; fizemos cubismo um par de décadas mais tarde, mas fizemos arte geométrica um pouco depois e alguns dizem que um pouco antes que na Europa; informalismo dois ou três [meses] depois e o movimento pop duas ou três horas depois." (tradução nossa).

65 "Porque ao desenvolver a economia se enriquece a economia e se flexibiliza a conduta, bases da verdadeira consciência artística e portanto da felicidade [...]." (tradução nossa).
} 
massivo que o movimento rapidamente adquiriu. A obra La Menesuda ${ }^{66}$, de Marta Minujín, por exemplo, transformou-se em um grande espetáculo com filas diárias de quase 3 mil pessoas que tomaram a rua Florida, sede do Di Tella. Esse resultado evidenciava o poderoso respaldo institucional de Brest e do CAV ao introduzir obras e grandes mostras em um circuito espetacularizado, que poderiam percorrer outras instituições sem produzir tamanha reação.

A obra era composta por vários ambientes: para acessar a primeira sala, o visitante passava por uma enorme porta com luzes de néon que o levaria a um circuito fechado de televisores que refletiam os seus movimentos. No outro quarto, uma cama matrimonial com um casal deitado, e no próximo, uma cabeça feminina gigante com vários cosméticos que poderiam ser usados por outras mulheres dentro de outro ambiente no interior da cabeça. Assim acessava outras salas que simulavam desde um pântano por onde passaria com dificuldade a um lugar onde precisaria sair acertando o número correto das teclas de um telefone gigante. Depois, transitaria pelo interior de uma geladeira que os conduziria até um ambiente repleto de espelhos e papeis picados que voavam com o vento produzido por um sistema de ventiladores. E desse modo finalizava a vivência ao voltar às salas padronizadas do Di Tella.

O escândalo e as polêmicas geradas em torno dessa obra representam o tipo de recepção que as novas vanguardas tiveram, especialmente a pop art e a ampliação das linguagens artísticas que ela desencadeou, criando um inédito campo de tensões no recente circuito moderno das artes plásticas portenha. "Es un capricho. Es realmente un disparate. Pero ES ARTE. Rescata a la gente del tiempo. Es el espetáculo del futuro. Basta de cuadros inmóviles!". ${ }^{67}$ Dessa forma, Minujín buscava delinear os diversos sentidos de La Menesuda ao provocar "situações" inesperadas nos participantes, propondo a ampliação de vivências extra-sensoriais que envolviam música, experiências táteis e a inserção de um elemento novo: a televisão, meio de comunicação de massa que ingressava na lista de consumo dos cidadãos portenhos e sobre a qual se "inscreviam novas matrizes da cultura popular". Havia um jogo duplo entre a cultura urbana relacionada com o imaginário portuário e da prostituição com os novos meios de comunicação (GIUNTA, 1994, p. 100).

\footnotetext{
${ }^{66}$ La Menesuda foi realizada por Marta Minujín e Rubén Santantonín, com a colaboração dos artistas Pablo Suárez, David Lamelas, Rodolfo Prayon, Floreal Amor e Leopoldo Maler, em 1965.

67 “É um capricho. É realmente um disparate. Mas É ARTE. Resgata a gente do tempo. É o espetáculo do futuro. Basta de quadros imóveis!” (tradução nossa). Careo, 2 jun. 1965. Arquivo Instituto Torcuato Di Tella.
} 
“Un lamentable espetáculo [...] para espantar al buen burgués. Algo para locos o tarados. No parece resultar estimulante sino, muy por el contrario, enervante". ${ }^{68}$ Diversos periódicos bombardearam as experiências propostas por La Menesuda, demonstrando uma total incompreensão das novas estratégias abertas pelas ações ambientais que transcendiam a obra aurática e os modos convencionais de contemplação. A obra simbolizava uma controvérsia fundamental e a crítica do jornal Le Quotidien, Germaine Derbecq ${ }^{69}$, conseguiu enxergar as consequências férteis geradas por esse campo artístico em transformação onde “[...] suscitar controvérsias é permitir a coordenação de pontos de vista distintos, o que contribui para ampliar a visão, e isso é muito importante". 70

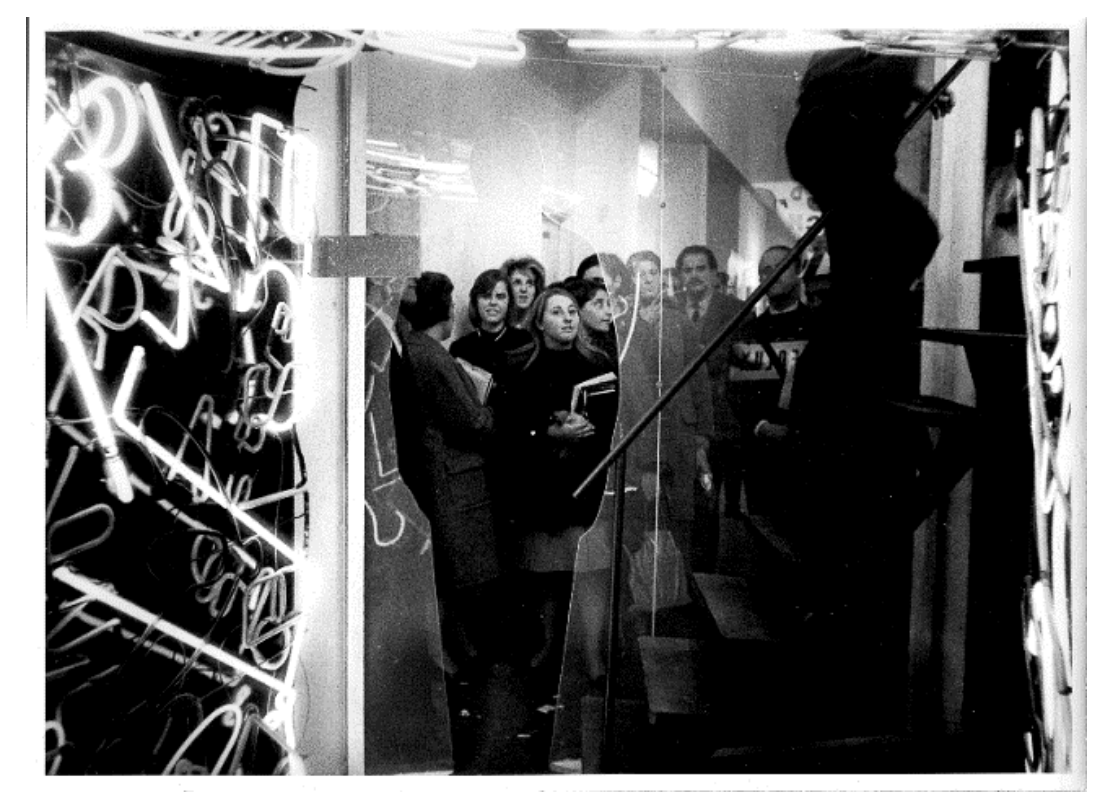

\footnotetext{
${ }^{68}$ Os respetivos trechos foram retirados de matérias dos jornais: La Gaceta, 2 de junho de 1965; Careo, 2 de junho de 1965; La Prensa, 30 maio 1965. (Arquivo Instituto Torcuato Di Tella). "Um lamentável espetáculo [...] para espantar o bom burguês. Algo para loucos ou tarados"; ou uma obra que "não parece resultar estimulante, mas, muito pelo contrário, irritante." (tradução nossa).

${ }^{69}$ Germaine Derbecq também era dona da Galeria Lirolay, referência fundamental no circuito das novas vanguardas portenhas.

${ }^{70}$ [...] Suscitar controversias es permitir la coordinación de puntos de vista distintos, lo que contribuye a ampliar la visión, y esto es muy importante." (tradução nossa).
} 


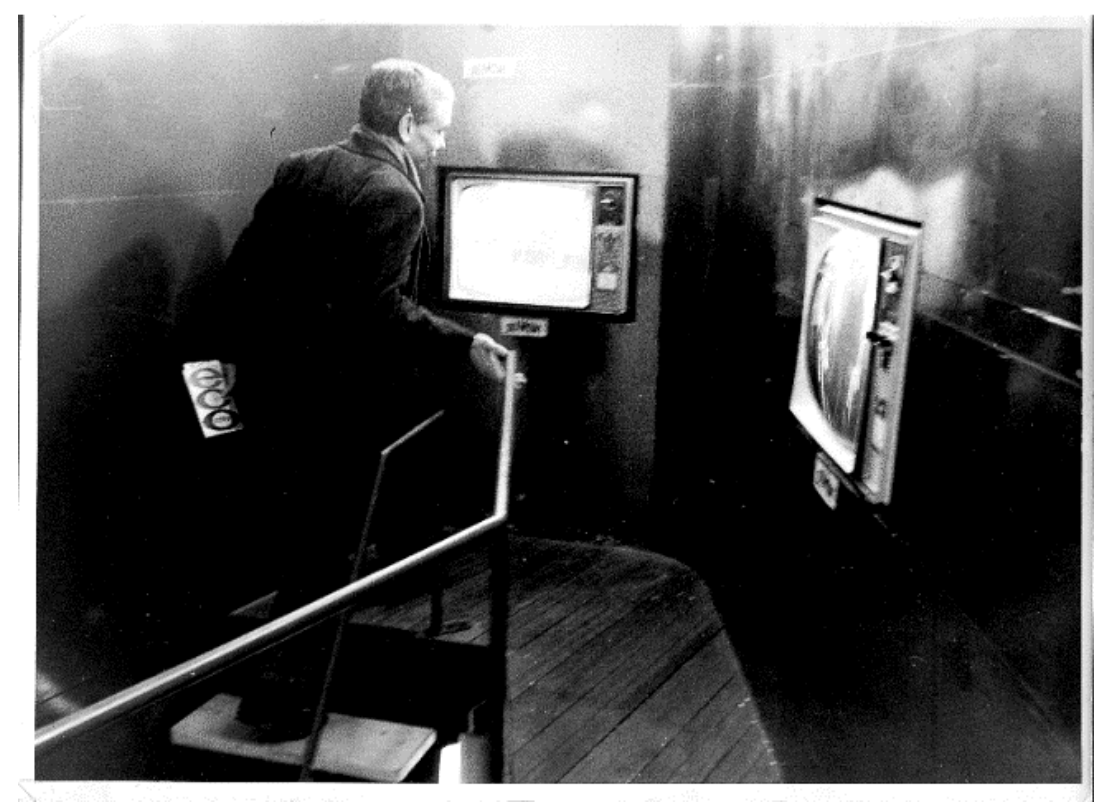

Figuras 17 e 18 - La Menesuda, Marta Minujín e Rubén Santantonín, 1965 (Arquivo Instituto Torcuato Di Tella)

A experiência pop argentina não foi homogênea e produziu um conjunto de obras e projetos que mesclavam desenho, publicidade, moda, teatro, histórias em quadrinhos com pintura e escultura. Muitos artistas trabalharam com conceitos de ruptura e provocação, gerando propostas dissonantes das noções convencionais de arte, ao se aproximarem dos fenômenos massivos. O imenso outdoor, de 1965, feito pelos artistas Edgardo Giménez, Carlos Squirru e Delia Puzzovio, é representativo para avaliar a realização de obras para os meios de comunicação, simulando um distanciamento, ainda que momentâneo, dos circuitos artísticos. A ocupação das ruas e espaços não tradicionais de exposição foi uma estratégia desses artistas, que buscavam essa breve saída a partir da apropriação de recursos típicos da linguagem publicitária. A pergunta ¿Por qué son tan geniales? aparecia acima da imagem dos três artistas que posavam sorridentes, irradiando alegria e juventude, além de propagar um estilo de vida em compasso com as promessas de um país em ascensão. "Se ofereciam entre irônicos e satisfeitos com a modernidade internacional dos sixties" (HERRERA, 2010, p. 32), manifestando a arte de um novo modelo cultural da sociedade de consumo.

Felicidade, diversão, moda, glamour e criatividade formavam o inventário dos jovens artistas da pop argentina, que também se aventuraram na área de desenhos de roupa, cenografia de peças de teatro, objetos decorativos e anúncios comerciais. Ocorreu um inédito embaralhamento de imagens de repertório erudito com um mundo transmissor de códigos da cultura de massa e dos meios de comunicação, suscitando uma rede de difusão de imagens de diferentes matrizes que se justapunham. Assim: 
La moda fue fantasía, imaginación, comunicación, volcada a un cuerpo que denunciaba los estereótipos de la identidade sexual. La vida cotidiana, el amor, la muerte y el "mundo feminino" - mito nacido de las radionovelas [...] elevaran al status de grandes temas. Realidades que existían y no habían sido antes señaladas (HERRERA, 2010, p. 5-6). ${ }^{71}$

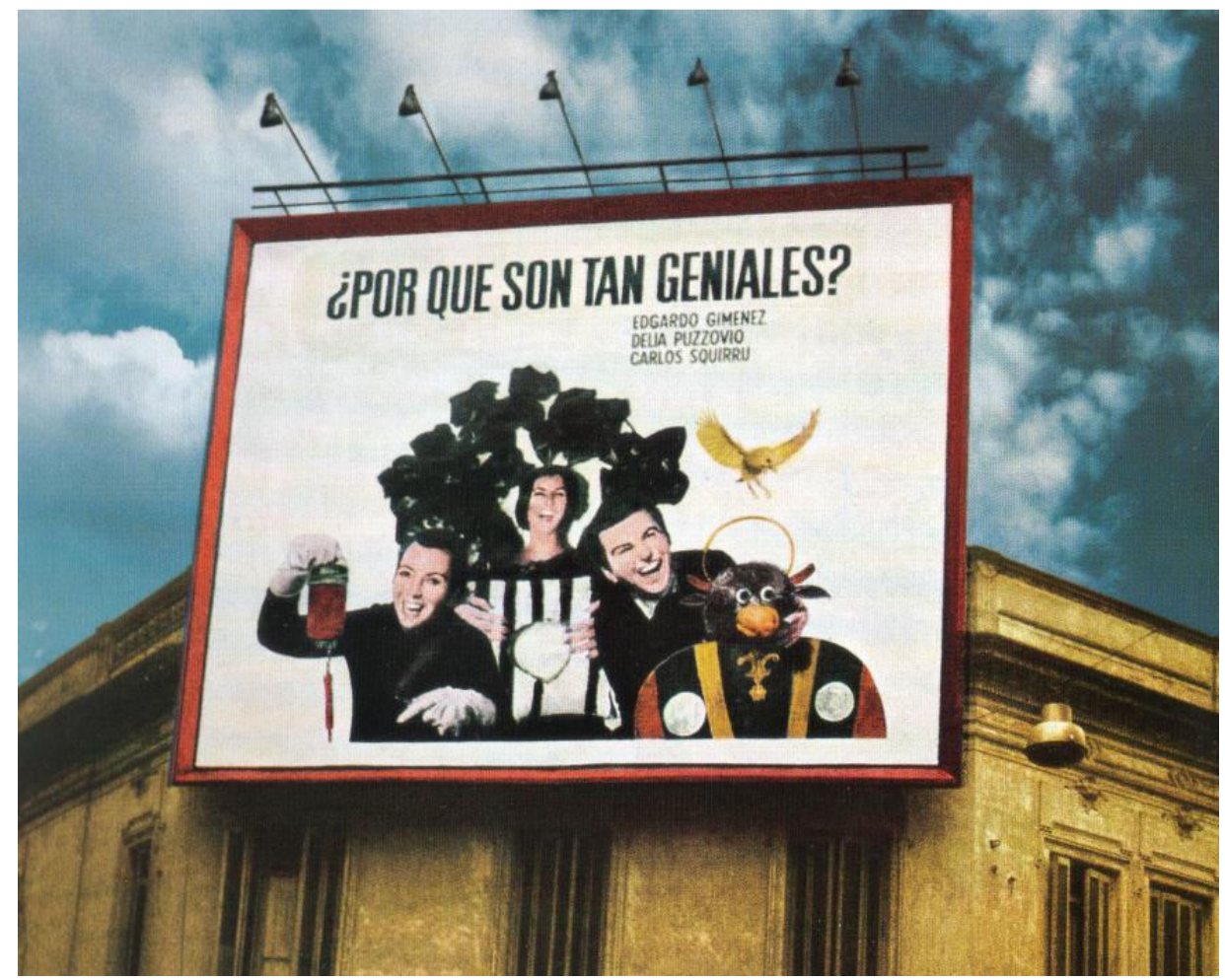

Figura 19 - ¿Por qué son tan geniales?

Edgardo Giménez, Carlos Squirru e Delia Puzzovio, 1965

O uso da própria imagem foi uma prática comum que apontava mais uma vez para as referências da publicidade. A utilização da autoimagem, frequentemente em dimensões monumentais e a criação de personagens similares ao do mundo dos comerciais, constituíamse como tática de incorporação lúdica e irônica dos ícones da indústria cultural da época. E como a linguagem da propaganda, as obras eram diretas e acessíveis à compreensão de todos. Uma arte popular, uma “[...] Arte que todo el mundo puede entender, arte feliz, arte divertido, arte cómico" (MINUJÍN apud LÓPEZ, 1997, p. 295) ${ }^{72}$, cujo otimismo fundado na felicidade do consumo tornava-se promessa de transformar a vida. E a moda era assumida como um paradigma importante dessa transformação, fundada na ideia de estetização da vida, aproximando arte e vida. Marta Traba leu com maus olhos as experiências do grupo pop

\footnotetext{
71، A moda foi fantasia, imaginação e comunicação, voltada a um corpo que denunciava os estereótipos da identidade sexual. A vida cotidiana, o amor, a morte e o "mundo feminino" - mito nascido das radionovelas [...] se tornaram grandes temas. Realidades que existiam e não haviam sido sinalizadas antes." (tradução nossa).

72 “[...] arte que todo mundo possa entender, arte feliz, arte divertida, arte cômica." (tradução nossa).
} 
argentino, caracterizado, segundo a crítica, por sua "dedicação ao espetáculo e sua paixão pelo escândalo" (1977, p. 127). Ao serem absorvidos pelo Di Tella e trabalharem dentro de sua órbita, os "meninos e meninas terríveis" praticaram a "revolução de uma quadra", ou seja, não foram além das ruas Florida, Charcas e Paraguai (1977, p. 127)

O Prêmio Nacional Di Tella ${ }^{73}$ de 1966 reuniu uma série de artistas da tendência pop nacional. Vale lembrar que no mesmo ano, alguns meses antes da abertura, os portenhos haviam entrado em contato com os nomes mais destacados da pop art internacional por meio da exposição 11 artistas Pop: la nueva imagen ${ }^{74}$. A presença de Restany em 1964 também foi fundamental para divulgar as bases desse movimento, principalmente o Novo Realismo francês em Buenos Aires. A maior parte das obras expostas no Prêmio sintetizava a assimilação do estilo internacional sobreposto a uma herança local, cruzando elementos da realidade com a esfera artística.

Podemos identificar no autorretrato da artista Dalila Puzzovio uma fusão do imaginário pop apresentado na ocasião. A artista retomava as temáticas da publicidade gráfica ao exibir um retrato de grandes dimensões pintado por artesãos de cartazes de cinema. Puzzovio aparecia deitada de biquíni em uma praia, como em um anúncio de roupas de banho. Distinto da tradição de autorretratos realistas, a artista se mostrava com um corpo idealizado, interpretando uma personagem típica do mundo das propagandas, de imagem sedutora e dócil. O imenso cartaz era rodeado por lâmpadas amarelas semelhantes às usadas em espelhos de camarim.

O crítico inglês Lawrence Alloway foi um dos jurados da mostra e a pedido de Romero Brest, escreveu um texto para o catálogo do Prêmio:

Buenos Aires há sido desde hace algunos años una ciudad con una importante actividad de los artistas Pop y con un potencial mayor aún. [...] Es claro que con el Premio Di Tella 1966 ahora es uno de los más vigorosos

\footnotetext{
73 Devido à redução de verbas, a versão de 1966 teve o regulamento modificado e contou apenas com a participação de artistas nacionais. A instituição cortou a recompensa de bolsas para o exterior e estabeleceu a entrega de prêmios em dinheiro para os dois primeiros colocados, além da aquisição das obras premiadas. Os jurados foram Otto Hahn, Lawrence Alloway e Romero Brest. As artistas premiadas foram Susana Salgado, com a obra Girasoles, e Dalila Puzzovio, com um autorretrato.

${ }^{74}$ Realizada pela Philip Morris International, com os auspícios da Embaixada dos EUA na Argentina. Fizeram parte da exposição os artistas Alla D'Arcangelo, Jim Dine, Allen Jones, G. Laing, Roy Lichtenstein, Peter Phillips, Mel Ramos, James Rosenquist, Andy Warhol, John Wesley e Tom Wesselmann. (BREST, 1992, p. 98)
} 
Centros del Pop Art en el mundo. (LAWRENCE apud BREST, 1992, p. $104-105)^{75}$

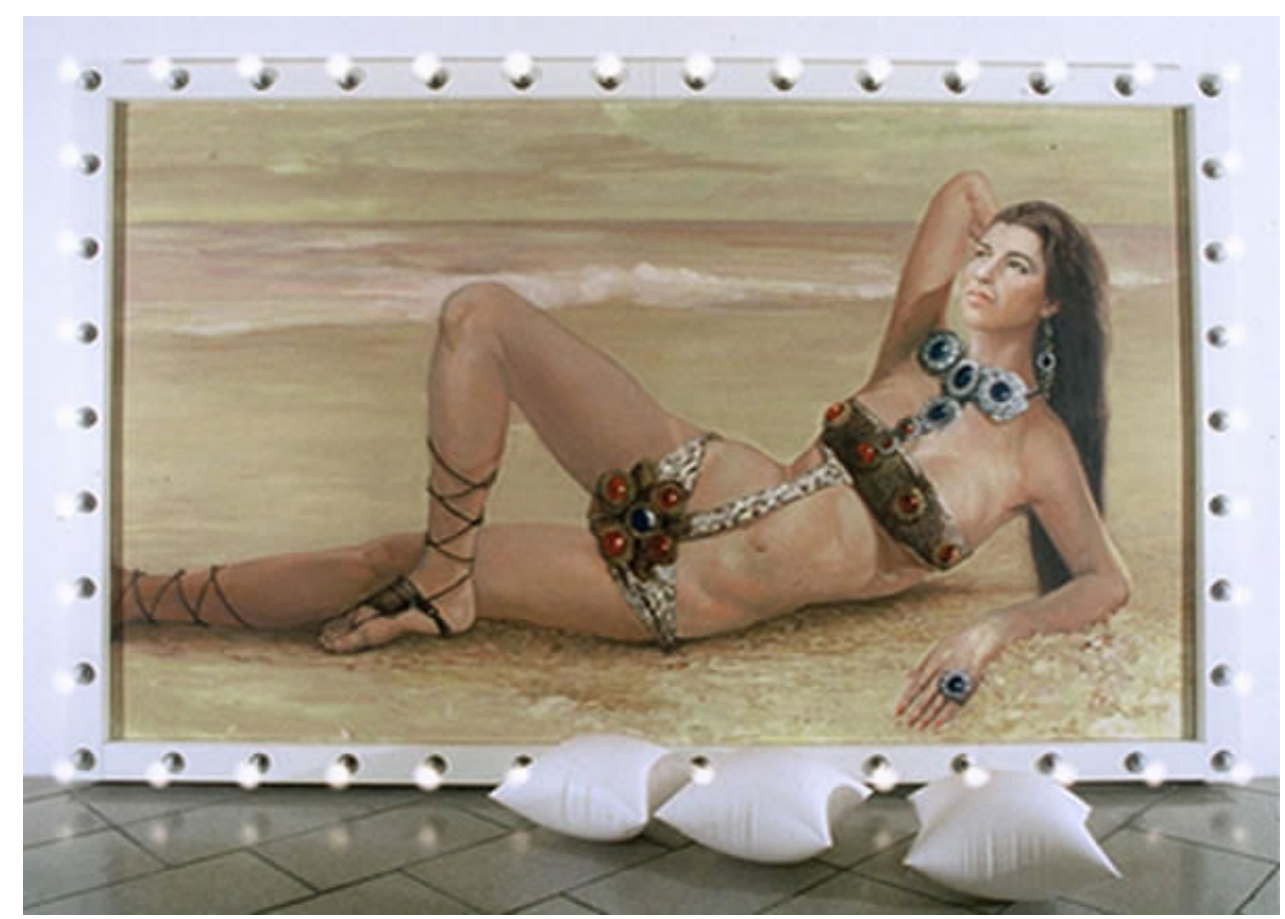

Figura 20 - Autorretrato, Dalila Puzzovio Técnica mista, objetos e luz, 223 x 365,5 x $100 \mathrm{~cm}, 1966$

Notamos no texto de Alloway um certo exagero em situar o Di Tella no eixo das principais instituições de arte pop do mundo. A tendência, ou ainda, algumas particularidades do movimento foram presenciadas apenas dois anos antes do Prêmio de 1966, com a obra Revuélquese y viva!, de Marta Minujín. E no decorrer desses dois anos, a pop argentina foi circunscrita a um pequeno grupo de artistas ligados ao Di Tella. Essas manifestações foram anunciadoras de transformações futuras no campo artístico local, contudo, tiveram pouca ou quase nenhuma relevância no âmbito internacional. Se os primeiros rastros da pop na Argentina apareceram "duas ou três horas depois" da Europa e EUA, como escrevera Siam Di Tella ao enfatizar o sincronismo e originalidade da produção local, o movimento perdeu fôlego rapidamente. Em 1967, Romero Brest publicou o ensaio Relación y reflexión sobre el pop art, no qual buscava debater sobre a manifestação dessa tendência, estabelecendo uma relação incomum entre as obras gregas clássicas e a cultura pop, pois em ambos os momentos

\footnotetext{
75 "Buenos Aires tem sido há alguns anos uma cidade com uma importante atividade de artistas pop com um grande potencial. É claro que o Prêmio Di Tella 1966 agora é um dos mais vigorosos centros de pop art do mundo. [...] A arte pop argentina tem uma nova claridade e poder." (tradução nossa).
} 
poderia se observar "o essencial de certas realidades". No final de sua reflexão, Brest indicava o destino da arte pop nacional:

¿Y en nuestro país? El pop art se pareció al principio más al de Europa que al de los Estados Unidos, pero las consecuencias han sido distintas, no sólo porque los creadores de por aqui dejaron de ser pop rapidamente, sino porque derivaron hacia el "arte de los medios" y las "experiencias visuales". Ni Minujín, ni Puzzovio, ni los Cancela-Mesejean, ni Rodríguez Arias o Stoppani, son pop en la actualidad. (BREST apud KATZENSTEIN, 2007, p. $131)^{76}$

O acelerado desenvolvimento da arte pop abarcou as temáticas relacionadas ao imaginário urbano; a realização de obras de dimensões monumentais se desdobrou na produção de arte ambiental, obras interativas, efêmeras e a prática de happenings. Os happenings expressavam uma nova forma de ver a arte. A obra já não existia em si mesma, era um momento criativo compartido entre os artistas e os espectadores criando um universo amplo de significações. Contudo, o happening seguiu um caminho distinto de sua variante internacional, atrelando-se aos meios de comunicação de massa e às estruturas de transmissão dos conteúdos.

A historiografia de arte argentina considera Oscar Masotta como um dos mais importantes teóricos da arte pop e do happening do país. O teórico organizou uma série de conferências no Di Tella sobre as novas tendências como Arte pop y semântica, em 1965 e Después del pop, nosotros desmaterializamos, em 1967. Na mesma época publicou os livros Pop Art e Happenings, sendo o último uma compilação de textos do autor e outros artistas sobre a repentina explosão do termo nos meios de comunicação, uma vez que até aquele momento o gênero havia sido manifestado raras vezes no país. A reflexão se baseava no uso indevido da terminologia pela imprensa, que publicava inúmeras matérias sem um entendimento mais profundo sobre o assunto. Frequentemente os happenings mencionados pelos jornais nem sempre correspondiam aos eventos efetivamente realizados, gerando uma rede de informações incorretas no interior desses meios. E para Masotta, a principal matériaprima da pop art e do happening era aquela advinda dos meios de comunicação.

\footnotetext{
76 “E em nosso país? A pop art se pareceu a princípio mais com a da Europa do que com a dos Estados Unidos, mas as consequências têm sido distintas, não só porque os criadores daqui deixaram de ser pop rapidamente, mas porque derivaram para uma "arte de los medios" e as "experiecias visuales". Nem Minujín, nem Puzzovio, nem os Cancela-Mesejean, nem Rodríguez Arias ou Stoppani, são pop na atualidade. ”(tradução nossa).
} 
[...] El bronce, o la madera, o el mármol [...] constituyen la "materia" con la cual y sobre la cual es possible hacer esculturas, las "obras de comunicación" definen ellas también el área de su propria "materialidad". La "materia" con la que se construyen obras informacionales de tal tipo no es outra que los procesos, los resultados, los hechos y los fenómenos de la información masiva. Ej. de "medios": la radio, la televisión, los periódicos etc. (MASOTTA apud ALONSO, 2011, p 198) ${ }^{77}$

A materialidade, ou seja, a própria estrutura pela qual se veiculava as mensagens, tornara-se um ponto central na obra e na reflexão de alguns artistas. Em 1966, Eduardo Costa, Raúl Escari e Roberto Jacoby publicaram o manifesto Un arte de los medios de comunicación, sinalizando como os fatos poderiam ser construídos e distorcidos nos meios de comunicação. Os artistas realizaram um antihappening conhecido como Happening para un jabali difunto, Participación total ou El happening que nunca existió, que consistia em informar jornais e revistas sobre um happening que na realidade não havia ocorrido. No manifesto, os artistas escreveram:

Nosotros pretendemos entregar a la prensa el informe escrito y fotográfico de un happening que no ha ocurrido. Este falso informe incluirá los nombres de los participantes, una indicación del lugar y momento en que se realizo y una descripción del espetáculo que se finge que ha ocurrido, con fotos tomadas a los supuestos participantes en otras circunstancias. [...] Llevamos así hasta su última instancia una característica de los medios de comunicación: la desrealización de los objetos. (COSTA, ESCARI, JACOBY, apud ALONSO, 2011, p 70). ${ }^{78}$

O "complot" (GIUNTA, 2011. p. 55) dos artistas buscava construir a obra no interior dos meios, evidenciando que a transmissão de uma informação constituía o sentido do antihappenig, com a produção de uma realidade inexistente. Foram propostas que buscavam indagar as regras, os suportes e os efeitos na percepção gerados pela comunicação de massa, que no âmbito artístico argentino ganhou um novo gênero: a arte dos "mass media" ou uma arte dos meios de comunicação, de acordo com o manifesto. Quando e de que modo começa um processo comunicativo; onde se difunde uma mensagem e como a interpretam? Como os

\footnotetext{
77 "O bronze, ou a madeira, ou o mármore [...] constituem a "matéria” com a qual e sobre a qual é possível fazer esculturas, as "obras de comunicação" definem elas também a área de sua própria 'materialidade'. As 'matérias' com as quais se constroem obras informativas de tal tipo não são outras que não sejam os processos, os resultados, os fatos e os fenômenos de informação de massa. Exemplo de 'meios': o rádio, a televisão, os jornais, as revistas [...] etc." (tradução nossa).

78،"Propomos entregar à imprensa o informe escrito e fotográfico de um happening que não aconteceu. Este falso informe incluirá os nomes dos participantes, uma indicação do lugar e o momento em que se realizou e uma descrição do espetáculo que finge que ocorreu, com fotos tiradas dos supostos participantes em outras circunstâncias. [...] Levamos assim até a sua última instância uma característica dos meios de comunicação: a desrealização de objetos." (tradução nossa).
} 
meios de comunicação podem afetar a realidade? De que maneira esses aparatos tecnológicos afetam a percepção dos sentidos? Eram alguns dos pontos de reflexão para as intervenções artísticas, que também tiveram como base conceitual os textos do filósofo Marshall Mc Luhan, amplamente difundidos na época.

Desse modo, o valor tradicionalmente atribuído ao produtor era substituído pelos aspectos referentes à transmissão, circulação e recepção. (HERRERA, 1997, p. 371-372) 79 . Sobre a natureza forjada das informações, Herrera nos lembra do pânico gerado pela falsa notícia de Orson Welles, quando o cineasta difundiu pelo rádio a invasão de alienígenas na terra. Contudo, a autora diferencia o caráter de ambas as experiências, principalmente no que diz respeito à intencionalidade. No caso argentino, havia um marco bem definido na intenção de distorcer os fatos, que era a intervenção estética, na qual, por detrás de todas as operações de transmissão, se encontrava "a figura fantasmagórica do artista que intervém elegendo o dia em que conclui o processo desmentindo" as informações sobre a existência do happening. (HERRERA, 1997, p. 375-376) $^{80}$. O sociólogo Eliseo Verón escreveu sobre o fato:

Está enteramente fuera de mi capacidad evaluar esta experiencia desde el punto de vista estético, ignoro si puede ser classificada o no como un objeto artístico. De todas maneras, me permito aventurar, como predicción sociológica, la sospecha de que el arte de la sociedade postindustrial de futuro, será más semejante a esta experiencia que a una tela de Picasso, un arte cuya materia no sea física sino social. Objetos, en suma, que será difícil conservar en los museos para las geraciones posteriores (VERÓN apud GLUSBERG, 1985, p. 81) ${ }^{81}$.

As experiências produzidas por "uma arte cuja matéria não seja física, mas social”, de acordo com as palavras de Verón, marcaram gradualmente uma guinada à radicalização da arte e do abandono de linguagens e materiais tradicionais. Esse processo ficou conhecido como "a morte da arte" ou "desmaterialização da arte", que culminou em obras compostas por conteúdos políticos e conceituais advindos de diversas correntes artísticas que se desenvolveram rapidamente no final dessa década. Essas vanguardas plásticas incluíam

\footnotetext{
79 HERRERA, María José. La Experimentación con los medios masivos de Comunicación en el arte argentino de la década del sessenta: el "happening para un jabalí difunto". In: http://www.caia.org.ar/docs/Herrera.pdf. Acesso em 29-03-2015

${ }^{80}$ Ibidem.

81 “Está inteiramente fora da minha capacidade julgar esta experiência do ponto de vista estético, ignoro se pode ser classificada ou não como um objeto artístico. De toda maneira, me permito aventurar, como uma hipótese sociológica, a suspeita de que a arte da sociedade pós-industrial do futuro, será mais semelhante a esta experiência que a uma tela de Picasso, uma arte cuja matéria não seja física, mas social. Objetos, em suma, que serão difíceis de conservar nos museus para as gerações posteriores." t nossa).
} 
modalidades ligadas à pop art, happenings, ambientações, estruturas primárias, arte de los medios, experimentações com novas tecnologias etc. A inserção do artista como parte significante da obra e em muitos casos, o distanciamento da figura convencional do artista e da atribuição de sua autoria máxima e individual, transformaram sua função e lugar sociais. A arte se tornava cada vez mais afastada dos limites de sua autonomia. A pauta dos artistas já não buscava simbolizar ou representar a realidade; a realidade constituía-se como elemento das obras, lembrando que um dos aspectos dessa realidade naquele momento era o avanço da violência e da repressão dos regimes ditatoriais que se instalaram em diversos países da América Latina.

Desse modo, escolhemos a mostra Experiencias 68, organizada pelo Instituto Di Tella, em 1968, como momento deflagrador dessas transformações e como espaço de confrontação artística e política. Dois anos antes o general Juan Carlos Onganía chegava ao poder com a intitulada "Revolução Argentina", um golpe militar que alterou profundamente a realidade do país. A política cultural do regime se caracterizou por sua direção autoritária. A instauração da censura e da repressão policial como práticas cotidianas buscou sufocar não apenas as manifestações culturais vinculadas aos movimentos de esquerda, mas quaisquer formas de criação intelectual e artística que fugissem da ordem vigente. Sobre o ambiente de coerção, Oscar Masotta apontou: "Cuando se produce el golpe de estado que entroniza Onganía, hay um brote de puritanismo y de persecusión policial. Atemorizados, abandonamos proyectos."

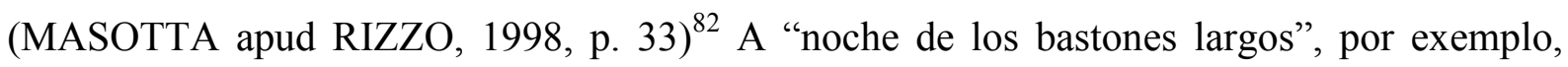
ficou conhecida pelo fechamento da Universidade, cujo espaço havia se mostrado altamente renovador e politizado. A sucessão de atos de censura incluiu o fechamento de publicações, salas de teatro, emissoras de rádio etc. A dimensão autoritária exercida pelo Onganiato foi gerando um campo heterogêneo de oposição formado por diversos grupos culturais que assumiram uma postura política mais radical diante do embrutecimento do governo ditatorial. Esses grupos representavam a emergência das chamadas "novas esquerdas" ou "esquerdas revolucionárias", forças sociais e políticas que ganharam corpo ao longo desses anos. A radicalização política desses setores se instaura em um momento conturbado no contexto internacional, no qual programas de revolução social fortaleciam a ideia do colapso do sistema capitalista com as Revoluções em Cuba e na Argélia, os movimentos de descolonização, a resistência vietnamita e em especial o maio francês (LONGONI;

\footnotetext{
82 "Quando se produz o golpe de estado conduzido por Onganía, há um surto de puritanismo e de perseguição policial. Aterrorizados, abandonamos projetos." (tradução nossa).
} 
MESTMAN, 2008, p. 37-38). Desse modo, o vento revolucionário produziu consequências políticas e culturais irreversíveis no contexto argentino, e o próprio golpe militar em 1966 surtiu uma espécie de efeito boomerang, uma influência também significativa na radicalização política de diversas formações culturais (2010, p. 40), incidindo sua órbita nas vanguardas artísticas. O Instituto Di Tella, como grande divulgador dessas vanguardas plásticas, também sofreu os embates da repressão com a intervenção policial da mostra Experiencias 68, como veremos a seguir, acirrando o debate político no âmbito artístico. 


\subsection{5 - EXPERIENCIAS 68: RUMO À RADICALIZAÇÃO POLÍTICA}

Experiencias $68^{83}$ foi considerada como a "epítome da experimentação e também das tensões do desenvolvimento cultural argentino no fim da década de 1960" (KING, 2007, p. 198), na qual encontravam-se diferentes tendências plásticas que exacerbavam cada vez mais os limites das linguagens artísticas. Podemos observar, também, uma crescente radicalização política dos artistas participantes e de algumas obras expostas, provocando a censura policial da mostra. Consequentemente, o agravamento causado por esses conflitos desencadeou uma ruptura no circuito artístico promovida pelas vanguardas artísticas que até então haviam sido promovidas pelo Di Tella, motivando uma postura anti-institucional por parte de vários artistas.

Em nota de divulgação da abertura da exposição, Brest escreveu:

Con "Experiencias 1968" y continuando en certo modo "Experiencias Visuales 1967", un grupo de jóvenes artistas intenta plantear el problema de la creación en términos casi extremos. [...] Presente una situación vital que no se aleja de las que tradicionalmente presentaban las "obras de arte" sino por la falta de representación em imagen. Como se quisieran acercar al arte a la vida - el mayor deseo de los artistas em toda época - superando el intermediario de forma-símbolo. [...] La palabra "experiencia" [...] es usada con intención definida, para indicar que no son estáticas "obras de arte" terminadas y definidas - sino proyectos de creación dinâmica para el contemplador. ${ }^{84}$

Os trezes ${ }^{85}$ artistas convidados apresentaram obras que evidenciavam o alargamento das fronteiras visuais do objeto tradicional "estático", expondo "experiências" que muitas vezes aludiam à preponderância da ideia sobre a representação, substituindo a materialidade habitual por propostas "dinâmicas" e abertas. A proposta de Brest era convocar os

\footnotetext{
${ }^{83}$ Experiencias 68 foi a continuação da mostra iniciada no ano anterior sob o título Experiencias Visuales 1967. Sobre ela, Brest escreveu: "la palabra 'experiencia' [...] indica lo que está sin terminar, sólo em vías de ejecución”. (BREST, 1992, p 125). O formato da exposição seguiu até 1969, com Experiencias 69. Vale citar que nesta última participaram Luis Pazos, Luis Fernando Benedit, Edgardo Antonio Vigo, entre outros, sendo os dois primeiros, artistas ligados ao CAYC e ao Grupo de los Trece.

"A palavra 'experiência" [...] indica o que está sem terminar, apenas em vias de execução." (tradução nossa).

${ }^{84}$ “Com 'Experiencias 1968' e continuando de certo modo 'Experiencias Visuales 1967', um grupo de jovens artistas buscam trabalhar o problema da criação em termos quase extremos. Diante de uma situação vital que não se distancia das que tradicionalmente se apresentavam as 'obras de arte', mas por falta de representação de imagem. Como se buscassem aproximar a arte da vida - o maior desejo dos artistas em toda época - superando o intermediário da forma-símbolo. [...] A palavra 'experiência' [...] é usada com intenção definida, para indicar que não são estáticas as 'obras de arte' - terminadas e definidas - mas projetos de criação dinâmica para o contemplador.” (tradução nossa). Arquivo Instituto Torcuato Di Tella.

${ }^{85}$ De acordo com a nota divulgada por Brest, os participantes eram: Rodolfo Azaro, Oscar Bony, Delia Cancela e Pablo Mesejean, Jorge Carballa, Roberto Jacoby, David Lamelas, Margarita Paksa, Roberto Plate, Alfredo Rodriguez Arías, Pablo Suárez, Juan Stoppani e Antonio Trotta. Arquivo Instituto Torcuato Di Tella.
} 
espectadores a vivenciar diversas "experiências" que relacionavam imagem e palavra, obras cuja natureza era desaparecer não enquanto arte, mas como aspecto (BREST, 1992, p. 128).

A exposição iniciou com a renúncia de um dos artistas convidados, Pablo Suárez, que decidiu realizar sua obra às margens da instituição. Suárez escreveu uma carta a Romero Brest justificando os motivos de sua desistência gerados pela crescente desconfiança em relação à centralização cultural exercida pelo Di Tella frente à situação política e social do país. O artista definiu a carta como "uma obra", "um fato estético", tornando pública a sua renúncia com a distribuição da correspondência na entrada da instituição e ao redor da rua Florida, durante os dias em que a exposição esteve aberta. A atitude anti-institucional demonstrava o descontentamento com o circuito artístico hegemônico e a institucionalização da arte, pois:

"la institución sólo deja entrar produtos ya prestigiados a los que utiliza" e "[...] impide la difusión masiva de las experiencias que puedan realizar los artistas. [...] Esta renuncia es una obra para el Instituto Di Tella. Creo que muestra claramente mi conflicto frente a esta invitación, y por lo tanto haber cumplido con el compromiso." ${ }^{, 6}$

Roberto Jacoby resolveu estabelecer sua crítica institucional dentro do próprio CAV, expondo um cartaz intitulado Mensaje en Di Tella, que formulava os problemas da vanguarda amparada pelo Instituto, movida apenas pelo "interesse econômico, prestígio ou a estupidez". A mensagem situava a importância da justaposição entre arte e vida e dos fenômenos da vida social que tinham se convertido em matéria estética, como a comunicação, por exemplo. E julgava o público que acreditava buscar no Di Tella um "banho de cultura".

A obra se complementava com uma fotografia de um homem negro em uma manifestação contra a guerra do Vietnã e o racismo nos EUA, segurando um papel com os dizeres: "Também sou um homem"; aludindo na mesma imagem ambos os conflitos. Havia, também, um teletipo da agência France-Prese que transmitia em tempo real notícias da França. Curiosamente, o período da exposição, maio de 1968, foi o mesmo da eclosão estudantil francesa, e o teletipo acabou divulgando informações simultâneas aos acontecimentos na Europa. Essa obra, de certa forma, dava sequência à ideia desenvolvida anteriormente pelo artista, denominada arte de los medios, ao mencionar os conteúdos ideológicos dos meios de comunicação, que, no caso desta obra, era explicitada pelas três

\footnotetext{
86 "a instituição apenas deixa entrar produtos já prestigiados a quem os utiliza" e "[...] impede a difusão massiva das experiências que os artistas possam realizar. [...] Esta renúncia é uma obra para o Instituto Di Tella. Creio que mostra claramente o meu conflito frente a este convite e assim cumpro com o compromisso." (tradução nossa). Arquivo Instituto Torcuato Di Tella.
} 
mensagens: a do jovem negro, a dos veículos de comunicação e a do próprio artista. De acordo com Jacoby:

“[...] los tres mesages tienen en común un contenido explícitamente ideológico. Quiero señalar que los contenidos, explícitamente ideológicos o sociales, poseen en la conciencia de los receptores una realidade material. Asi como se trabaja con materiales diversos (pintura, yeso, madera), es posible trabajar com contenidos ideológicos. Com estructuras sociales de Comunicación. [...]”87 (JACOBY apud RIZZO, 1998, p. 56)

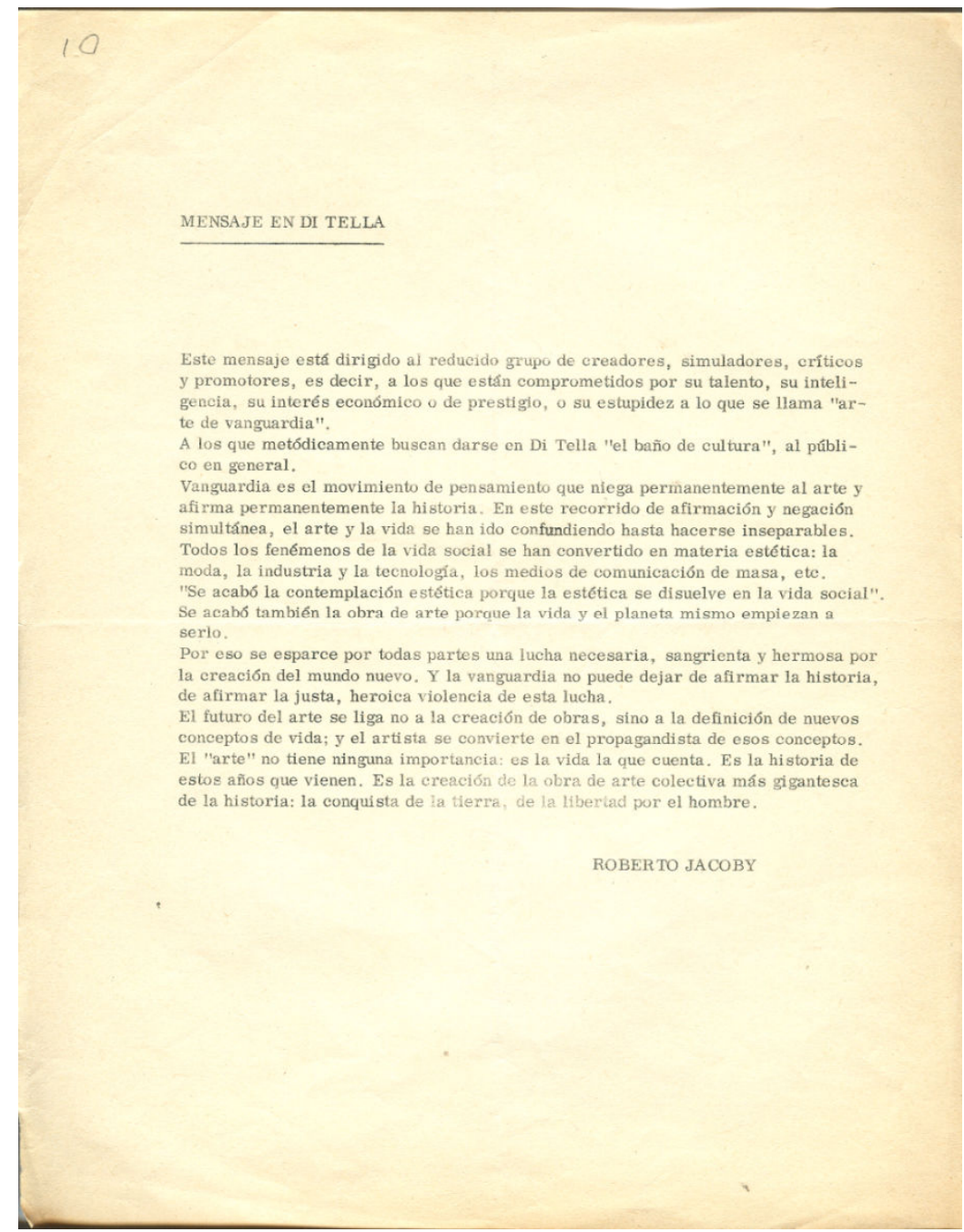

Figura 21 - Mensage en Di Tella, Roberto Jacoby, 1968

Arquivo Instituto Torcuato Di Tella

87 “[...] As três mensagens têm em comum um conteúdo explicitamente ideológico. Quero sinalizar que os conteúdos, explicitamente ideológicos ou sociais, possuem na consciência dos receptores uma realidade material. Assim como se trabalha com materiais diversos (pintura, gesso, madeira), é possível trabalhar com conteúdos ideológicos. Com estruturas sociais de comunicação [...]." (tradução nossa). 
Termos como "un trance agónico", "un suicidio estético" ou "la muerte de la pintura" ${ }^{\prime 88}$ circularam em jornais da época e apontavam para uma busca de entendimento suscitada por essas experiências, que além de lidar com o tema do desaparecimento da arte tradicional, decretavam a superação dos limites da arte e a sua inclusão irreversível na esfera da vida. As propostas de Suárez e Jacoby levavam a cabo essa pauta cada vez mais emergente, reivindicando, cada um a seu modo, novas alternativas frente ao esgotamento do circuito modernizador em vigência, representado pelo Di Tella.

Outra obra que gerou polêmicas foi La familia obrera, de Oscar Bony. Tratava-se de uma família sentada sobre um pedestal acompanhada de sons captados do cotidiano e do lugar no qual vivia. Esse grupo permaneceu sentado durante toda a exposição, no meio da sala do $\mathrm{CAV}$, simulando uma rotina que incluía comer, fumar, ler, conversar etc., causando o espanto do visitante, que em alguns casos, tentava convencer a família a abandonar aquela função expositiva e degradante. Sobre o pedestal, o artista havia colocado um pequeno cartaz com a seguinte informação: “Luis Ricardo Rodríguez, matricero de profesión, percebe el doble de lo que gana en su oficio, por permanecer en exhibición con su mujer y su hijo durante la muestra". 89

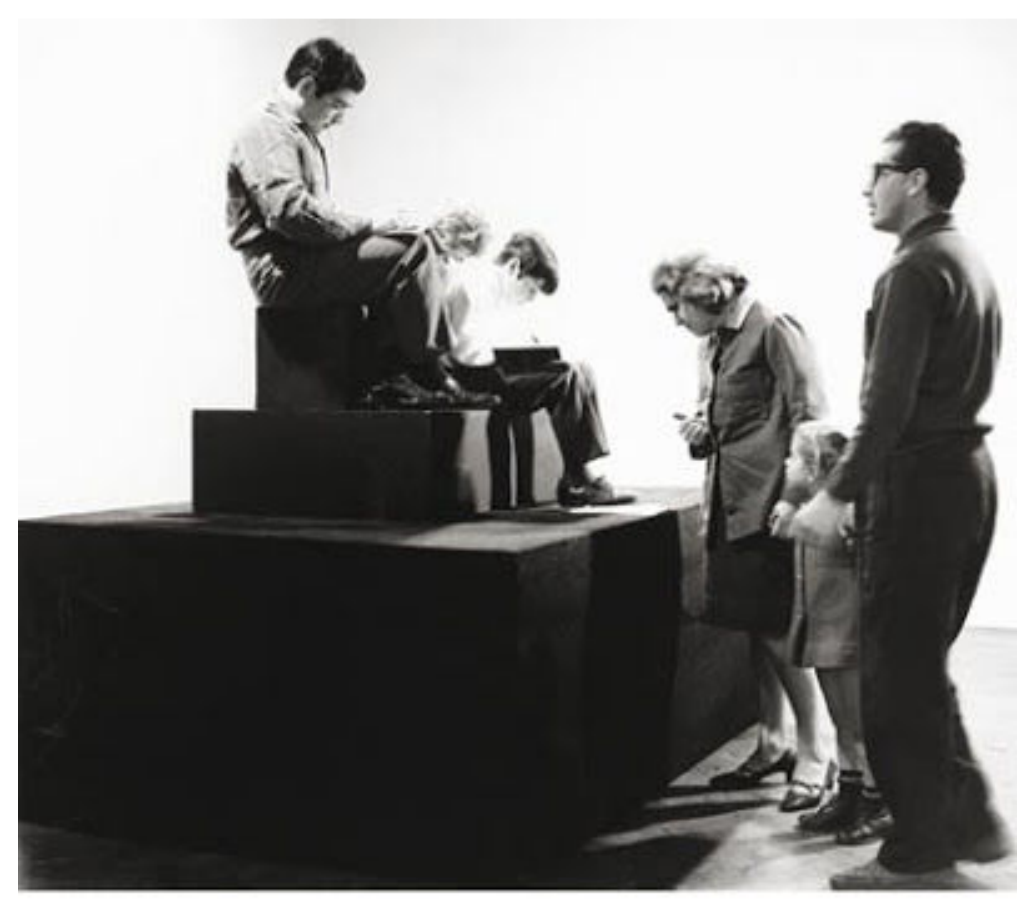

Figura 22 - Familia obrera, Oscar Bony. Instalação, 1968.

\footnotetext{
${ }^{88}$ Na sequência: Primera Plana n. 283, 28 de maio de 1968. Primera Plana n. 282, 21 de maio de 1968. Primera Plana n. 333, 13 de maio de 1969. (Arquivo Instituto Torcuato Di Tella). "Um transe de agonia". "Um suicídio estético". "A morte da pintura." (tradução nossa).

89 "Luis Ricardo Rodríguez, mecânico de profissão, recebe o dobro que ganha em seu trabalho, por permanecer em exposição com sua mulher e filho durante a mostra." (tradução nossa).
} 
Os jornais qualificaram a obra como um atentado aos valores do trabalho e da família, causando indignação, também, em alguns artistas que a consideraram humilhante para a família operária (LONGONI; MESTMAN, 2008, p. 109).

Algumas obras mostraram menos controvérsias ao público e crítica, como foi o caso das apresentadas por David Lamelas e Antonio Trotta. Desdobramentos da arte cinética e de estruturas primárias, eram trabalhos que buscavam uma experimentação mais formal. $\mathrm{O}$ primeiro projetou diversas lanternas cujas luzes incindiam sobre uma parede com diferentes texturas: ora lisa, ora rugosa. O segundo mostrou um esquema de formas retangulares em série com dois espelhos que refletiam o público simultaneamente de frente e de costas.

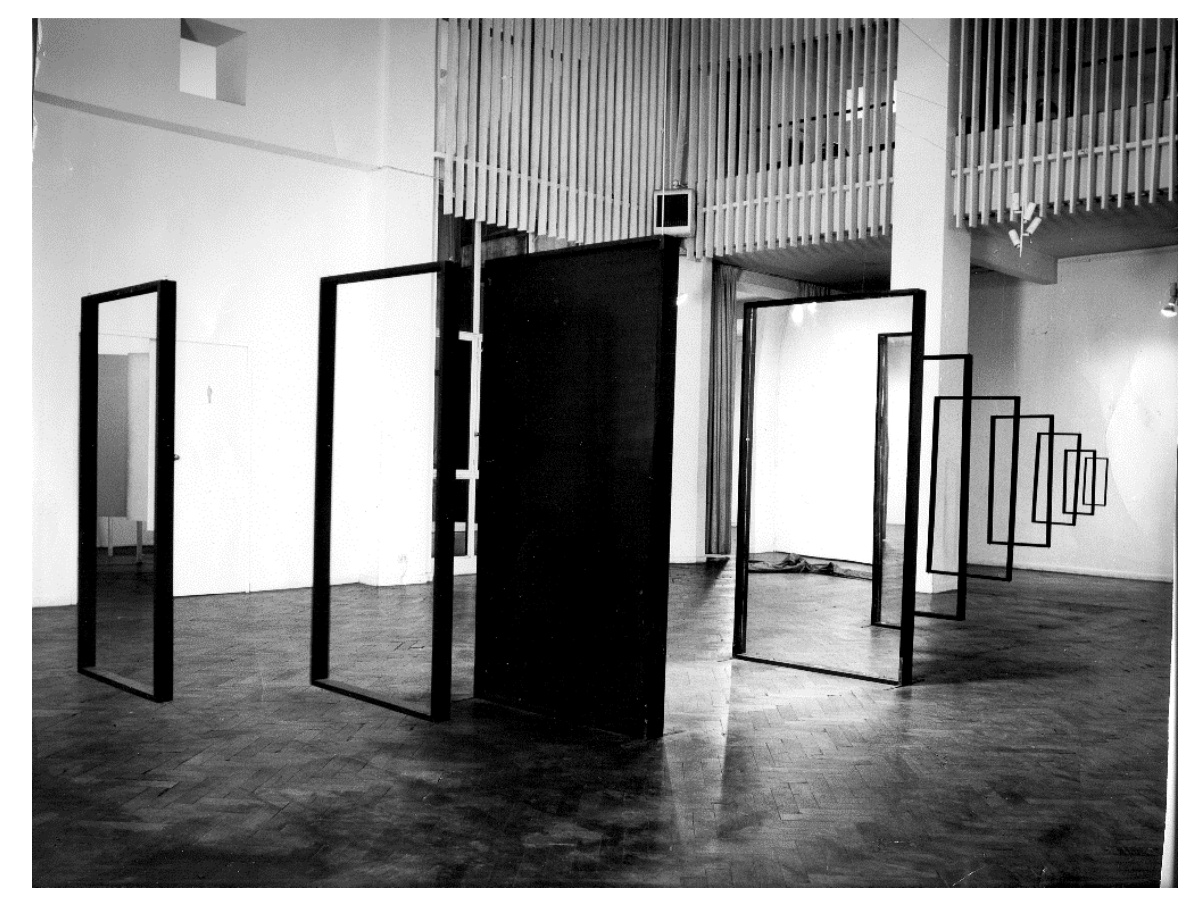

Figura 23 - Verificación esquemática, Antonio Trotta Aço inoxidável e espelho, 1968 Arquivo Instituto Torcuato Di Tella

A obra que chamou mais atenção foi a de Roberto Plate, que acabou gerando o fechamento da exposição e posteriormente o abaixo-assinado dos artistas e a retirada de todos os trabalhos. Contudo, vale ressaltar que a intenção inicial de Plate não tinha qualquer vínculo político, crítica anti-institucional (como foram os casos de Suárez e Jacoby) ou denúncia contra a ditadura. Conhecida, após a polêmica, como El baño, tratava-se de um ambiente que simulava um banheiro com duas portas sinalizadas com placas de feminino e masculino. De acordo com autor, buscava-se que o visitante percebesse que aquele espaço podia produzir em 
sua intimidade "actos de descarga a nível emocional" $"$, imitando uma situação real a ponto de confundi-la. Contudo, o artista não esperava a repercussão que sua obra fosse causar. Sem que estivesse explicitado na proposta, espontaneamente, o público fez diversas intervenções nas paredes, como se fosse um banheiro público. No entanto, algumas daquelas mensagens criticavam o regime de Onganía. A obra foi denunciada e, sob o argumento de que havia inscrições ofensivas às autoridades, a mostra foi fechada. O diretor do Di Tella, Enrique Oteiza, argumentou que a polícia não podia clausurar toda a exposição por causa de uma proposta e ainda buscou apontar a impossibilidade de vigiar a reação dos visitantes dentro do El baño, da mesma forma que era impraticável controlar o modo como as pessoas usam um banheiro público. Os policiais resolveram fechar apenas o trabalho de Plate. Com faixas judiciais, as portas do sanitário ganharam a presença de policiais que vigiavam a obra.

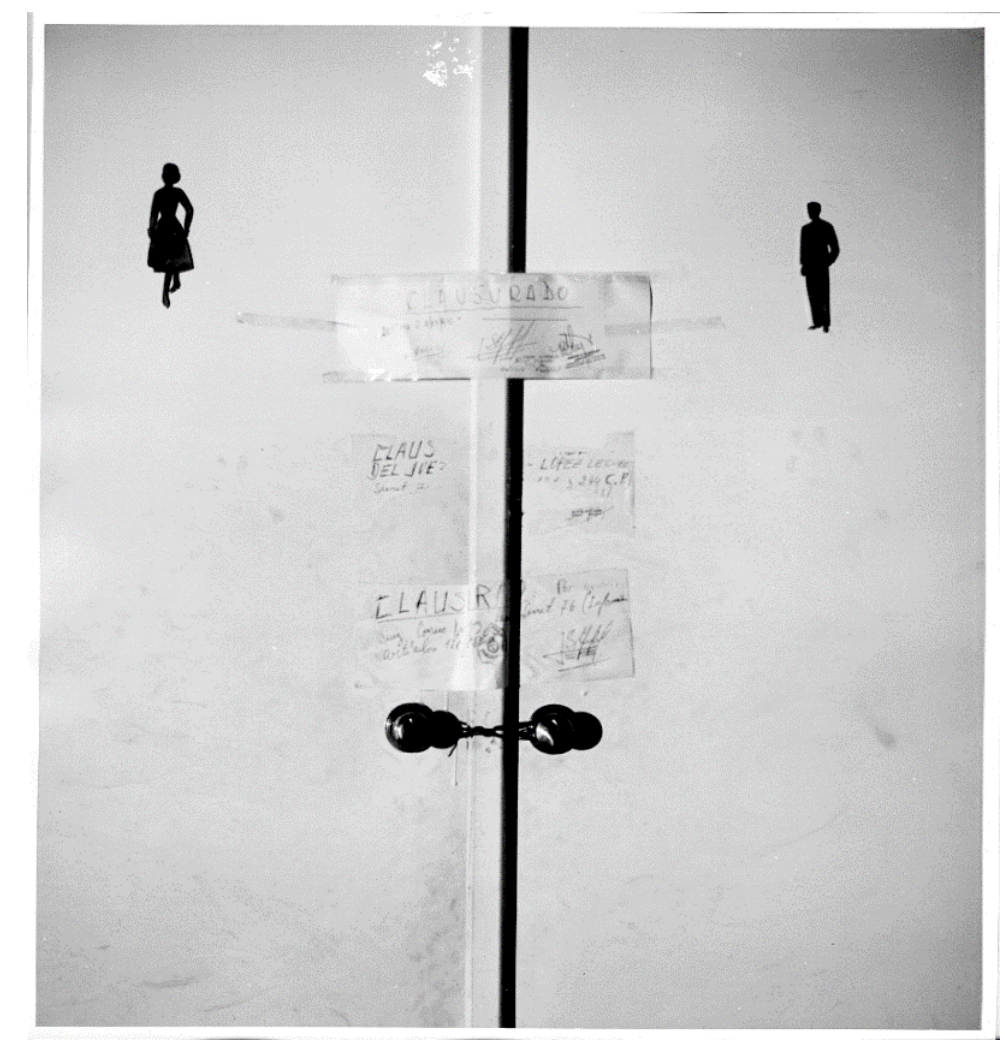

Figura 24 - El baño, Roberto Plate

Dimensões variáveis

Obra censurada com faixas judiciais, 1968

Arquivo Instituto Torcuato Di Tella

\footnotetext{
90 "Atos de descarga a nível emocional." (tradução nossa). Proposta da obra de Roberto Plate. Arquivo Instituto Torcuato Di Tella.
} 
Durante todo esse dia, o público visitou a mostra transformada pela nova "experiência" marcada pela existência dos agentes que se tornaram parte integrante da obra, evidenciando um gesto explícito de censura artística.

Esse fato foi um estopim e acabou por revelar o descontentamento e desconfiança de diversos artistas e intelectuais em relação à imagem do Di Tella como centralizador cultural e como ponto de encontro de uma burguesia alienada aos problemas sociais. Essa representação negativa do Instituto foi crescendo à medida que o regime ditatorial se tornava mais autoritário, sofrendo ataques tanto da direita, que não assimilava as linguagens modernas das vanguardas, e da esquerda, que enxergava o lugar como frívolo e descompromissado com a realidade do país. A ruptura deflagrada pela exposição foi significativa. Em termos plásticos, extrapolavam os gêneros tradicionais e respectivamente não se encaixavam nas terminologias mais recentes da época, como happenings ou objetos. A maior parte das obras apresentadas demonstrava com maior nitidez as consequências extremas da contínua experimentação iniciada anos antes, o conflito crescente com aquele circuito artístico, os dilemas e tensões desencadeadas pela radicalização política dos artistas (LONGONI; MESTMAN, 2008, p. 117). Uma matéria divulgada pelo semanário Primera Plana descreveu de forma clara o percurso das vanguardas e os sinais de colapso suscitados pela exposição:

Una vez agotada la frivolidad de los objetistas, asfixiada de intelectualismo la aventura de las estruturas primarias, la vanguardia estaba justamente condenada a volver a la figuración para sobrevivir; habiendo pasado del plano al volumen, de allí al espacio, y hasta a la temporalidad que proponían las investigaciones cinéticas, esse regreso se parecía a un callejón sin salida... No podía resolverse sino a través de la propuesta que Experiencias 68 significa: un trance agónico; un juego de cartas que abomina de la estética, a riesgo de pasar el resto del tempo a la intempérie, en una tierra de nadie que las artes plásticas no reclamarían, y que ni siquiera el espectáculo - happenings mediante - podría reconocer como suya. ${ }^{91}$

Em solidariedade a Plate, os artistas retiraram todas a obras expostas no Di Tella como forma de protesto aos atos de censura, as levaram para a rua e as destruíram, deixando os

\footnotetext{
91 “Uma vez esgotada a frivolidade dos objetistas, asfixiada de intelectualismo a aventura das estruturas primárias, a vanguarda estava justamente condenada a retornar à figuração para sobreviver; tendo passado do plano ao volume, daí ao espaço, e até mesmo à temporalidade proposta pelas investigações cinéticas, esse regresso parecia um beco sem saída ... Não podia ser resolvido senão através da proposta que Experiências 68 significa: um transe agonizante; um jogo de cartas que abomina a estética, correndo o risco de passar o resto do tempo a intempérie, em uma terra de ninguém que as artes plásticas não alegariam, e nem mesmo o espetáculo dos happenings - poderia reconhecer como seu." (tradução nossa). Primera Plana n. 282. 21 de maio de 1968. Arquivo Instituto Torcuato Di Tella.
} 
restos pela região da Florida. Entretanto, a manifestação terminou com a intervenção policial e a prisão de vários artistas. O diretor do Instituto, Enrique Oteiza, foi posteriormente processado por desacato ao general Onganía e por atentado a moral e aos bons costumes. Os artistas participantes se organizaram e coletaram um abaixo-assinado com a participação de 64 pessoas, entre intelectuais e outros artistas, expondo a fratura causada pelo crescimento da repressão política em diversos âmbitos da sociedade.

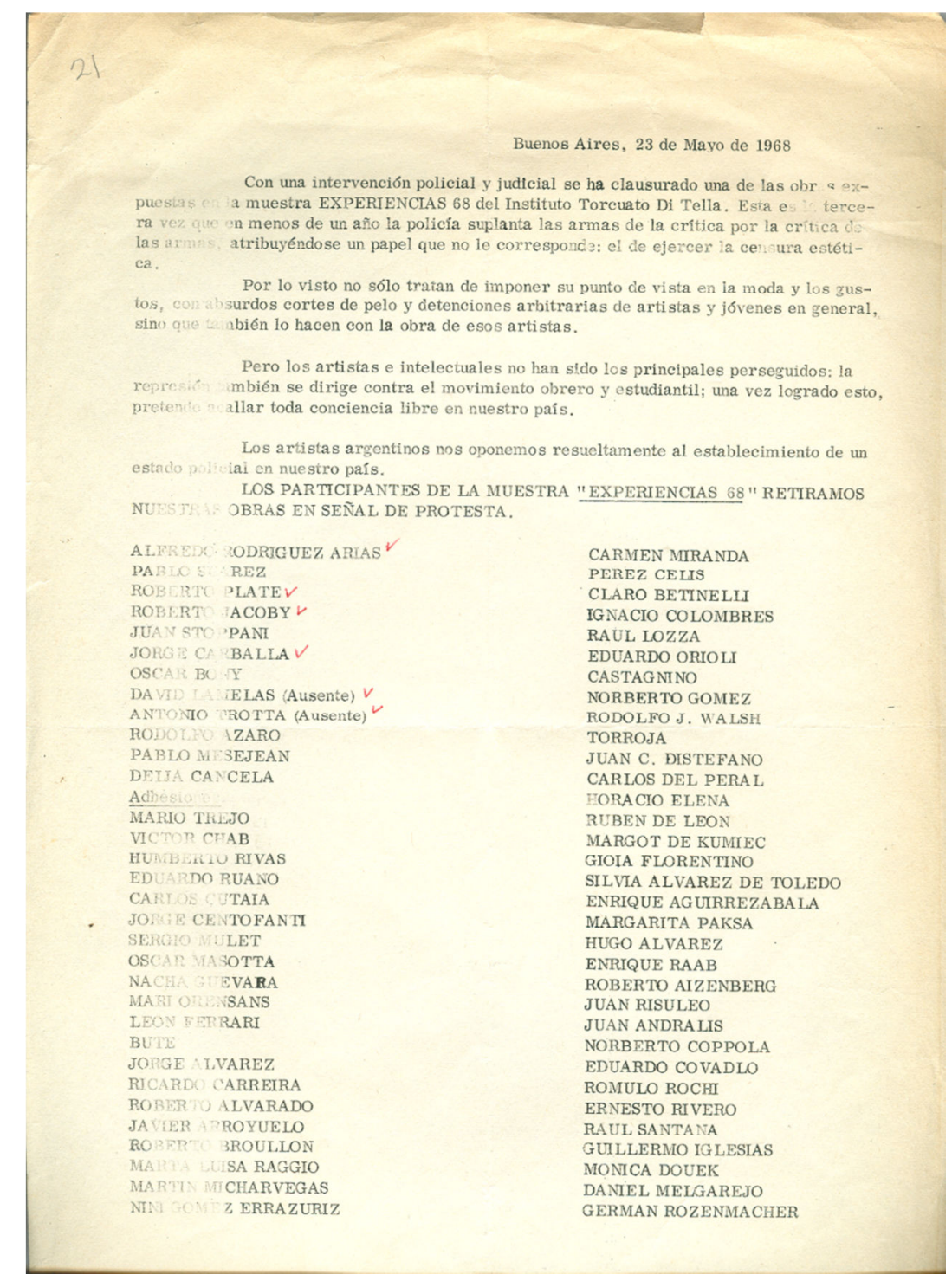

Figura 25 - Abaixo-assinado organizado pelos participantes de Experiencias 68 Arquivo Instituto Torcuato Di Tella

O Centro de Arte do Di Tella era muito visível por sua localização e desde 1966, havia se tornado suspeito para a política cultural do novo regime. O governo atacou diversas áreas da expressão cultural, como teatros e revistas (por razões morais) e ordenou que textos importados, tais como as obras de Marx e Engels, fossem queimados pelas agências do 
correio. Nesse mesmo caminho, o Di Tella era vigiado atentamente por ter se transformado em um centro de cultura juvenil que se expressava por meio da moda (KING, 2007, p.168) e por dar impulso, como sabemos, às vanguardas artísticas. Esse período presenciou a exaltação política tanto da esquerda quanto da direita, e ambos setores se voltaram contra o Instituto, cujo ápice se deu com o fechamento da mostra Experiencias 68.

Outros episódios ${ }^{92}$ reforçaram o distanciamento institucional e deram força à contestação aos prêmios e bolsas, meios de consagração oficiais, que de acordo com Longoni e Mestman, eram o único meio de retribuição econômica dado aos jovens integrantes das vanguardas plásticas. $\mathrm{O}$ circuito artístico tradicional fora cada vez mais rebatido, indicando que a ação política era o caminho mais eficaz e legítimo para as ações artísticas. Foi o caso do Asalto a conferencia de Romero Brest, organizado por artistas da vanguarda de Rosário. $\mathrm{O}$ crítico fora interrompido enquanto dava uma conferência na sala Amigos da Arte da cidade de Rosário. O “assalto" promovido pelos artistas constituía-se por tomar a sala, cortar as luzes do local e ler um manifesto contra a centralização cultural encabeçada pelo Di Tella e a favor dos movimentos sociais. "Creemos que el arte significa un compromiso activo con la realidade [...] Aspiramos a transformar cada pedazo de la realidade en un objeto artístico [...] Mueran todas las instituciones, viva el arte de la Revolución". ${ }^{93}$ No dia seguinte à ação, os artistas visitaram Romero Brest e devolveram o patrocínio que o Di Tella havia dado para promover o Ciclo de Arte Experimental em Rosário e Córdoba.

\footnotetext{
${ }^{92}$ No mesmo ano, Eduardo Ruano apresentou no Prêmio Ver y Estimar um retrato do presidente Kennedy. Na abertura da mostra, o artista apedrejou a sua própria obra sob o grito de ${ }_{i}$ Fuera yanquis de Vietnam!. Na ocasião da abertura da mostra Prêmio Braque, organizada pela Embaixada da França, Margarita Paksa e outros artistas interromperam o discurso do crítico Samuel Oliver, lançando ovos e distribuindo panfletos como forma de protesto pela alteração do edital do concurso, que dava poderes aos jurados para modificar as obras selecionadas, a fim de evitar ações políticas como as de Eduardo Ruano.

93 "Acreditamos que a arte significa um compromisso ativo com a realidade [...] Desejamos transformar cada pedaço da realidade em objeto artístico [...] Morram todas instituições, viva a arte da Revolução." (tradução nossa). In: LONGONI, Ana; MESTMAN, Mariano. Del Di Tella a "Tucumán Arde": vanguardia artística y política en el 68 argentino. Buenos Aires: Editorial Universitaria de Buenos Aires, 2008.
} 


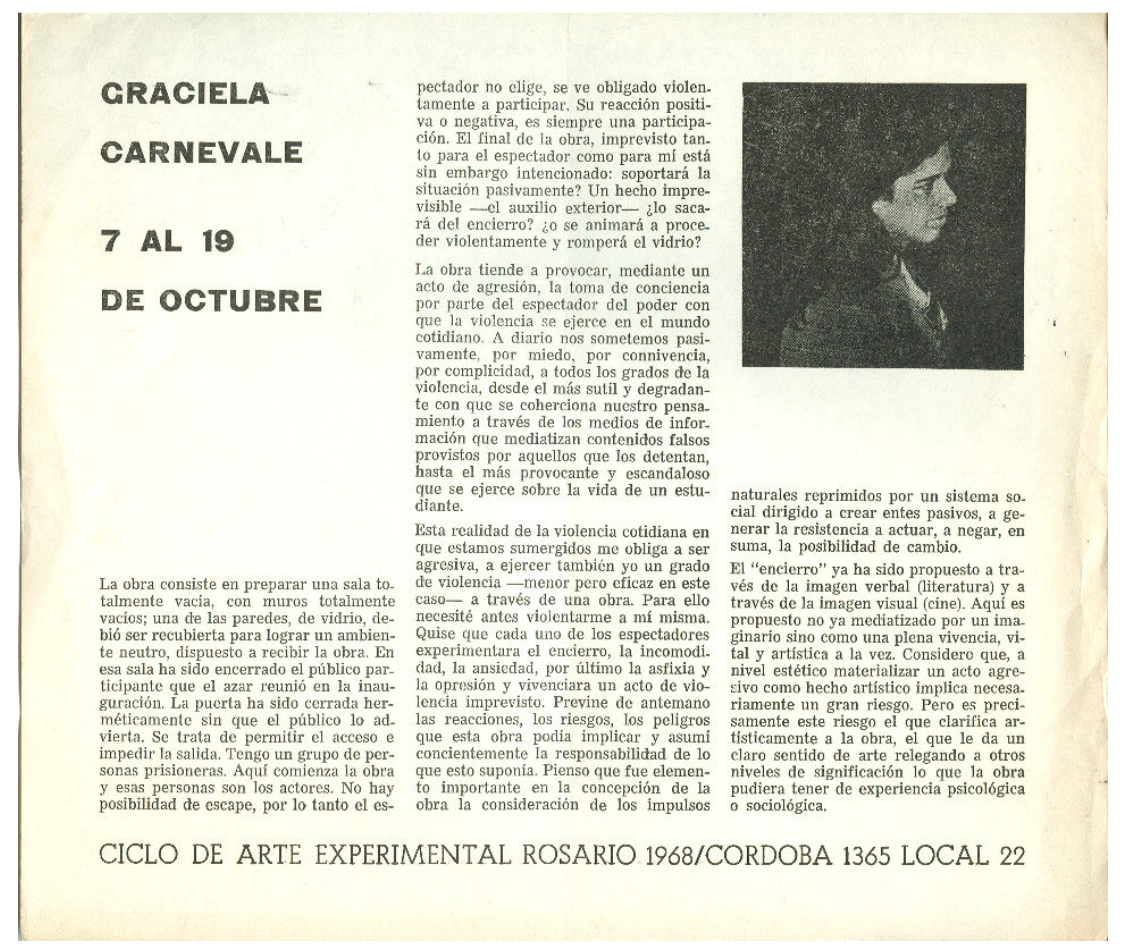

Figura 26 - Folder do ciclo de arte experimental

Arquivo Instituto Torcuato Di Tella

$\mathrm{O}$ elo entre as vanguardas e os movimentos sindicais tornou-se mais estreito e relevante como forma de luta ideológica e cultural. A ação político-artística Tucumán Arde, emblemática para a historiografia da arte contemporânea argentina, formatou-se como uma experiência multidisciplinar com meios de comunicação, que procurava denunciar as condições degradantes as quais estavam sujeitas a população dessa região. O grupo partiu dos anúncios oficiais da mídia corporativa, ligada ao governo militar, conhecida como Operación Tucumán, que na realidade favorecia a indústria açucareira ligada ao capital norte-americano em detrimento dos produtores locais. A Operação fechou parte das refinarias, principal fonte de renda da região, aumentando as taxas de desemprego e pobreza. Os artistas criaram um canal de contrainformação para desmascarar a realidade maquinada pela mídia, demonstrando a inviabilidade desse projeto de modernização ligado às grandes corporações. Intelectuais e $\operatorname{artistas}^{94}$ de Buenos Aires, Santa Fé e Rosário se reuniram durante meses para efetivar essa campanha de comunicação coletiva que funcionou em diversas etapas. Os artistas espalharam

\footnotetext{
${ }^{94}$ Os artistas participantes foram: María Elvira de Arechavala, Beatriz Balvé, Graciela Borthwick, Aldo Bortolotti, Graciela Carnevale, Jorge Cohen, Rodolfo Elizalde, Noemí Escandell, Eduardo Favario, León Ferrari, Emilio Ghilioni, Edmundo Giura, María Teresa Gramuglio, Martha Greiner, Roberto Jacoby, José María Lavarello, Sara López Dupuy, Rubén Naranjo, David de Nully Braun, Raúl Pérez Cantón, Oscar Pidustwa, Estella Pomerantz, Norberto Púzzolo, Juan Pablo Renzi, Jaime Rippa, Nicolás Rosa, Carlos Schork, Nora de Schork, Domingo J.A. Sapia, Roberto Zara.
} 
pela cidade a legenda Tucumán Arde, divulgaram cartazes com o nome fictício do evento, I Bienal de arte de vanguardia, para despistar os agentes de censura, e produziram um levantamento estatístico sobre a realidade social da província. A exposição foi inaugurada em novembro de 1968, na sede do sindicato da CGT (Confederación General del Trabajo), da cidade de Rosário. Incluía fotografias, cartazes e vídeos que denunciavam a grave situação econômica e social da província, em contraposição aos índices divulgados pelos meios de comunicação oficial, blindados pela ditadura de Onganía. Essa ação representava "a operacionalização da mídia pelos artistas ao revelar, por meio da exposição, a não contradição entre o controle de informação, arte e política” (FREIRE, 2006, p 31).

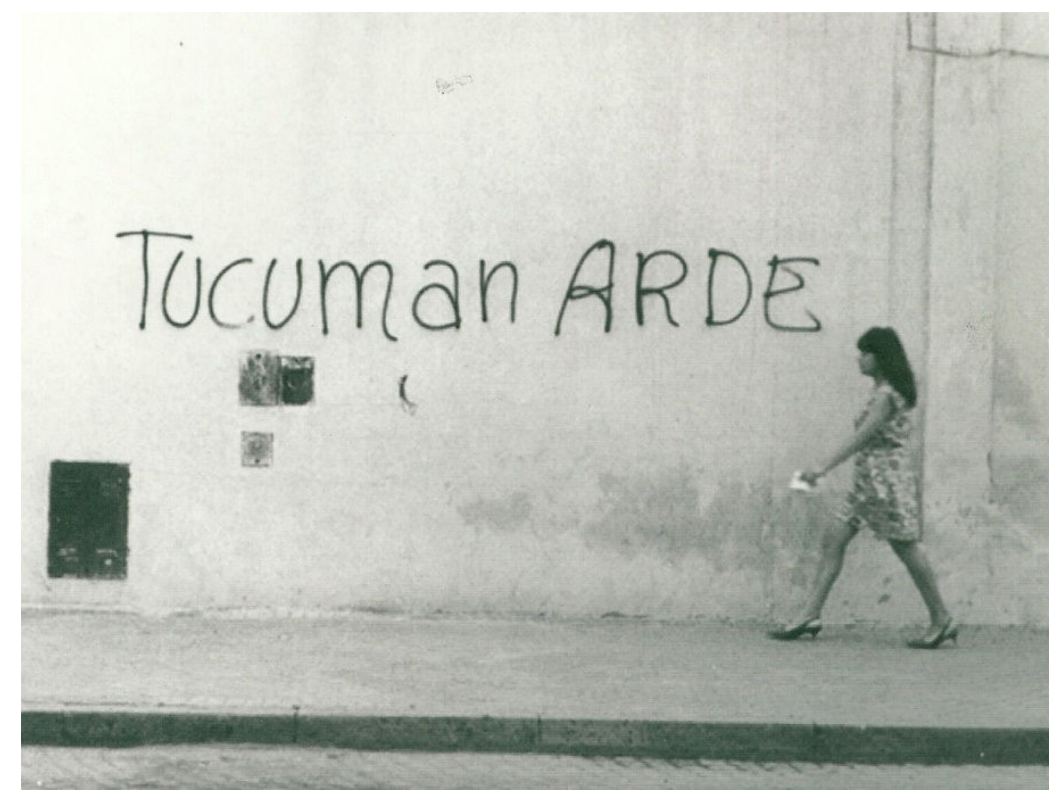

Figura 27 - Tucumán Arde, 1968

O artista León Ferrari escrevera sobre Tucumán Arde pontuando que "su propósito era hacer del arte una herramienta revolucionaria, usar el arte para hacer política, participar con su profesión en el processo de liberación de nuestro país". ${ }^{95}$ E concluiu que a ação teve um forte impacto sobre a vanguarda ligada ao Di Tella, acarretando no seu colapso final. A atitude anti-institucional tornou-se cada vez mais urgente uma vez que os artistas perceberam

\footnotetext{
95 “Seu propósito era fazer da arte uma ferramenta revolucionária, usar a arte para fazer política, participar com sua profissão no processo de liberação do nosso país." (tradução nossa). Resposta a um questionário da Escola de Letras da Universidade de Havana, 1973. In: LONGONI, Ana; MESTMAN, Mariano. Del Di Tella a "Tucumán Arde": vanguardia artística y política en el 68 argentino. Buenos Aires: Editorial Universitaria de Buenos Aires, 2008.
} 
que quaisquer obras, por mais radicais e subversivas que fossem, perdiam sua potência crítica ao serem expostas dentro do circuito tradicional. Essas exigências demandavam outras referências institucionais, a formação de um novo público, a produção de novos meios de circulação e recepção. No caso do Di Tella, os artistas que assumiram essa postura antiinstitucional buscavam questionar a procedência das fontes econômicas do Instituto, parte subsidiada por empresas como Ford e Fundação Rockfeller. A imagem negativa do Di Tella foi reforçada no filme La hora de los hornos (1967), do cineasta Fernando Solanas. De acordo com a película, o Instituto fazia parte de "un ataque neocolonial contra los valores nacionales argentinos" (KING, 2007, p. 47) e exercia uma forma de violência cultural ao copiar passivamente modelos estrangeiros sem se preocupar com os problemas e demandas locais.

Marta Traba também havia alertado sobre os "perigos da mimetização e da vergonha da entrega" (1977, p. 96) no período denominado pela crítica de "duas décadas vulneráveis" da arte latino-americana. No prefácio do livro, Traba escreve:

\footnotetext{
Quatro séculos de dominações culturais sucessivas explicam - embora não justifiquem - a passividade com que, no começo do século XX, esta arte copia largamente os modelos que a Europa fornece e, ao definir-se a supremacia de Nova Iorque na estética atual, abre caminho à estética da deterioração sem apresentar resistência. Para saber qual é o grau de sua obediência e poder estabelecer por que razões tal submissão é uma falha grave da arte continental, importa determinar, antes de mais nada, que elementos os Estados Unidos nos transmitem ao longo de 20 anos que constituem o tema do ensaio: 1950 a 1970 (TRABA, 1977).
}

O "esnobismo argentino" (TRABA, 1977, p.125) na criação artística e a “decomposição das vanguardas” (1977, p. 83) provocada pelo colapso do Di Tella eram sintomas do que Traba chamava de estética da deterioração. Quer dizer, estéticas importadas de culturas urbanas e sociedades de consumo altamente industrializadas e reajustadas às condições locais, recordando com a crítica que na maior parte das cidades da América Latina, a vida urbana ainda era uma terminologia remota e "sem sentido" (1977, p.17).

O fechamento do CAV deveu-se a uma série de fatores relacionados a pressões políticas, à crise financeira da instituição e à resistência de vários artistas. O Instituto Di Tella, como vimos, foi fundado em uma época de livre circulação de fundos internacionais e, ao longo da década de 1960, o fluxo da contribuição norte-americana foi diminuindo gradativamente, assim como a verba advinda das Companhias Di Tella. O foco internacionalista de Romero Brest tornou-se extremamente custoso e a partir de 1968, o 
diretor precisou readaptar o programa de exposições, substituindo os Prêmios Internacionais pela continuidade da proposta nacional das Experiencias Visuales. Os artistas que protagonizaram as principais mostras do Di Tella se afastaram da instituição por diferentes razões - o grupo da pop art expandiu a produção para outros centros metropolitanos, como Paris e Nova Iorque, enquanto os artistas mais politizados haviam adotado uma tática antiinstitucional trabalhando em áreas populares, como foi o caso de Tucumán Arde (KING, 2007, p. 290). Chegando ao fim do percurso dessa década, um grupo de artistas se afastou definitivamente do circuito artístico e migrou para outras áreas, uma delas a militância política; outros avançaram no campo da experimentação de outras linguagens como o teatro, moda e design.

Romero Brest apresentou alguns projetos para reestruturar o CAV devido aos problemas de ordem econômica e à urgência de novas demandas artísticas. A interdisciplinaridade e o uso de diversas ferramentas como slides, filmes, gravadores e outros meios tecnológicos buscavam ampliar e estimular o fenômeno da interação de linguagens.

Sin embargo, creo que si bien el caminho de la interacción es viable y conveniente, está lejos de resolver el problema, como lo revelan quienes practican el "arte conceptual". En consecuencia, creo que los papeles están cambiando [...] Y más activos aún los medios masivos de comunicación: la televisión, la radio, el periodismo, los posters etc: los cuales inciden muy desgadamente en la labor de los artistas visuales (BREST, 1992, p. 206)

O crítico percebeu a mudança no papel dos artistas e propôs um laboratório de experimentação com máquinas modernas em paralelo ao imperativo de aprofundar as teorias relacionadas à comunicação, percepção e sociologia, procurando transformar o CAV em um centro de investigação teórica. Com a verba menor e sob a pressão de coordenar um programa reduzido, Romero Brest acabou renunciando ao cargo em 1970.

É fundamental ressaltar que o projeto-piloto de Brest para a criação de um laboratório interdisciplinar que visava estimular as práticas artísticas voltadas aos meios de comunicação e o interesse pelas novas tecnologias, foi uma das premissas do CAYC - Centro de Arte y Comunicación, ainda em 1968, e que marcaria o circuito portenho de arte na década posterior.

\footnotetext{
96 "No entanto, creio que se o caminho da interação é viável e conveniente, está longe de resolver o problema, como revela os que praticam a "arte conceitual". Em consequência, creio que os papéis estão se transformando [...] E os mais ativos ainda são os meios de comunicação: a televisão, o rádio, o jornalismo, os posters etc.: que são os meios que incidem no trabalho dos artistas." (tradução nossa).
} 
Desde os seus primeiros anos, o CAYC seguiu uma vocação interdisciplinar de integração cultural baseada na articulação de três eixos principais: a arte, a arquitetura e a comunicação.

Veremos a seguir que ao longo da década de 1970, o CAYC teve profunda influência no cenário artístico argentino e latino-americano, substituindo as políticas internacionalistas promovidas por Romero Brest nos anos anteriores. Por meio de quais estratégias Glusberg deu continuidade ao fomento internacionalista e quais foram as principais diferenças entre os projetos institucionais do Di Tella e do CAYC? Quais linguagens artísticas foram priorizadas para internacionalizar a arte argentina nesse período? Como Glusberg criou um aparato teórico e institucional para agenciar essas linguagens? Com a radicalização política deflagrada pela mostra Experiencias 68, quais foram as táticas do CAYC para inserir as demandas sociais no marco de sua instituição? 


\section{CAPítulo 2}

\section{CENTRO DE ARTE Y COMUNICACIÓN - CAYC}

O Centro de Arte y Comunicación, fundado em 1968, foi uma instituição privada dirigida pelo empresário e crítico de arte Jorge Glusberg que funcionou durante 26 anos. De caráter interdisciplinar, buscava reunir artistas, arquitetos, cientistas sociais, especialistas em comunicação e demais áreas culturais, resultando na confluência de diferentes campos do conhecimento. A base de articulação partia do cruzamento de três eixos essenciais: arte, comunicação e arquitetura. O folder "Qué es el CAyC" informava que a finalidade básica do Centro era a "integración de las diversas disciplinas, integración de la teoria y la práctica del arte y la arquitectura, e integración espacial [...] através del intercambio de personas y la circulación de obras e información, tanto en plano nacional como internacional". ${ }^{97}$

O Centro era composto por três departamentos específicos: Artes; Arquitetura; Comunicação e Desenho. Desde 1969, promoveu uma série de palestras, seminários sobre epistemologia, filosofia, linguística, semiologia e arte, visando a integração entre os campos cultural e científico. A missão era estar na ponta de lança das discussões mais relevantes no âmbito internacional e inseri-las no meio argentino. Antes de ganhar uma sede fixa, em 1970, o CAYC organizou colóquios e exposições em galerias e centros culturais de Buenos Aires. A primeira exposição na sede fixa, na rua Viamonte, já evidenciava as ambições internacionalistas da instituição, com a inauguração da mostra Nueva Fotografía: USA, organizada pelo MoMA. O CAYC foi o principal representante argentino das tendências de caráter conceitual durante a década de 1970. Algumas das estratégias de consolidação institucional e mobilidade no circuito internacional se basearam em uma ampla divulgação das atividades do Centro, por meio das conhecidas gacetillas amarillas; da elaboração de uma categoria (Arte de Sistemas) que abarcasse a produção conceitual amparada por Glusberg; e da formação de um grupo de artistas (Grupo de los Trece).

O CAYC substituiu o protagonismo antes encabeçado pelo Instituto Di Tella e preencheu o vácuo cultural da cidade portenha, depois do fechamento dessa instituição. As

\footnotetext{
97 "integração das diversas disciplinas, integração da teoria e da prática da arte e da arquitetura e integração espacial [...] através do intercâmbio de pessoas e a circulação de obras e informação, tanto no plano nacional quanto internacional." (tradução nossa). Folder CAyC (08407). Pasta CAyC - Biblioteca Lourival Gomes Machado.
} 
propostas apoiadas por Romero Brest, que abarcavam experiências com os meios de comunicação, mais especificamente a televisão, continuaram cruciais para o desenvolvimento das últimas tendências artísticas da época. Artistas e intelectuais criaram um extenso repertório reflexivo sobre o impacto dos meios de comunicação e das novas tecnologias sobre a arte e a sociedade. Gradativamente, os recentes meios tecnológicos tornaram-se acessíveis e abriram um campo de investigações artísticas com o uso de novas ferramentas - dispositivos mecânicos, luzes, máquinas, projeções fotográficas e de cinema, vídeo e computadores.

A aproximação entre ciência e artes visuais e o interesse em explorar as novas tecnologias marcaram a produção de muitas vertentes da arte argentina, desde a década de 1940. As referências à ciência encontraram seu correlato em experiências formais que privilegiavam as bases matemáticas e estruturas geométricas. Houve um empenho em buscar uma arte de "ordenación dinâmica móvil independiente de expresión y representación favoreció la producción de obras con movimiento" (ALONSO, 2005) ${ }^{98}$. As experiências do artista concreto Gyula Kosice, em 1946, com esculturas de néon e tubos fluorescentes ${ }^{99}$, produziram um fértil diálogo entre arte e tecnologia. Duas décadas mais tarde, a penetração da televisão na produção artística e os diversos experimentos com o novo meio redefiniram a relação do público com a imagem em movimento. Sabemos da relevância da investigação da televisão em obras de Marta Minujín, como Simultaneidad en simultaneidad, de 1966, e Situación de tempo, de David Lamelas, no contexto da mostra Experiencias Visuales 1967, ambas no Di Tella ${ }^{100}$.

\footnotetext{
98 "ordenação dinâmica móvel independente de expressão e representação favoreceu a produção de obras com movimento." (tradução nossa). ALONSO, Rodrigo. Arte y tecnologia en la Argentina: Los primeros años. www.roalonso.net. Acesso em 01 jun. 2015.

${ }_{99}$ É válido ressaltar que o artista norte-americano Dan Flavin iniciaria sua pesquisa minimalista com tubos fluorescentes quase duas décadas depois.

${ }^{100}$ Para realizar essa obra, Minujín convidou 66 participantes que foram filmados, fotografados e entrevistados antes de ocuparem um lugar diante da televisão, a qual deveriam assistir ao mesmo tempo em que escutavam uma estação de rádio. Alguns dias depois, fotografias e filmes com a imagem dos participantes, executadas no primeiro dia, foram projetadas nas paredes. Eles sentaram nos mesmos lugares e observaram suas entrevistas e imagens nos televisores. ALONSO, Rodrigo. Arte y tecnologia en la Argentina: Los primeros años. www.roalonso.net. Acesso em 01 jun. 2015.

Situación de Tiempo, de David Lamelas, apresentava uma sala iluminada por 17 televisores que transmitiam um sinal com ruídos e sons, evidenciando a temporalidade dos meios eletrônicos.
} 


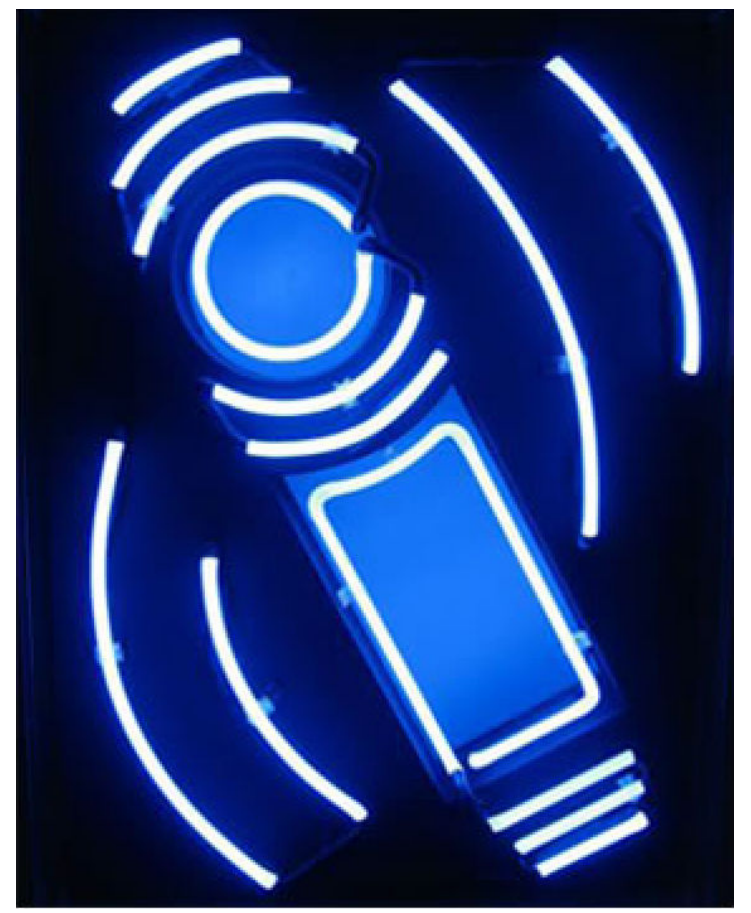

Figura 28 - Sobre relieve, Gyula Kosice Gás neon, 65 x 37,5 x $17 \mathrm{~cm}, 1950$

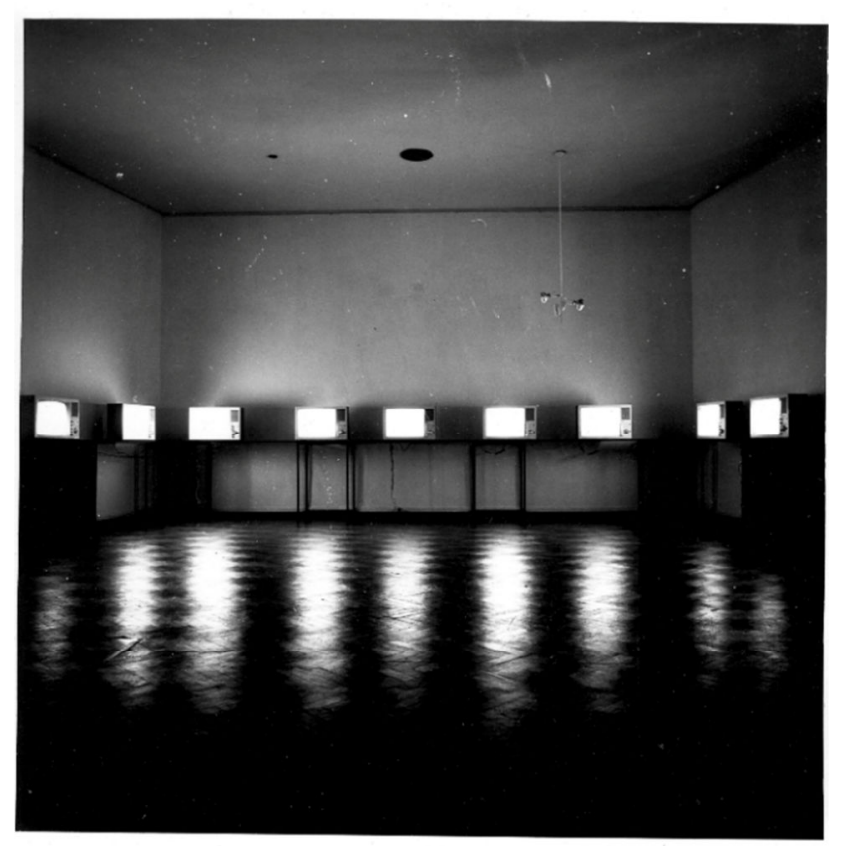

Figura 29 - Situación de tiempo, David Lamelas, Instalação com 17 televisores, 1967 Arquivo Instituto Torcuato Di Tella 
O impacto das teorias da comunicação e o uso das novas tecnologias no processo criativo impulsionaram as primeiras exposições organizadas pelo CAYC. A parceria entre artistas e engenheiros havia caracterizado algumas mostras internacionais importantes, como a Cibernetic Serendipity, de 1968, em Londres, e as pesquisas realizadas pelo Grupo EAT (Experiments in Art and Technology), de Nova Iorque, dirigido pelo pintor Robert Rauschemberg e o engenheiro Billy Kluver. A estratégia de estar em consonância com as principais discussões e exposições que circulavam no circuito artístico dos EUA e da Europa serviram de estímulo para a realização da mostra Arte y Cibernética (1969), na Galeria Bonino. Integrada por artistas japoneses, ingleses e argentinos, e organizada pelo CAYC, foi a primeira mostra do gênero na América Latina.

Foram usadas as memórias de um computador IBM e uma máquina de desenho automático, propriedades da escola técnica ORT. Os artistas convidados foram auxiliados por analistas e engenheiros com o intuito de dar conta das possibilidades abertas por esses aparatos tecnológicos, gerando uma criação conjunta de novas linguagens. $\mathrm{O}$ eclético grupo de artistas argentinos - Luis Benedit, Antonio Berni, Rogelio Polesello, Ernesto Deira, entre outros, foi convidado para a experimentação de desenhos mediados por esses softwares. Havia, nesse momento, a crença de que o desenvolvimento dos estudos cibernéticos afetaria profundamente o processo cognitivo e que os computadores proporcionariam uma transformação tão intensa como fora o processo de substituição do trabalho manual pela produção de máquinas industriais. Em sintonia com essas ideias, Glusberg escreveu no catálogo expositivo:

“ [...] el desarrollo de ciertos modelos cibernéticos ha permitido construir sistemas artificiales que hasta hace menos de diez años eran característicos y exclusivos de la actividad humana. [...] El desinterés cada vez mayor en la obra de arte como objeto, obligó a los artistas a buscar nuevos canales de Comunicación; la nueva tecnologia y los nuevos medios están evolucionando hacia una nueva situación cultural". ${ }^{101}$

\footnotetext{
101 “[...] o desenvolvimento de certos modelos cibernéticos tem permitido construir sistemas artificiais que até menos de dez anos atrás eram característicos e exclusivos da atividade humana. [...] O desinteresse cada vez maior na obra de arte como objeto obrigou outros artistas a buscarem novos canais de Comunicação; a nova tecnologia e os novos meios estão evoluindo para uma nova situação cultural.” (tradução nossa). GLUSBERG, Jorge. Arte y Cibernética (cat.exp.), Buenos Aires, 1969. (09022) Pasta CAYC - Biblioteca Lourival Gomes Machado
} 


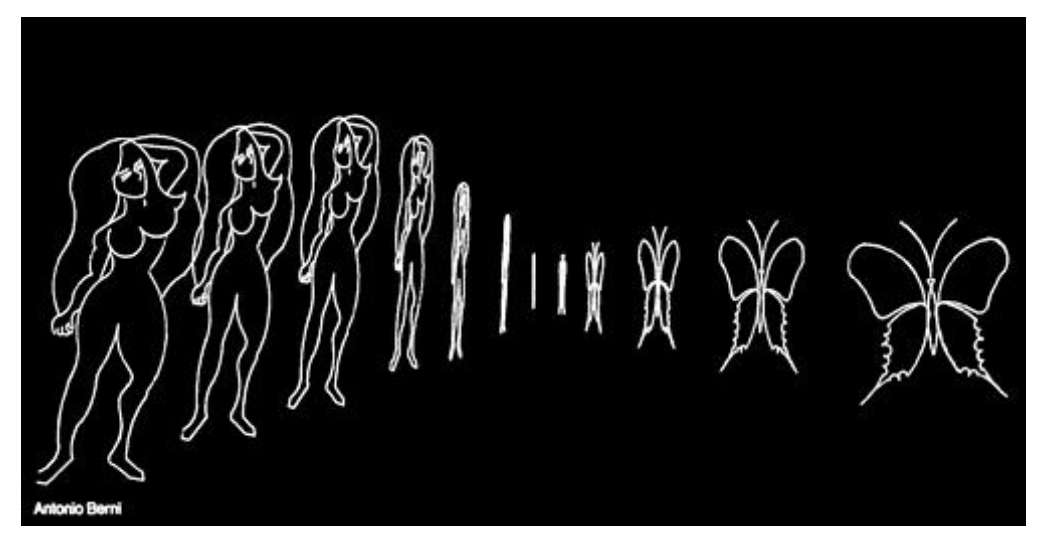

Figura 30 - Sem título, Antonio Berni, 1969

Diferentemente das investigações estrangeiras, focadas no maquinário científico, o eixo de interesse do CAYC buscou evidenciar os sistemas de comunicação. Apenas pela natureza comunicacional dos dispositivos tecnológicos se estabeleceria o comprometimento entre a arte e o seu contexto social. A preocupação do artista, de acordo com Glusberg, deveria ressaltar o processo (os sistemas de comunicação) de constituição da obra e não mais o objeto de arte em si. Observamos nesse ponto de partida reflexivo, ainda circunscrito à relação entre ciência, arte e o meio social, parte do dispositivo teórico que será posteriormente desenvolvido para pensar o marco das produções de caráter conceitualista do CAYC. Desde os primórdios do Centro, Glusberg demonstrou grande empenho em se conectar com uma ampla rede de críticos, teóricos e artistas estrangeiros. Importava conceitos, práticas e as adaptava ao contexto regional, como foi o caso da releitura local da relação entre arte e tecnologia, pela via dos canais de comunicação.

A divulgação e incorporação de correntes culturais externas era complementar a ofensiva publicidade e projeção da produção local no exterior. A relação dialética entre regionalismo e internacionalismo marcou gradativamente o processo de formação e consolidação do CAYC, demonstrando essa via de mão dupla de trocas artísticas. Ao mesmo tempo em que Glusberg trazia inúmeras mostras e críticos estrangeiros a Buenos Aires, negociava a circulação de diversas exposições e artistas argentinos ligados à sua instituição no circuito internacional. O crítico afirmava que "las expresiones culturales reflejan los problemas específicos del contexto que inspiró su realización" (GLUSBERG, 1985, p. 96) ${ }^{102}$, e desde essa perspectiva, o CAYC privilegiou o intercâmbio cultural com alguns países latino-americanos, mediante a promoção de exibições individuais e coletivas de arte

\footnotetext{
102 "as expressões culturais refletem os problemas específicos do contexto que inspirou a sua realização." (tradução nossa).
} 
argentina. Desde Arte y Cibernética, nota-se o esforço de Glusberg em traçar uma síntese da história da arte buscando inserir a produção de Buenos Aires, ligada ao CAYC, nesse circuito. Além da ambição de projetar a arte local a nível internacional, o crítico apresentava a arte argentina em pé de igualdade com o que era produzido fora.

Em 1970, Glusberg, uma equipe de cientistas e o artista Luis Fernando Benedit representaram o país na XXXV Bienal de Veneza, com a obra Biotrón. Tratava-se de um habitat artificial com flores mecânicas que produziam néctar e alimentavam abelhas, mediante o controle eletrônico. A tecnologia encarregada de estudar o controle dos sistemas de comunicação, das máquinas e, neste caso, de seres vivos, foi a problemática trabalhada pelo artista que, além de apontar a contradição entre o natural e o artificial, elaborou uma grande metáfora das relações entre ciência e arte. A obra simulava uma série de experimentos científicos com animais, apresentando um mecanismo composto por 25 flores e 4.000 abelhas localizadas em um dispositivo transparente, que permitia o espectador observar esse micro ecossistema.

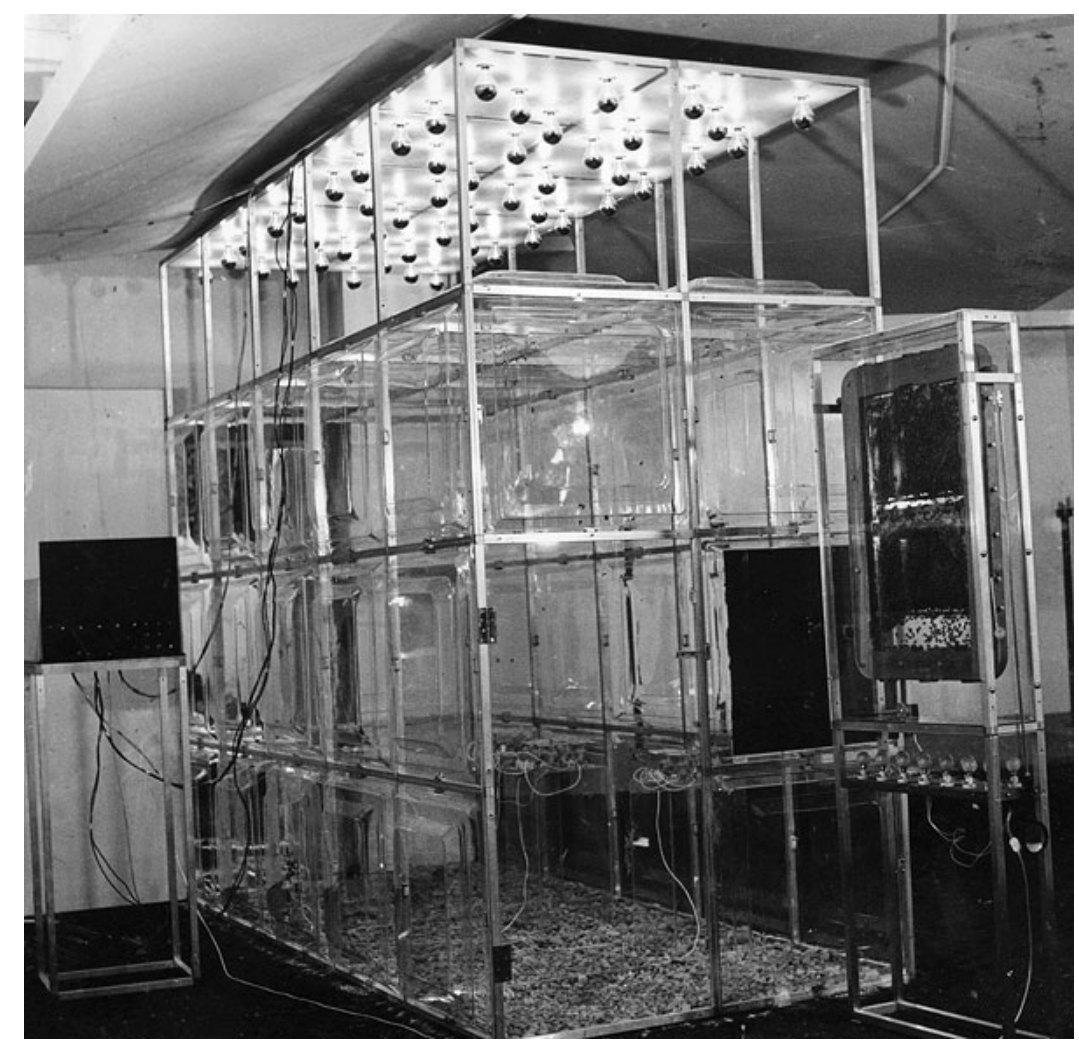

Figura 31 - Biotrón, Luis Fernando Benedit Instalação, 300 x 500 x $200 \mathrm{~cm}, 1970$ 
Outro artista ligado ao CAYC, Victor Grippo, também buscou relacionar a investigação científica à criação artística, por meio da observação dos processos pelos quais a natureza se manifestava. Grippo certa vez escrevera sobre seu trabalho:

No se trata de reproducir los objetos que tan bien produce la naturaleza, sino reproducir los processos por los cuales la naturaleza llega a tales objetos. Tampoco se trata de tomar a la ciencia como arte o, al revés, en una inversión mecânica. Mejor es pensar que la ciencia contiene belleza, que una mirada atenta puede descobrir la belleza de una ley y aun la belleza de un experimento. Y también el arte contiene, a su modo, una ley natural" (GRIPPO apud GLUSBERG, 1985, p. 168) ${ }^{103}$.

O artista desenvolveu uma série de trabalhos com batatas, medindo com um voltímetro a energia que estas produziam. O sistema de analogias criado por Grippo procurava estabelecer uma relação entre a energia movida pelo tubérculo e a consciência do homem latino-americano. A batata não foi escolhida por acaso, pois tratava-se de um alimento originário da região sul-americana e base alimentar das populações pobres do continente, que chegou a transformar profundamente os hábitos dos europeus. Por isso ela foi considerada “uma planta revolucionária” (MORAIS, 1979, p. 56).

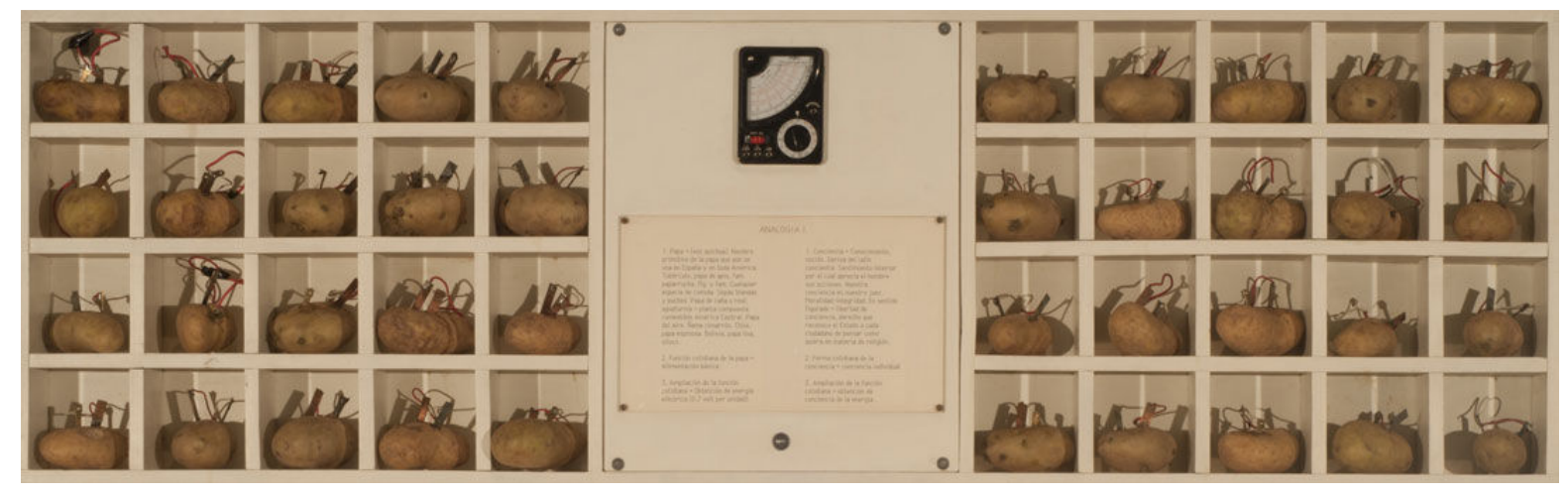

Figura 32 - Analogía I, Victor Grippo Instalação, 47,4 x 153 x $10 \mathrm{~cm}, 1970-1971$

\footnotetext{
103 "Não se trata de reproduzir os objetos que tão bem a natureza produz, mas reproduzir os processos pelos quais a natureza chega a tais objetos. Tampouco se trata de tomar a ciência como arte, ou, ao contrário, em uma inversão mecânica. Melhor é pensar que a ciência contém beleza, que um olhar atento pode descobrir a beleza de uma lei e ainda a beleza de um experimento. E a arte também tem, a seu modo, uma lei natural." (tradução nossa).
} 
A tecnologia experimentada por esses artistas adquiriu um sentido diferente, ingressando não mais como um meio para transformar a vida, mas como paradigma de produção de conhecimento e informação que permitiam analisar a realidade e o meio social. $\mathrm{O}$ artista tornou-se um investigador da realidade, um analista de sistemas e dos processos que a constituem. Por meio do dispositivo tecnológico e científico, foi capaz de dar novas interpretações às construções discursivas e ideológicas (ALONSO, 2005) ${ }^{104}$.

Outra tentativa de o CAYC aproximar a tecnologia do entorno social, com foco nas trocas interdisciplinares, foi por meio de Argentina Inter-Medios, um evento de dois dias organizado na ocasião do X Congresso Mundial de Arquitetos, sediado em Buenos Aires. O objetivo era gerar acontecimentos que marcassem a relação do homem e o espaço social que o cercava, por meio de espetáculos efêmeros que integrassem diferentes disciplinas. $\mathrm{O}$ texto do catálogo ressaltava que

En Argentina Inter-medios el uso de la música electrónica, films experimentales, poesia, proyecciones, danza, esculturas neumáticas y cinéticas, constituye un enviroment total donde los diferentes estímulos, en un intercambio dinâmico, ponen los medios al servicio de la percepción audiovisual (GLUSBERG, 1969). ${ }^{105}$

Glusberg convidou músicos de vanguarda que se juntaram a pintores, bailarinas, escultores, cineastas e atores de teatro experimental com o intento de buscar soluções para aproximar de forma eficaz a arte, a tecnologia e o meio social. Desse modo, de acordo com o texto de apresentação da mostra, esperava-se que o espectador alcançasse aquele instrumental artístico para compreender melhor a realidade tecnológica e urbana que o cercava.

O CAYC continuou a investir nas programações que instigassem as relações entre o artista e o seu entorno, aproximando cada vez mais a arte das demandas políticas e da ideologia. Os embates internos ao campo artístico que protagonizaram as principais discussões da década de 1960, como a querela entre abstracionismo e figurativismo ou a "morte da pintura" pareciam ultrapassadas. A realidade econômica e social do país ancoradas em uma sequência de crises e trocas presidenciais, no crescimento da censura e da iminência de um golpe militar conduziram novas articulações entre o movimento estudantil, sindical e

\footnotetext{
${ }^{104}$ ALONSO, Rodrigo. Arte y tecnologia en la Argentina: Los primeros años. www.roalonso.net. Acesso em 07 jun. 2015.

105 “Em Argentina Inter-medios, o uso da música eletrônica, filmes experimentais, poesia, projeções, dança, esculturas neumáticas e cinéticas, constitui um enviroment total onde os diferentes estímulos, em um intercâmbio dinâmico, põem os meios à serviço da percepção audiovisual." (tradução nossa). GLUSBERG, Jorge. Argentina Inter-medios (cat. exp.), Buenos Aires: CAYC, 1969.
} 
os grupos armados. A Argentina assistiu ao Cordobazo, importante levantamento popular que impulsionou outras mobilizações coletivas.

Glusberg, sempre atento às demandas da época, organizou a primeira mostra ao ar livre de Buenos Aires, chamada Escultura, Follaje y Ruidos, em 1970, na praça Rubén Darío. Buscando aproximar a produção artística da vivência da rua, convidou diversos artistas, entre eles, Edgardo Antonio Vigo, Carlos Ginzburg, Luis Benendit e Vicente Marotta. O folder informativo sobre o evento explicava que essa exposição ocuparia a rua para dialogar com o público, em um intercâmbio de mútua aproximação. As obras sairiam do âmbito dos museus e galerias para dividirem o espaço com os transeuntes. É provável que o crítico tenha se inspirado na ação Tucumán Arde, realizada dois anos antes, para organizar Escultura, Follaje y Ruidos. Os artistas envolvidos na mostra do CAYC não tinham, necessariamente, vínculo com os sindicatos nem participavam ativamente da militância política, contudo, a proposta de ocupar a rua problematizava a relação do homem com o seu contexto social. Em 1969, Glusberg escrevera um artigo sobre a ação organizada pela vanguarda de Rosário: "para este grupo es más importante una muestra de arte en una fábrica o en la calle, que en el recinto cerrado de una galeria. Lo que hacen en definitiva es repudiar las mustras estereotipadas". 106 Seguindo essa lógica, a mostra na praça Rubén Darío abdicou do circuito tradicional e das experiências com dispositivos tecnológicos, como os computadores utilizados nos primeiros eventos do CAYC, para instigar a realização de uma arte espontânea que ativasse a participação do espectador.

Vigo e Ginzburg, por exemplo, apresentaram PROYECTO A REALIZAR, um dos diversos "senãlamientos" criados pelo artista platense, sinalizando imagens que estimulassem uma experiência estética dentro do contexto urbano e do objeto sinalizado. A ideia era que qualquer um pudesse pegar um giz, marcar uma cruz no chão e dar um giro de 360 graus na ponta dos pés ou sentado. Qualquer uma dessas possibilidades permitiria um exercício de passeio visual pela praça. Sobre a ação, Vigo escreveu:

Propuesta: UN PASEO VISUAL A LA PLAZA RUBEN DARÍO, Buenos Aires, Centro de Arte y Comunicación (CAyC), 1970. La no existencia de la obra, la no necesidad de estar presente, la efemeridad del estar, la posibilidad "abierta" a concretar disímeles "ACTOS" a los propuestos nos convierte a

\footnotetext{
106 “Para este grupo é mais importante uma mostra de arte em uma fábrica ou na rua do que em um recinto fechado de uma galeria. O que fazem definitivamente é repudiar as exposições estereotipadas." (tradução nossa). GLUSBERG, Jorge. 17 artistas detrás de la dialéctica de lo simple: Tucumán: planta piloto para un nuevo concepto. Artiempo (Buenos Aires), n. 4 (jan-fev. 1969): 12-13. ICCA - Documents of 20th-Century Latin American and Latino Art. Registro: 750378. Acesso em 08 jun. 2015.
} 
todos en "HACEDORES" (léase tradicionalmente "CREADORES") de situaciones y no consumidores apriorísticamente digitados. El "señalamiento" desencadena, no limita. ${ }^{107}$

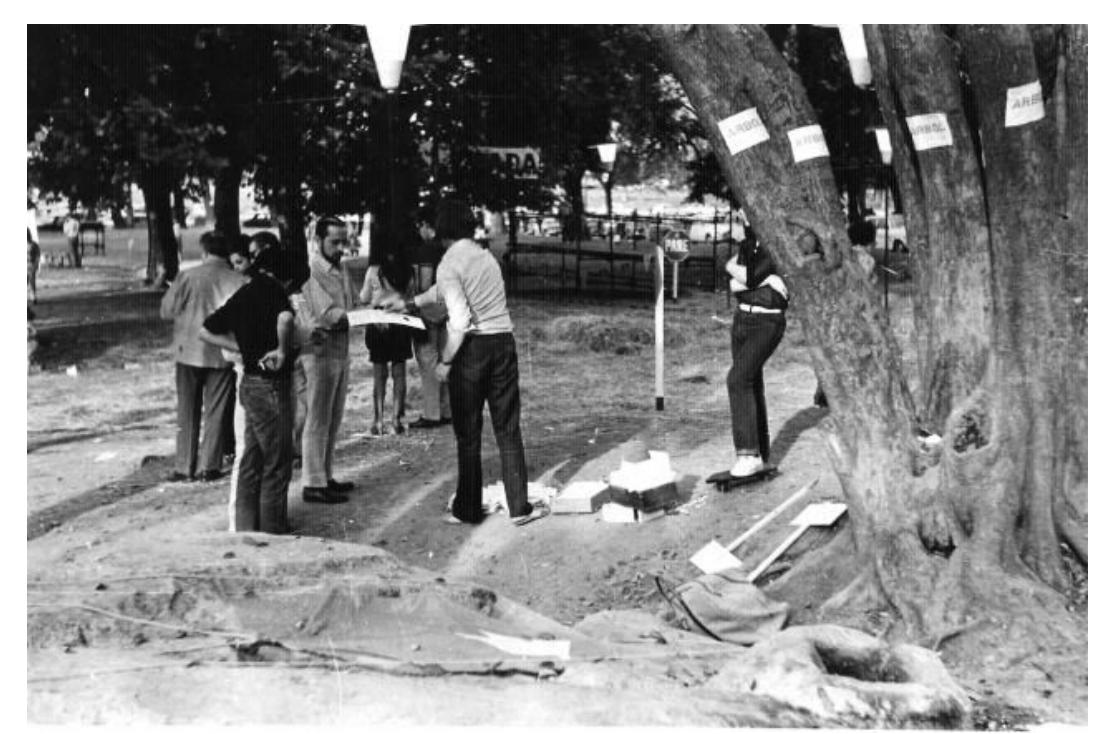

Figura 33 - Escultura, follaje y ruidos.

Edgardo Antonio Vigo em uma ação. Praça Rubén Darío, Buenos Aires, 1970

No mesmo ano, Vigo voltou a ser convidado por Glusberg para outra exposição, junto aos artistas Luis Benedit e Nicolas García Uriburu. Em De la Figuración al Arte de Sistemas, aparece pela primeira vez o conceito arte de sistemas, que logo depois seria aprofundado pelo crítico e marcaria seu dispositivo teórico ao longo da década de 1970. Essa categoria foi utilizada para descrever a trajetória das obras dos três artistas e o modelo utilizado foi o "del artista-antropólogo, portador de una coerencia expandida, que se proyecta como agente de la realidade a la que señala, modifica e documenta" (HERRERA, 2013, p. 20) ${ }^{108}$. A conversão da obra em uma experiência sociológica, por exemplo, tinha como ponto de partida uma reação aos trabalhos de arte pop e da tecnologia, um tipo de contestação que buscava incentivar uma tomada de consciência do artista e estimular a "participación activa del espectador" (GLUSBERG, 1970) ${ }^{109}$. Era também uma crítica ao circuito que comercializava obras de arte tradicionais, reduzindo-as ao gosto do mercado. De acordo com as ideias do

\footnotetext{
107 "Proposta: UM PASSEIO VISUAL PELA PRAÇA RUBEN DARÍO, Buenos Aires, Centro de Arte y Comunicación (CAyC), 1970. A não existência da obra, a não necessidade de estar presente, a efemeridade do estar, a possibilidade 'aberta' a concretizar dissímiles ATOS aos propostos nos converte em FAZEDORES (leiase tradicionalmente CRIADORES) de situações e não consumidores a priori digitados. O señalamiento desencadeia, não limita." (tradução nossa). Em: Hexágono 71, La Plata, 1972.

108 "do artista antropólogo, portador de uma coerência expandida, que se projeta como agente da realidade a qual sinaliza, modifica e documenta." (tradução nossa).

109 "participação ativa do espectador" (tradução nossa).
} 
catálogo da mostra, a fotografia era uma grande aliada da arte de sistemas, proporcionando a informação real por meio do instante do tempo, convertendo o registro da evidência física em um fato artístico.

Veremos adiante que a consolidação de uma arte de sistemas se desdobrará por meio da realização de duas exposições, em 1971 e 1972. Por enquanto, focaremos na constituição teórica e na direção institucional que Glusberg acrescentou ao termo. Nesse momento, a categoria englobava um tipo de produção que se baseava em modelos e linguagens da ciência e se referia a um conjunto de práticas que privilegiavam a arte enquanto processo. $\mathrm{O}$ caráter universal desse "sistema" era um ponto tático aproveitado por Glusberg para implantar um tom internacionalista na produção argentina, além da ambição de ancorá-la no circuito hegemônico. O conceito de sistema fez parte da fortuna crítica desse período e esteve ligado às experimentações artísticas que se articulavam em ideias, processos e informações. A reflexão em torno desse tema teve alguns antecedentes fundamentais que nos auxiliarão no entendimento da apropriação e adaptação local do termo feitas por Glusberg.

$\mathrm{Na}$ Argentina, em 1966, Victor Grippo apresentou um texto chamado Sistema, ${ }^{110} \mathrm{em}$ que procurava explicar o fenômeno artístico a partir da analogia entre o esquema comunicacional emissor-canal-receptor com a tríade artista-obra-público. Nesse sistema sobre o processo de criação, o artista encontrava-se "em seu entorno", a obra era "a concreção a partir de objetos do cotidiano" e o público era analisado de acordo com alguns dados estatísticos: "a maioria das pessoas vira as costas, algumas demonstram algum interesse, outras se mostram céticas [...] e, no final, há um destinatário válido" (GRIPPO, 1966). ${ }^{111}$ A palavra volta a aparecer na mostra Sistemas, de 1970, no CEV - Centro de Experimentación Visual de La Plata, e um dos artistas expositores foi Juan Carlos Romero, que posteriormente estaria ligado ao grupo de artistas do CAYC. Suas criações de elementos seriados com estêncil podiam ser lidas na chave de sistemas formais cujas relações entre as partes formavam uma totalidade dinâmica e aberta. (HERRERA, 2013, p. 14)

Nos EUA, o crítico Jack Burnham publicou um artigo na revista Artforum, em 1968, intitulado Estética de Sistema (System Esthetic), que propunha pensar os sistemas como complexos tributários de uma "cultura supercientífica". O autor chamava a atenção para o paralelo existente entre o modelo de um novo carro, por exemplo, e a "síndrome" da invenção

\footnotetext{
${ }^{110}$ Texto de apresentação da mostra Investigación sobre el processo de creación, na Galeria Vignes, Buenos Aires, 1966.

${ }^{111}$ In: CONTRIM, Cecília; FERREIRA, Glória (Org.). Rio de Janeiro: Jorge Zahar Ed., 2006. Escritos de artistas: anos 60-70. p. 150.
} 
formalista na arte. De modo crescente, os "produtos" da arte e da vida tornaram-se gradativamente irrelevantes quando os problemas passaram a se concentrar nos modos de sustentação da vida biológica na terra, na produção mais correta de modelos de interação social, na compreensão do crescimento da simbiose entre o homem e a máquina e nas prioridades do uso e conservação dos recursos naturais. "We are now in transition from an object-oriented to a systems-oriented culture [...] Thus any situation, either in or outside the contexto of art, may be designed and judged as a system" (1968) ${ }^{112}$. Desse modo surgiu a urgência de se pensar em modelos ou sistemas de interação do homem com o meio e, de acordo com o autor, alguns artistas intuitivamente compreenderam esse processo, entre os quais o grupo ligado ao Minimalismo, como Robert Smithson, Carl André, Donald Judd, Robert Morris, entre outros.

Por sua vez, Glusberg se apoiava na metodologia da ciência e suas possibilidades de abstração para compreender o funcionamento de um conjunto de sistemas. Para tanto, defendia uma relação interdisciplinar com distintas redes teóricas para dar conta da complexidade desses sistemas. Eles podiam ser tanto uma ferramenta criada pelo homem para melhorar a comunicação, quanto a definição de estruturas biológicas não formalizáveis. E seguindo essa linha de raciocínio, escreveu:

"Y así como, sin embargo, la biología analisa dichas estructuras y pretende explicarlas, nosotros lo intentaremos, con el arte como idea, el arte político, el arte ecológico, el arte de proposiciones o el arte cibernético, que hemos decidido llamar - por su denominador común - arte de sistemas" $(\text { GLUSBERG, 1971) })^{113}$

Por meio do entendimento da noção de sistemas, analisava-se os processos criadores dentro de uma coerência interna que estabelecesse relações entre diferentes elementos para a constituição de um conjunto de obras. Essa coerência deveria basear-se nas semelhanças de um discurso artístico e nas suas condições de produção em uma determinada sociedade. As condições de criação similares, mesmo utilizando códigos distintos, formavam um corpus conceitual consistente, que Glusberg denominou como Arte de Sistemas. O código privilegiado para conectar esse conjunto de obras foi a arte conceitual. El arte de sistemas se

\footnotetext{
112 "Nós estamos em uma transição da cultura orientada por objetos para uma cultura orientada por sistemas [...] Por isso, qualquer situação, tanto dentro como fora do contexto da arte, pode ser designada e julgada como um sistema." (tradução nossa). In: https://artforum.com/inprint/issue=196807\&id=32466. Acesso em: 01 jun. 2015. 113 "E assim como a biologia analisa ditas estruturas e pretende assim explicá-las, nós o tentaremos, com a arte como ideia, a arte política, a arte ecológica, a arte de proposições ou a arte cibernética, que decidimos chamar por seu denominador comum - arte de sistemas.” (tradução nossa).
} 
refiere a procesos más que a produtos terminados del "buen arte" (GLUSBERG, 1971). ${ }^{114}$ A proposta teórica do crítico se estruturava, nesse primeiro momento, na natureza da obra de arte enquanto informação e comunicação, afastada de sua concepção objetual.

O conceitualismo, uma das tendências da arte de sistemas, teve lugar de destaque no CAYC em duas exposições: 2.972.453, de 1970, organizada por Lucy Lippard e Jorge Glusberg; e El arte como idea, em 1971, do artista e teórico conceitual norte-americano Joseph Kosuth. A elaboração do discurso de Glusberg se apoiava em muitas das ideias desenvolvidas no circuito internacional de arte conceitual, sobretudo nas reflexões dos convidados citados: Kosuth, Lippard e o inglês Charles Harrison, que também organizou mostras no CAYC, como El arte como idea en Inglaterra, em 1971. O que vale ressaltar é a apropriação estratégica dessa fortuna crítica e seu ajuste ao termo arte de sistemas, circunscrito à produção argentina daquele momento, como veremos adiante.

Joseph Kosuth esteve presente na inauguração da mostra El arte como idea, no CAYC, e na mesma ocasião recebeu o público para falar de sua obra e metodologia. Dois anos antes, o artista publicara o livro Art after philosophy (Arte após a filosofia), no qual empenhava-se em defender a natureza tautológica da condição artística. A linguagem tornouse um meio excepcional de investigação da arte, uma elaboração linguística do ponto de vista da arte e da linguagem. "Qual é a função da arte, ou a natureza da arte?”, perguntava-se Kosuth e prosseguia: "Se dermos seguimento à nossa analogia das formas que a arte assume como sendo linguagem da arte, é possível perceber que uma obra de arte é um tipo de proposição apresentada dentro do contexto da arte, como um comentário sobre a arte" (1969). ${ }^{115}$ A arte conceitual de linhagem linguística teve como principais teóricos, além de Kosuth, os artistas ingleses ligados à Art and Language e foi a que mais acentuou a eliminação total do objeto artístico, priorizando a ideia sobre o produto acabado. A ideia de arte para além do objeto buscou incluir toda e qualquer experiência perceptiva em direção a uma área de investigação filosófica sobre a natureza do conceito de arte (FIZ, 1986, p. 253254). Assim, para falar de arte e de sua autorreferencialidade, era necessário remeter à sua tautologia, ou seja, que a ideia de arte (uma obra) e a arte eram a mesma coisa.

\footnotetext{
114 "A arte de sistemas se refere mais a processos do que a produtos terminados da 'boa arte'." (tradução nossa). ${ }^{115}$ In: CONTRIM, Cecília; FERREIRA, Glória (Org.). Rio de Janeiro: Jorge Zahar Ed., 2006. Escritos de artistas: anos 60-70. p. 219.
} 
Na gacetilla da mostra, Glusberg, além de introduzir o trabalho conceitual de Kosuth dentro de uma "área experimental de investiganciones", descreveu, de modo didático, as obras que o artista desenvolveu em Buenos Aires:

Un cartel de 4 m x 2 m en Florida 688, outro en Florida 939, un anuncio en La Nación de fecha 16 de junio [...] volantes distribuídos en la calle y las galerias fueran parte del sistema que exhibe Kosuth en Buenos Aires, así como el cartel de neón de 5m de largo que se exhibe en el segundo subsuelo, que habla sobre sí mismo, ya que aclara en su texto que es de neón, que funciona con eletricidade, que da luz, que está escrito en español, que está realizado em vidrio, que son letras, de color verde, y que en total son ocho: NEON ELETRICIDAD LUZ ESPAÑOL VIDRIO LETRAS VERDE OCHO (1971). ${ }^{116}$

Em 1970, o CAYC recebeu a exposição organizada pela crítica norte-americana Lucy Lippard. ${ }^{117}$ Como parte da divulgação do programa institucional, o CAYC circulou gacetillas informativas sobre o que era arte conceitual e sobre os artistas participantes. "El arte conceptual es un arte de documentación [...] ha objetivizado la información, es decir, no centra el interés en el contenido de la obra de arte, sino sobre la naturaliza de la información misma" ${ }^{, 18}$, explicava Glusberg.

O catálogo da exibição feita por Lippard era o terceiro de uma série de volumes organizados com fichas de arquivo, cujo título era escolhido de acordo com o número da população da cidade na qual a exposição era montada. As anteriores foram: Seattle - 557.087; Vancouver - 995.000; e Buenos Aires - 2.972.453. No texto, a crítica reiterava que o CAYC não tinha nenhum vínculo com as instituições que receberam as duas mostras prévias e que, no entanto, a junção dos três catálogos com a fichas de arquivos formavam uma "única

\footnotetext{
116 “Um cartaz de 4 m x 2 m na (rua) Florida 688, outro na Florida 939, um anúncio no (jornal) La Nación com a data 16 de junho, [...] requerimentos distribuídos na rua e na galeria foram parte do sistema que exibe Kosuth em Buenos Aires, assim como o cartaz de neon de $5 \mathrm{~m}$ de comprimento que se exibe no segundo subsolo, que fala sobre si mesmo, já que esclarece em seu texto que é de neon, que funciona com eletricidade, que dá luz, que está escrito em espanhol, que está realizado em vidro, que são letras, de cor verde, e que no total são oito: NEON, ELETRICIDADE, LUZ, ESPANHOL, VIDRO, LETRAS, VERDE, OITO.” (tradução nossa). GLUSBERG, Jorge. Joseph Kosuth - El arte como idea. Buenos Aires: CAYC, 1971. ICCA - Documents of 20th-Century Latin American and Latino Art. Registro: 747930. Acesso em 11 jun. 2015.

${ }^{117}$ Lippard havia visitado a Argentina dois anos antes, como parte do júri da mostra Materiales, nuevas técnicas, nuevas expresiones, no Museu Nacional de Bellas Artes. Os premiados foram dois artistas de tendências conceituais: Jorge Carballa e David Lamelas.

${ }^{118}$ A arte conceitual é uma arte de documentação [...] objetiva a informação, que dizer, não centra o interesse no conteúdo da obra de arte, mas sobre a natureza da informação mesma (Tradução nossa). GLUSBERG, Jorge. Arte Conceptual. CAYC, 1970. ICCA - Documents of 20th-century Latin American and Latino Art. Registro: 747375. Acesso: 11-06-2015. É curioso apontar que várias questões sobre a arte conceitual explanadas nessa gacetilla foram repetidas de forma idêntica em outras ocasiões, como na divulgação das exposições de Kosuth e Charles Harrison, mencionadas anteriormente.
} 
entidade crescente". As transformações sociais, a política radical, as técnicas de terapia em grupo e a falta de fé nas instituições culturais eram um dos pontos destacados por Lippard que acarretaram na emergência de uma "arte desmaterializada". Essa era uma das características da chamada "arte conceitual" ou arte como ideia que

incorpora a menudo otras disciplinas; sus soluciones pueden ocurrir en forma de páginas dactilografas, de secuencias fotográficas, de representaciones de actos públicos o de una premissa matemática. Si la obras incluídas en esta muestra y en otras similares, poseen algo en común, lo es la ideia, que no es nueva, de que el arte provee un marco dentro del cual enfocar aspectos de vida (de los cuales, la naturaleza interna del arte mismo no es menos importante). ${ }^{119}$

Em uma das fichas do catálogo, Glusberg usa o termo "desmaterializado" para falar sobre a trajetória artística que vinha se transformando desde o final da década anterior. As possibilidades abertas por essa nova arte eram tão grandes quanto a dos meios tradicionais, como o campo da pintura e escultura. E conclui, ressaltando que "[...] el arte desmaterializado [...] se ocupa de llevar a la conciencia del observador, una serie de áreas de experiencia $[\ldots]^{\prime 120}$. O termo ${ }^{121}$ faz referência ao conhecido artigo de Lucy Lippard e John Chandler, The desmaterialization of art $^{122}$, publicado em 1968. Segundo os autores, a perda do interesse pela evolução física da obra de arte havia provocado uma profunda desmaterialização da arte, sobretudo, da arte objetual.

\footnotetext{
119 "incorpora outras disciplinas, suas soluções podem ocorrem em forma de páginas datilografadas, de sequencias fotográficas, de representações de atos públicos ou de uma premissa matemática. Se as obras incluídas nesta mostra e em outras similares possuem algo em comum, é a ideia, que não é nova, de que a arte provém de um marco dentro da qual se enfoca aspectos da vida (dos quais, a natureza interna da arte mesma não é menos importante." (Tradução nossa). In: Centro de Arte y Comunicación. 2.872.453. (cat. exp.), Buenos Aires: CAYC, 1970. (09035) Pasta CAYC - Biblioteca Lourival Gomes Machado.

120 " [...] a arte desmaterializada [...] se ocupa em levar a consciência do observador a uma série de áreas de experiência (Tradução nossa). In: Centro de Arte y Comunicación. 2.872.453. (cat. exp.), Buenos Aires: CAYC, 1970. (09035) Pasta CAYC - Biblioteca Lourival Gomes Machado.

${ }^{121}$ Em Nuevos Estudios Masottianos, Ana Longoni nos recorda que um ano antes do célebre artigo de Lippard, o argentino Oscar Masotta fez uma conferência no Di Tella, intitulada Después del Pop, nosostros desmaterializamos. Masotta usa o termo que o russo El Lissitsky utilizou para descrever a capacidade expressiva do livro como multiforme, e que a "desmaterialização é a característica da época" na qual as novas técnicas comunicacionais provocam a diminuição da matéria física e o aumento da "energia liberada". Masotta retoma essa ideia, segundo Longoni, para pensar o processo da arte e da comunicação. In: LONGONI, Ana. "Nuevos Estudios Masottianos". Revista Ramona 45, 2004, p. 21.

${ }^{122}$ Texto publicado originalmente em Art International, v. 12, n. 2, em 1968.
} 


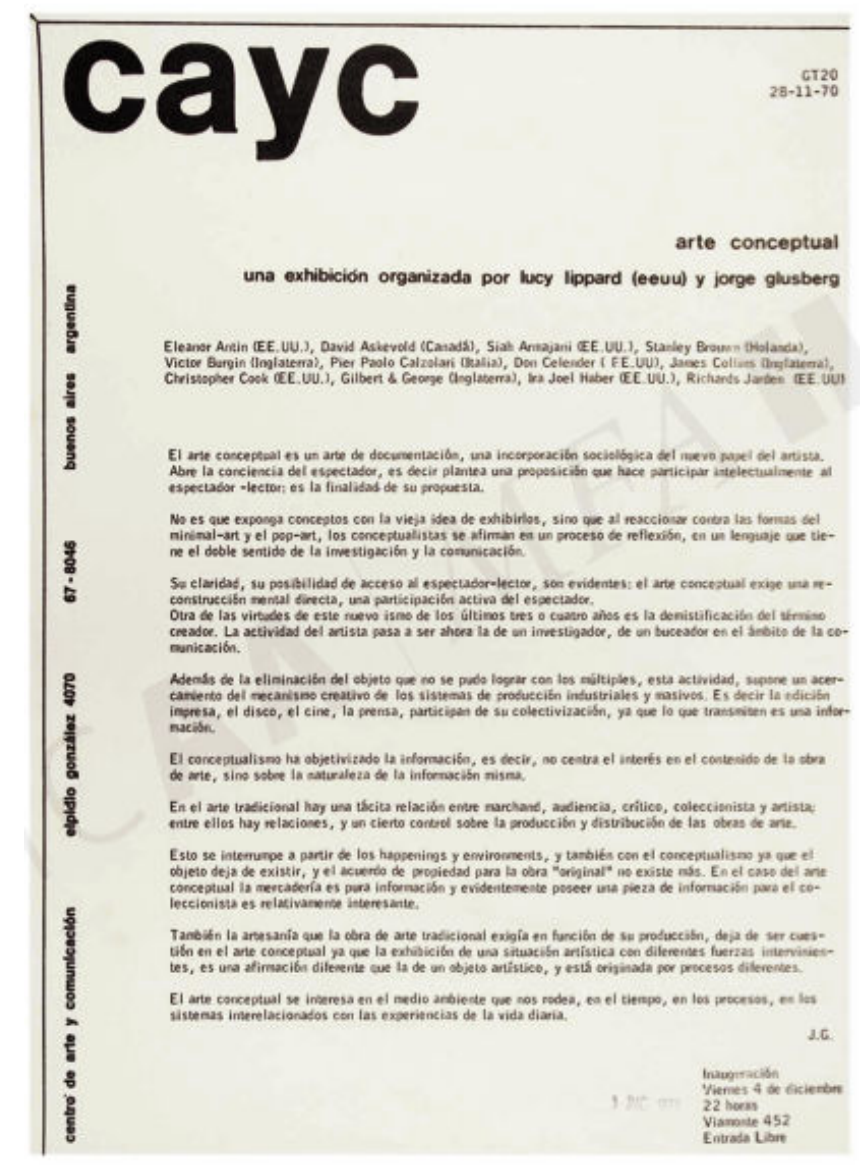

Figura 34 - Una exhibición organizada por Lucy Lippard y Jorge Glusberg

Gacetilla GT 28-11-70. ICCA - Documents of 20th-Century Latin American and Latino Art

A mudança da ênfase na arte como produto para a arte como ideia

ha liberado al artista de limitaciones reales, tanto económicas como técnicas. Es posible que obras de arte que ahora no pueden realizarse por falta de medios puedan concretarse em algún momento en el futuro. El artista como pensador, sujeto a ninguna de las limitaciones a las que está sujeto el artista como hacedor, puede proyectar un arte utópico y visionario que no sea menos arte que las obras concretas (LIPPARD; CHANDLER, 1968) ${ }^{123}$

A referência dos autores à ampliação da liberdade artística acarretada pela ênfase na arte como ideia, que liberou o artista dos obstáculos econômicos para realizar trabalhos, foi uma questão fundamental para os artistas latino-americanos. Inclusive, podemos analisar algumas divergências entre a arte conceitual realizada no circuito internacional, da qual Lippard e Chandler se destacam, entre outros, como autores consagrados, e as produções

\footnotetext{
123 “tem liberado o artista de limitações reais, tanto econômicas como técnicas. É possível que as obras de arte que agora não se realizem por falta de meios possam concretizar-se em algum momento no futuro. O artista como pensador, sujeito a nenhuma das limitações nas quais está o artista como fazedor, pode projetar uma arte utópica e visionária que não seja menos arte que as obras concretas." (tradução nossa).
} 
desenvolvidas nos países da América do Sul. Os artistas citados pelos críticos no artigo mencionado, tornaram-se os porta-vozes da arte conceitual canônica de matriz anglo-saxônica e estariam na gênese desse movimento: Robert Rauschenberg, Robert Morris, Sol LeWitt, Mel Bochner, Joseph Kosuth etc. A arte conceitual ascendeu em um espaço de vanguarda cuja conjuntura fora marcada pela crítica ao legado do modernismo, sobretudo, ao imperativo da visualidade e da autonomia artística. E o deslocamento da obra da parede para o espaço tridimensional resultaria em uma arte de Specific Objects ${ }^{124}$, nome do texto escrito por Donald Judd, considerado o manifesto da arte minimalista, outra gênese dessa arte conceitual hegemônica. Judd afirmava que a produção artística de sua geração tinha uma característica basal apoiada no trabalho tridimensional, inscrito em um espaço real anti-ilusionista.

Três dimensões são o espaço real. Esse fato elimina o problema do ilusionismo e do espaço literal [...] o que significa libertar-se [...] das mais significativas e contestáveis relíquias da arte europeia. [...] O espaço real é intrinsecamente mais potente e específico do que a pintura sobre uma superfície plana (JUDD, 1965). ${ }^{125}$

As palavras que destacamos dos textos de Judd, Lippard e Chandler - "espaço real”, “econômicas" e "pensador" versus "fazedor" são termos fundamentais que foram amplamente discutidos pelos artistas latino-americanos e analisados sob outras perspectivas, em cujos desdobramentos podemos identificar as principais diferenças entre a produção de caráter conceitual local e a hegemônica. Esses pontos serão discutidos no próximo tópico.

\section{1- UMA PROBLEMÁTICA PRÓPRIA}

As palavras selecionadas são cruciais para compreendermos a complexidade e a heterogeneidade das práticas artísticas latino-americanas que se desenvolveram sob a égide de poéticas "subterrâneas" (FREIRE, 2011, p.42). Estas formaram a base de um programa de intervenções artísticas e políticas que fosse capaz de transformar a sociedade, tornando-se uma demanda emergencial marcada pela tomada de consciência sócio-política de muitos

\footnotetext{
${ }^{124}$ Texto originalmente publicado em Arts Yearbook 8, em 1965.

${ }^{125}$ In: CONTRIM, Cecília; FERREIRA, Glória [Org.]. Rio de Janeiro: Jorge Zahar Ed., 2006. Escritos de artistas: $\operatorname{anos} 60-70$. p. 103.
} 
artistas do período. Nesse sentido, o interesse primordial do artista pela forma do objeto enquanto potencializador da criação artística se tornava cada vez mais distante. Nessa chave, o espaço real para Judd, por exemplo, assumia, sobretudo, um viés formalista. Partindo da própria análise do artista de que "qualquer coisa em três dimensões pode ter qualquer forma", privilegiava a noção espacial como um palco limitado à experimentação "de todo o tipo de materiais e cores".

O espaço real, do lado de cá, representava um campo complexo determinado pelos devastadores efeitos da ditadura militar no tecido social, pela falência dos programas modernizadores da Guerra Fria, pela instabilidade econômica, pela violação dos direitos humanos e por toda a debilidade da herança colonial. Assim sendo, é importante se ater às investigações estéticas, éticas e políticas, considerando que as duas últimas instâncias, atreladas ao fazer estético, foram fundamentais no ato de criação durante os anos de chumbo das ditaduras militares. A estética não deveria estar restrita somente à inovação da linguagem visual, mas inserida num campo de ação mais amplo que exigia uma postura ética e política. Essa tríade foi, portanto, o ponto de partida das produções artísticas inscritas e potencializadoras do espaço real.

O privilégio do pensar sobre o fazer, evidenciado por Lippard e Chandler, apontava para a lógica ultrapassada do paradigma modernista da ênfase no manual como método extraordinário da criação artística. Em contrapartida, a dimensão do fazer foi de extrema importância e adquiriu outro sentido: da ação e da proposição que buscavam ativar a obra, o espectador e por sua vez, o espaço real. O artista do fazer ou do acionar era o mesmo que tinha consciência de sua participação na sociedade, transformando-se em um agente capacitado para investigar a complexidade do mundo social.

Por último, a arte como ideia que liberou o artista de limitações econômicas e técnicas representou um marco na arte como processo e na utilização de materiais precários e não convencionais. Se os artistas italianos da Arte Povera evocaram a era pré-industrial com o uso de materiais comuns como terra, rochas, cordas, papel, panos etc., obras "pobres" feitas por "artistas que con su propio actuar se proponen recuperar esa posibilidad de proyectarse libremente" (CELANT, 2011, p.102) ${ }^{126}$; a precariedade dos materiais utilizados, coerentes com a situação socioeconômica, tornou-se uma alternativa crítica para os artistas latino-

126 “artistas que com seu próprio atuar se propuseram recuperar essa possibilidade de projetar-se livremente." (Tradução nossa). CELANT, Germano. Arte Povera. Apuntes para una guerrilla. In: ALONSO, Rodrigo. Sistemas, acciones y procesos. 1965-1975. Buenos Aires: Fund. Proa, 2011. 
americanos. Nesse momento, era necessário estabelecer a relação entre o valor econômico e a sua relação com os círculos de privilégio (FREIRE, 2006, p 26). Um exemplo são as trouxas ensanguentadas de carne, ossos e sangue que Artur Barrio espalhou anonimamente pela cidade de Belo Horizonte, evocando o ambiente de tensão associado aos assassinatos do regime militar e dos grupos de extermínio no Brasil. Na revista Hexágono 71, Edgardo Antonio Vigo escreveu um artigo intitulado UNA FORMA DE "REAL" ARTE POBRE, posicionando a "arte pobre" europeia e norte-americana como uma necessidade de transformação imposta pela "dinâmica comercial", em contraposição a uma real arte pobre latino-americana, que por sua falta de meios surgia por carência e não por excesso, como na Europa.

Jorge Glusberg também articulara a produção ligada ao CAYC na chave de uma "arte pobre" orientada pelas reais condições de produção dos artistas latino-americanos. A partir de 1972, gradualmente, o CAYC foi mudando sua agenda institucional, incluindo mostras e colóquios cujos temas centrais orbitavam entre as questões políticas e de ordem ideológica. Dessa maneira, o primeiro eixo de articulação teórica ligada à arte de sistemas sofreu algumas reformulações que marcaram o programa do CAYC ao longo da década de 1970. Se nos anos antecedentes, a instituição buscou associar a categoria arte de sistemas às investigações conceituais internacionais, atualizando a produção local com algumas experiências de arte e tecnologia pautadas nas teorias da informação, a noção ganhou uma faceta geopolítica de forte retórica regional cuja pretensão era promover uma arte de sistemas latino-americana. Quer dizer, identificar uma problemática própria aos artistas locais, legitimando essas práticas como formas de ação política, frente à realidade instável marcada pela ascensão dos regimes militares. Esse contexto, de acordo com Mariana Marchesi, somado ao perfil politizado de diversos integrantes ligados ao CAYC, consolidou a direção que o Centro seguiria nos anos posteriores. E essa foi uma situação que Glusberg soube aproveitar como grande oportunidade (2011, p. 66).

Em 1972, o CAYC participou da III Bienal de Coltejer, em Medellín, com a exposição Hacia un perfil del arte latinoamericano. Na apresentação da mostra, Glusberg buscava definir o perfil da arte latino-americana da seguinte maneira:

No existe un arte de los países latinoamericanos, pero sí una problemática propia, consecuente con su situación revolucionaria. [...] Nuestros artistas tomaron conciencia de los requerimientos de sus realidades y se plantearon respuestas regionales, consecuentes com el cambio de las áreas de la vida humana que se proponen los subprovilegiados de hoy, que pensamos son los 
potencialmente privilegiados de mañana (GLUSBERG, 1972.) ${ }^{127} \mathrm{E}$ assim, o crítico demarcava as práticas artísticas locais, sob a retórica do regionalismo, afirmando que, por meio da arte como ideia, os artistas haviam tomado consciência da realidade nacional, e por consequência, procuravam respostas regionais para as suas demandas. Para o seu programa de arte latino-americana, os artistas deveriam ressaltar a realidade colonial e tributária das grandes metrópoles, revelando a situação de dependência social e cultural.

A estratégia encontrada por Glusberg para consolidar essa nova direção crítica foi criar um dispositivo expositivo unificado, que considerava a exposição como uma tipologia ou um "sistema" para divulgar e circular obras de arte com o mínimo de recursos possível. Segundo Herrera (2013, p.22), isso implicava em padronizar desde as etapas da produção das mostras à execução dos artistas: o desenho expositivo, a montagem, a iluminação, as legendas das obras, os textos didáticos etc. Essa metodologia concebida por Glusberg baseava-se em um sistema econômico facilmente reproduzível que incluía estampas do mesmo tamanho com fichas de identificação (autor, título da obra e ano) que eram montadas sobre uma parede ou um painel. Distante da lógica institucional inicial, que apoiava a experimentação artística por meio de máquinas e computadores de última tecnologia, o novo programa do CAYC traçava um método "pobre", em sintonia com a realidade econômica da região, "propio de nuestra imposibilidad de competir con medios tecnológicos y posibilidades económicas que aún no disponemos" (GLUSBERG, 1972). ${ }^{128}$

Hacia um perfil del arte latinoamericano também foi importante por apresentar oficialmente o Grupo de los Trece ${ }^{129}$, um grupo de artistas que trabalharia sob a coordenação de Jorge Glusberg. O diretor do CAYC baseou-se nas propostas e nos fundamentos metodológicos do "teatro pobre" de Jerzy Grotowski para a fundação do Grupo. Os postulados de Grotowski ultrapassaram as barreiras teatrais e serviram como importante referência aos princípios estéticos das vanguardas artísticas das décadas de 1960 e 1970 que

\footnotetext{
127 “Não existe uma arte dos países latino-americanos, mas sim uma problemática própria consequente com a sua situação revolucionária. [...] Nossos artistas tomaram consciência das necessidades de suas realidades e buscaram respostas regionais coerentes com a mudança das áreas da vida humana que são propostas pelos subprivilegiados de hoje, que serão os potencialmente privilegiados de amanhã." (tradução nossa).

128 "próprio de nossa impossibilidade de competir com meios tecnológicos e possibilidades econômicas que ainda não dispomos." (tradução nossa).

${ }^{129}$ Em sua primeira formação, em 1971, o Grupo esteve composto pelos artistas: Alfredo Portillos, Jorge Glusberg, Jacques Bedel, Vicente Marota, Carlos Ginzburg, Victor Grippo, Julio Teich, Luis Fernando Benedit, Juan Carlos Romero, Gregorio Dujovny, Luis Pazos, Jorge Gonzalez Mir e Horacio Zabala. Até meados da década, os treze integrantes originais se reduziram a nove, por conta de exílios, diferenças políticas e alterações na dinâmica do grupo. Glusberg convidara outros dois artistas para o Grupo de los Trece: Clorindo Testa, Leopoldo Maler. Em 1975, transformou-se em Grupo CAYC e posteriormente os artistas que continuaram reunidos foram: Bedel, Benedit, Grippo, Glusberg, Maler, Marotta, Gonzalez Mir, Portillos e Testa.
} 
buscavam fazer da arte um meio de conhecimento e participação, além da aproximação com o âmbito social (GLUSBERG, 1985, p. 129). O diretor teatral polonês criou um modelo de teatro-laboratório que gradualmente eliminava quaisquer intenções teatrais: maquiagem, efeitos de luz, cenário, trilha sonora, figurino etc. A renúncia de todos os elementos tradicionais da linguagem teatral e da própria cena ou ato artístico visava focar na comunicação total entre o ator e o espectador, favorecendo um diálogo completo entre ambos. Sobre a investigação da natureza teatral impulsionada pelo polonês, o diretor inglês Peter Brook escreveu:

Posiblemente, el de Grotowski es el único teatro de vanguardia cuya pobreza no es un obstáculo, donde no poseer dinero no es una excusa para la utilización de medios inadecuados que automáticamente destruyen los experimentos. En el teatro de Grotowski, como en los auténticos laboratorios, los experimentos son cientificamente válidos en tanto que se respetan las condiciones esenciales (BROOK apud GLUSBERG, 1985, p. $128)^{130}$.

Grotowski foi convidado para participar de uma palestra no CAYC, em 1971. Glusberg conta que as ideias do "teatro pobre" polonês foram uma das principais origens do Grupo de los Trece, inclusive, o número de cadeiras da companhia teatral do diretor - treze serviu de inspiração para o nome do grupo de artistas argentinos. As propostas de um laboratório grotowskiano se adequavam aos direcionamentos teóricos que Glusberg fomentava na mesma época e serviram como base estética do programa institucional do CAYC. Se no "teatro pobre" os elementos indispensáveis em uma sala vazia eram a comunicação direta com o espectador e a eliminação dos artifícios teatrais, seu correlato argentino pautava-se na produção de uma arte ideológica que ativasse o meio social com o uso de materiais simples e econômicos, como o papel heliográfico.

\footnotetext{
130 “Possivelmente, o de Grotowski é o único teatro de vanguarda cuja pobreza não é um obstáculo, onde não possuir dinheiro não é uma desculpa para a utilização de meios inadequados que automaticamente destroem os experimentos. No teatro de Grotowski, como nos autênticos laboratórios, os experimentos são cientificamente válidos na medida em que se respeitam as condições essenciais.” (tradução nossa).
} 


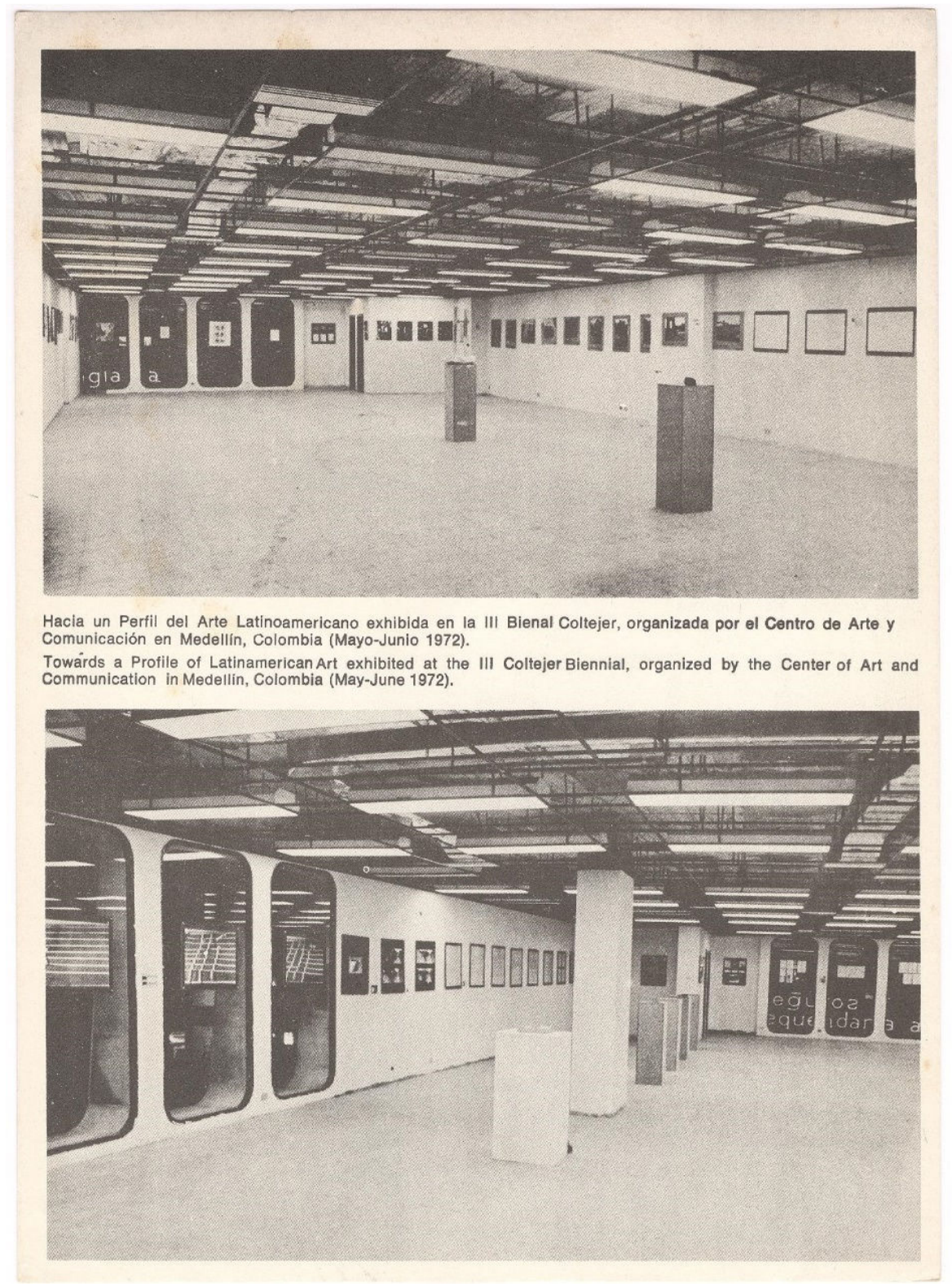

Figura 35 - Vista da mostra Hacia un perfil del arte latinoamericano (cat. exp.) Bienal Coltejer, Medellín, 1972

A "problemática própria" descrita por Glusberg como eixo articulador da produção latino-americana, marcava desse modo, uma nova identidade ao termo arte de sistemas e esquematizava as características de um tipo particular de arte conceitual local, em consonância com a realidade econômica e social da região. A ideia de trabalhar em grupo a partir de um método à maneira de um laboratório interdisciplinar grotowskiano ou o estímulo ao ato criativo com o mínimo de recursos, como no "teatro pobre", foram eixos que sedimentaram as práticas do CAYC, sobretudo, desde 1972. 
Segundo Pineau (2007, p. 29), nessa mesma época, o CAYC criou uma Escuela de Altos Estudios (EAE) com objetivo de formar um novo organismo dentro da instituição, cujas atividades se vinculassem diretamente às problemáticas abordadas nas exibições. Diversos intelectuais foram convidados para cursos e palestras na EAE, como Néstor García Canclini e Eduardo Lipovetzky, por exemplo, com o intuito de promover estudos interdisciplinares sobre a realidade argentina e latino-americana nos campos da arte e da comunicação. Um dos primeiros seminários da Escola foi conduzido por Canclini e se intitulava Vanguardias estéticas, estructura social y cultura popular. ${ }^{131} \mathrm{O}$ teórico argentino propunha a análise de obras produzidas por artistas ligados ao CAYC, os novos modos de expressão artística e as possíveis relações com a arte popular. Vale ressaltar que as investigações de Canclini foram pioneiras nos estudos sobre uma sociologia da arte latino-americana e sobre as problemáticas culturais desse período (MARCHESI, 2013, p. 70).

Desde Hacia un perfil del arte latinoamericano, o uso do papel heliográfico tornou-se um dos suportes privilegiados de exibição e circulação das obras agenciadas pelo CAYC. Sobre esse novo canal de comunicação, os artistas conscientes de suas realidades nacionais, se manifestavam sob o prisma da arte como forma ideológica, em compasso com a sentença já mencionada: "não existe uma arte dos países latino-americanos, mas uma problemática própria”. Uma das obras heliográficas da exposição evidenciava o ambiente de confrontação proposto pelos artistas. Proyecto de monumento al prisionero político desaparecido, do artista platense Luis Pazos, e uma de suas cinco proposições para uma arte latino-americana, publicada no catálogo: "fazer da arte a conscientização da realidade", indicavam algumas das premissas do CAYC e das particularidades das produções locais de caráter conceitualista. É válido mencionar que Pazos, nesse ato de previsão trágica, assinalava o destino de milhares de civis durante as ditaduras na América Latina.

\footnotetext{
${ }^{131}$ Os mesmos problemas analisados pelo teórico argentino haviam sido publicados alguns meses antes em um livro homônimo, pelo Centro Editor de América Latina.
} 


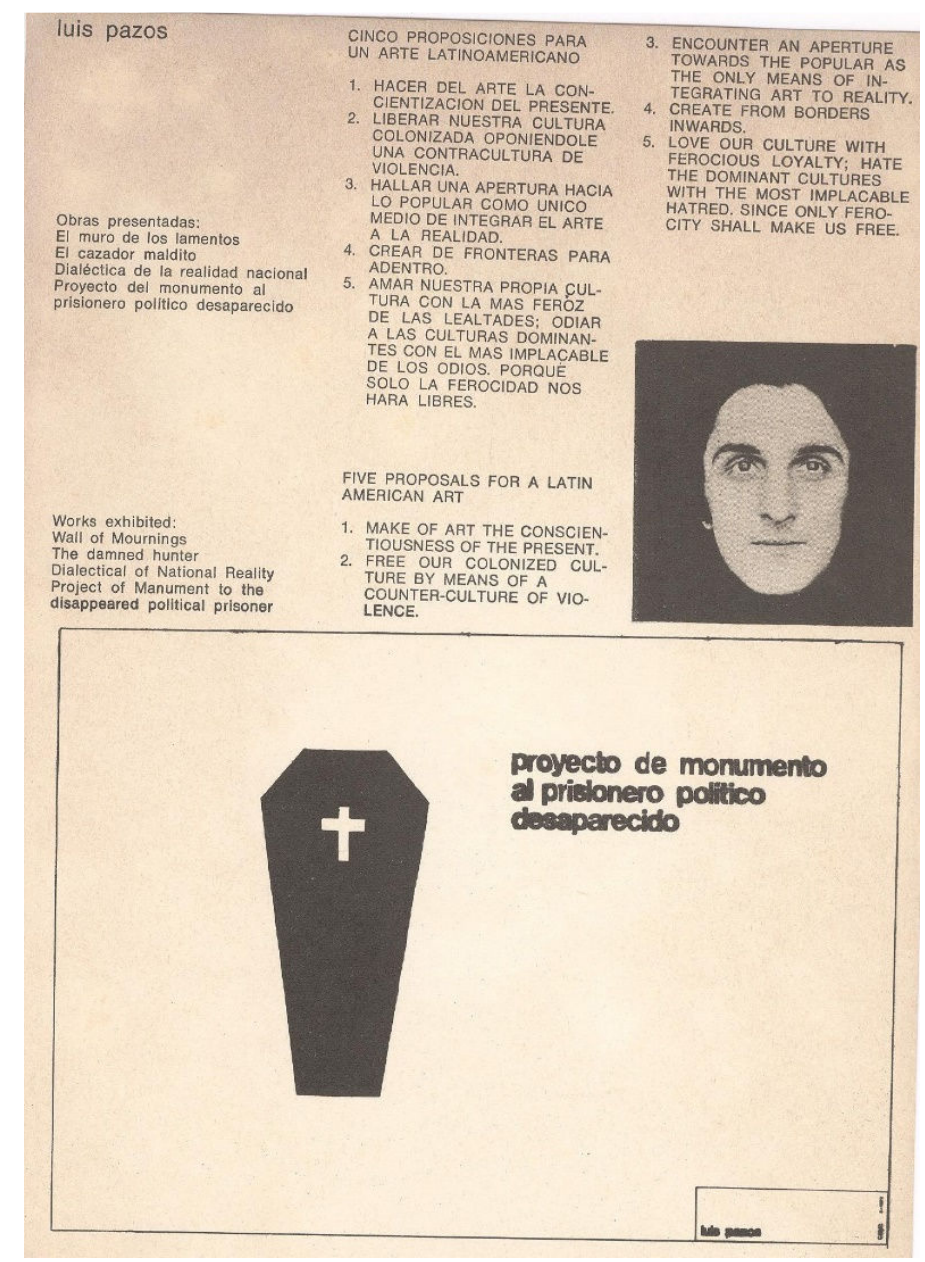

Figura 36 - Obras apresentadas na mostra Hacia un perfil del arte latinoamericano (cat. exp.) Luis Pazos, 1972

Não foram convidados apenas latino-americanos para Hacia un perfil..., mas artistas de diversas nacionalidades como Dick Higgins, Ken Friedman, Marcel Alocco, Guerrilla Art Action Group, entre outros. Essa lista heterogênea destoava do título da exposição, que buscava traçar um perfil da arte latino-americana. O crítico argentino Rodrigo Alonso (2011) levantou essa questão com a seguinte pergunta: o que faziam os artistas europeus e norteamericanos em uma mostra que se propunha construir um perfil da arte regional? Alonso nos recorda do contexto da época, no qual diversos artistas se reuniram na ocasião do boicote à $\mathrm{X}$ Bienal de São Paulo, de 1969, como resposta à censura e repressão do regime militar brasileiro. E levanta uma hipótese de que se poderia pensar, nesse momento, que diversos artistas internacionais se identificaram com esses manifestos e boicotes aos conflitos militares crescentes na América Latina. Assim sendo, se incluíram nesses protestos e nos movimentos de resistência latino-americanos, como se fossem parte constituinte desses países. "Son 
tempos en los que cualquiera podía sentirse, todavia sin demasiada culpa, un poco vietnamita, cubano, catalán, chino, mexicano o francês" (ALONSO, 2011, p. 22). ${ }^{132}$

Glusberg registrou as práticas ligadas ao CAYC dentro do que ele próprio denominou por conceitualismo ideológico, uma versão regional da arte conceitual que estaria em sintonia com a situação periférica e com a dinâmica social da região, ou seja, com a sua "problemática própria”. Um dos pontos de partida era a metodologia da arte como ideia, procurando promover um sistema conceitual mediante à condição real do meio social no qual viviam os argentinos. Sendo assim, as vertentes conceituais na América Latina operariam sob outra política de visibilidade, imprimindo uma nova lógica às propostas tautológicas e auto referenciais exportadas pelos centros hegemônicos. Para Glusberg, o conceitualismo ideológico estaria no marco dessas inversões conceituais:

Esta afirmación del arte como mercancía apoyada por la estética tradicional no es vigente [...] pero lo que importa es la apertura que propone este conceptualismo ideológico de los artistas argentinos como una forma que emerge como consecuencia de una problemática regional que utiliza una metodologia común a diferentes contextos. Este es el valor de esta nueva avanzada artística argentina (GLUSBERG, 1972) ${ }^{133}$.

Para aprofundar o marco ideológico das práticas argentinas delimitadas por Glusberg, é fundamental compreendermos os limites entre arte conceitual e conceitualismos. A arte conceitual foi um movimento internacional com duração definida na história da arte contemporânea, que durou aproximadamente entre as décadas de 1960 a 1980. Os conceitualismos seriam, de acordo com Cristina Freire (2006, p. 8), uma tendência crítica à arte objetual que inclui diferentes proposições como arte postal, videoarte, performance, intervenções urbanas, livros de artista, xerox, mapas, instalações etc. Quer dizer, uma série de estratégias que colocaram em cheque a fetichização do objeto artístico, assim como os seus sistemas de produção e distribuição. Seguindo as considerações sobre as práticas conceitualistas, a crítica porto-riquenha Mari Carmen Ramírez (2001) abordou as seguintes questões: é possível postular versões regionais autônomas daquilo que, de maneira geral, foi entendido como um fenômeno da cultura dominante? Quais aspectos caracterizariam as

\footnotetext{
132 "São tempos em que qualquer um poderia sentir-se sem culpa um pouco vietnamita, cubano, catalão, chinês, mexicano ou francês." (tradução nossa).

133 "sta afirmação da arte como mercadoria apoiada por uma estética tradicional não é vigente [...] mas o que importa é a abertura que propõe este conceitualismo ideológico dos artistas argentinos como uma forma que emerge como consequência de uma problemática regional que utiliza uma metodologia comum em diferentes contextos. Este é o valor deste novo avanço artístico argentino." (tradução nossa).
} 
particularidades das versões conceitualistas latino-americanas? Sobre a natureza das contribuições da América Latina para as realizações de um conceitualismo global, Ramírez afirmou que essas especificidades deveriam ser lidas como

respostas locais às contradições originadas pelo fracasso após a Segunda Guerra Mundial, dos projetos de modernização e dos modelos artísticos preconizados para a região. [...] dessa perspectiva, a emergência do conceitualismo na América Latina não só surgiu paralelamente a importantes desenvolvimentos da arte conceitual central como também, em muitos exemplos-chave, os antecipou. [...] considero que, ao fazer da política e da ideologia o ponto de partida para o questionamento radical da arte enquanto instituição, os conceitualistas na América Latina produziram algumas das respostas mais criativas do século $\mathrm{XX}$ ao problema da função da arte, levantado pela primeira vez por Marcel Duchamp (RAMÍREZ, 2001, p.186) $)^{134}$

Nosso recorte se debruça sobre as práticas conceitualistas na América Latina que, como vimos, tiveram como característica uma forte inclinação política, distanciando-se assim, das investigações acerca da natureza do objeto artístico como ponto de partida único. Em Del arte objetual al arte de concepto, de 1972, o espanhol Simón Marchán Fiz foi um dos primeiros historiadores de arte fora da Argentina a introduzir as mostras do CAYC, como 2.972.453 e Arte de Sistemas, de 1970 e 1971, em uma narrativa da arte conceitual inserida em um momento no qual ainda não era possível delimitar com claridade "las fronteras y las facetas diversas de la actividad conceptual” (FIZ, 1972, p.209) ${ }^{135}$. Junto às duas exposições, citou algumas mostras que se tornaram emblemáticas para a história da arte conceitual canônica, como Conceptual Art, Conceptual Aspects e When Attitudes Become Form, ambas de 1969. Em edições posteriores desse livro (1986), Marchán Fiz agregou novas informações ao capítulo sobre arte conceitual, buscando traçar a diferença entre a produção anglo-saxônica do conceitualismo da Espanha e, sobretudo, da Argentina. Sua peculiaridade estaria na forma como alargaram a crítica institucional realizada por distintos artistas internacionais para uma análise das questões políticas e sociais. Marchán Fiz esquematizou as diferentes matrizes conceituais: linguística e tautológica; crítica; conceitual mística; e uma vertente que ia além da tautologia, na qual estaria inscrita um tipo de conceitualismo ideológico, entendido não como força produtiva pura, mas social (FIZ, 1986, p. 269). Sobre essa última vertente - Más allá de la tautologia - o espanhol escreveu:

\footnotetext{
${ }^{134}$ Tactics for thriving on adversity: conceptualism in Latin American, 1960 - 1980. Este texto foi originalmente publicado no catálogo da exposição Global Conceptualism: Points of origin, 1950s-1980. Queens Museum of Art, NY, 1999.

135 "as fronteiras e as diversas facetas da atividade conceitual." (tradução nossa).
} 
Esta necesidad se ha dejado sentir en diversos países, sobre todo en aquellos donde, tras una primera apropriación mimética de las tautologias y del colonialismo cultural, estas prácticas se están viendo sometidas a grandes tensiones. Tensiones provocadas por las contradicciones sociales peculiares. En este sentido, España y Argentina son dos ejemplos de lo que un conceptualismo puro consideraria una versión degenerada del mismo, en especial si uno se detiene en sus propostas. En Argentina se ha hablado de un conceptualismo ideológico (FIZ, 1986, p. 269) ${ }^{136}$

A menção a um conceitualismo ideológico estaria ligada diretamente à figura de Glusberg, que usou o termo no catálogo da exposição Arte e Ideología - CAYC al Aire Libre, de 1972, que veremos logo a seguir. O que nos interessa é analisar os meandros dessas vertentes conceitualistas e a sua recepção crítica na Argentina, buscando evitar contraposições redutoras entre essas práticas, uma vez que fizeram parte de um campo complexo e heterogêneo.

Devemos lembrar também que o termo utilizado por Jorge Glusberg fazia parte da construção de um programa institucional, no qual procurava legitimar os marcos teóricos e artísticos do CAYC e do grupo de artistas que coordenava. Essa manobra teórica fomentada por Glusberg, que circunscrevia sua produção em uma "metodologia comum" - a arte conceitual praticada nos grandes centros - contudo, caracterizada por sua peculiaridade "que emerge como consequência de uma problemática regional" - acabava por consolidar os esquemas que buscava se distanciar nesse momento. Quer dizer, ao apresentar a diferença da produção local e sua particularidade periférica, terminava por incorporá-las aos circuitos canônicos nos quais a arte argentina circularia nos anos seguintes.

Alguns artistas, inclusive, rejeitaram enfaticamente a categoria "arte conceitual", ao vinculá-la a uma "moda" estrangeira aplicada no âmbito local, mais uma nomenclatura da história da arte que buscava renovar e incentivar a venda de mercadorias. Talvez a mais emblemática seja a obra de Juan Pablo Renzi enviada para a exposição Arte de Sistemas, no Museu de Arte Moderna de Buenos Aires. Tratava-se do terceiro de uma série de panfletos iniciada anos antes e que fazia alusão ao Panfleto no 1, "Tucumán Arde", segundo o próprio artista. O Panfleto $n^{\circ}$ 3: La nueva moda, assinalava criticamente a adoção da arte conceitual, que era vista como uma moda que, entre outras coisas, caracterizava os sistemas da cultura

\footnotetext{
136 "Esta necessidade tem sido sentida em diversos países, sobretudo naqueles onde, por trás de uma primeira apropriação mimética das tautologias e do colonialismo cultural, estas práticas vêm sido submetidas a grandes tensões. Tensões provocadas por contradições sociais peculiares. Neste sentido, Espanha e Argentina são dois exemplos do que um conceitualismo puro consideraria uma versão degenerada dele próprio, em especial se um se detém em suas propostas. Na Argentina tem se falado de um conceitualismo ideológico" (Tradução nossa).
} 
burguesa. Renzi referia-se à menção de Lucy Lippard e do próprio Jorge Glusberg que o situavam como um dos responsáveis pelo início "desse fenômeno" na Argentina. Tratava-se do texto publicado no catálogo da mostra citada anteriormente, 2.972.453, no qual Lippard dissertava sobre as origens e desdobramentos da arte conceitual, inscrevendo em uma possível genealogia, a participação do grupo de artistas envolvidos em Tucumán Arde: "algunos de los primeros trabajos en este campo que llegaron a mi conocimiento, fueron realizados por el grupo Rosario de la Argentina". ${ }^{137}$

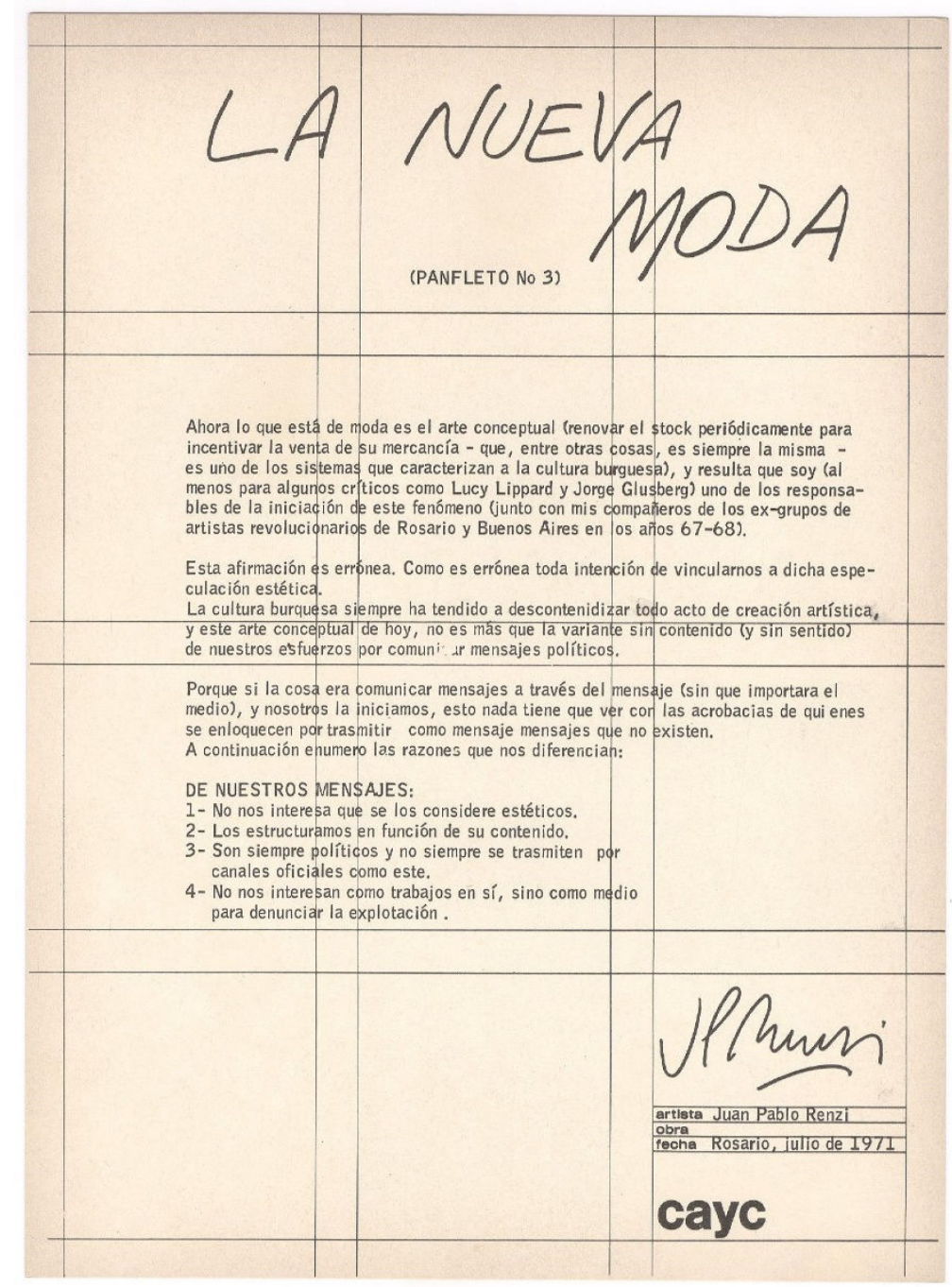

Figura 37 - Obra apresentada na mostra Arte de Sistemas (cat. exp.) Juan Pablo Renzi, 1971

No folder da exposição Anteproyectos, de Horacio Zabala, de 1972, Glusberg procurava traçar uma linha contínua sobre as raízes e o desenrolar das práticas inscritas no

\footnotetext{
137 "alguns dos primeiros trabalhos neste campo que chegaram ao meu conhecimento foram realizados pelo grupo Rosário da Argentina.” (tradução nossa). In: Centro de Arte y Comunicación. 2.872.453, (cat. exp.), Buenos Aires: CAYC, 1970. (09035) Pasta CAYC - Biblioteca Lourival Gomes Machado.
} 
conceitualismo ideológico argentino, voltando-se às vanguardas artísticas da década de 1960, sobretudo ao grupo rosarino e à radicalização política dos artistas ligados ao Di Tella.

Entre los antecedentes del conceptualismo ideológico que desarrolla el Grupo de los Trece, podemos comentar las dos Experiencias Visuales llevadas a cabo en el Instituto Di Tella en 1967 y 1968, la experiencia colectiva 'Tucumán Arde' en 1968, capitaneada por el rosarino Juan Carlos [sic] Renzi [...]la rotura de la imagen de J. Kennedy de Ruano, presentadas en el Museo de Arte Moderno [...]la actitud de Carballa en 'Information', en el Museo de Arte Moderno de Nueva York (GLUSBERG apud DAVIS, 2008) $)^{138}$

A retrospectiva sugerida por Glusberg reunia em um mesmo relato proposições complexas e bastante distintas, apontando para uma ambição maior: validar o Grupo de los Trece, ao introduzir essas práticas precursoras dentro da narrativa do conceitualismo ideológico capitaneado por sua instituição. O que estava em jogo, segundo Davis, era a legitimação do CAYC no campo argentino no início dos anos de 1970: "desde la referencia a las prácticas sesentistas, Glusberg apostaba, de manera implícita, a posicionar al centro porteño en "continuidad" con el interrumpido proyecto de Romero Brest de la anterior década" (DAVIS, 2008) ${ }^{139}$ Para compreendermos as estratégias por trás do relato glusberguiano, é necessário adentrar em duas exposições emblemáticas que fundamentaram o discurso do CAYC nos seus primeiros anos de fundação, demarcaram o direcionamento teórico e consolidaram a postura internacionalista da instituição - Arte de Sistemas $I$ e II, de 1971 e 1972.

\footnotetext{
138 "Entre os antecedentes do conceitualismo ideológico que desenvolve o Grupo de los Trece, podemos comentar sobre as Experiencias Visuales do Instituto Di Tella em 1967 e 1968, a experiência coletiva "Tucumán Arde" em 1968, capitaneada pelo rosarino Juan Carlos [sic] Renzi [...] o rompimento da imagem de J. Kennedy de Ruano, apresentada no Museu de Arte Moderna [...] a atitude de Carballa em Information, no MoMA de Nova Iorque.” (tradução nossa). In: http://www.ramona.org.ar/node/21556. Acesso no dia 07-05-2015

139 "desde a referência às práticas dos anos sessenta, Glusberg apostava, de maneira implícita, em posicionar o centro portenho na "continuidade" do projeto interrompido de Romero Brest na década anterior." (tradução nossa). Ibidem.
} 


\subsection{1 - DA ARTE DE SISTEMAS AL AIRE LIBRE}

A exposição Arte de Sistemas foi inaugurada no Museu de Arte Moderna de Buenos Aires, em julho de 1971. Fez parte de uma ampla convocatória de 101 artistas nacionais e estrangeiros, entre eles vários integrantes do Grupo de los Trece (que seria fundado alguns meses depois) e contemporâneos como Vito Acconci, John Baldessari, Christo, Allan Kaprow, Joseph Kosuth, Richard Long, Mario Merz, Nam June Paik, Richard Serra, Hans Haacke etc. Estavam presentes, também, o colombiano Bernardo Salcedo e o peruano Rafael Hastings. A participação de nomes destacados da cena internacional dava maior visibilidade e legitimava o nome da instituição, outorgando ao CAYC a importância de conceber exposições com propostas semelhantes, como Information, realizada um ano antes no MoMA de Nova Iorque. Com curadoria de Kynaston McShine, essa mostra reuniu cerca de 150 artistas da Europa, EUA, América Latina e de países comunistas, representando os mais significativos movimentos artísticos do momento como arte conceitual, arte povera, earthworks, arte processual e videoarte. Certamente Information foi uma grande referência para o crítico argentino, pois sabemos que Glusberg acompanhava o trabalho de McShine desde a década anterior. Primary Structures, no Jewiesh Museum de Nova Iorque, em 1966, preparada pelo curador norte-americano, havia sido modelo de uma exposição organizada por Glusberg em 1967, intitulada Estructuras Primarias II, na Sociedade Hebraica de Buenos Aires. O correlato argentino do minimalismo era uma homenagem à mostra novaiorquina e já evidenciava a preocupação precoce de Glusberg por validar as práticas locais ao conectá-las aos movimentos internacionais. Vale citar que muitos artistas que participaram de Information estavam presentes em Artes de Sistemas.

Para alcançar um número elevado de participantes estrangeiros, Arte de Sistemas elegeu o papel heliográfico como canal privilegiado. Contudo, os objetos não desapareceram do dispositivo expositivo validado por Glusberg, embora muitas vezes fossem substituídos por sua documentação, de modo a simplificar a sua circulação. Como vimos, a categoria arte de sistemas se referia a "procesos más que a produtos terminados del 'buen arte"”. E por meio da mostra, tratariam de intensificar a compreensão acerca desses sistemas "conduciendo al espectador a través de los problemas principales que conciernen a las experiencias que se dan en este ultimo tercio del siglo XX" (GLUSBERG, 1971). ${ }^{140}$

140 "processos mais que a produtos terminados da "boa arte." [...] "Conduzindo o espectador por meio dos principais problemas que concernem as experiências que se dão neste último terço do século XX ." (tradução nossa). 


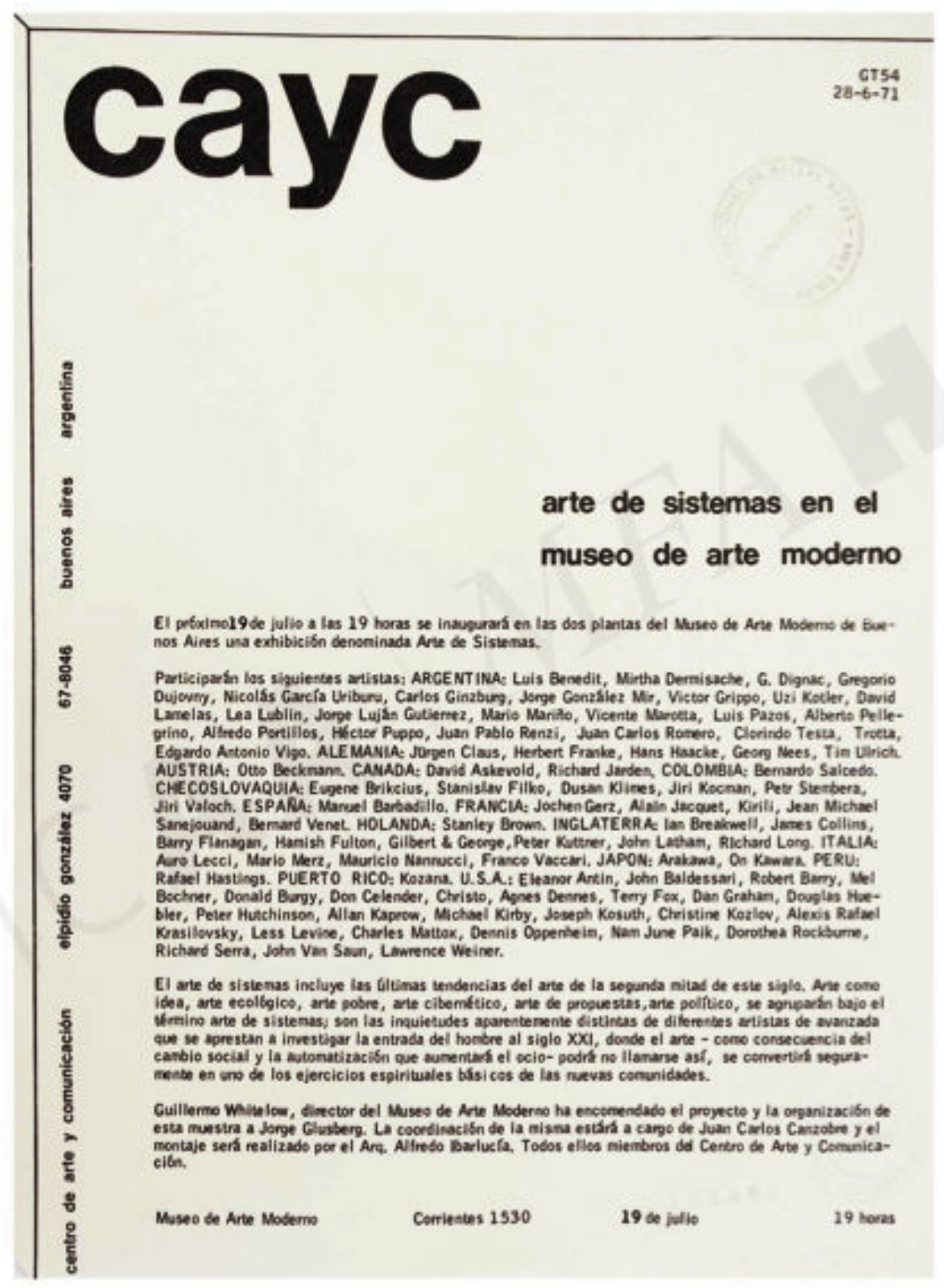

Figura 38 - Arte de Sistemas en el Museo de Arte Moderno Gacetilla GT 54. 28-06-1971

ICCA - Documents of 20th-Century Latin American and Latino Art.

O pronunciamento do diretor do MAM de Buenos Aires, Guillermo Whitelow, na ocasião da inauguração da mostra, evidenciava a importância da renovação artística capitaneada pela proposta interdisciplinar do CAYC, com a inclusão da ciência, da matemática e a aproximação com outras tantas matrizes teóricas como pressuposto institucional. Sugeria aos espectadores que ao visitarem a exposição, adotassem outra postura, pois "nos hallamos en un campo que no se puede medir con antiguos cánones". E completava o seu discurso: 
Ante todo, nos encontramos aquí con un vasto gesto informativo que, desde lo conceptual a lo cibernético, no apela a un contemplador en busca de sublimaciones estéticas sino a un testigo lúcido de problemas contemporáneos y de investigaciones que tienen mucho que ver con la metodologia. ${ }^{141}$

Dos exemplos locais de Arte de Sistemas, podemos destacar a obra Tierra (1971), de Carlos Ginzburg. Se apropriando das estratégias de earthwork, o artista argentino utilizava ao mesmo tempo recursos naturais e estratégias publicitárias para realizar uma crítica institucional. Dois outdoors na rua do MAM instigavam os transeuntes com a pergunta "¿Que hay dentro de este terreno?", e os convidava para viver "una inesperada experiencia estética" e "descobrir un trabajo escondido". Diversas sinalizações dentro do Museu conduziam o espectador até a janela do nono andar onde se podia ver o trabalho de Ginzburg: a palavra "tierra" escrita no terreno baldio ao lado da instituição. A obra ganhava diversos sentidos, desde a apropriação de uma parcela de terra como metáfora da propriedade privada do sistema capitalista (HERRERA, 2013), como, também, crítica implícita ao circuito tradicional artístico. $\mathrm{O}$ artista tomava emprestado o espaço do museu para expor a obra Tierra fora de seu ambiente.

\footnotetext{
141 “Achamos-nos em um campo que não se pode medir com antigos cânones.” [...]. "Ante tudo, nos encontramos aqui com um vasto gesto informativo que, desde o conceitual ao cibernético, não apela a um contemplador em busca de sublimações estéticas, mas a um testemunho lúcido de problemas contemporâneos e de investigações que muito tem a ver com a metodologia." (Tradução nossa). In: ICCA - Documents of 20thCentury Latin American and Latino Art.
} 


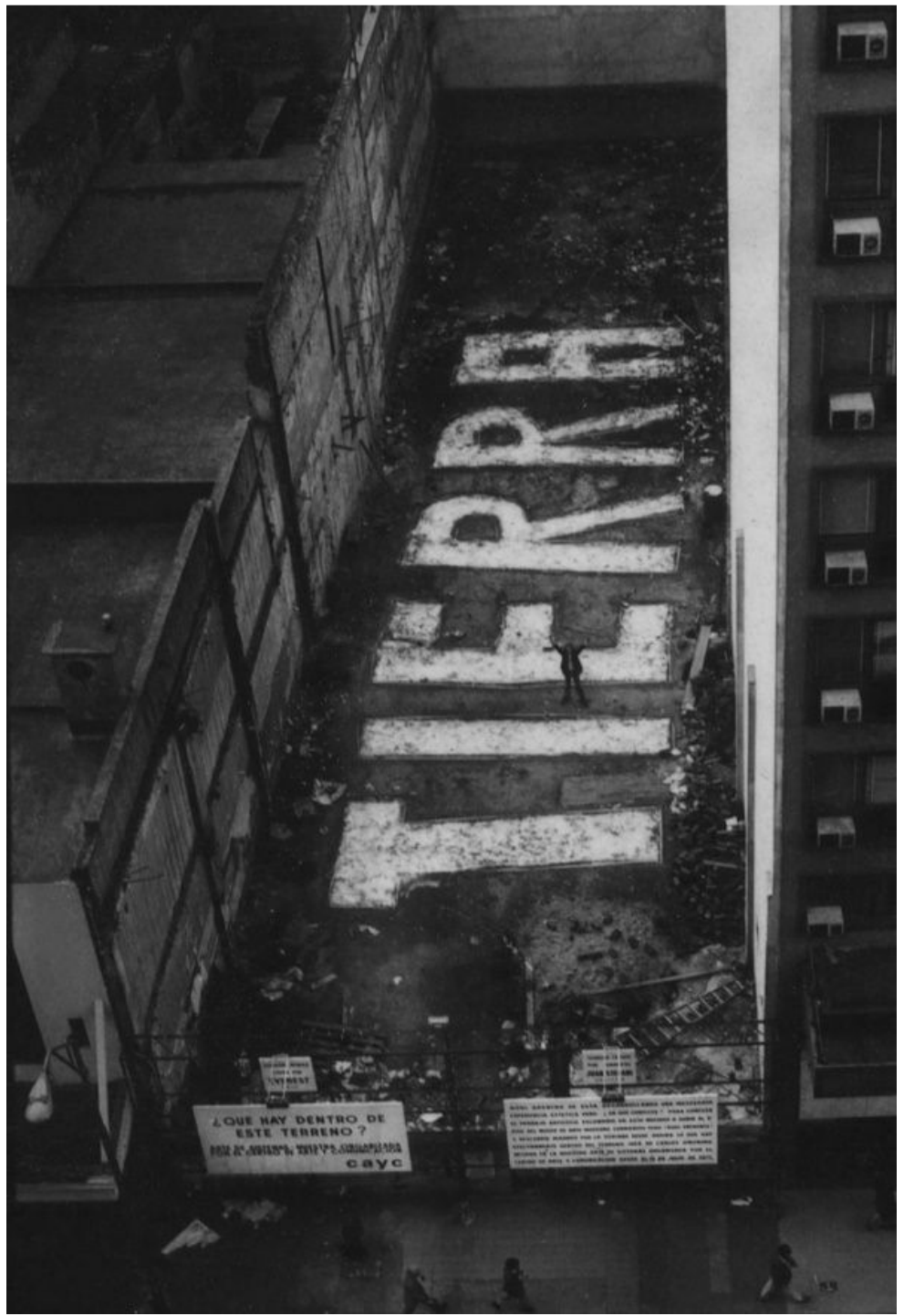

Figura 39 - Tierra, Carlos Ginzburg Arte de Sistemas, 1971

Por sua vez, Luis Pazos, Héctor Puppo e Jorge Gutiérrez, seguindo a linha crítica iniciada na década anterior pelos artistas da arte de los medios, realizaram uma falsa notícia: o sequestro de Jorge Glusberg. Usando a linguagem jornalística, montaram uma sequência de falsos recortes por meio da simulação de recursos gráficos dos jornais impressos. O jornal informava que o crítico do CAYC havia sido raptado no dia anterior por um grupo de artistas identificados como G.E.E. (Grupo de Experiencias Estéticas) que exigiam que "los medios artísticos nos eschuchen seriamente nuestros reclamos". Por meio do humor, os artistas faziam uso de situações conflitantes de ordem sócio-política, inserindo-as no campo artístico. $^{142}$

142 SARTI, Graciela. Grupo CAyC, Buenos Aires, Centro Virtual de Arte Argentino. Disponível em: http://cvaa.com.ar/02dossiers/cayc/04_histo_01.php. Acesso em 27 jun. 2015. 


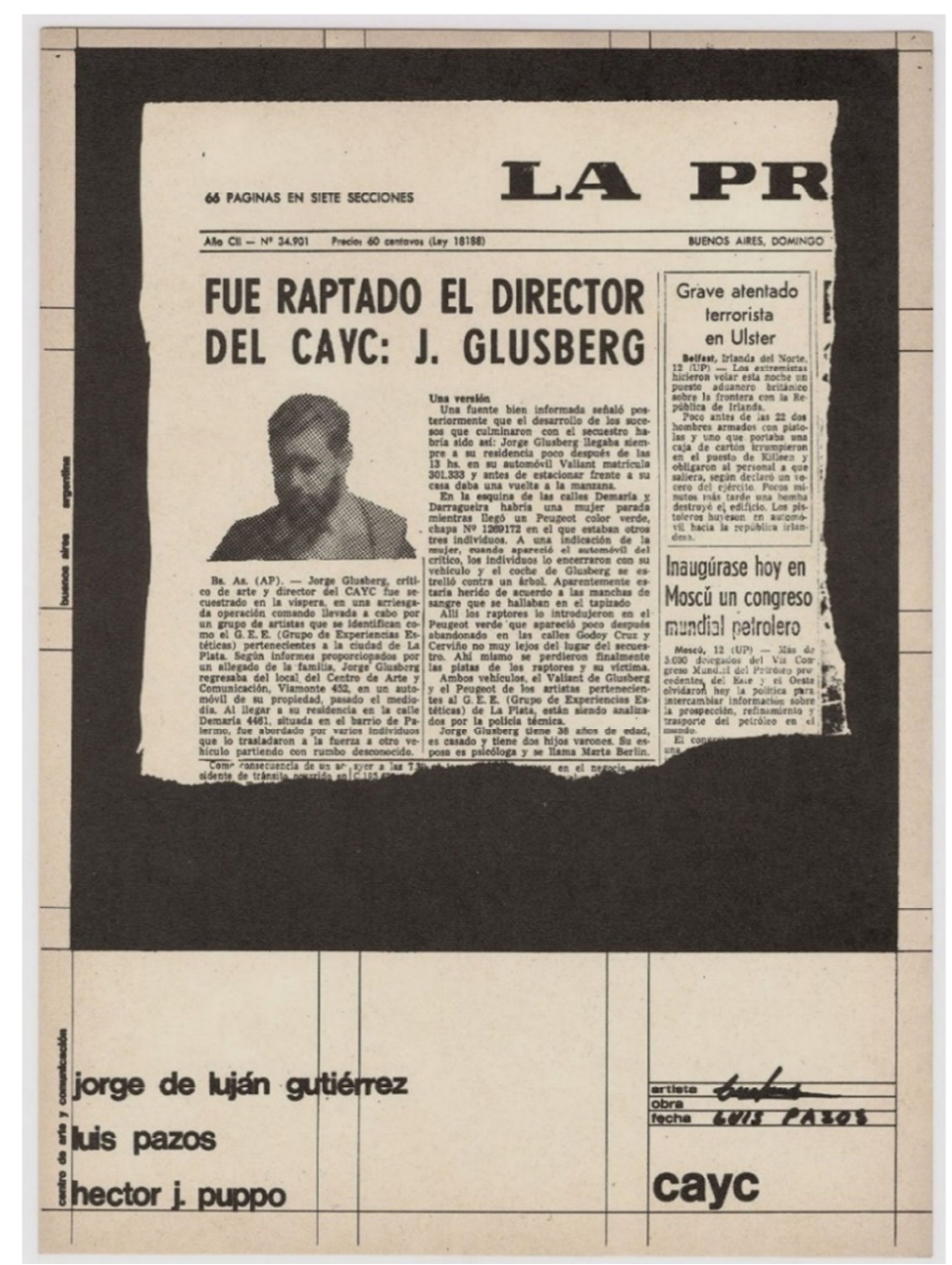

Figura 40 - Obra apresentada na mostra Arte de Sistemas (cat. exp.) Jorge Gutiérrez, Luis Pazos, Hector Puppo, 1971

Nesse momento, o CAYC sustentava as categorias arte de sistemas e arte conceitual como modalidades artísticas e como parte de sua agenda institucional, tendo em vista os estudos interdisciplinares como ponto de apoio. Embora o discurso político e regional ainda não fizesse parte estruturante do programa institucional, algumas obras de Arte de Sistemas faziam menção direta ou indiretamente às demandas políticas da época. É o caso de uma das propostas enviadas por Luis Pazos, Héctor Puppo e Jorge Gutiérrez, que faziam uma crítica implícita, carregada de humor e ironia, às Forças Armadas, que desde o golpe de 1966, ascendiam politicamente no país. La Cultura de la Felicidad consistia na distribuição de máscaras de papel com um sorriso estampado e um texto curto em que dizia que era obrigatório ser feliz na Argentina e seguir fielmente o Triunvirato: "1- amarás al Triunvirato sobre todas las cosas y a cada uno de los miembros como a tí mismo. 2- No tomarás el 
nombre del Triunvirato en vano. 3- Santificarás sus fiestas y días de guarda etc"143. Sobre essa ação, Luis Pazos falou:

Distribuí máscaras com um sorriso e escrevi um texto que dizia que era obrigatório ser feliz na Argentina, senão iriam presos. E as pessoas colocavam a máscara e ficavam felizes! Era uma metáfora sobre a ditadura que já estava lá. [...] Já se podia vislumbrar o que ia se passar na Argentina. [...] Estávamos na beira do abismo, e caímos no abismo. ${ }^{144}$

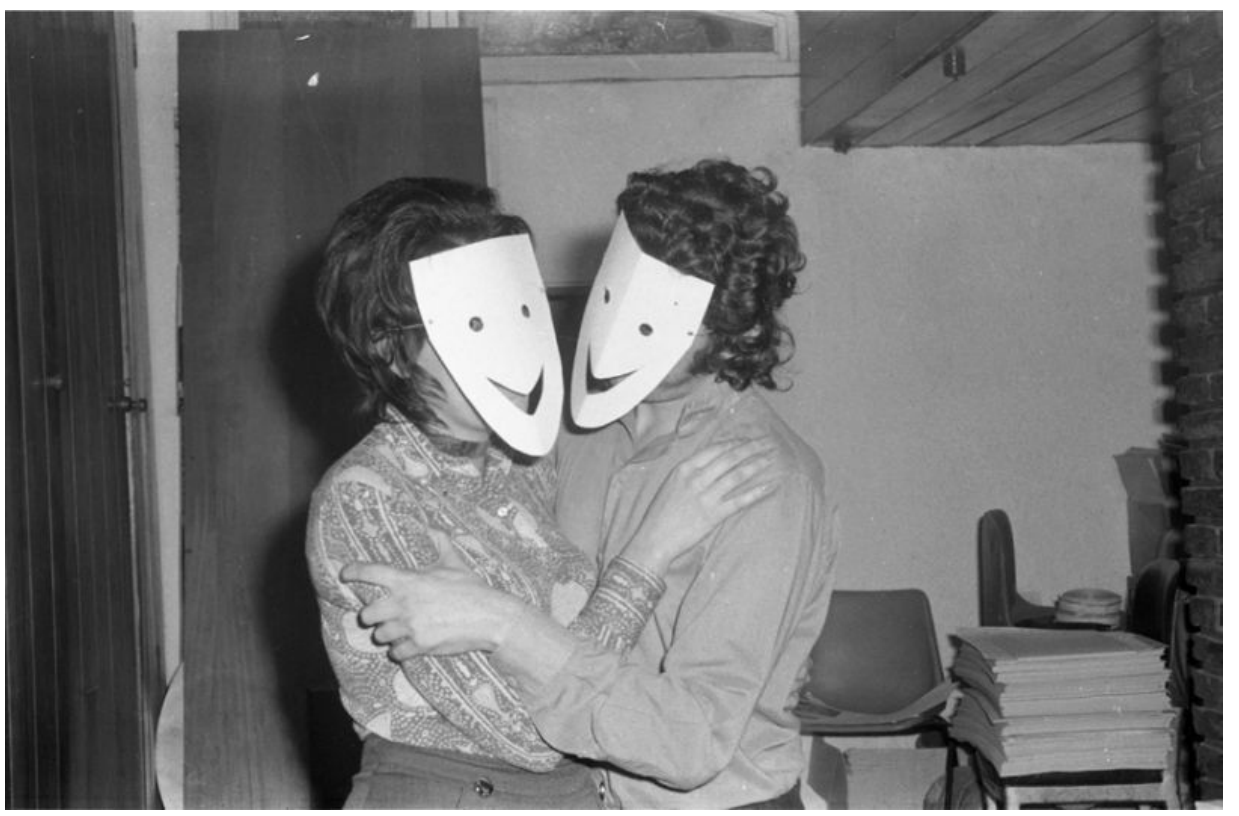

Figura 41 - La cultura de la felicidad Jorge Gutiérrez, Luis Pazos, Hector Puppo. Fotografia P\&B, 30 x 40 cm, 1971

$\mathrm{O}$ artista argentino Vicente Marotta propôs um projeto de computadores eletrônicos como forma de democratizar e ampliar as votações e a consulta direta à população. Essa grande revolução de caráter "ideológico, político, económico y tecnológico", visava aumentar o acesso aos recursos eletrônicos para que a população pudesse decidir o "seu destino", substituindo as formas ultrapassadas de governo e participação. A proposta intitulada Una República Democrática, buscava instalar emissores em praças, centros cívicos e povoados

\footnotetext{
143 “Amarás o Triunvirato sobre toda as coisas e a cada um dos membros como a si mesmo. Não tomarás o nome do Triunvirato em vão. Santificarás suas festas e dias de resguardo etc." (tradução nossa). In: Experiencias, Buenos Aires: CAYC, 1971, p. 47-48.

144 Entrevista concedida à Cristina Freire, em 2008, na Argentina. In: FREIRE, Cristina. (Org.). Terra incógnita. Conceitualismos da América Latina no acervo do MAC USP. São Paulo: Museu de Arte Contemporânea da Universidade de São Paulo, 2015, p. 99.
} 
rurais "sin permitir desigualdades basadas en lo económico-social" (MAROTTA, 1971, cat.exp.). ${ }^{145}$

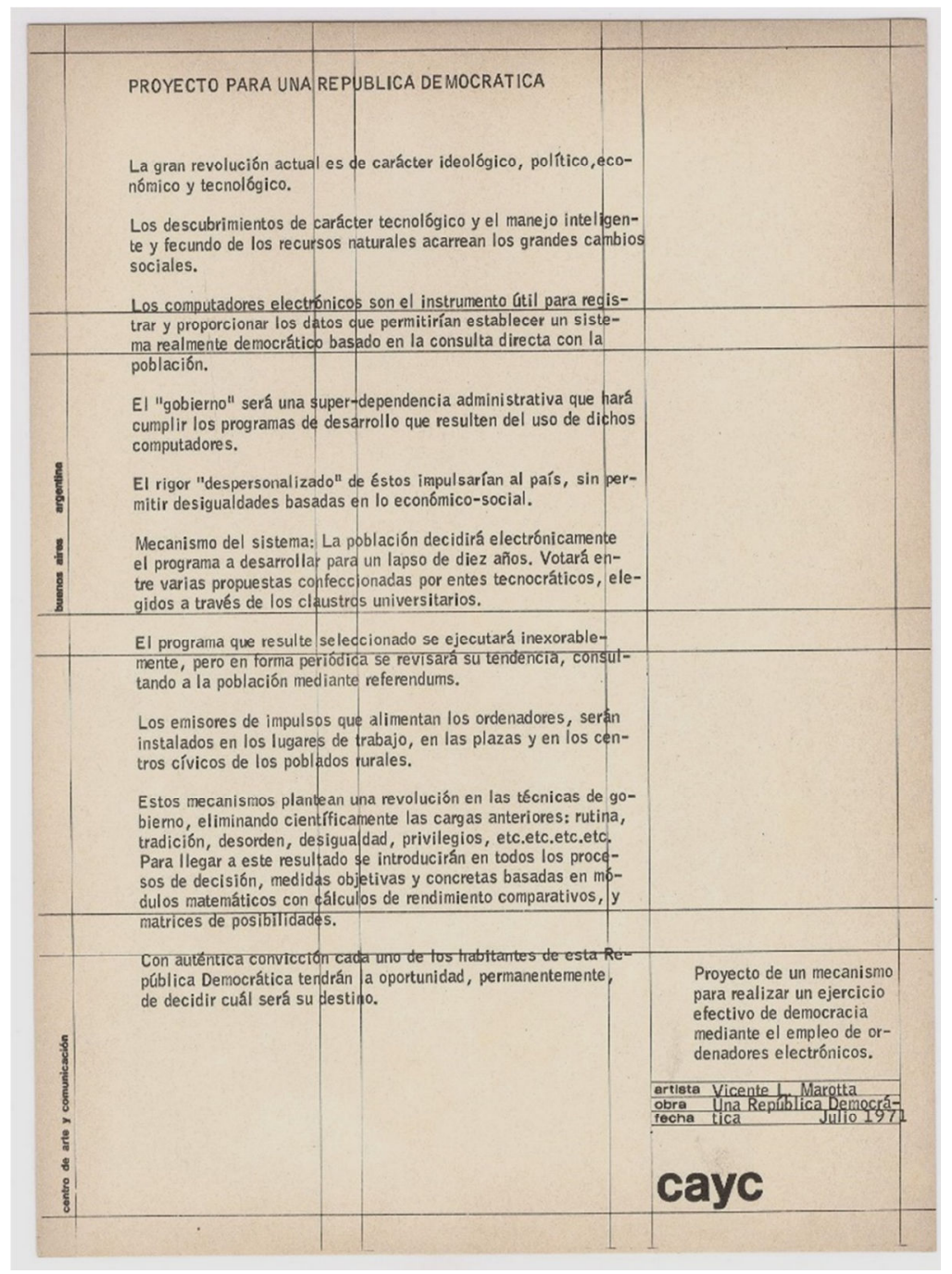

Figura 42 - Obra apresentada na mostra Arte de Sistemas (cat. exp.) Vicente Marotta, 1971

Do político ao ecológico, da informação às novas tecnologias, a ambiciosa mostra de Glusberg passava pelas mais diversas expressões e problematizações da arte contemporânea, inserindo a produção local no mesmo pé de igualdade dos artistas internacionais convidados. Sabemos por meio da matéria divulgada no jornal Análisis, de Buenos Aires, como foi uma parte da recepção crítica da exposição. O "grande show" da arte de sistemas trazia as últimas tendências ao público com inumeráveis elementos para entreter e escandalizar. O jornal noticiava a tentativa frustrada do projeto inicial de Glusberg, que era enviar a mostra Arte de

145 “ideológico, político, econômico y tecnológico" [...] "sem permitir desigualdades baseadas no econômicosocial” (tradução nossa). 
Sistemas para a Bienal de São Paulo. Diante da abstenção e recusa de diversos artistas que aderiram ao boicote organizado na mesma época, o diretor do CAYC desistiu de seu propósito e "aprovechó el material ya acumulado para mostrarlo en Buenos Aires donde la sensibilidade político-artística parece no encontrar obstáculos". ${ }^{146}$ A matéria passava rapidamente por algumas obras expostas, evidenciando a dificuldade de compreensão da mostra, que pressupunha um público especializado.

La misma insensatez caracteriza a la mayoría de los participantes de la muestra. Ciertos artistas que en su mayoría apenas estaban capacitados para el manejo de certa habilidade manual y el desarrollo de algunas ideas relativas a problemas plásticos, ahora se ven obligados a entrar generalmente más mediante los músculos que por el uso de la cabeza - en el mundo de los conceptos filosóficos, científicos y sociológicos. ${ }^{147}$

Essa exposição foi uma espécie de pedra fundamental da proposta internacionalista de Glusberg, trazendo um grande número de artistas estrangeiros para o país ao mesmo tempo em que promovia a arte local. No final de 1971, vimos que o diretor do CAYC formou o Grupo de los Trece, dando sequência às ideias iniciais promovidas em Arte de Sistemas. Contudo, esse grupo de artistas operaria a partir de uma produção ideológica e regionalista que evidenciasse os problemas sociais. No ano seguinte, Glusberg organizou a mostra Arte de Sistemas II, dividida em três sessões: Arte de Sistemas Internacional, no MAM; Arte de Sistemas Argentina, nas salas do CAYC; e Arte e Ideología. CAYC al Aire Libre, na praça Roberto Arlt. A programação das exposições e o catálogo de Arte e Ideología ... circularam em uma bolsa de polietileno impressa na frente e no verso com desenhos do artista alemão Joseph Beuys, um dos participantes da mostra do MAM. Comparación entre dos tipos de sociedades e La forma de destruir la ditadura de los partidos, eram parte do projeto Organización para la Democracia Directa a través del Plebiscito que procurava garantir um sistema de informação livre de censura e controle, por meio da quebra dos monopólios partidários.

A exposição buscava validar a ideia de conceitualismo ideológico, proposto por Glusberg, catalisando o sentido de "problemática nacional" ao promover as obras na rua. Ou

\footnotetext{
146،aproveitou o material já acumulado para mostrá-lo em Buenos Aires, onde a sensibilidade político-artística parece não encontrar obstáculos." (Tradução nossa). In: El bazar de sistemas. Análisis. N. 541, julho 1971. ICCA - Documents of 20th-Century Latin American and Latino Art. Registro: 747124.

147 "A mesma insensatez caracteriza a maioria dos participantes da mostra. Certos artistas, que em sua maioria apenas estavam capacitados para o manejo de certa habilidade manual e o desenvolvimento de algumas ideias relativas aos problemas plásticos, agora se veem obrigados a entrar - mais pelos músculos do que pelo uso da cabeça - no mundo dos conceitos filosóficos, científicos e sociológicos." (Tradução nossa). In: El bazar de sistemas. Análisis. N. 541, julho 1971. ICCA - Documents of 20th-Century Latin American and Latino Art. Registro: 7471244.
} 
seja, um lugar de convivência dos "transeúntes, parejas que hacen el amor, grupos de estudiantes, niños que juegan en la plaza", distantes dos "ámbitos elitistas de Museos y Galerías" (GLUSBERG, 1972, cat.exp.) ${ }^{148}$. Entretanto, esse espaço aberto de trocas e convívio pacífico simbolizado pela rua e descrito no catálogo não estava de acordo com a realidade marcada pelo crescente conflito protagonizado pelas forças policiais e militares, os setores populares e as organizações armadas. Arte e Ideología. CAYC al Aire Libre durou apenas 48 horas, quando foi censurada e destruída pela polícia. A convulsionada situação política argentina e a possibilidade de uma arte de transformação social se debatiam em diálogo com o espaço público (HERRERA, 2013, p. 36). Parte das obras expostas fazia menção ao recente massacre de Trelew, em que dezesseis prisioneiros políticos de grupos guerrilheiros foram fuzilados depois de uma tentativa de fuga. Nesse contexto, a arte exposta na rua concentrava diversas tensões sócio-políticas de um território em constante disputa. A problematização da rua ia muito além das representações utópicas de ampliação e aproximação da arte com o público, em um momento em que se apropriar da rua significava subverter a sua ordem diante de um crescente imperativo revolucionário, de acordo com Davis (2012, p.8).

La realidade subterránea, de Luis Pazos, Roberto Duarte, Eduardo Leonetti e Ricardo Roux, foi concebida durante a montagem da exposição e consistia em 16 cruzes enfileiradas e pintadas de cal ao lado de fotografias de campos de concentração nazista. A analogia entre o massacre de Trelew e os campos de extermínio alemães representava a turbulência da realidade violenta e a institucionalização da tortura e do assassinato da sociedade civil. $\mathrm{O}$ teórico alemão Andreas Huyssen nos lembra que a menção ao Holocausto e todo o tipo de discurso sobre a memória e as histórias traumáticas tornaram-se transnacionais, migrando para contextos políticos não relacionados necessariamente com eles (2014, p.12). Os tropos discursivos e as iconografias ligadas ao Holocausto emergiram em diversos contextos de ditadura e regimes de exceção, como podemos observar na analogia perturbadora de $L a$ realidade subterránea. Outra obra que fazia alusão a Trelew era 300 metros de cinta negra para enlutar una plaza pública, de Horacio Zabala. O artista cercou a área da praça com um plástico preto que era interrompido a distâncias regulares por crepes funerários, como forma de homenagear as vítimas.

\footnotetext{
148 "Transeuntes, casais que fazem amor, grupos de estudantes e crianças que brincam na praça. Âmbitos elitistas de Museus e Galerias." (tradução nossa).
} 


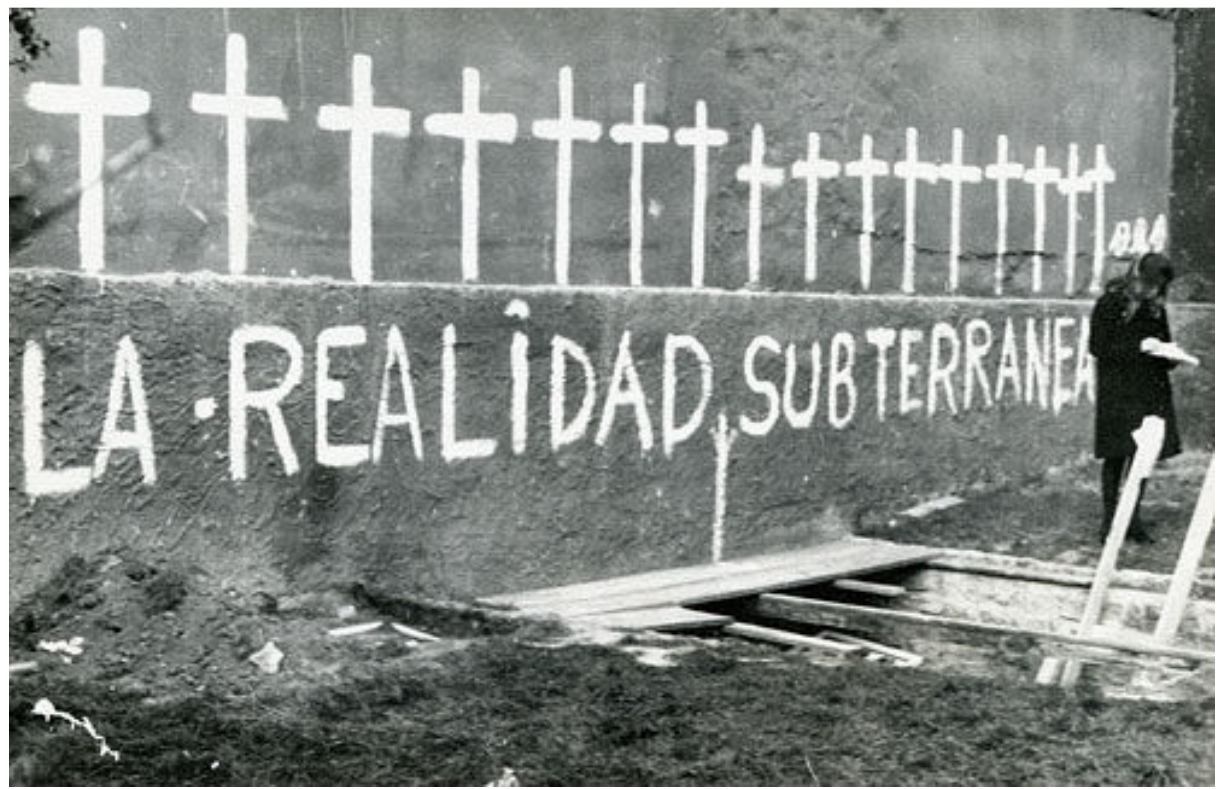

Figura 43 - La realidade subterranea

Luis Pazos, Roberto Duarte, Eduardo Leonetti e Ricardo Roux , 1972

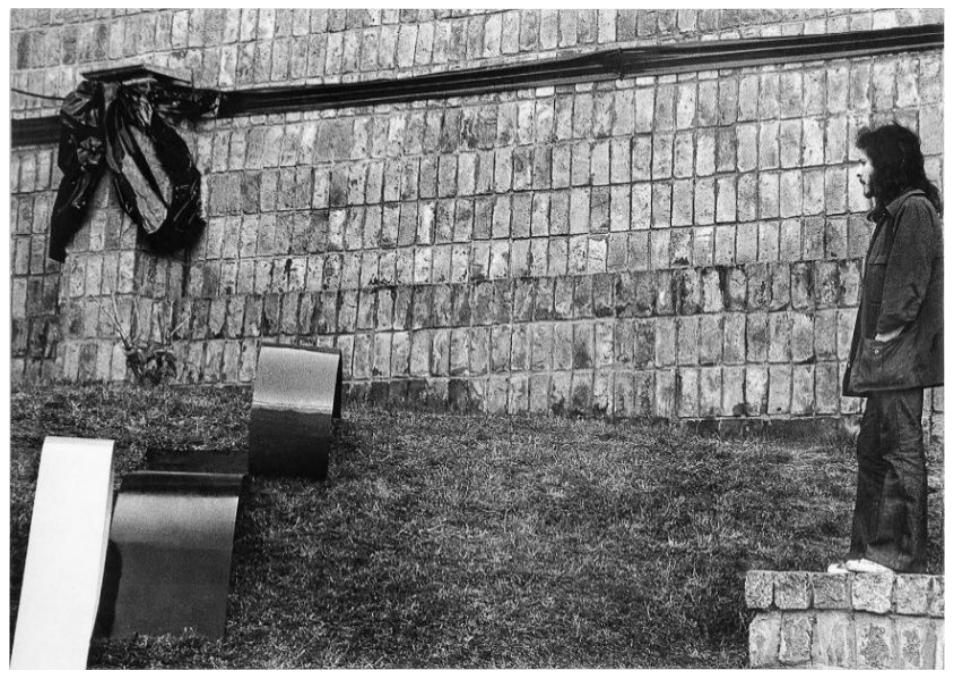

Figura 44 - $\mathbf{3 0 0}$ metros de cinta negra para enlutar una plaza pública Horacio Zabala, 1972

O problema da desigualdade social e da fome foi tema de duas obras: Proyecto de solución para el problema del hambre em los países subdesarrollados, no qual Julio Teich propunha a construção de uma horta natural no centro de Buenos Aires; e Construcción de un horno popular para hacer pan, de Jorge Gamarra e Victor Grippo. Em ambos os casos, os saberes das culturas tradicionais e do fazer artesanal como alternativas sociais colidiam com a racionalidade técnica da cultura capitalista. Gamarra e Grippo fizeram um forno de barro com a ajuda de um trabalhador rural e ao longo dos dois dias de exposição, distribuíram pães aos transeuntes. 


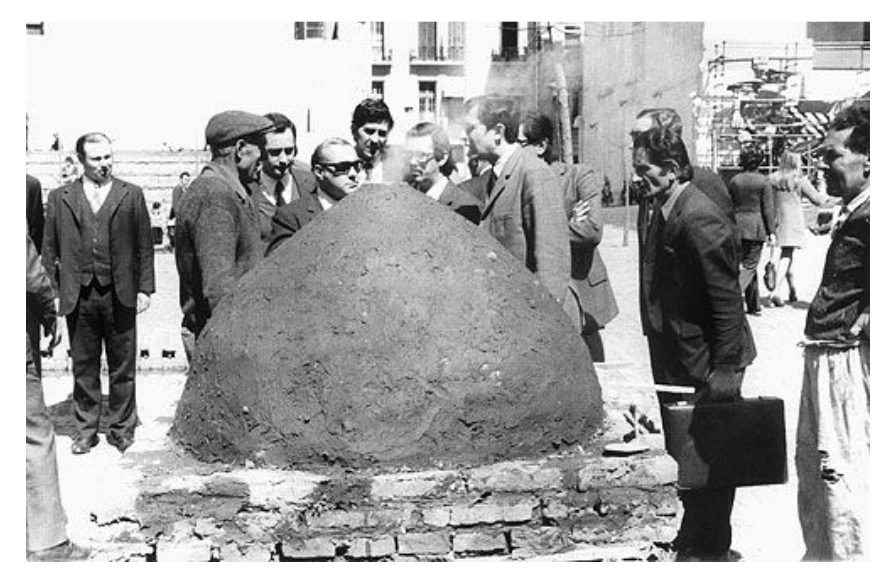

Figura 45 - Construcción de un horno popular para hacer pan Victor Grippo e Jorge Gamarra, 1972

Um funcionário municipal denunciou a exposição por seu conteúdo político e logo depois as forças policiais chegaram na praça para desmontar e confiscar todas as obras exibidas. As autoridades municipais que fecharam a mostra justificaram tal medida "en la apreciación de que la expresión de arte se había desvirtuado, dándosele carácter subversivo", de acordo com uma matéria publicada no jornal Clarín. ${ }^{149}$ Um comunicado emitido apontava que o argumento para a censura se baseava na incompreensão artística policial, pois "no ha sido expuesto lo que nosotros tenemos indefinidamente dado como arte", de acordo com a nota oficial. Glusberg organizou uma ofensiva campanha de apoio, com repercussão internacional, solicitando a revisão "de la medida y para que los artistas argentinos se puedan expresar libremente a través de sus obras". ${ }^{150}$ Diversos artistas se manifestaram contra a clausura da exposição, entre eles Dick Higgins, John Baldessari, Allan Kaprow, Jaroslaw Kozlowski etc. Glusberg reuniu todas as mensagens de apoio e as emitiu em comunicados de imprensa e em forma de cartas destinadas ao presidente Alejandro Augustín Lanusse. Dick Higgins, um dos expoentes do Fluxus, escrevera:

El mejor arte es siempre un poco molesto, especialmente cuando está inmaduro y aún vivo, y por su edad no está aún colocado en un pedestal. [...]

\footnotetext{
149 "Na apreciação de que a expressão de arte havia se desvirtuado, dando caráter subversivo.” (tradução nossa). In: Arte y política: el levantamiento de una muestra plástica tuvo fundamento legal. Clarín. Buenos Aires. 8 de dezembro de 1972. ICCA - Documents of 20th-Century Latin American and Latino Art. Registro: 747956 150 "Não foi exposto o que nós temos dado indefinidamente como arte." [...] da medida e para que os artistas argentinos possam expressar-se livremente por meio de suas obras." (tradução nossa). In: Comunicado $\mathbf{n}^{\mathbf{0}} \mathbf{2}$ : Clausura de la muestra CAYC al Aire Libre en la plaza Roberto Arlt. 14 de dezembro de 1972. ICCA Documents of 20th-Century Latin American and Latino Art. Registro: 747531
} 
la Argentina no ha sido conocida por sus artes de vanguardia, muy poco hubo relevancia internacional, antes de Jorge Glusberg y su CAYC. ${ }^{151}$

A experiência proposta em Arte e Ideología. CAYC al Aire Libre nos faz recordar de outra exibição emblemática dentro do contexto brasileiro, que também fora organizada ao ar livre. Do corpo à terra, de 1970, com curadoria do crítico e historiador da arte Frederico Morais, foi uma manifestação artística que se desenvolveu no Parque Municipal de Belo Horizonte, durante cinco dias. Fazia parte de outro evento simultâneo, intitulado Objeto $e$ Participação $^{152}$, no Palácio das Artes. Morais escreve que fora convidado na ocasião para organizar um salão de escultura e que, no entanto, resolvera trocar essa modalidade tradicional pelo objeto, que era tema de discussão desde a década anterior. Nesse sentido, o objeto era "como uma situação nova, que configura ou é o veículo mais adequado para expressar as novas realidades propostas pela arte pós-moderna" (MORAIS, 2004, p. 116). Para a manifestação no Parque Municipal, diversos artistas foram convidados para criarem trabalhos de caráter efêmero diretamente no local, entre eles Cildo Meireles, Artur Barrio e Hélio Oiticica. Foi distribuído pela imprensa mineira e carioca um texto mimeografado pelo crítico - Manifesto Do Corpo à terra - em que argumentava de modo contundente que a arte "é na verdade o exercício experimental da liberdade", propositora de "situações, eventos, rituais ou celebrações", uma necessidade social que tem por "objetivo ativar todos os sentidos do homem". E prosseguia sugerindo uma "simples apropriação de objetos, de áreas urbanas e suburbanas, geográficas ou continentais".

Essa manifestação foi proposta logo após o regime militar brasileiro instalar o Ato Institucional $\mathrm{n}^{\mathrm{o}} 5$, período de embrutecimento da repressão organizada pelo Estado, da suspensão dos direitos civis, da censura dos meios de comunicação e da oficialização da tortura. O AI-5 constituiu-se como marco na produção das artes plásticas brasileira, provocando, entre outras situações, o boicote nacional e internacional à Bienal de São Paulo, uma forma de "guerrilha artística" que buscava desarticular o sistema vigente da arte

151 "A melhor arte é sempre um pouco incômoda, especialmente quando está precoce e ainda viva, e por sua idade ainda não está colocada em um pedestal. A Argentina não tem sido reconhecida por suas artes de vanguarda, e teve pouca relevância internacional antes de Jorge Glusberg e seu CAYC." (tradução nossa). In: Comunicado $\mathbf{n}^{\circ}$ 4: Duplicados de telegramas y cartas recibidas a raíz de la clausura de CAYC al Aire Libre, dirigidas al Excelentísimo Señor Presidente General Alejandro Agustín Lanusse. ICCA - Documents of 20thCentury Latin American and Latino Art. Registro: 747542

${ }^{152}$ Participaram dos dois eventos os artistas Alfredo José Fontes, Artur Barrio, Carlos Vergara, Cildo Meireles, Décio Noviello, Dileny Campos, Dilton Araújo, Eduardo Ângelo, Franz Weissman, George Helt, Lee Jaff (representando Hélio Oiticica), Ione Saldanha, José Ronaldo Lima, Lotus Lobo, Luciano Gusmão, Luiz Alfhonsus, Manoel Serpa, Manfredo de Souzanetto, Orlando Castaño, Yvone Etrusco, Teresinha Soares, Thereza Simões, Umberto Costa Barros e Frederico Morais. 
(MORAIS, 2004, p. 119). O crítico havia usado o termo "artista-guerrilheiro" para designar a tarefa artística como uma forma de "criar para o espectador [...] situações nebulosas, incomuns, indefinidas, provocando nele, mais que o estranhamento ou a repulsa, o medo" e finalizava atestando que a "contestação da arte afluente deve ser, sobretudo, tarefa do terceiro mundo, da América Latina, de países como o nosso" (MORAIS, 1975, p. 26-34). ${ }^{153}$ A comparação do artista com um guerrilheiro situava-se em um momento caracterizado pela radicalização artística e tinha como correlato a marca da luta armada conduzida pelas guerrilhas urbanas. E como vimos anteriormente em "Uma problemática própria", os artistas brasileiros também trabalharam com a precariedade assumida como estratégia artística, em sintonia com a realidade econômica dos países subdesenvolvidos. Artur Barrio, por exemplo, lançou no Ribeirão do Arrudas as "trouxas ensanguentadas", atraindo a atenção de muitos transeuntes e criando um ambiente de tensão que causou a intervenção do Corpo de Bombeiros e da polícia. Situações $T / T$ se evidenciava por sua natureza efêmera e se decompôs ao longo dos dias. Os restos de ossos, espumas e pedaços de carne ensanguentados faziam uma alusão explícita às torturas e mortes deliberadas pelo regime militar.

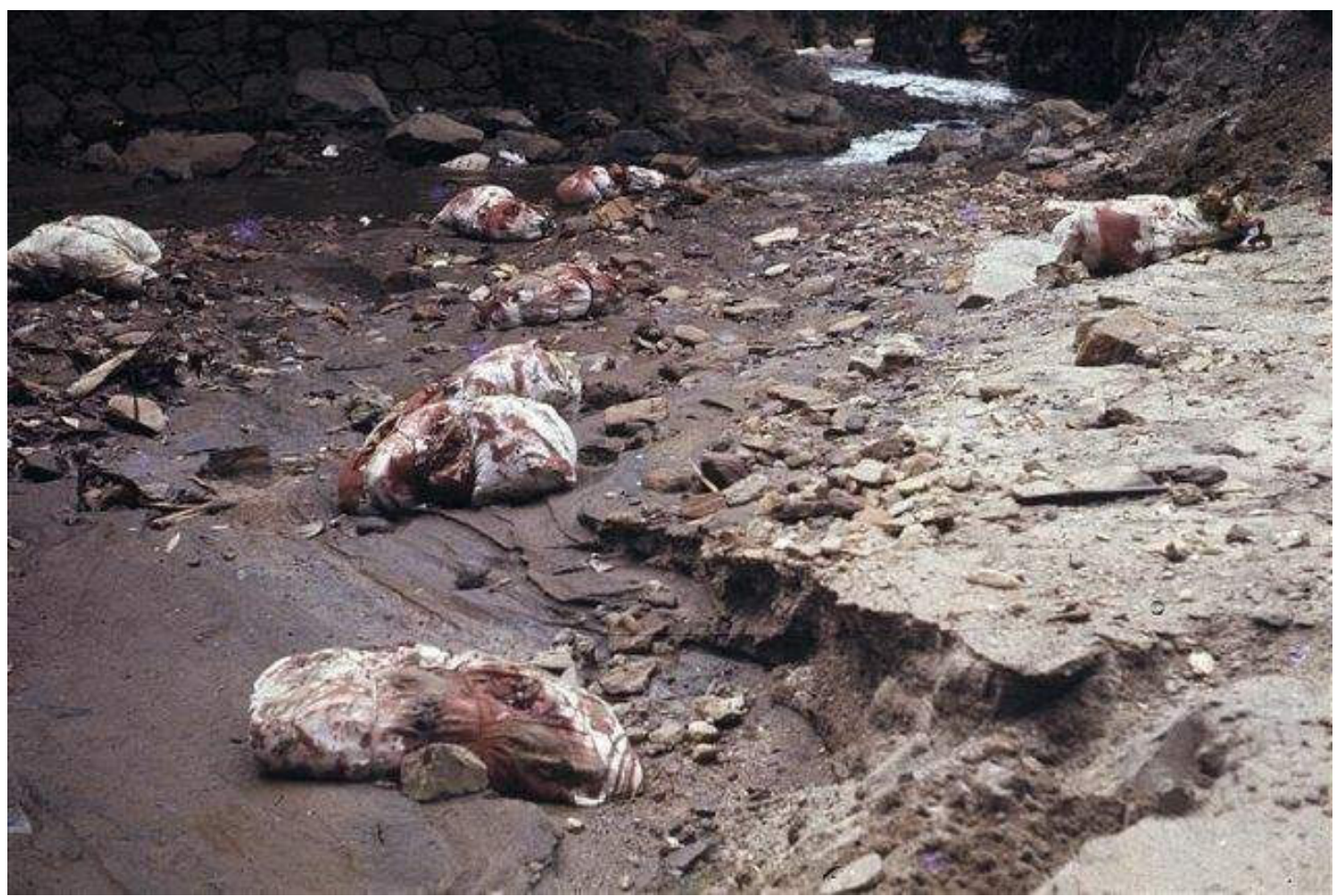

Figura 46 - Situações T/T, Artur Barrio

Trouxas de pano, ossos, carne, sangue, barro, espuma de borracha, cordas, 1970.

153 Texto originalmente publicado em 1970, alguns meses antes da abertura da manifestação Do corpo à terra. In: MORAIS, Frederico. Contra o corpo afluente: o corpo é o motor da "obra". Revista Cultura Vozes, Rio de Janeiro, v. 1, n. 64, jan. - fev. 1970. 
Por sua vez, Cildo Meireles realizou uma das ações mais violentas e críticas da época: Tiradentes: Totem-monumento ao preso político. Como o evento organizado por Morais fazia parte de uma série de comemorações oficiais relacionadas à Inconfidência Mineira, Meireles buscava fazer uma crítica ferrenha à apropriação da imagem heroica de Tiradentes feita pela ditadura militar. $\mathrm{O}$ artista amarrou dez galinhas vivas em uma estaca de madeira e ateou fogo, criando um ritual de sacrifício que simbolizava os assassinatos de prisioneiros políticos.

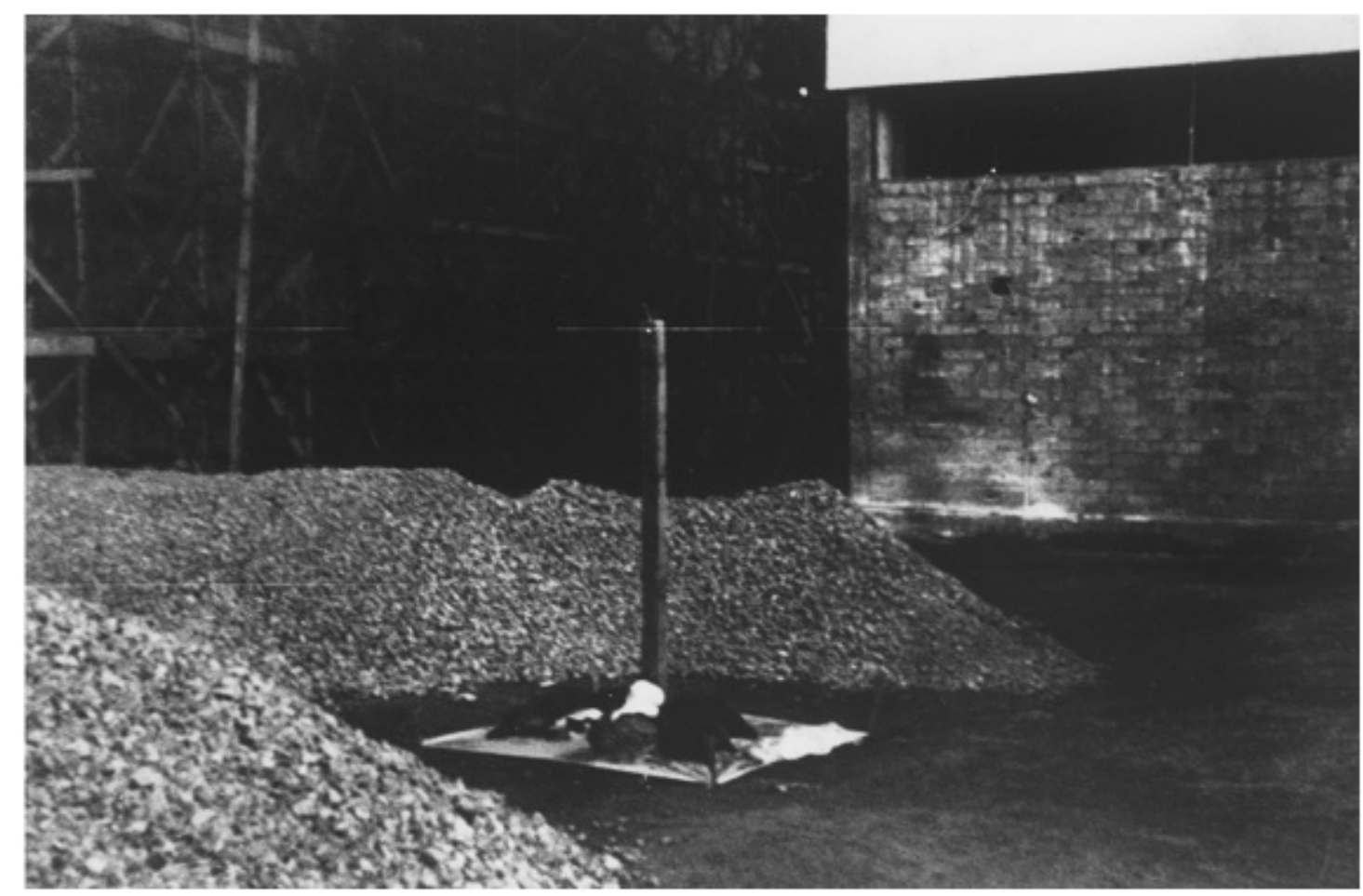

Figura 47 - Tiradentes: Totem-monumento ao preso político, Cildo Meireles Estaca de madeira, tecido branco, termômetro clínico, 10 galinhas, gasolina, fogo, 1970

Já o artista Lee Jaffe, representando Hélio Oiticica que nesse momento vivia em Nova Iorque, lançou uma trilha de açúcar sobre a terra vermelha da Serra do Curral, que logo depois foi destruída por tratores de uma empresa mineradora. Do corpo à terra, de acordo com Frederico Morais,

foi uma proposta mais radical, por seus aspectos inovadores, quase uma ilustração da teoria da 'guerrilha artística' [...] A surpresa, o improviso [...] a precariedade dos materiais e dos suportes empregados são algumas das 
táticas usadas por guerrilheiros em suas ações que foram absorvidas pelos artistas. $^{154}$

Arte e Ideología. CAYC al Aire Libre e Do Corpo à Terra foram duas manifestações emblemáticas que buscaram ativar o espaço público e a sua relação com os transeuntes por meio de intervenções artísticas fora dos moldes tradicionais. O sentido de guerrilha cabe nas duas ocasiões, na medida em que prospectaram trabalhos de arte como "uma forma de emboscada" em lugares inesperados, provocando um estado permanente de tensão.

Veremos a seguir o estudo de caso sobre as obras do artista argentino Horacio Zabala, integrante do Grupo de los trece que participou de diversas exposições organizadas pelo CAYC. Por meio do intercâmbio institucional realizado entre Jorge Glusberg e Walter Zanini, Zabala expôs em algumas mostras do MAC USP ao longo da década de 1970, como Prospectiva 74 e Década de 70. Ambas instituições constituíram-se como lugar de ativação das propostas artísticas do período, buscando legitimar as ações e experiências dos artistas por meio de exposições, convocatórias e uma intensa rede internacional. Cada uma à sua maneira, como analisaremos no $3^{\circ}$ capítulo.

${ }^{154}$ Entrevista concedida à Marília Andrés Ribeiro. In: Revista UFMG, Belo Horizonte, v. 20, n.1, p. 336-351, jan. - jun. 2013.

https://www.ufmg.br/revistaufmg/downloads/20/18-entrevista_fredrico_morais.pdf. Acesso em 01 jun. 2015. 


\subsection{2 - ESTUdO de CASO: OS MAPAS de HoRACIO ZABALA}

Em 1972, o artista e arquiteto argentino Horacio Zabala escreveu: "a arte se define pela função que cumpre na sociedade, pois nem o fazer artístico nem seus resultados são autônomos: a arte depende do que não é arte". ${ }^{155}$ Esse trecho contribui para refletir sobre as ações artísticas ao longo dessa década e a emergência de uma produção que evidenciasse que o significado de uma obra não residia em si mesma, mas através de si, ou seja, que ela era formada pela sua relação direta com o exterior.

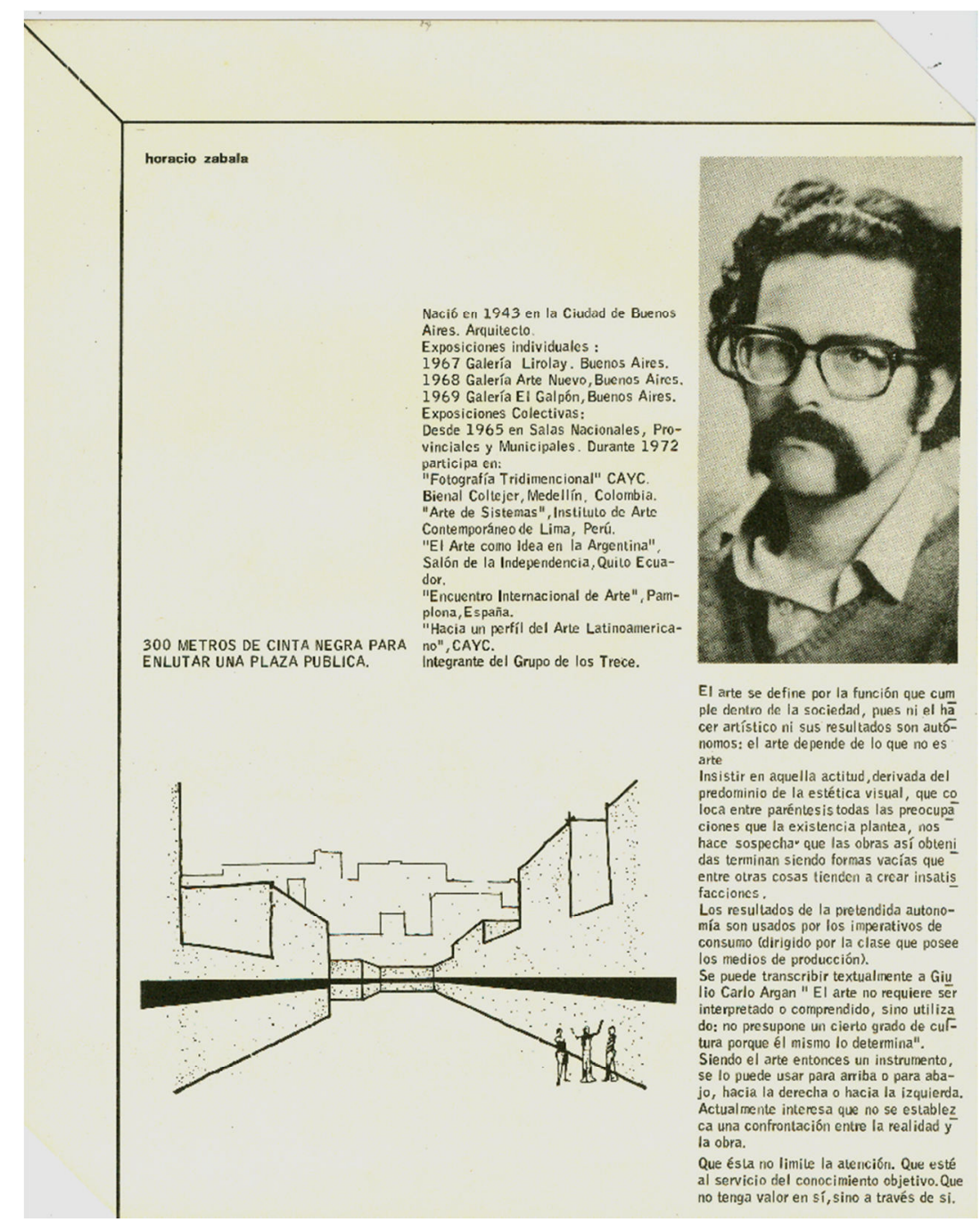

Figura 48 - 300 metros de conta negra para enlutar uma plaza publica (cat. exp.), Horacio Zabala CAyC al aire libre. Buenos Aires, 1972

${ }^{155}$ In: ZABALA, Horacio. CAYC al aire libre (cat. exp.), Buenos Aires, 1972. 
Esse ponto de partida colaborou para ampliar o papel da obra de arte como agenciadora ou catalisadora de questões sociais e políticas; uma ferramenta subjetiva capaz de relevar distintas relações de poder, que a princípio pareciam não ser uma pauta importante das preocupações de ordem estética. Contudo, sabemos com Rancière que estética "é uma matriz de percepções e discursos que envolve um regime de pensamento, bem como uma visão da sociedade e da história" ${ }^{156}$. Se o discurso modernista neutralizou o objeto artístico, sobretudo o pictórico, inserindo-o em uma ficção linear cujo ápice foi a descoberta de seu médium próprio - a superfície bidimensional - uma revisão crítica dessa conjuntura autônoma da arte buscou contaminar seu regime com outras ficções. Diga-se, outras realidades, novas formas de vida que propuseram articular o fazer artístico e político em um momento de aceleradas adversidades sociais. A tomada de consciência do artista latino-americano diante de um panorama devastador de governos de exceção nasceu como um limite à lógica do repressor, uma vontade de contrariá-la. Dessa fricção surgem insurgências artísticas que engendram novos modos de ação no campo da arte, uma espécie de efeito boomerang na qual a ordem vigente e cega acaba por produzir os seus próprios limites.

Chamaremos esse espaço de fricção e potencialidades entre estética e política de "arte fronteiriça", mesma categoria que Luis Pazos e Juan Carlos Romero usaram na conferência "El arte como conciencia en la Argentina"157, quando se referiram à circulação dos termos importados "arte conceitual" e conceitualismos na Argentina. "Uma arte fronteiriça, nada definitiva ainda [...] para inverter o processo político e cultural que diz respeito à realidade

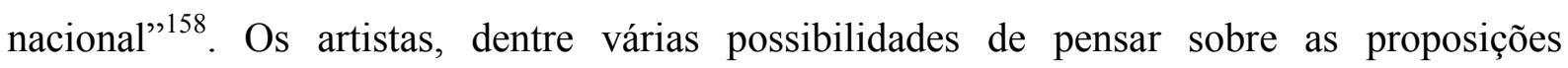
conceituais, escolheram uma categoria geográfica - fronteiriço - para situar esse conjunto amplo e complexo de práticas ainda em desenvolvimento na América Latina. Uma arte de fronteira, nesse momento, apontava para dois problemas fundamentais: 1- a redefinição do conceito de arte e do objeto artístico; 2- uma forma estratégica para discutir a realidade social e econômica da região. A precariedade dos materiais, por exemplo, em sintonia com essa realidade, foi assumida como um conjunto de proposições críticas. $\mathrm{O}$ conceitualismo tornouse, então, uma categoria tática, um meio de expressão política, eficaz, acessível e de baixo custo.

\footnotetext{
156 Em: http://cargocollective.com/ymago/Ranciere-Txt-2. Acesso em 25 maio 2015.

${ }^{157}$ Monzón, Hugo. Dos muestras de arte conceptual exhiben divergentes propuestas, La Opinión, Buenos Aires, 19 de julio de 1972. In: http://www.ramona.org.ar/node/21556. Acesso no dia 16-06-2015

${ }^{158}$ Ibidem.
} 


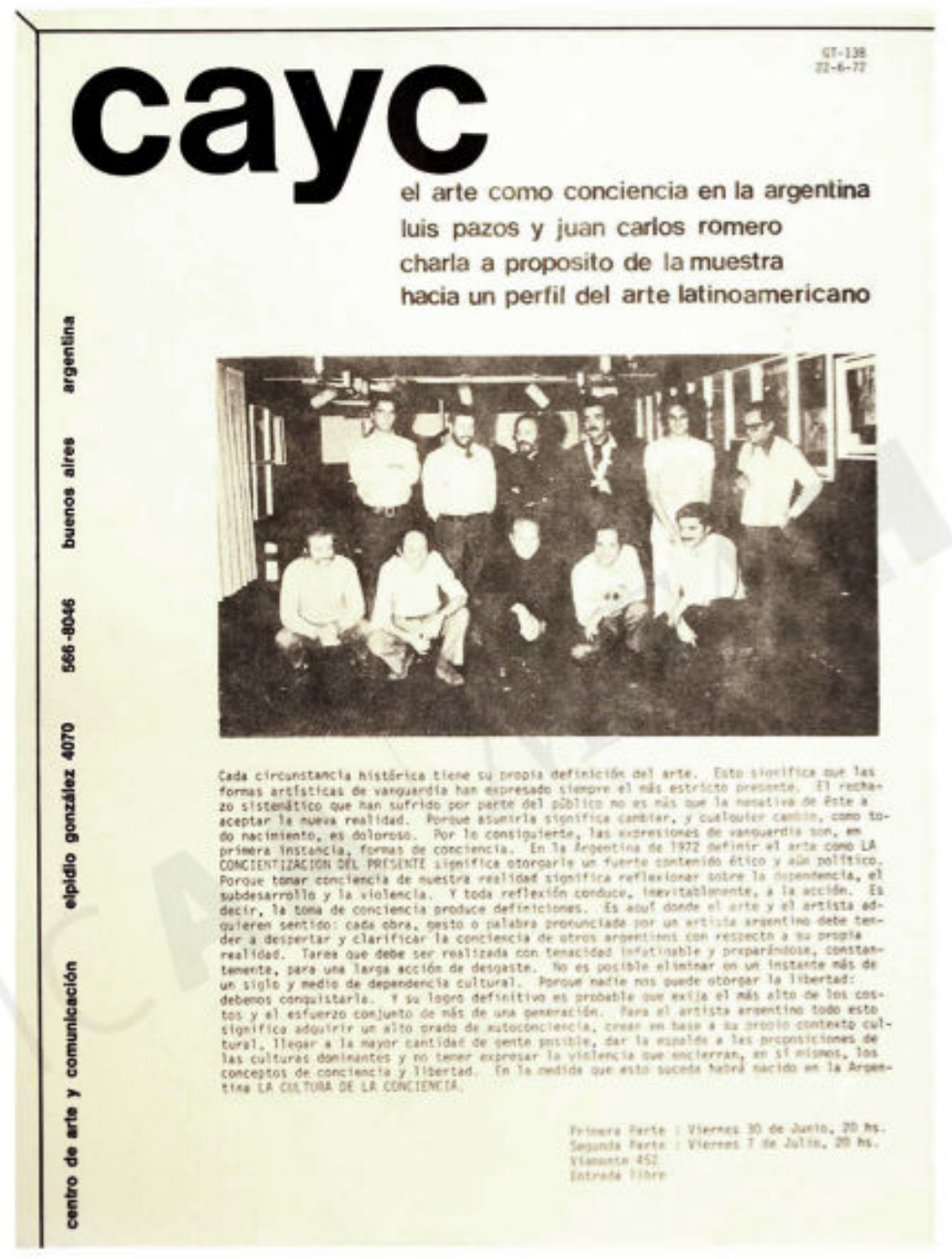

Figura 49 - El arte como conciencia en la Argentina

Gacetilla GT 138 22-06-72. ICCA - Documents of 20th-Century Latin American and Latino Art

A emergência de uma "REAL ARTE POBRE"159, segundo Edgardo Antonio Vigo, com a circulação descentralizada e pela via de canais colaborativos; o uso do papel heliográfico como um "sistema econômico e facilmente reprodutível [...] próprio de nossa impossibilidade de competir com meios tecnológicos e possibilidades econômicas que ainda não dispomos" "160; ou "o máximo de possibilidades com um mínimo de recursos",161, constituíram-se como ponto de partida desses programas conceituais fronteiriços. A redução dos recursos formais, materiais e técnicos como um código estético e crítica institucional cada vez mais distantes da lógica do espetáculo dialogavam com a máxima "menos é mais".

\footnotetext{
${ }^{159}$ Revista Hexágono 71.

${ }^{160}$ GLUSBERG, Jorge. Em: Hacia un perfil del arte latinoamericano. (cat. exp.), Buenos Aires, 1971.

${ }^{161}$ ZABALA, Horacio. Diecisiete interrogantes acerca del arte. CAYC, Buenos Aires. GT-135, 1972.
} 
As diversas séries de cartografias realizadas nesse período por Horacio Zabala seguiram a operação de trabalho com um mínimo de recursos possíveis, em reciprocidade com as ações de caráter fronteiriço. $\mathrm{O}$ artista se apropriava de imagens impressas de mapasmúndi, mapas escolares de fácil acesso, baratos e legíveis, transformando essa linguagem conhecida em uma geografia desfigurada. O método típico do ofício de arquiteto, de saber rigoroso e matemático, era coerente com as escolhas imagéticas de Zabala: mapas, plantas baixas, projetos de arquitetura de prisão; quer dizer, modelos de diferentes escalas e reduções espaciais de um território. Em alguns mapas da série enviada ao MAC USP para a exposição Prospectiva 74, intitulada Integração de linguagens poéticas experimentais com investigações sociais e econômica (1974), Zabala propôs o embaralhamento das fronteiras territoriais ao colar um pedaço do mapa dos Estados Unidos e do Canadá em cima da América do Sul. Em outro, o continente é novamente tampado por uma colagem de diversos fragmentos do Oceano Atlântico e do Pacífico, alterando a lógica espacial e recriando um jogo de novas fronteiras que é apenas evidenciado pelo mosaico de recortes colados. Três recibos de compra em branco são fixados sobre a América Latina, sugerindo que a venda do continente pode vir a ser negociada mediante qualquer proposta. As investigações sociais e econômicas conduzidas pelo artista nos fazem recordar como as cartografias foram dispositivos basais para a legitimação do êxito colonial; e como a partilha dos países ocupados continuou a ser um exercício constante de poder na história das conquistas.

Do ponto de vista do método artístico, Zabala se apropriava de um padrão técnico e racional de representação espacial supostamente neutro para desconfigurar a totalidade desse lugar escolhido e distorcer tal realidade reduzida em um papel. Falando nesse material, vale fazer uma breve digressão para compreender melhor o pensamento estético ou, de acordo com o próprio Zabala, uma ideia dentro de uma operação sócio-estética ou sócio-artística. 

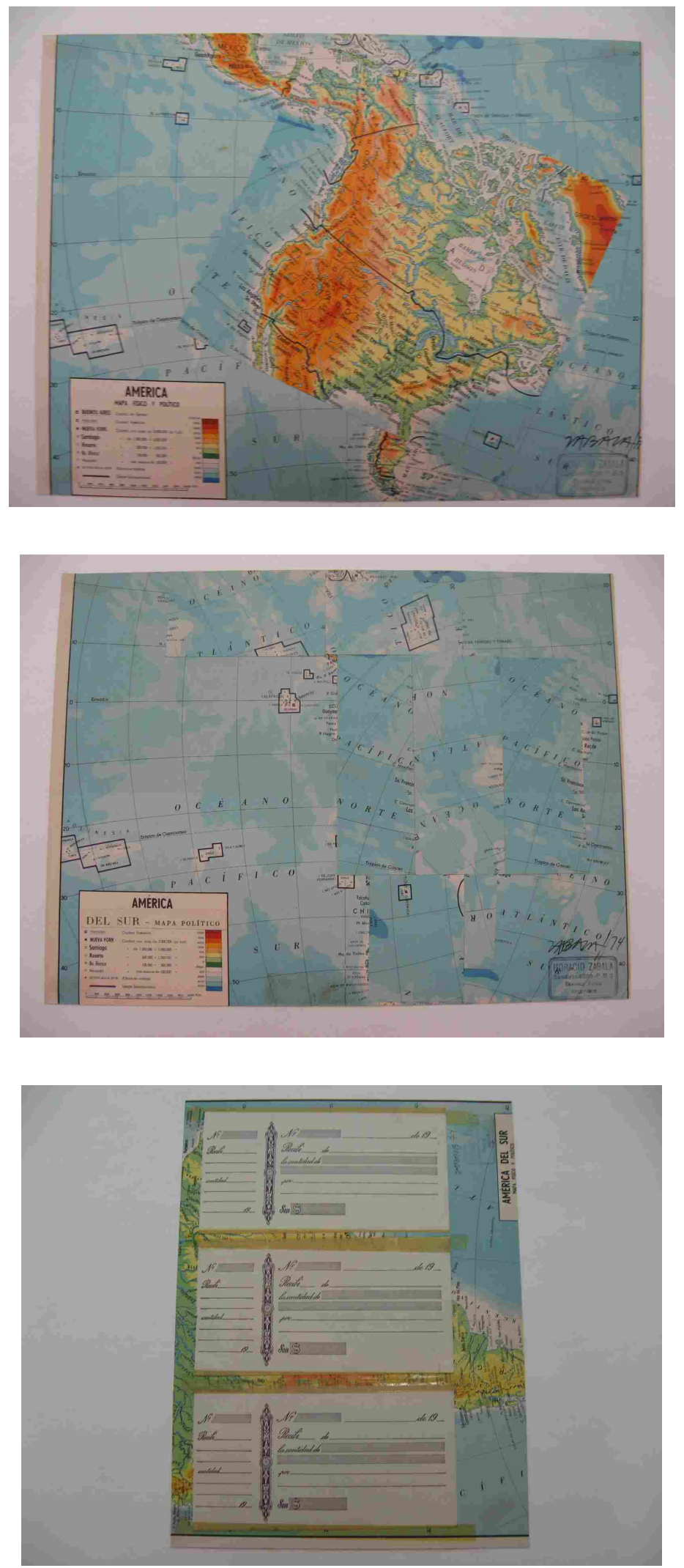

Figura 50 - Integração de linguagens poéticas experimentais com investigações sociais e econômicas Horacio Zabala

Selo, datilografia e tipografia sobre envelope, fita adesiva, papel carbono e carimbo sobre mapa impresso (Detalhe), 152,5 x $75 \mathrm{~cm}$, Coleção MAC USP 
Nota-se um fio condutor em seu modus operandi artístico, lembrando que o papel já aparecia como instrumento crítico na obra Este papel es una cárcel (1972), um material cuja área podia acarretar constantes limitações no exercício criativo do artista, um trabalho auto referencial que questionava a bidimensionalidade do papel como um tipo de território reduzido. A prisão-papel se desdobraria logo depois como metáfora do circuito artístico. Contudo, a metáfora da prisão seria extrapolada na experiência concreta da violência na esfera cotidiana e sobre o corpo, destino real de milhares de prisioneiros políticos. Sueli Rolnik nos esclarece que o artista agrega a camada política da realidade à sua investigação poética pelo fato de a ditadura incidir em seu corpo, sob uma atmosfera opressiva onipresente em sua experiência cotidiana. (ROLNIK, 2009, p. 156)

Voltando à análise dos mapas, pegaremos emprestado alguns conceitos do geógrafo brasileiro Milton Santos para repensar o estatuto da cartografia enquanto espaço revelador das multiplicidades do real que não são contempladas pelos discursos hegemônicos e pela lógica racionalizante. Leremos as obras cartográficas de Zabala na chave de uma reivindicação por uma experiência espacial política, uma forma de propor outras construções simbólicas no espaço vivido, que é o que passa pela dimensão do humano, por sua produção e que é transformado pela sua presença. O exercício artístico e a mobilização da imaginação na criação de outros territórios possíveis entram em sintonia com a proposta de geografização da cidadania (SANTOS, 1998), que busca avançar da cidadania abstrata à cidadania concreta, levando em conta os direitos territoriais e os direitos culturais como contraponto "à burocratização do mundo, na qual tudo tende a organizar-se com base na razão instrumental, técnica, no princípio da produtividade, lucratividade, quantidade” (IANNI, 1995, p. 121).

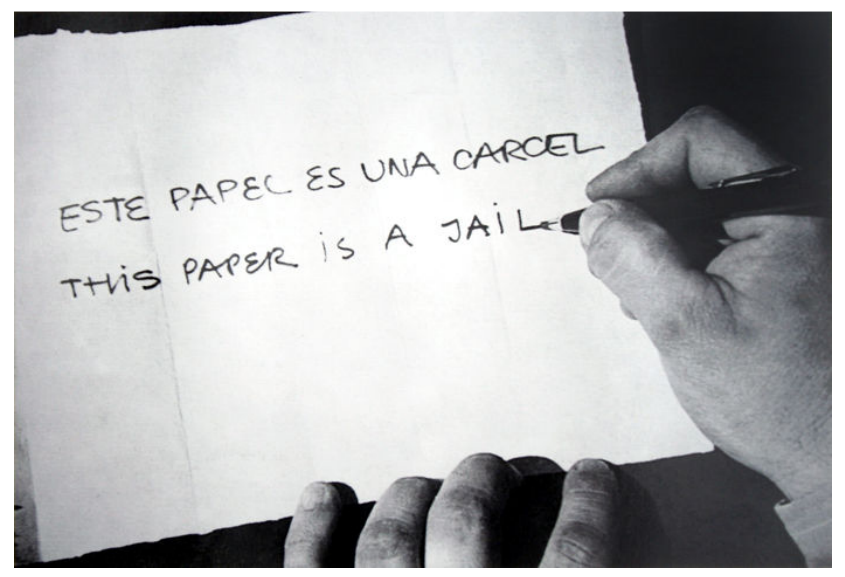

Figura 51 - Este papel es una cárcel, Horacio Zabala Fotografia, 1972 
O código gráfico dos mapas remete a uma ordem que disciplina, sistematiza e regula as coordenadas geográficas, bem como delimita a identidade dos sujeitos associados a um território exclusivo. $\mathrm{O}$ artista deforma essa lógica em um conjunto de intervenções buscando refletir sobre a violência ocultada nas convenções cartográficas e suas relações territoriais. A geografia tradicional demonstrou inúmeras vezes a dificuldade de levar em conta como os mapas seriam lidos, revelando a sua própria limitação no modo de apresentar informações que fossem além dos dispositivos gráficos. Mapas são abstrações, o que nos induz a perguntar: como representar uma simultaneidade de acontecimentos e constantes disputas espaciais, justapondo camadas de fatos históricos tão complexos em uma única imagem gráfica? Um caminho possível é nos aproximarmos do que Fredreric Jameson chamou de mapeamento cognitivo, no qual o ato de cartografar permite "a representação situacional por parte do sujeito individual em relação àquela totalidade mais vasta e verdadeiramente irrepresentável, que é o conjunto das estruturas da sociedade como um todo" (JAMESON, 2004).

Nesses territórios imaginados, Zabala utilizou o fogo diversas vezes como elemento expressivo e como metáfora de algo que estava na iminência de se devastar e queimar. As cartografias da América Latina ardiam com a combustão em Mapa quemado (1974) e Seis imágenes del fragmento 30 (1973), onde um mapa queimado e um trecho do filósofo Heráclito sugerem o fogo como elemento "eternamente vivo", ou seja, permanente arma de combate e combustível criativo. O fogo reaparece implicitamente em obras posteriores, incitando um ambiente de tensão no qual o artista pode vir a ser um ativista cujas armas tornam-se ao mesmo tempo instrumentos poéticos e combativos. 


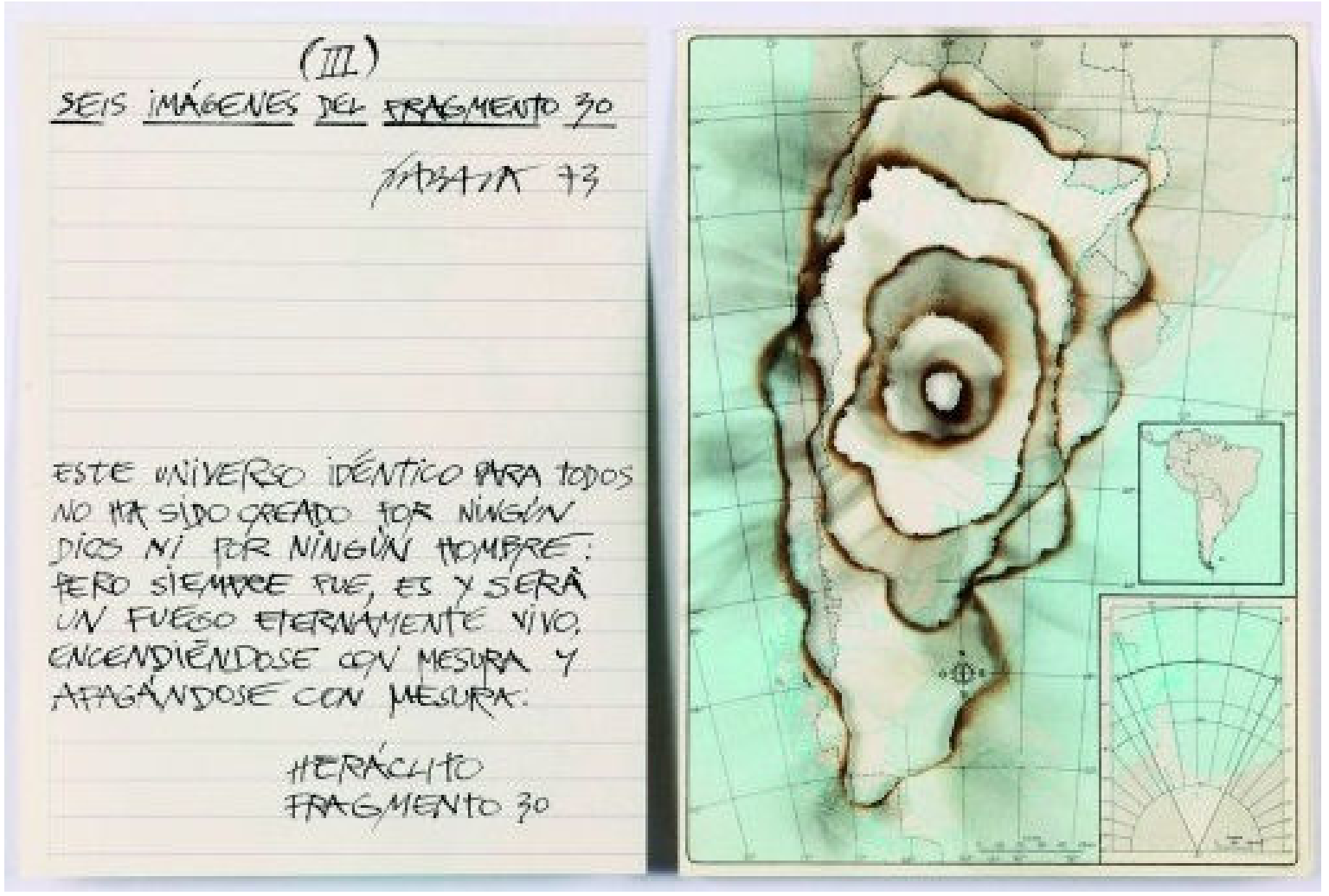

Figura 52 - Seis imágenes del fragmento 30, Horacio Zabala Grafite sobre papel e mapa impresso queimado, 1973

A insinuação da violência como postura revolucionária também foi aludida em obras como Forma y función (1972-2011) e Mira como tiemblo (2002): receitas de coquetel molotóv com materiais inflamáveis para mudar a realidade. Além do fogo, Zabala utilizou o carimbo em diversas cartografias, como é o caso das áreas "revisadas". A recriação de mapas com o par de carimbos revisar - censurar por toda a extensão latino-americana, advertia sobre a situação de intensa repressão e violação dos direitos humanos. O jogo entre imagem e palavra foi um recurso amplamente utilizado nesse período. Zabala e outros tantos artistas criaram um léxico próprio, no qual um conjunto de ideias convergia para uma única palavra. Por sua vez, a palavra também ganhou um novo sentido, transformando-se em uma ferramenta necessária de convocações coletivas para a realização de uma ação. Revisar - Censurar virou uma espécie de assinatura do artista, lembrando que o anonimato poderia servir como tática para a circulação de obras por diferentes territórios sob controle. 


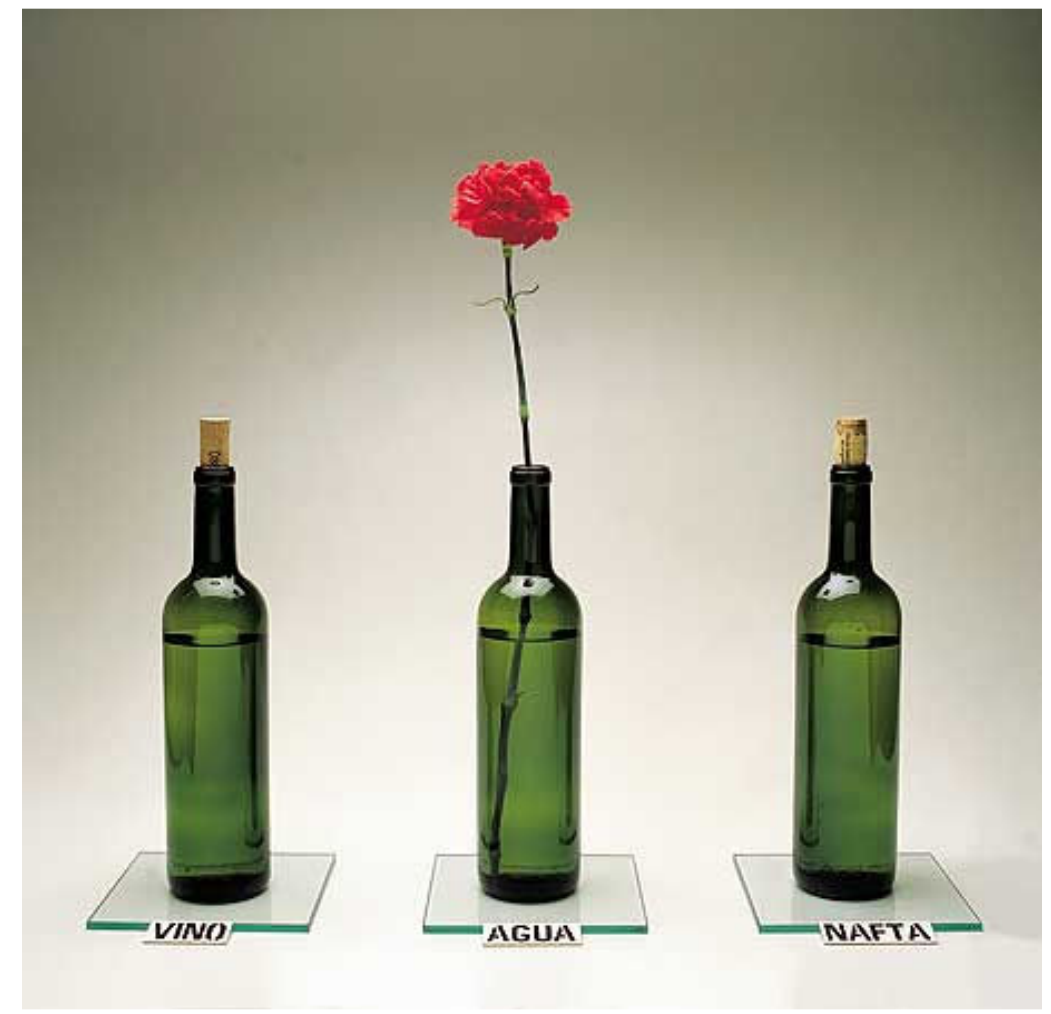

Figura 53 - Forma y función, Horacio Zabala

Garrafas de vidro, líquido, flor, texto sobre papel, 1972-2011

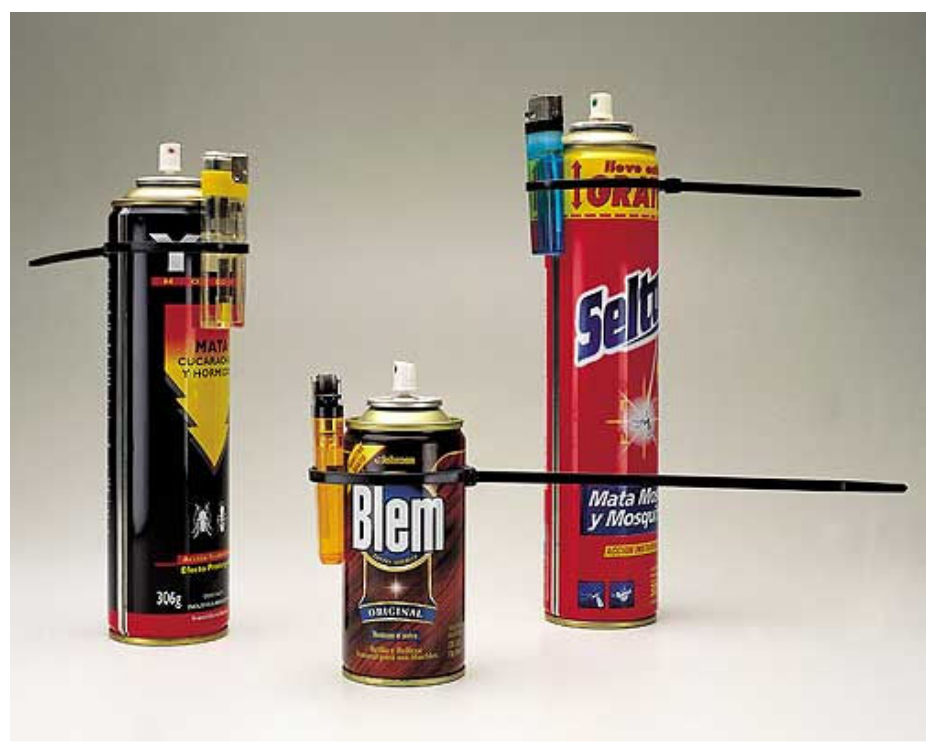

Figura 54 - Mirá como tiemblo, Horacio Zabala

Tubo de aerossol e isqueiro, 2002 
Sabemos que o espaço foi utilizado, em quase toda parte, como veículo do capital e instrumento da desigualdade social. "Impossível chegar a uma sociedade mais igualitária sem reformular a organização do seu espaço”, dizia Milton Santos (2004). Como parte de um consistente programa teórico e geopolítico que visasse planejar uma reconfiguração espacial menos díspar, o geógrafo criou dois conceitos - tecnosfera e psicosfera (2008), que darão novos matizes à discussão sobre os mapas artísticos de Zabala. $\mathrm{O}$ primeiro seria referente ao espaço da ciência e da tecnologia, que reproduz relações verticais e hierárquicas, vetores de uma racionalidade superior que criam um cotidiano obediente e disciplinado. A segunda seria o "reino das ideias, crenças, paixões e lugar da produção de um sentido, também faz parte desse meio ambiente, desse entorno da vida, fornecendo regras à racionalidade ou estimulando o imaginário" (SANTOS, 2008, p. 255). Podemos reformular alguns problemas suscitados por essas cartografias latino-americanas à luz desses termos, sobretudo, a psicosfera enquanto ambiente potencializador da criação e de novos sentidos para a vida, um contraponto aos processos disciplinadores da experiência, o território por excelência da subjetividade e do fazer artístico fronteiriço, lugar onde cabem outras formas de expressão que seguem sua própria lógica. Seguindo esse viés, é válido localizar nesse "reino das ideias, crenças e paixões" o esforço do artista de tornar ilegítima a organização dos espaços de poder indispensáveis para a reprodução das interações políticas e econômicas desiguais. $\mathrm{Na}$ psicosfera de Zabala, o desejo de tornar a ordem racional ilegível é intensificado por meio de intervenções poéticas que deformam as áreas territoriais que ora são tomadas por carimbos, fogo, tinta, ora são embrulhadas, recortadas e até golpeadas por um machado.

O crítico Fernando Davis pensa os mapas de Horacio Zabala a partir dos polos opaco e transparente. A imagem opaca produz fugas e turbulências do sentido que perturbam a racionalidade que organiza a sintaxe cartográfica. A "transparência" desse sistema que baseia sua lógica e funcionamento na economia de recursos e na neutralização da ambiguidade dos signos é subvertida em novas geografias. "As obras de Zabala traçam uma cartografia da opacidade" (DAVIS, 2007, p. 76). Acrescentaremos uma outra leitura para o significado de opaco, novamente com a contribuição de Milton Santos. Partindo da ideia de que Zabala propõe uma contracartografia, suas obras podem se situar no terreno das contrarracionalidades (2008) produzidas em 
[...] áreas menos modernas e mais "opacas", tornadas irracionais para usos hegemônicos. Todas essas situações se definem pela sua incapacidade de subordinação completa às racionalidades dominantes, já que não dispõem dos meios para ter acesso à modernidade material contemporânea. Essa experiência da escassez é a base de uma adaptação criadora à realidade existente (SANTOS, 2008, p. 309)

A experiência da escassez como campo privilegiado de outros saberes da contrarracionalidade que a análise geográfica nos revela é esclarecedora para articular os programas estéticos que esses artistas, entre os quais o próprio Zabala, pautaram suas produções críticas. O geógrafo propõe esse termo para estudar as relações desiguais entre cidade e campo e a constituição, por parte das minorias, de estratégias contra-racionais como resistência à lógica hegemônica. Nesse sentido, as contrarracionalidades são novos modos de fazer vida, são os saberes da arte fronteiriça que buscavam ativar cada vez mais a sua relação com o entorno e com as demandas sociais, friccionando o diálogo entre a estética e a política, dentro do que foi denominado por Rancière como partilha do sensível (2009). As cartografias de Zabala podem ser lidas na zona de fronteira entre esses dois regimes que definem ao mesmo tempo o lugar e o que está em jogo na política como forma de experiência (2009, p. 16). 


\section{Capítulo 3}

\section{INTERCÂMbio INSTITUCIONAL ENTRE BRASIL E ARgENTINA NA DÉCADA DE 1970}

Para estabelecer os vetores de troca entre o CAYC e o MAC USP, na década de 1970, é necessário voltar brevemente à história da formação do Museu de Arte Contemporânea da Universidade de São Paulo, para compreendermos melhor o seu perfil institucional. Sobretudo, a gestão de Walter Zanini, que dirigiu o Museu entre 1963 a 1978. Sabemos que o MAC USP fora fundado após a doação do acervo do MAM SP à Universidade. A USP passava por um período estimulante de interesse pela área das Humanidades e das Artes, e seu novo campus acenava positivamente para a criação de projetos antes impensados, conforme relatou Ulhôa Cintra (apud AMARAL, 1988, p. 31), o então reitor da Universidade naquele momento: "Tudo parecia possível. Sentia-se um enorme interesse em ver a Universidade crescer, a qualquer necessidade [...] e as responsabilidades novas como reitor fizeram-me aproximar de áreas como Filosofia, a História, e as Artes [...]”. O clima para a instauração de um Museu universitário era bastante favorável.

A formação da coleção do MAM SP, origem do MAC USP, se deu por meio de doações e aquisições, especialmente, da coleção do casal Yolanda Penteado e Francisco Matarazzo Sobrinho - o Ciccillo - fundador do Museu de Arte Moderna e da Bienal de São Paulo. Contava, também, com sete obras doadas por Nelson Rockfeller, que simbolizava, em certa medida, o vínculo do museu paulista às diretrizes museológicas do MoMA de Nova Iorque. Vale lembrar que parte da formação do acervo inicial do MAM SP foi adquirida por meio de prêmios-aquisição da Bienal de São Paulo, até 1962.

No decorrer dos dez primeiros anos da entidade, o MAM SP constituiu-se pela ampla programação de exposições e cursos de história da arte. Contudo, a Bienal foi se afirmando e assumindo protagonismo cultural na região e centralizando parte do apoio financeiro que vinha dos contatos de Ciccillo com embaixadas, empresas privadas, e no final de década de 1950, com o governo federal. O MAM gradualmente foi ficando em segundo plano e a sua instabilidade institucional foi se ampliando com uma série de problemas ligados à direção do Museu, marcada pelo conflito entre os seus diretores e a figura centralizadora de Ciccillo. Em 1960, Mário Pedrosa assumiu a direção do Museu e buscando uma saída para a crise, propôs 
que a entidade buscasse patrocínio. Entretanto, os planos do crítico não tiveram sucesso. Três anos depois, Ciccillo organizou uma Assembleia na qual decidia pela extinção do MAM e a doação de seu acervo para a Universidade.

Desse modo, foi conduzida a integração do acervo do MAM à Universidade de São Paulo, em 1963, e criada a entidade museológica para receber a sua coleção: o MAC USP. Como vimos, Walter Zanini, recém-chegado da Europa onde obtivera o título de doutor, ficou responsável pela primeira gestão do Museu. Na época, a prefeitura de São Paulo cedeu o terceiro andar do pavilhão da Bienal, no parque Ibirapuera, enquanto a Universidade não construísse a sua sede própria. Um museu vinculado à Universidade era caracterizado pela sua missão educacional, constituindo-se assim, como importante foco de pesquisa, criação e experimentação.

Um dos primeiros pontos de partida de Zanini foi conservar e ampliar a coleção transferida para a Universidade.

Na sua práxis cotidiana, pensar no Museu era fazê-lo existir. Isso implicou em organizar frentes de trabalho com o mínimo de recursos, orientar um programa de ação em sólidas bases teóricas e, principalmente, apoiar-se nessa rede de colaboradores fiéis que forneciam um sustento solidário para lidar com a profusa burocracia da universidade pública (FREIRE, 2013, p. 26)

O programa inicial de atividades do Museu visava fomentar seu acervo de arte moderna, por meio de exposições e retrospectivas de artistas brasileiros como Antônio Gomide, em 1968, Tarsila do Amaral, em 1969, Vicente do Rêgo Monteiro, em 1971, entre outros. Além disso, contou com a divulgação de toda a programação da entidade feita por meio de boletins informativos, que procuravam informar toda a agenda de atividades, desde a abertura de mostras à presença de artistas estrangeiros, conferências, cursos, etc. O MAC USP realizou, também, diversas mostras itinerantes pelo interior de São Paulo, procurando expandir e descentralizar os focos de cultura da capital paulistana. Segundo Zanini, o intuito era criar "um museu constantemente empenhado em exposições itinerantes com o objetivo de intercâmbio e para favorecer a penetração da arte em meios distantes dos centros maiores de cultura" (ZANINI, 1964). ${ }^{162}$ Além da função de diretor, Zanini problematizou seus desafios museológicos e escreveu sobre arte contemporânea em jornais, catálogos de exposição,

${ }^{162}$ Problemas museológicos. O Estado de S. Paulo, São Paulo, 4 jan. 1964. In: FREIRE, Cristina. (Org.). Walter Zanini: Escrituras Críticas. São Paulo: Annablume: MAC USP, 2013 
publicou uma série de livros fundamentais para a história da arte brasileira, lecionou na USP e posteriormente na FAAP, participou e organizou colóquios nacionais e estrangeiros. Destacamos a fundação da AMAB - Associação de Museus de Arte do Brasil, iniciativa que promoveu junto com Ulpiano Bezerra de Meneses, em 1967, em um momento emergencial para debater sobre o papel social dos museus, sobretudo, os dedicados à arte contemporânea. O objetivo maior era unir os museus de arte públicos e privados a fim de ampliar uma rede de atividades culturais e educacionais de cada entidade.

Como vimos, o MAC USP herdou do MAM uma coleção de ilustres artistas da história da arte como Picasso, Miró, Modigliani, De Chirico etc. O encargo de gerir uma instituição com um acervo de obras-primas comparáveis aos grandes museus da Europa e EUA, atribuía estabilidade e prestígio ao MAC USP, ratificando a sua função tradicional de salvaguardar obras de renome. Contudo, essa noção convencional do Museu como depositário de obras consagradas foi redimensionada ao longo da gestão de Zanini, tornando-se referência para a arte contemporânea, "atraindo exibidores e visitantes ávidos por mudança tanto, na esfera artística como também na política" (JAREMTCHUK, 2007, p. 60). Se uma das frentes do Museu era amparar a organização do inventário, da pesquisa e da apresentação do acervo moderno, o outro projeto paralelo de Zanini baseava-se no estímulo da produção contemporânea.

Sua prospectiva era aglutinar artistas estabelecendo no Museu uma plataforma de criação interdisciplinar e multimídia; núcleo potente de uma rede transnacional de comunicação e trocas artísticas. Configura-se, a partir daí, um partido crítico e museológico que daria ênfase às práticas artísticas conceituais, incentivando o uso das novas tecnologias, em especial o vídeo. Anima igualmente a formação de redes de artistas para trocas de informações e projetos (FREIRE, 2013, p. 28).

Desde o seu ano de inauguração, o Museu criou uma mostra anual para jovens artistas de até 33 anos. As primeiras, conhecidas como Jovem Desenho Nacional - JDN (1963-1965) e Jovem Gravura Nacional - JGN (1964), eram destinadas à produção de desenho e gravura. Devido ao crescimento do número de inscritos e à projeção entre os artistas, inclusive os mais jovens, ainda não consagrados, as mostras passaram por transformações no formato, sendo renomeadas de Jovem Arte Contemporânea - JAC (1967-1974). Desde as primeiras edições, buscava-se distanciar dos formatos tradicionais dos salões e seus mecanismos de premiação. A I JAC, de 1967, já evidenciava o caráter experimental do MAC USP, envolvendo a inclusão de novos suportes de arte para além das categorias tradicionais da pintura e escultura. E 
marcava, também, o Museu como espaço solidário e receptivo de artistas, que permitia um ambiente estimulante de confronto e de novas conjecturas. No texto de apresentação da I JAC, Zanini escreveu:

À diferença do espírito do salon tradicional, com sua hierarquia de prêmios, suas medalhas, seus fins predominantemente consagratórios, as exposições do MAC USP procuram desempenhar um papel estimulante, e seu objetivo é antes o de despertar e revelar, embora também seja um certame em que os melhores valores podem encontrar a oportunidade da afirmação e da ratificação de suas qualidades. ${ }^{163}$

Porém, até a VI JAC ${ }^{164}$, de 1972, as exposições ainda prosseguiam estruturalmente um formato mais convencional, composto por júri e obras inscritas; premiação e seleção; limite de idade e etc. É na sexta edição que se observa uma maior radicalização dessas propostas: a começar pela eliminação de um corpo de jurados que seleciona e legitima um determinado grupo de obras. Essas decisões foram fruto de um amplo debate entre artistas, jurados e o próprio museu, que ocorreu desde o ano anterior à inauguração da VI JAC, evidenciando o papel de diálogo e construção mútua entre museu e artista. A inscrição foi irrestrita a qualquer interessado, ocasionando a participação de artistas consagrados junto aos pouco conhecidos. Mas esta mostra tornou-se emblemática, especialmente, por transformar o espaço expositivo do museu em lotes, que seriam sorteados entre os interessados. Os 210 artistas inscritos tiveram que sortear 84 lotes dentro do MAC, e no decorrer dos 14 dias de processo, esses espaços poderiam ser negociados, trocados e até vendidos.

O artista Gabriel Borba, por exemplo, que havia sido recusado na seleção de duas JACs anteriores e não havia sido sorteado para a sexta, recebeu a doação do lote 9 . A proposta desenvolvida por Borba nesse espaço se chamava À Brecht - A exceção e a regra, e consistia na organização da documentação produzida pela burocracia do MAC, buscando problematizar os mecanismos de legitimação ou recusa de obras de arte dentro do circuito artístico, inclusive, do qual o MAC fazia parte. (LOUZADA, 2013, p. 30). Em entrevista, Zanini contou sobre a experiência dos artistas nessa exposição:

\footnotetext{
${ }^{163}$ Apresentação - I Exposição Jovem Arte Contemporânea. In: FREIRE, Cristina. (Org.). Walter Zanini: Escrituras Críticas. São Paulo: Annablume: MAC USP, 2013.

${ }^{164}$ Sobre a VI Jovem Arte Contemporânea, ver: JAREMTCHUK, Dária. Jovem Arte Contemporânea no MAC USP. Dissertação de Mestrado. Escola de Comunicações e Artes, Universidade de São Paulo, São Paulo, 1999. E: LOUZADA, Heloisa. Contrastes na cena artística paulistana: MAC USP e MAM SP nos anos 1970. Dissertação de Mestrado. Programa de Pós-Graduação Interunidades em Estética e História da Arte, Universidade de São Paulo, São Paulo, 2013.
} 
Na VI JAC, havia uma pianista a Carole [...] ela ficava ao piano, tinha um substituto também. Ficavam horas repetindo aquela mesma estrofe [...] mas se realizava ali no meio da produção das obras nos lotes, das marteladas, dos gritos. [...] Os artistas ficaram lá duas semanas trabalhando em seus lotes. Ocuparam tudo. Todas as vidraças, a rampa também [...]. Tudo tinha conotações, tinha todo um sentido emblemático. Foi muito interessante. Não se ia lá especificamente ver a qualidade do trabalho, era outra a proposição. ${ }^{165}$

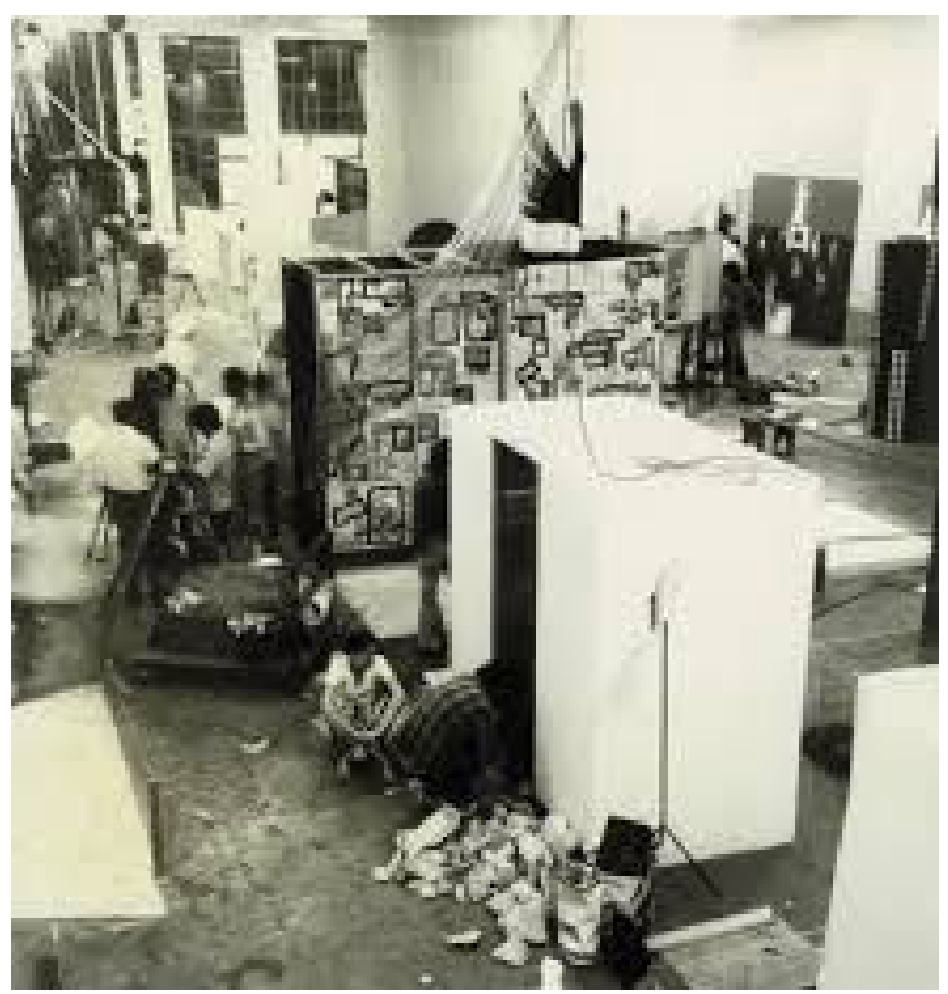

Figura 55 - Vista da VI JAC

MAC USP, 1972

${ }^{165}$ Entrevista concedida à Cristina Freire, que fez parte de uma série de encontros com Walter Zanini, realizados entre 2008 a 2011. In: FREIRE, Cristina. (Org.). Walter Zanini: Escrituras Críticas. São Paulo: Annablume: MAC USP, 2013, p.38. 


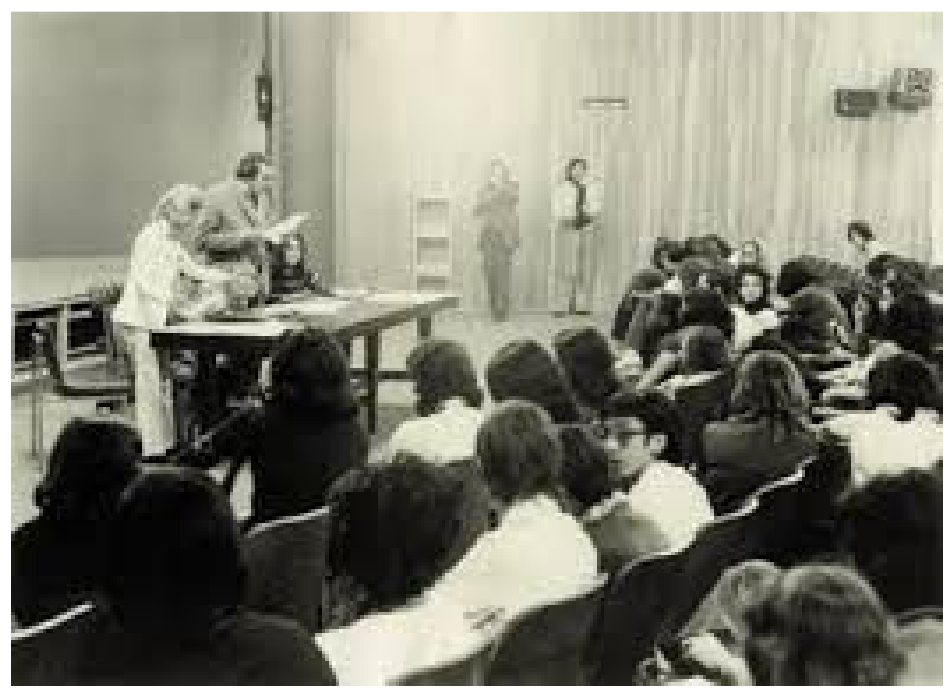

Figura 56 - Sorteio dos lotes da $V I J A C$ MAC USP, 1977

A proposta da VI JAC, idealizada pelo artista Donato Ferrari, era dar espaço às experiências efêmeras, para além da obra de arte como sentido único e imutável. E, sobretudo, localizar o museu dentro desse eixo de atividade criadora, que incentiva o diálogo entre o artista e o público e que rompe com as noções artísticas usuais. Ou, como escrevera Zanini a respeito da mostra e do papel do museu ${ }^{166}$, "não mais na condição de órgão especializado no colecionismo, mas enquanto núcleo capaz de contribuir diretamente na configuração desses processos". O que se buscava, de um modo geral, era tornar possível uma "ampla e direta vinculação do artista com o museu, visando ao mesmo nível a uma fórmula de aproximação com o público"167. O programa dessas mostras representou um momento de mudança no papel e na concepção de um museu de arte contemporânea, pois:

tal programa iniciava uma participação sistemática dos artistas mais jovens ao mesmo tempo em que implementava uma política de aquisição de obras de arte contemporânea, envolvendo artistas emergentes. Muitos dos prêmios das exposições JDN e JACs foram incorporados ao acervo do Museu (FREIRE, 2013, p. 48).

Ainda em 1972, Zanini apresentou um texto no VI Colóquio da AMAB, intitulado $O$ Museu e o Artista, em que se propunha discutir o papel dos novos museus na sociedade contemporânea. Distinto do caráter sacralizado de um museu de arte antiga, cujo papel era o de atribuir valores, os museus contemporâneos deveriam operar em outra lógica, distinta do

\footnotetext{
${ }^{166}$ O Museu e o Artista. In: FREIRE, Cristina. (Org.). Walter Zanini: Escrituras Críticas. São Paulo: Annablume: MAC USP, 2013.

${ }^{167}$ Ibidem.
} 
valor transcendental, trabalhando com diversas frentes, sobretudo, em diálogo constante com os artistas. É válido notar a importância da presença e participação dos artistas na organização de exposições, nas propostas museográficas, no design de catálogos, entre outras funções. Conforme escreveu Zanini nesse texto, o museu deveria demonstrar "a posição do artista consciente de sua própria vinculação com a realidade social, que trabalha no sentido da experimentação e cujas soluções, a exemplo da pesquisa científica, surgem como um processo de desenvolvimento ininterrupto". ${ }^{168}$ O Museu tornou-se uma plataforma solidária, o lugar por excelência de encontros, trocas, reflexões e experimentações artísticas.

Lembremos que a mais importante instituição artística brasileira daquele momento, a Bienal de São Paulo, passava por um período de crise, alavancada por uma série de boicotes. Os protestos foram deflagrados depois que a exposição dos artistas brasileiros selecionados para a VI Bienal de Paris, no MAM RJ, e organizada por Pierre Restany, foi censurada. No âmbito internacional, Restany organizou um boicote à X Bienal de São Paulo, de 1969, que contou com a adesão de delegações de países como a França, EUA, Itália, Suécia, México etc. No Brasil, Mário Pedrosa, o então diretor da Associação Brasileira de Críticos de Arte, mobilizou o boicote que foi aderido por diversos artistas como Lygia Clark, Hélio Oiticica, Carlos Vergara, entre outros. Os boicotes seguiram ao longo de toda a década de 1970, ocasionando diversos problemas e lacunas na organização das Bienais.

Alguns artistas latino-americanos, ligados ao MICLA - Movimiento de Independencia Cultural Latinoamericano, organizaram um movimento de resistência ao regime de repressão brasileiro. Consistia na criação de uma convocatória chamada Contrabienal, que era um livro impresso e desenhado por um coletivo integrado por Luis Camnitzer, Luis Wells, Carla Stellweg, Liliana Porter e Teodoro Maus. Inclusive, Jorge Glusberg, diretor do CAYC, enviou um texto sob o título "Por qué resolvi participar con Art Systems en la Bienal de San Pablo y ahora desisto" (ROSSI, 2010, p. 211). Edgardo Antonio Vigo também participou da convocatória com uma obra gráfica com a sigla TNT e um pequeno texto em que menciona a renúncia de Glusberg à Bienal, "posición personal respetable”. E completa expressando que a reação contra a Bienal não deveria ser feita por meio da experiência do pensamento, mas com ações diretas, aludindo ao uso do explosivo, conhecido como TNT.

${ }^{168}$ O Museu e o Artista. In: FREIRE, Cristina. (Org.). Walter Zanini: Escrituras Críticas. São Paulo: Annablume: MAC USP, 2013. 


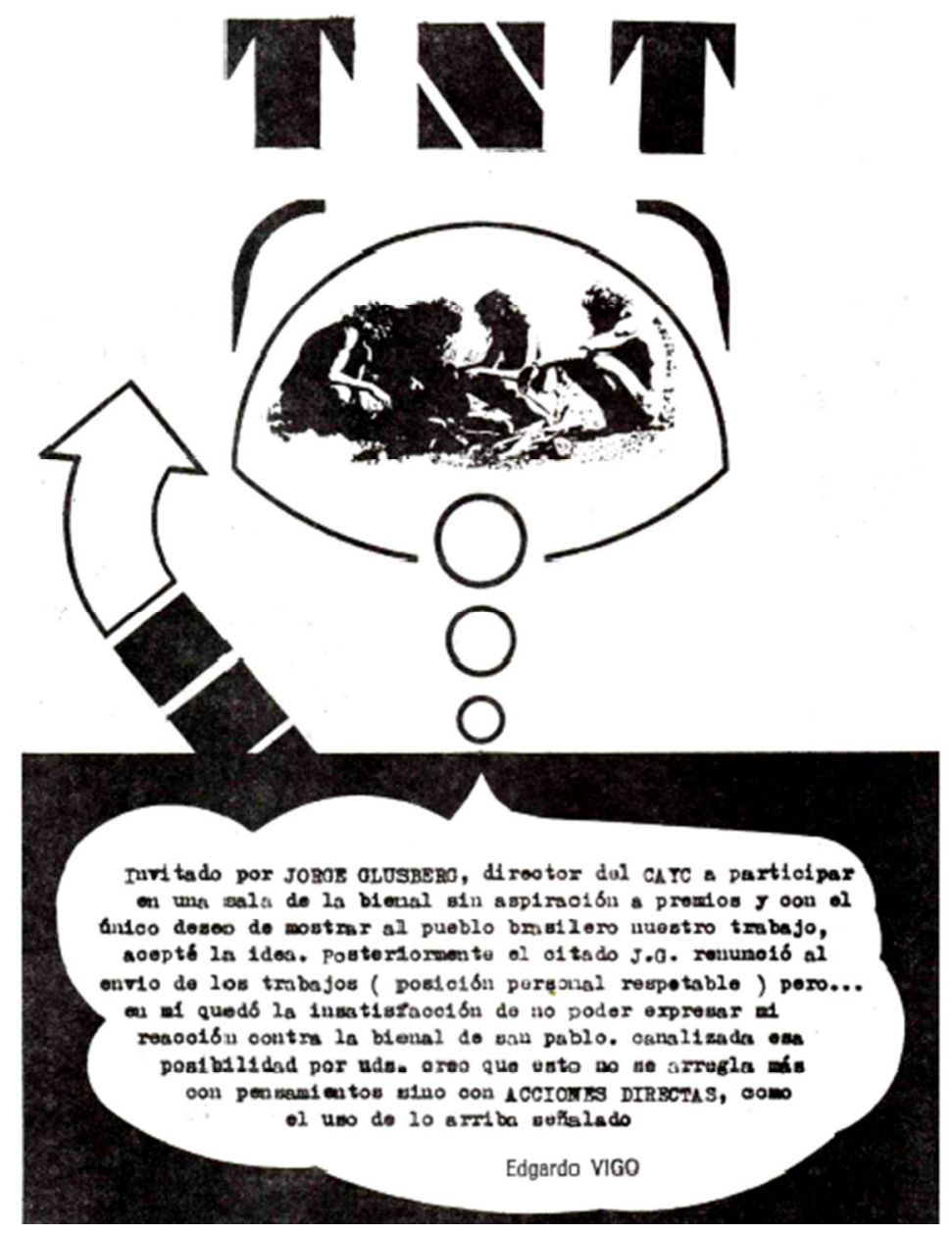

Figura 57 - Edgardo Antonio Vigo. Obra enviada para o livro Contrabienal, 1971. ICCA - Documents of 20th-Century Latin American and Latino Art.

Após a crise institucional da Bienal, o papel do MAC como lugar de encontro e agregador de ideias e reflexões artísticas, tornou-se ainda mais fundamental, aproximando-o da experiência do museu como um laboratório ${ }^{169}$. Embora abrigasse as suas exposições no mesmo pavilhão da Bienal, o Museu foi gradualmente construindo um papel cada vez mais distante do circuito oficial, como espaço de resistência e acolhimento de práticas experimentais. Embora o MAC tenha aumentado a sua coleção de obras internacionais, principalmente adquiridas nas Bienais, quando a Reitoria da Universidade acendeu em propiciar verbas para esse fim (AMARAL, 1988, p. 37), foi a partir de outro tipo de colecionismo que o Museu se ajustou nesse período. O MAC estava ligado a uma ampla rede

\footnotetext{
${ }^{169}$ A ideia do museu como um laboratório experimental é descrita por Zanini no texto Problemas Museológicos, de 1964, no qual o historiador relata o encontro com diversos intelectuais na ocasião do ICOM - Conselho Internacional de Museus. Zanini manifesta interesse pelas ideias de Jean Cassou, o então diretor do Museu de Arte Moderna de Paris, citando algumas reflexões do francês: "O objetivo desse museu sendo o de conservar e classificar (característica do museu de um modo geral), é o de, sobretudo, ser um "laboratório experimental", de atividade presidida pelo "espírito de vida", pelo "estilo de presença e de presente". In: FREIRE, Cristina. [Org.]. Walter Zanini: Escrituras Críticas. São Paulo: Annablume: MAC USP, 2013.
} 
de artistas e instituições estrangeiras, das quais buscou estreitar laços durante toda a sua gestão. Dessa rede de contatos, o Museu pôde organizar grandes mostras internacionais como Prospectiva 74, de 1974, e Poéticas Visuais, de 1977, que analisaremos adiante. Para além do circuito hegemônico, essa rede estimulou intercâmbios com artistas e intelectuais que viviam em países sob regimes ditatoriais na América Latina e no Leste Europeu. Para essas duas exposições mencionadas, os artistas enviaram pela rede postal uma centena de obras experimentais resultantes nos novos media, como postais, mapas, fotografias, textos impressos, fotocópias, publicações, filmes, audiovisual etc. Grande parte desses trabalhos foi incorporada ao acervo do Museu.

Se deter em algumas dessas redes internacionais nos auxilia na compreensão dos pontos de convergência institucionais que envolviam a organização de exposições, a proximidade teórica por certos tipos de debate e reflexões da época e, especialmente, as possibilidades de trocas artísticas. Esse intercâmbio nos permite observar os micro-relatos por trás das distintas gestões institucionais. Seus inúmeros percursos são narrados por meio de correspondências que nos mostram eixos de afinidades, relações de amizade e confiança, a reciprocidade de interesses e a busca pelo diálogo.

Sabemos, por meio da análise dos documentos do arquivo do MAC USP, que a aproximação de Zanini com a Argentina foi iniciada ainda nos primeiros anos de sua gestão. O diretor do MAC demonstrou interesse em receber a exposição Prêmio Instituto Torcuato Di Tella, de 1964, organizada por Jorge Romero Brest e composta pelos jurados Clement Greenberg e Pierre Restany. Essa exposição ficou marcada pela dualidade artística dos jurados: de um lado, o defensor dos pressupostos modernistas, do outro, o promotor das novas vanguardas experimentais. E a grande premiada foi a artista Marta Minujín, com a ambientação de colchões retorcidos. É provável que Zanini tenha se interessado pela produção vanguardista apoiada pelo Di Tella, sobretudo, pelas experimentações de Minujín. Mais de uma década depois, a artista argentina iria apresentar a performance Repolhos no MAC USP, na ocasião da mostra Poéticas Visuais, em 1977. A performance fazia parte de uma fase denominada por Minujín de Arte Agrícola em Ação, cujo foco era trabalhar com materiais e emblemas típicos da cultura latino-americana. Em uma das salas do Museu, denominada Espaço B, a argentina espalhou cem sacos de repolhos e nesse local, vinte pessoas com um balde na cabeça participaram da ação cantando versos e ditando textos escritos pela artista. 


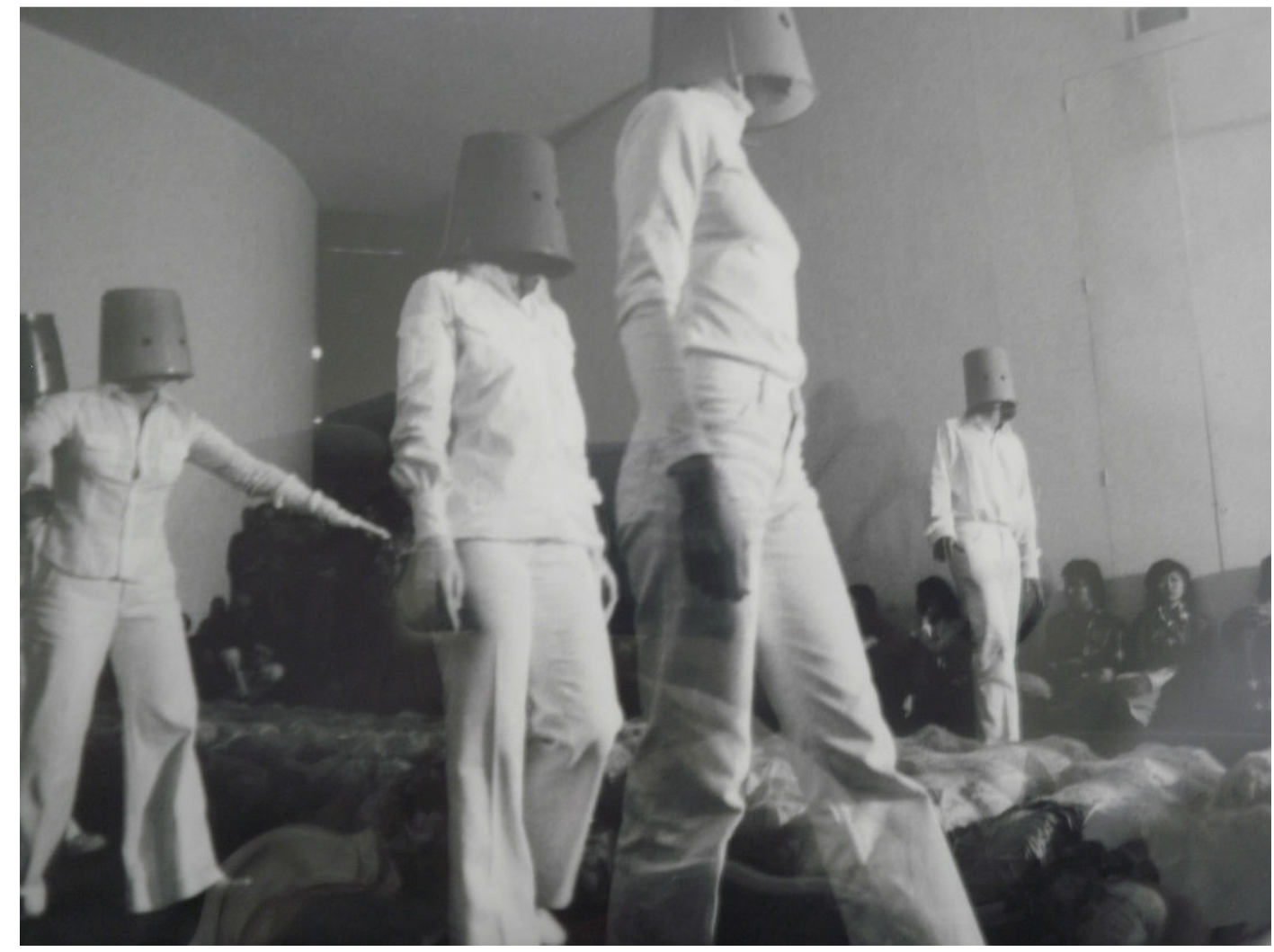

Figura 58 - Repolhos, Marta Minujín Performance no MAC USP, 1977

Zanini queria trazer ao MAC o Prêmio Nacional e Internacional daquele ano, mas, de acordo com Romero Brest, era impossível fazer a itinerância das obras internacionais, uma vez que o acordo entre o Di Tella e as instituições estrangeiras que cederam as obras, era que todas regressassem assim que acabasse a exposição em Buenos Aires. Desse modo, as negociações para apresentar o Prêmio Nacional Di Tella no MAC USP continuaram ao longo dos primeiros meses de 1965 e de acordo com Zanini, o Museu estava disposto a "colaborar ao máximo para o êxito da iniciativa que poderia marcar o começo do intercâmbio profícuo entre as duas entidades". ${ }^{170}$ Contudo, a tentativa de organizar essa mostra argentina no MAC não deu certo, por falta de apoio do Ministério das Relações Exteriores da Argentina.

\footnotetext{
${ }^{170}$ Correspondência de 13 abril 1965. Arquivo do Museu de Arte Contemporânea da Universidade de São Paulo.
} 


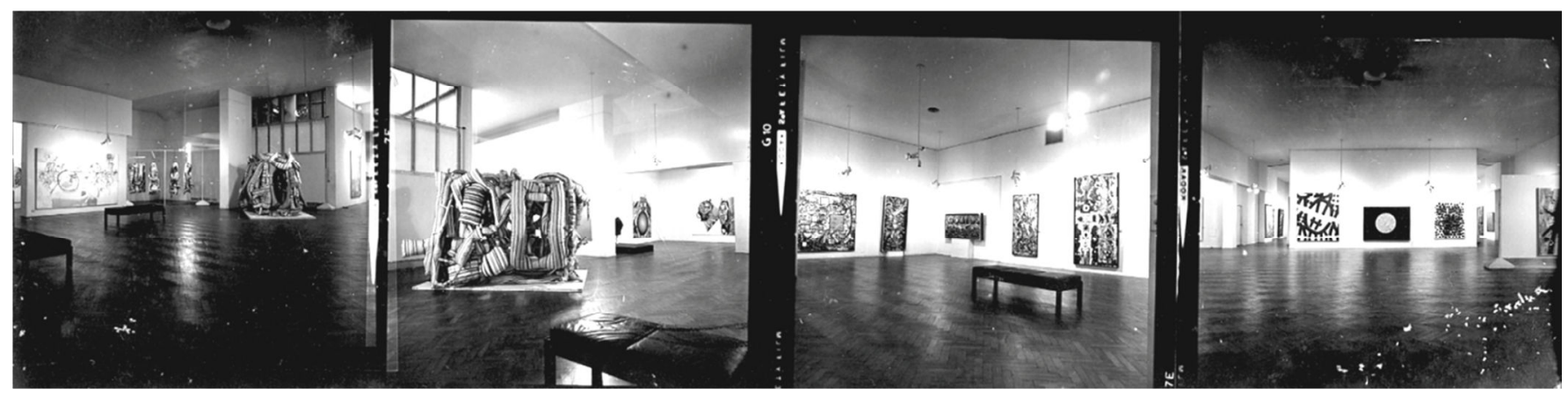

Figura 59 - Vista da exposição Prêmio Nacional Di Tella (detalhe), 1964 Arquivo Instituto Torcuato Di Tella

Mas é relevante notar o rumo das negociações e a maneira como deram prosseguimento durante esse ano, mesmo que nenhuma delas tenha se concretizado. E o ponto de confluência entre o MAC USP e o Di Tella foi a obra contemporânea de Marcel Duchamp. Zanini foi o primeiro a expor o projeto de organizar uma mostra de Duchamp no MAC e, segundo as cartas, desde o ano anterior estava em contato com a Galeria Schwarz, de Milão. E propunha aos vizinhos, caso demonstrassem interesse, a divisão das despesas que envolvia gastos com transporte, seguro, direitos autorais do catálogo raisonné etc., para efetivar a itinerância da mostra do artista francês em São Paulo e Buenos Aires. Romero Brest também estava em contato com a Galeria Schwarz e almejava trazer uma grande mostra de Duchamp ao Di Tella, mas as negociações não seguiram adiante. ${ }^{171}$

A influência duchampiana começou a ser disseminada ao longo da década de 1950, marcando assim, o legado fundamental do ready-made na produção contemporânea. Este deu todo o suporte teórico às práticas artísticas experimentais que se distanciavam cada vez mais da linguagem formalista e se rebelavam contra os modelos convencionais modernos. $\mathrm{O}$ aparecimento do ready-made era fruto direto da crise da pintura e "parecia mesmo ser o ponto terminal do debate acerca da "morte da pintura" preconizando "a redenção da arte enquanto Ideia” (CANONGIA, 2005, p. 16). Nesse sentido, o ready-made implicava uma operação sociocultural não mais focalizada na obra de arte em si, mas no conjunto das mediações entre dois sujeitos (o artista e o espectador), um objeto (ready-made) e um espaço (o museu) (ZABALA, 2012. p. 41).

O pensamento de Duchamp e sua contraoperação pictórica convergiam com as ideias que Zanini e Romero Brest desenvolveram, cada um a seu modo, em suas gestões.

\footnotetext{
${ }^{171}$ No caso brasileiro, só foi possível montar uma grande retrospectiva das obras de Duchamp na XIX Bienal, de 1987, com curadoria de Sheila Leirner.
} 
Especialmente, no distanciamento dos critérios pautados em categorias estéticas tradicionais, recriando suas práticas institucionais e abrindo espaço para o questionamento dos artistas em relação ao sistema de arte. A lógica do ready-made, ao transformar um objeto do cotidiano em obra de arte, acabava por deflagrar uma série de questionamentos nos espaços expositivos. Essa interferência possibilitou uma redefinição dos valores do sistema artístico e dos seus espaços institucionais, provocando nesses espaços novas potencialidades de criação.

Veremos adiante que a rede internacional de contatos agenciada por Zanini, desde o início de sua gestão, deu continuidade ao longo da década de 1970. Focaremos nosso recorte no intercâmbio promovido entre o MAC USP e CAYC.

\section{1 - DiÁlogos ENTRE GLUSBERg E ZANINI}

Podemos identificar pontos de contato estabelecidos por Walter Zanini em uma ampla rede internacional promovida desde 1963. Um deles foi com Jorge Glusberg, diretor do CAYC - Centro de Arte y Comunicación, de Buenos Aires. Essa rede contribuiu para sedimentar a expansão de "um território dialógico transnacional", que gerou diferentes experiências como o intercâmbio de artistas, exposições recebidas, convites para colóquios e, especialmente, a busca pelo diálogo "sensível ao problema cultural latino-americano". ${ }^{172}$

No começo da década de 1970, Zanini estava organizando as JACs e ao mesmo tempo problematizando o papel do museu de arte contemporânea e a necessidade da revisão de sua função, além da adaptação às exigências das novas linguagens artísticas. $\mathrm{O}$ crescimento dos recursos de comunicação de massa e das obras resultantes da utilização desses novos media propunham um novo desafio ao museu para repensar os seus espaços além da unicidade do objeto permanente. No texto Os museus e o novos meios de comunicação, de 1976, Zanini refletia sobre o aumento dos meios tecnológicos de comunicação entre os artistas e, como consequência, um interesse maior na participação da realidade social. O fenômeno das correntes conceituais havia deflagrado uma postura crítica diante da mística da obra única e suas implicações estéticas e econômicas, ampliando o circuito habitual composto pelo museu, galeria e colecionador. "As técnicas operativas de uma arte que exige equipamentos

\footnotetext{
172 Correspondência de Walter Zanini a Jorge Glusberg. 28 mar 1972. Arquivo do Museu de Arte Contemporânea da Universidade de São Paulo.
} 
eletrônicos, por sua vez, introduzem modificações em um espaço, cuja destinação sempre fora a da quase exclusiva apresentação de objetos estáticos" (ZANINI, 1976), gerando ao museu um processo contínuo de reavaliação, confrontação e desenvolvimento desses processos de produção.

Por sua vez, nesse mesmo período, Glusberg estava buscando estratégias de divulgação e consolidação das correntes teóricas e artísticas desenvolvidas no CAYC. Sua linha de interesse, focada nas práticas interdisciplinares, tinha como objetivo a criação de circuitos de visibilidade local e internacional para a promoção de artistas argentinos contemporâneos (MARCHESI, 2012, p. 591). Com base na cibernética e nas teorias da informação, foi delineando o conceito de sistema que amparou as primeiras mostras organizadas pelo Centro, como Arte de Sistemas. Associado às práticas conceituais em voga nos circuitos internacionais hegemônicos, Glusberg estruturou um eixo discursivo regional, inserindo os conceitualismos a uma retórica latino-americanista. Desse modo, uma teoria das ideologias artísticas deveria se ajustar às reais condições sociais e econômicas locais, criando uma dialética entre "simbologías importadas y simbologías propias" capazes de desenvolver a reprodução de ideologias artísticas nas comunidades locais (GLUSBERG, 1985, p. 54). Na mostra Art Systems in Latinamerica ${ }^{173}$, fruto da ambiciosa campanha de internacionalização da arte argentina por meio de contatos com o circuito europeu, Glusberg escreveu:

Podemos señalar una diferencia fundamental: los europeus hacen una discusión teórica de los problemas políticos, y los latinoamericanos los incluyen obligadamente en sus obras, por vivir esos problemas políticos a nível cotidiano. En esta etapa podríamos decir que más que obras, los operadores de arte latinoamericano producen documentos comprometidos con su realidad, constâncias de lo que está ocurriendo en sus respectivos países. ${ }^{174}$

Como vimos, a categoria arte de sistemas e suas implicações regionais moldaram o discurso institucional, buscando um diferencial na produção local. O CAYC também privilegiou os novos meios de comunicação como a televisão e o vídeo como ferramenta artística, alinhadas às práticas conceituais. Glusberg encarava os mass media não como meios técnicos, mas como operadores ideológicos, como lugares privilegiados das manifestações de

\footnotetext{
${ }^{173}$ Mostra no Institute of Contemporany Arts, Londres, 1974.

174 "Podemos sinalizar uma diferença fundamental: os europeus fazem uma discussão teórica dos problemas políticos, e os latino-americanos o inclui obrigatoriamente em suas obras, por viverem esses problemas políticos a nível cotidiano. Nesta etapa poderíamos dizer que mais do que as obras, os operadores de arte latino-americano produzem documentos comprometidos com a sua realidade, sobre o que está ocorrendo em seus respectivos países." (tradução nossa).
} 
significação social. Seguindo a mesma série discursiva ajustada a um recorte local, o vídeo também seria a materialização das relações sociais e uma fonte de implicações ideológicas. Desde 1973, o CAYC explorou o terreno do cinema experimental, por meio da Cooperativa Ediciones del Tercer Mundo, integrada por Danilo Galasse, Pedro Roth e o próprio Glusberg. A programação incluía desde a realização de filmes e videotapes à formação de uma videoteca de artistas de diversos países latino-americanos. No contexto paulistano, Zanini criou um convênio com a Associação dos Amigos da Cinemateca com o intuito de organizar programações de cinema e exposições relacionadas ao tema. Mas o mais relevante foi o impulso que o MAC deu à difusão da videoarte. O aparelho portátil Sony Portapak de vídeo tinha sido recentemente lançado no mercado e Zanini buscou recursos para adquirir o equipamento, que foi colocado à disposição dos artistas, em 1976. Sempre atento à ampliação do papel dos museus, o diretor do MAC refletia sobre o vídeo em "termos de expressão e em seus potenciais educacionais, e de informação" como perspectiva para a saída da "crise do estado atual da arte que atinge os museus" (ZANINI, 1975). ${ }^{175}$

É provável que todo esse pensamento que visou problematizar o novo lugar da arte, em um momento de ruptura dos suportes tradicionais, da crítica ao sistema oficial artístico, a inserção da comunicação de massa e do cotidiano, bem como a desmaterialização do objeto artístico, tenha aproximado Zanini e Glusberg. Na mesma época, surgiu na Europa um circuito contemporâneo de novos espaços e centros culturais, impulsionados por políticas culturais e, sem dúvida, o CAYC, em uma escala mais modesta, procurou reproduzir esse modelo (MARCHESI, 2012, p. 596). No contexto sul-americano, buscou atualizar os projetos mais contemporâneos desse circuito hegemônico, sedimentando-se como espaço alternativo no âmbito local.

Já Zanini, dialogando dentro de uma ampla rede internacional, buscou atualizar as novas demandas teóricas e artísticas, tendo como ponto de partida o papel social de um museu de arte contemporânea inserido no contexto universitário. Junto aos artistas, organizou exposições que buscavam estimular o uso do museu para o desenvolvimento de projetos, cursos, palestras e como fórum de debates (FREIRE, 2006, p. 27), distante da lógica hegemônica dos grandes circuitos artísticos. O crítico de arte Roberto Pontual publicou uma matéria na época da inauguração da mostra Prospectiva 74, no MAC USP, na qual refletia

\footnotetext{
${ }^{175}$ Versão original do artigo $A$ videoarte no seu limiar, publicado no jornal O Estado de S. Paulo, em 1975. In: FREIRE, Cristina. (Org.). Walter Zanini: Escrituras Críticas. São Paulo: Annablume: MAC USP, 2013.
} 
sobre as exposições de caráter experimental no Museu, desde as JACs até a manifestação internacional de arte postal, ressaltando o papel quase visionário de Zanini no país.

Não se pode negar ao MAC USP um esforço continuado de renovação, nos últimos 12 anos, dos esquemas que têm regido as mostras coletivas no Brasil. Concentrando-se na arte jovem, o MAC decidiu desde logo levantá-la e documentá-la por vias criadoramente didáticas, substituindo o velho sistema de exposições com uma ampla abrangência por uma compartimentação funcional dos setores de atividade, ao mesmo tempo em que, através de aquisições, garanta o acervo que o torna quase único no campo da arte brasileira contemporânea. ${ }^{176}$

Tanto o MAC USP quanto o CAYC tornaram-se pontos referenciais das práticas experimentais no continente sul-americano, compartilhando um perfil de locais abertos para a realização de proposições de caráter mais conceitual e muitas vezes considerados subversivos, em um contexto marcado pela repressão. As duas instituições partilharam projetos semelhantes, conectando-se para receber artistas estrangeiros que faziam itinerância pela região. Podemos citar os artistas do Coletivo de Arte Sociológica, composto por Hervé Fischer, Jean-Paul Thénot e Fred Forest, que passaram pelo MAC USP em 1975, com as mostras Arte e Comunicação Marginal - Carimbos de Artistas; Exposição Coletiva do Grupo de Arte Sociológica de Paris; Farmácia Fischer \& Cia e Bienal do ano 2000. Esse Coletivo surgiu em 1974, na esteira das ações artísticas que buscavam uma relação mais crítica entre a arte, seus circuitos de distribuição e suas representações ideológicas. Os três artistas franceses publicaram no jornal Le Monde, nesse mesmo ano, o primeiro manifesto da arte sociológica, exaltando como eixo fundamental o fato sociológico da prática artística apoiado na relação inseparável entre arte e sociedade e vida. Contudo, essa arte sociológica não deveria ser confundida com a sociologia da arte ou um tipo de arte social comprometida, como a pintura militante, caracterizada por "formalismos estéticos" e "clichês pictóricos". A arte sociológica se fundamentava nos métodos das ciências sociais para pôr em prática as suas ações artísticas enquanto campo privilegiado de investigação para a teoria sociológica.

Nós definimos a arte sociológica pela sua relação epistemológica necessária com a ciência sociológica. Essa relação é dialética. Ela funda a prática artística que a experimenta e recebe em contrapartida a objeção da força do real social. Essa relação é específica da arte sociológica: distingue-a de todos os outros processos tradicionais ou vanguardistas. Tal relação significa, ao contrário da expressão tradicional da arte como ideologia mistificadora do

\footnotetext{
${ }^{176}$ Entre o atrás e o adiante. Jornal do Brasil. 28 ago. 1974. Arquivo do Museu de Arte Contemporânea da Universidade de São Paulo.
} 
irracional, a vontade de recorrer ao discurso científico da sociologia e confrontar a nossa prática à racionalidade desse discurso. ${ }^{177}$

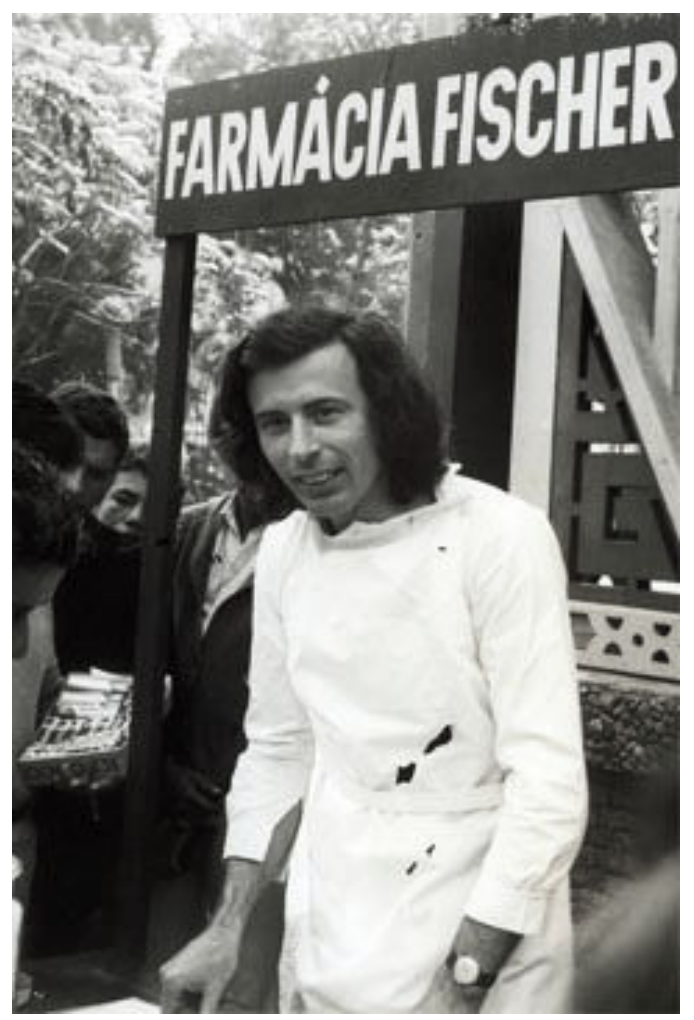

Figura 60 - Farmácia Fischer \& Cia, Hervé Fischer, 1976

A convite de Walter Zanini, Hervé Fischer realizou a Farmácia Fischer \& Cia na praça da República, em plena ditadura militar. Vestido como um farmacêutico e junto aos vendedores ambulantes do centro de São Paulo, o artista propôs uma série de reflexões aos transeuntes. Tendo como referência a metodologia das ciências sociais e a possibilidade direta de comunicação com o público, Fischer conversou, ouviu histórias e receitou pílulas para diversos fins: mudar de ideia, pensar, liberdade, ser criativo etc. Eram pílulas de poliuretano embaladas em pequenos sacos com a frase “A vida está nas pílulas!”. Como a ação era espontânea, o artista não imaginou que fosse juntar tanta gente a sua volta, e como eram tempos de repressão, qualquer manifestação que reunisse um grupo maior de pessoas era considerada um ato suspeito. Para dispersar aquele grupo de transeuntes e por falta de

177 Segundo Manifesto, originalmente publicado no catálogo da Galliera Museum (Paris), para a mostra do Coletivo de Arte Sociológica, 1974. In: FREIRE, Cristina. (Org.). Hervé Fischer no MAC USP: arte sociológica e conexões: arte-sociedade-arte-vida. São Paulo: Museu de Arte Contemporânea da Universidade de São Paulo, 2012. 
autorização da prefeitura para realizar aquela ação, os policiais proibiram a continuação da proposta de Fischer. ${ }^{178}$

Em uma das correspondências trocadas nessa época, Zanini e Glusberg dialogaram sobre a vinda de Hervé Fischer à América do Sul e a possibilidade de encontrar meios para a divisão das despesas. A vinda do francês, assim como dos outros membros do Coletivo de Arte Sociológica ao MAC e ao CAYC, atesta o elo de afinidades propositivas das duas instituições, além da conexão de ambas com o que era produzido de mais atual e potente no terreno das artes e do pensamento em circulação em distintos canais na Europa.

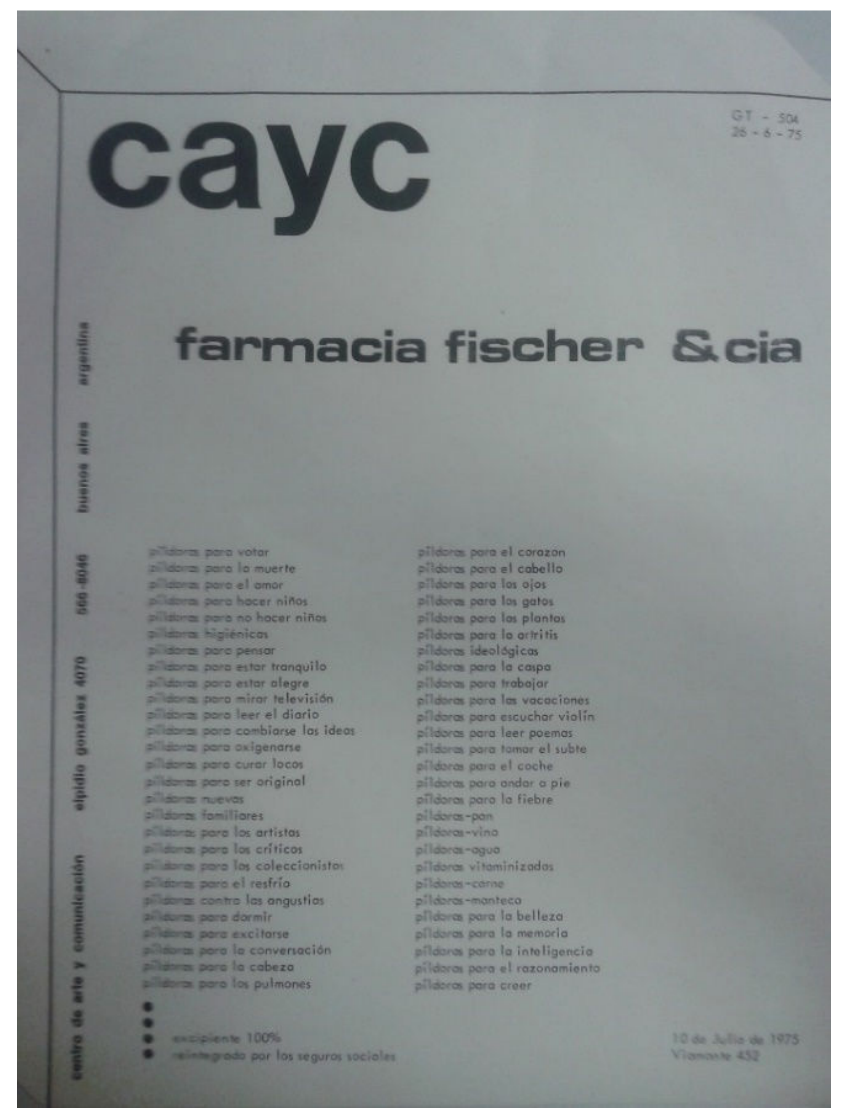

Figura 61 - Gacetilla GT 26-06-75, Farmacia Fischer \& Cia, 1975 Biblioteca Lourival Gomes Machado

Hervé Fischer ainda participaria da mostra Papel y Lapiz, organizada pelo colombiano Jonier Marin, em parceria entre o CAYC, o MAC USP e o Museu de Arte Moderna de Bogotá, em 1976. Cada artista deveria enviar um desenho e uma foto de si mesmo, ambos em xerox. A exposição ocorreu simultaneamente nos três países, focada no circuito de comunicação estabelecido entre os artistas, o organizador e as instituições participantes.

${ }^{178}$ Farmácia Fischer \& Cia. In: FREIRE, Cristina. (Org.). Hervé Fischer no MAC USP: arte sociológica e conexões: arte-sociedade-arte-vida. São Paulo: Museu de Arte Contemporânea da Universidade de São Paulo, 2012. 
Participou também da mostra de heliografias Década de 70, organizada pelo CAYC e que fez itinerância em Buenos Aires, São Paulo e Cidade do México, entre 1976 e 1977. Os artistas argentinos ligados ao Grupo de los Trece também estariam presentes nas duas mostras.
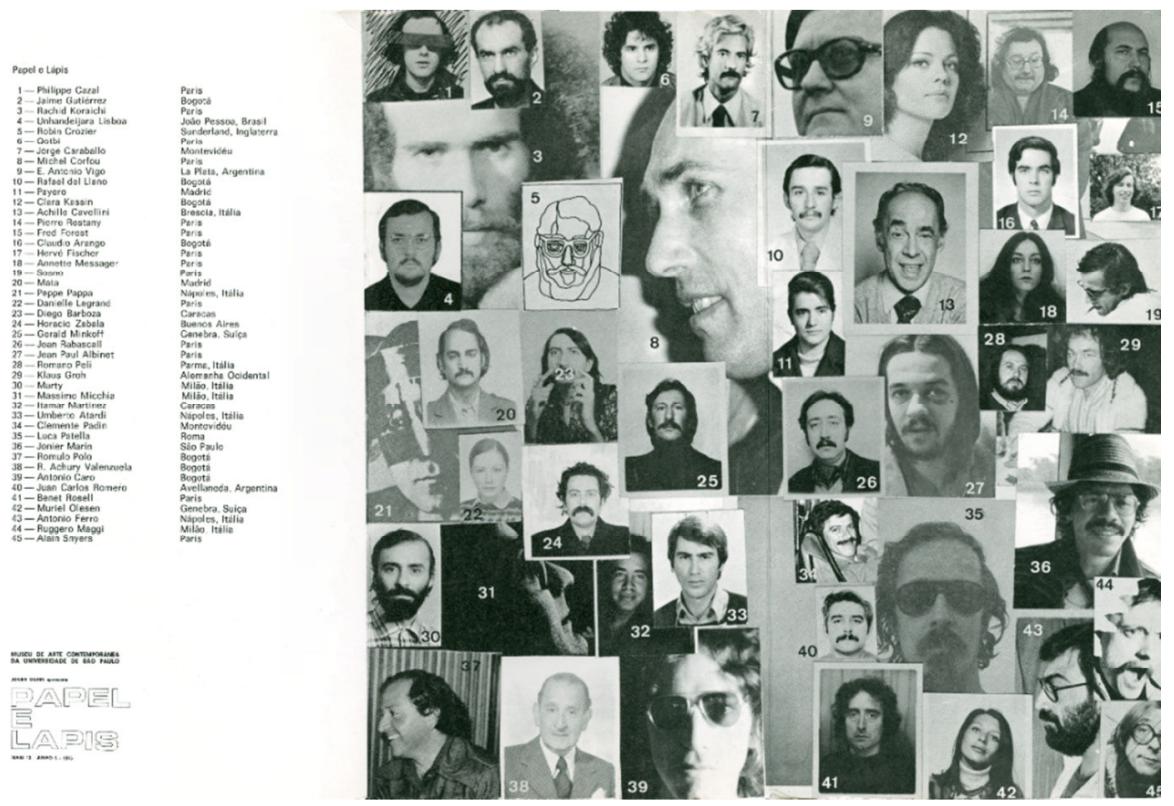

Figura 62 - Catálogo da mostra Papel e Lápis, 1976, MAC USP

Biblioteca Lourival Gomes Machado

Em 1974, Glusberg escreveu a Zanini oferecendo uma mostra do artista Fluxus Dick Higgins: "Tenemos una muestra de serigrafias originales de Dick Higgins, las cuales podemos ofrecerle a un bajo costo ya que estas están sin enmarcar. Solamente habría que pagar el flete de Buenos Aires a San Pablo". ${ }^{179}$ Nesse mesmo ano, o CAYC havia organizado uma exposição de Higgins e divulgado, via gacetillas amarillas, um texto do artista publicado por sua editora, The Something Else Press, intitulado Visto, Oido y Comprendido.

Quiero defender la literatura. Es un arte del hombre pobre. Usted puede pensar, aunque no se sienta cómodo entre los príncipes con cigarro y las venerables patituertas en minifaldas que aparecen en nuestra escena de las artes visuales. [...] Las artes plásticas están corruptas: esto es un lugar común, y se mueve por este o aquel "look", como el dinero está de moda, por tanto el arte está de moda, y se mueve por este o aquel "look", como el diseño de ropa. ${ }^{180}$

\footnotetext{
179 "Temos uma mostra de serigrafias originais de Dick Higgins, das quais podemos oferecer-lhe a um baixo custo, uma vez que estas estão sem moldura. Somente havia que pagar o frete de Buenos Aires a São Paulo." (tradução nossa). Correspondência de Jorge Glusberg a Walter Zanini. 28 out. 1974. Arquivo do Museu de Arte Contemporânea da Universidade de São Paulo

180 "Quero defender a literatura. É a arte de um homem pobre. Você pode pensar, embora não se sinta confortável entre os príncipes com charuto e jovenzinhas veneráveis em minissaias que aparecem em nossa cena de artes visuais. [... ] As artes plástica estão corruptas: isto é um lugar comum que se move por este ou aquele
} 
The Something Else Press foi a editora fundada por Dick Higgins, onde desenvolveu atividade crítica paralelamente ao exercício artístico, em uma época que se multiplicaram editoras alternativas de publicação e livros de artistas. Essas editoras eram resultado da postura de diversos artistas que reagiram contra a centralização dos canais de comunicação, produção e distribuição de arte e literatura, promovendo uma democratização dos meios de reprodução.

Zanini, que já tinha contato com o artista Fluxus, aceitou a proposta de Glusberg. Inclusive, o MAC USP possuía obras de Higgins em seu acervo desde o início da década de 1970, sendo a maior parte adquirida por meio do envio postal. ${ }^{181}$ O Museu organizou a exposição individual do artista, Em torno de 7.7.73, em 1976. Era composta por 50 serigrafias resultantes da vivência do artista na cidade de West Glover, nos EUA, além de alguns de seus livros ligados à poesia visual. Como atividade paralela, Higgins apresentou uma conferência sobre o artista John Cage. Walter Zanini, três décadas depois, publicou um artigo sobre a atualidade e o legado dos trabalhos Fluxus: "era uma arte feita de simplicidade, antiintelectual, que desfizesse a distância entre o artista e o não artista, uma arte em estrita conexão com a normalidade da vida e segundo princípios coletivos e finalidades visceralmente sociais". ${ }^{182}$

Outro artista que fez itinerância pela América do Sul (Brasil, Uruguai, Paraguai e Argentina), em 1976, foi Isidoro Valcárcel Medina, um dos pioneiros das práticas conceituais na Espanha. Mais uma vez, o MAC USP e o CAYC conformaram-se como lugares possíveis de acolhimento e como promotores da vanguarda internacional, fincando-se como ponto de passagem nessa cartografia formada por instituições de caráter experimental. A partir da vivência nos quatro países do Cone Sul, o espanhol produziu um relatório de viagem, relatando criticamente a experiência em cada cidade, intitulado Informe y resumen general de actividades en Sudamerica. O interesse despertado pelas práticas artistas latino-americanas se deu por sua posição marginal e fora do circuito hegemônico, além de o artista partilhar a mesma realidade de viver sob um regime ditatorial.

\footnotetext{
"look", como o dinheiro está na moda, então a arte está na moda, e se move por este ou aquele "look" como o desenho de roupas." (tradução nossa). Gacetilla GT - 09-08-74. Dick Higgins. The something else newsletter, v. 2, n. 5. Arquivo Fundación Espigas.

${ }^{181}$ Sobre a presença de Dick Higgins e outros artistas Fluxus no Museu, ver: SCHNEIDER, Emanuelle. InFluxus: Ressonâncias Fluxus no acervo do MAC USP. Dissertação de Mestrado. Programa de PósGraduação Interunidades em Estética e História da Arte, Universidade de São Paulo, São Paulo, 2011.

${ }^{182}$ A atualidade Fluxus. Ars, São Paulo, v.2, n. 3, p. 10-21, 2004. In: FREIRE, Cristina. (Org.). Walter Zanini: Escrituras Críticas. São Paulo: Annablume: MAC USP, 2013.
} 
No processo de sua vinda, Zanini escrevera: "Caro Glusberg, em primeiro lugar, muito obrigada a você pela incessante remessa de páginas amarelas, diapositivos, comunicados etc. [...] Válcarcel quer vir a São Paulo. Estamos tentando achar um jeito"183. Em resposta, o argentino confirmou: "Válcarcel Medina vendrá a Buenos Aires. No tenemos ningún problema si ud. realiza alguna exposición com él antes o después de su trabajo aquí. Le hemos dicho que se ponga en contacto con él pues nos parece una persona interesante". ${ }^{184} \mathrm{O}$ artista espanhol, por meio da rede de arte postal, havia passado pelo MAC USP, na ocasião da mostra Prospectiva 74 e posteriormente iria participar, enviando trabalhos para as exposições Década de 70, organizada por Glusberg, e Poéticas Visuais.

No CAYC, Medina fez uma exposição individual na qual reuniu diversos registros de ações artísticas. Uma delas foi realizada no Paraguai, local por onde o artista havia passado antes de chegar em Buenos Aires. 136 Manzanas de Assunción tratava-se de um percorrido pelas ruas da capital, onde o artista abordava aleatoriamente transeuntes e pedia que o levassem para caminhar em algum quarteirão. Nessa caminhada, o artista recolhia informações sobre o bairro, sobre o acompanhante e outros dados sobre a cidade e o país, resultando em uma ampla documentação sociológica sobre o lugar visitado. Uma outra ação que seria realizada pelo artista, não pôde ser exposta devido ao seu conteúdo político explícito. Consistia em uma obra que o artista havia trazido consigo, na qual pedia para as pessoas assinarem o nome do presidente Salvador Allende em uma grande folha de papel. A ideia inicial era que a obra original ou suas cópias continuassem circulando e recebendo novas assinaturas. $\mathrm{O}$ artista foi aconselhado a destruir a cópia levada a Buenos Aires, a fim de evitar qualquer problema com a censura. ${ }^{185}$ Contudo, uma versão desse trabalho foi preservada e posteriormente enviada para participar da mostra Poéticas Visuais, em 1977, no MAC USP. Vale lembrar que o CAYC havia organizado, em 1973, uma mostra em homenagem ao presidente deposto Salvador Allende, "líder de América lamentablemente desaparecido", com a exibição de trabalhos de artistas contemporâneos chilenos. Entretanto, na ocasião da ação proposta por Válcarcel Medina, a situação política do país era cada vez mais instável, em

\footnotetext{
183 Correspondência de Walter Zanini a Jorge Glusberg. 05 mar.1976. Arquivo do Museu de Arte Contemporânea da Universidade de São Paulo.

184 "Válcarcel Medina virá a Buenos Aires. Não temos nenhum problema se você realizar alguma exposição com ele antes ou depois de seu trabalho aqui. Temos dito que entre em contato com ele, pois nos parece uma pessoa interessante." (Tradução nossa). Correspondência de Walter Zanini a Jorge Glusberg. 23 mar. 1976. Arquivo do Museu de Arte Contemporânea da Universidade de São Paulo

${ }^{185}$ Roteiro de Viagem de Isidoro Valcárcel Medina pela América do Sul. In: FREIRE, Cristina. (Org.). A cidade e o estrangeiro: Isidoro Valcarcel Medina. São Paulo: Museu de Arte Contemporânea da Universidade de São Paulo, 2012.
} 
decorrência do golpe de Estado dominado pelo general Jorge Videla, em 1976. Seu regime ditatorial foi um dos mais sangrentos da América Latina, marcado pelo desaparecimento de milhares de prisioneiros políticos.

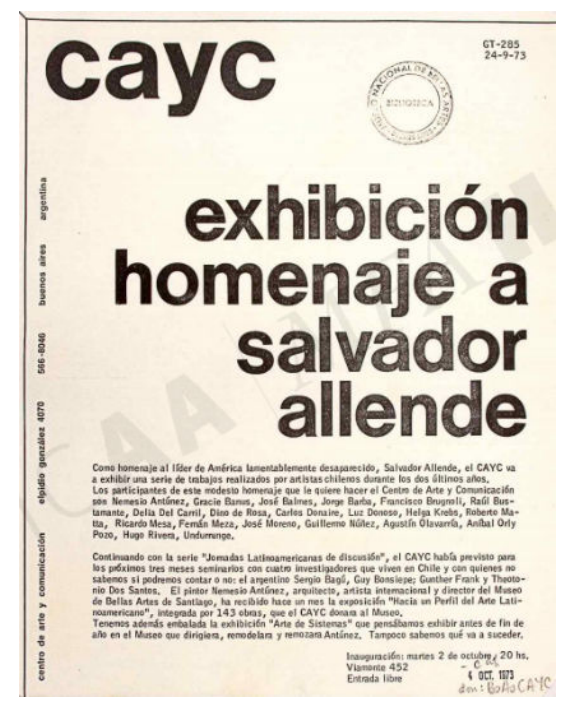

Figura 63 - Gacetilla GT 24-09-73. Exhibición homenaje a Salvador Allende, 1973

ICCA - Documents of 20th-century Latin American and Latino Art

No MAC USP, Medina realizou a mostra individual A Cidade e o Estrangeiro: Três Exercícios de Aproximação, em 1976, cuja relação dos temas cidade (São Paulo) e a vivência de ser estrangeiro (o artista espanhol), se entrelaçavam de forma irônica por meio da noção de indivíduo e dos limites da linguagem. Em uma das ações, Dicionário de la Gente, Medina distribuiu aos transeuntes um cartão com a seguinte informação: "Sou um artista estrangeiro em visita ao Brasil. Nada sei de português e ficar-lhe-ei muito grato se me escrevesse nesse cartão uma palavra qualquer do seu idioma”. As palavras e frases escritas em cartões foram recolhidas e expostas no MAC USP: amor, bem-vindo, contemporâneo, liberdade, arte é vida, o importante é que nossa emoção sobreviva etc. ${ }^{186}$ Em seguida, o artista organizou um dicionário com todas as palavras coletadas nessa experiência em São Paulo. Já na obra Hombres Anuncio, Medina propunha estratégia semelhante às práticas publicitárias de venda de produtos e serviços para divulgar uma "arte ambulante" pelas ruas de Madri. O registro fotográfico também foi enviado para a exposição no MAC USP.

${ }^{186}$ Roteiro de Vviagem de Isidoro Valcárcel Medina pela América do Sul. In: FREIRE, Cristina. (Org.). A cidade e o estrangeiro: Isidoro Valcarcel Medina. São Paulo: Museu de Arte Contemporânea da Universidade de São Paulo, 2012. 


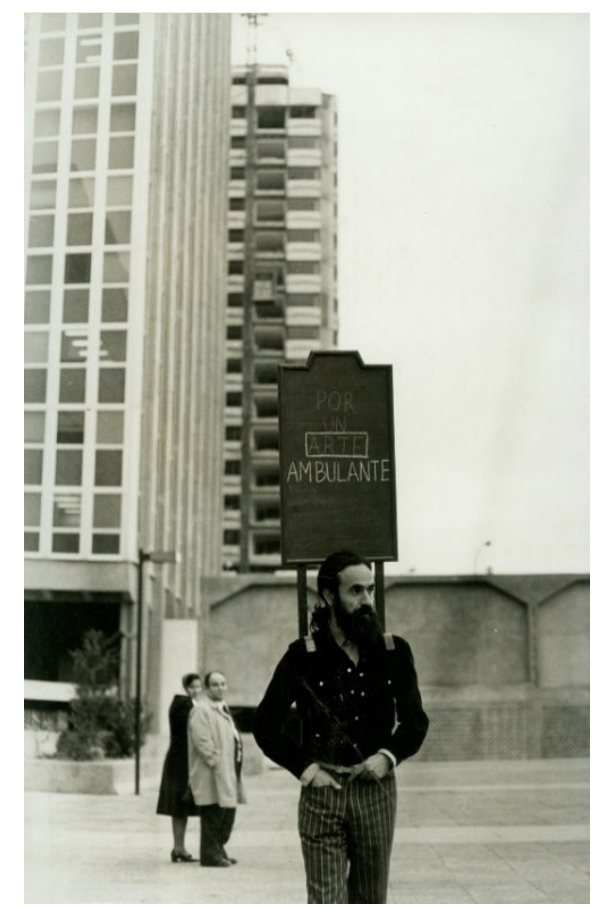

Figura 64 - Hombres Anuncio, Isidoro Válcarcel Medina, 1976

A passagem desses artistas estrangeiros pelo MAC USP e CAYC atesta a importância dessas entidades como polos de criação e territórios possíveis de liberdade e experimentação no cone sul. Vários artistas brasileiros também passaram pelo CAYC, muitos deles por indicação de Walter Zanini. Podemos citar as mostras de Julio Plaza, Regina Silveira, Regina Vater, Ângelo de Aquino e Gastão de Magalhães.

A crítica e historiadora de arte Aracy Amaral também foi interlocutora de Jorge Glusberg nesse período, levando duas exposições ao CAYC. Uma delas foi EXPOPROJEÇÃO 73 - Proyección de films y audiovisuales brasileños. Aracy organizou e coordenou essa mostra composta por filmes e audiovisuais, em colaboração com o Grupo de Realizadores Independentes de Filmes Experimentais do Brasil. Era uma apresentação coletiva de novas formas de expressão artística com a presença de diversos artistas contemporâneos brasileiros. Ao final, a crítica foi convidada por Glusberg para realizar uma conferência sobre os filmes experimentais expostos. Participaram: Frederico Morais, Cildo Meireles, Gabriel Borba, Antonio Dias, Lygia Pape, Donato Ferrari, Antonio Manuel e outros. Essa mostra foi um importante marco histórico, ao reunir boa parte das realizações em filmes, audiovisual com slides e obras sonoras, ainda em 1973. Antes de ir para o CAYC, EXPOPROJEÇÃO 73 foi exibida em São Paulo, em um espaço alternativo aos circuitos de museus e galerias chamado GRIFE. No catálogo da mostra, Aracy escreveu: 
EXPOPROJEÇÃO 73 é uma manifestação porque é uma apresentação pública entre nós de formas novas de expressão artística, coletivamente. Neste bloqueio permanente pela informação, ocorrem outras formas de expressão, simultaneamente, todas válidas e vivas, mas acredito que seja importante continuamente checar quais as mais recentes e registrá-las. Não com o intuito de rotulação - o que seria irrelevante - mas a fim de mostrar que a criatividade, apesar de quaisquer pressões, é sensível à ativação provocada pela realidade ambiental. E tentar ver o gesto criativo traz sempre a possibilidade de diagnosticar o estado de saúde dessa mesma realidade. ${ }^{187}$

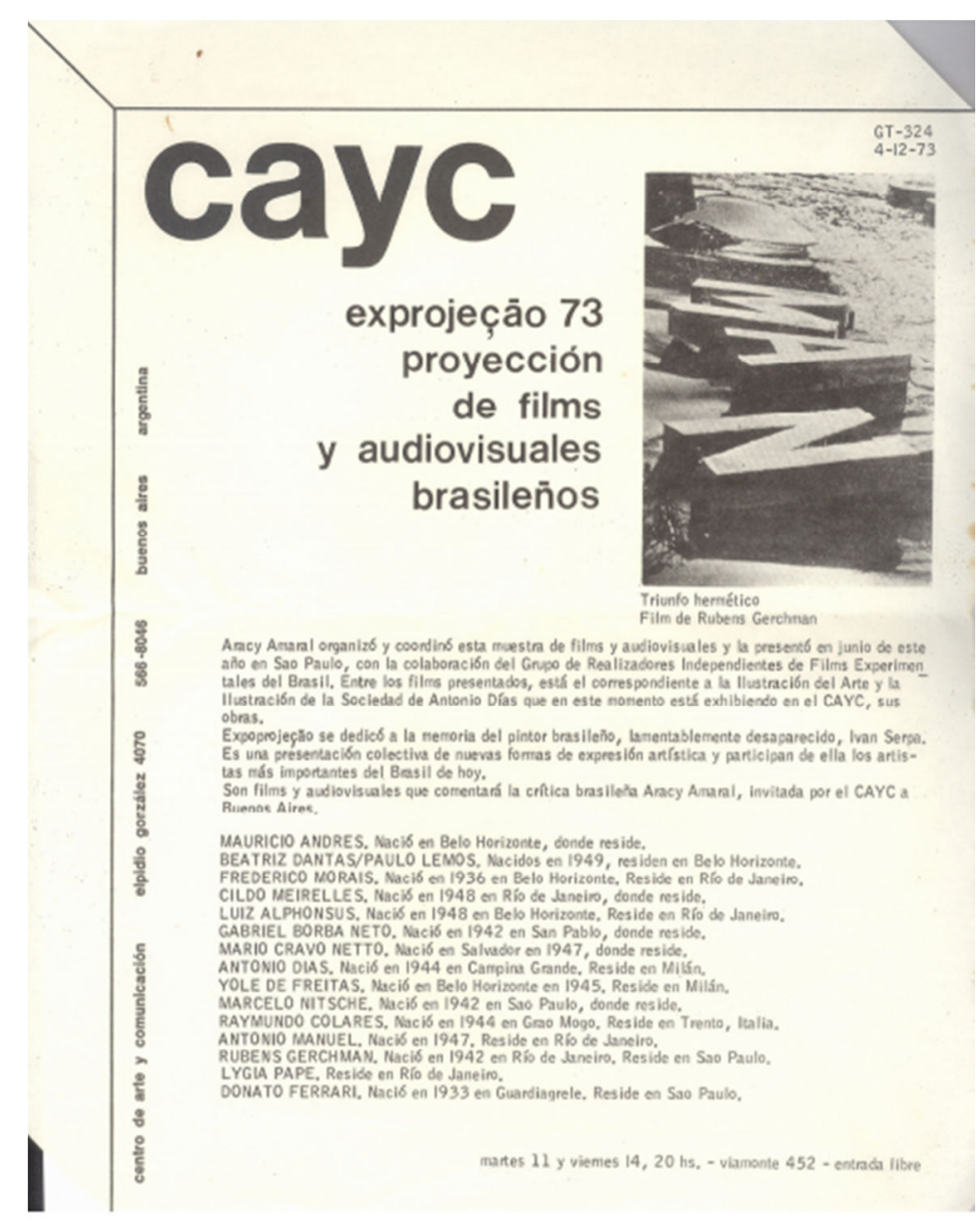

Figura 65 - Gacetilla GT 04-12-73. Exprojeção 73, 1973

Arquivo MAC USP

187 Compilação do texto de curadoria e depoimentos dos artistas, publicados no catálogo original da Expoprojeção 73. AMARAL, Aracy. In: http://expoprojecao.com.br/_pdf/expo_catalogo.pdf. Acesso em: 20 jul. 2015. 
No ano seguinte, Aracy Amaral e Glusberg organizaram a mostra Vanguardia Brasileña 74, com aproximadamente 70 trabalhos de jovens artistas brasileiros das "tendencias más características del arte plástico brasileño actual: arte ecológico, arte pobre, arte de acción y arte mágico"188, entre eles, Lygia Papel, Genilson Soares, Francisco Inarra, Cildo Meireles etc.

A passagem de artistas e intelectuais brasileiros pelo CAYC, fazia parte do programa institucional de apoio e divulgação da arte latino-americana no âmbito local, por meio de um fértil intercâmbio artístico. Contudo, a ponta de lança da instituição era promover e circular a produção argentina, sobretudo, o Grupo de los Trece, por entidades estrangeiras, dando visibilidade e legitimidade aos artistas ligados à arte de sistemas. Como vimos, Glusberg sedimentou diversas estratégias para internacionalizar o discurso artístico regionalista: desde a fácil circulação de obras, por meio do suporte heliográfico, à integração de códigos conceituais pelo modelo denominado arte de sistemas. Parte da historiografia da arte $\operatorname{argentina~}^{189}$ que pesquisa o CAYC e a direção de Jorge Glusberg, mapeou e investigou muitas das mostras organizadas pelo Centro que fizeram itinerância pelo os EUA e a Europa. ${ }^{190}$ Contudo, pouco foi investigado sobre o intercâmbio que o diretor argentino promoveu com instituições vizinhas, como é o caso do MAC USP.

\footnotetext{
188 “Tendências mais características das artes plásticas brasileiras atuais: arte ecológica, arte pobre, arte de ação e arte mágica." (tradução nossa).

${ }^{189}$ Ver: Maria José Herrera, Mariana Marchesi, Natalia Pineau, Fernando Davis e Graciela Sarti.

190 Camden Arts Centre e Institute of Contemporary Arts, em Londres; Internationaal Cultureel Centrum, de Amberes; Espace Cardin e Centre National dÁrt et de Culture Georges Pompidou, em Paris; Universidade de Minnesota, em Minesota; Encuentros de Pamplona, em Pamplona; MoMA, em Nova Iorque, além da itinerância por vários países do leste europeu.
} 


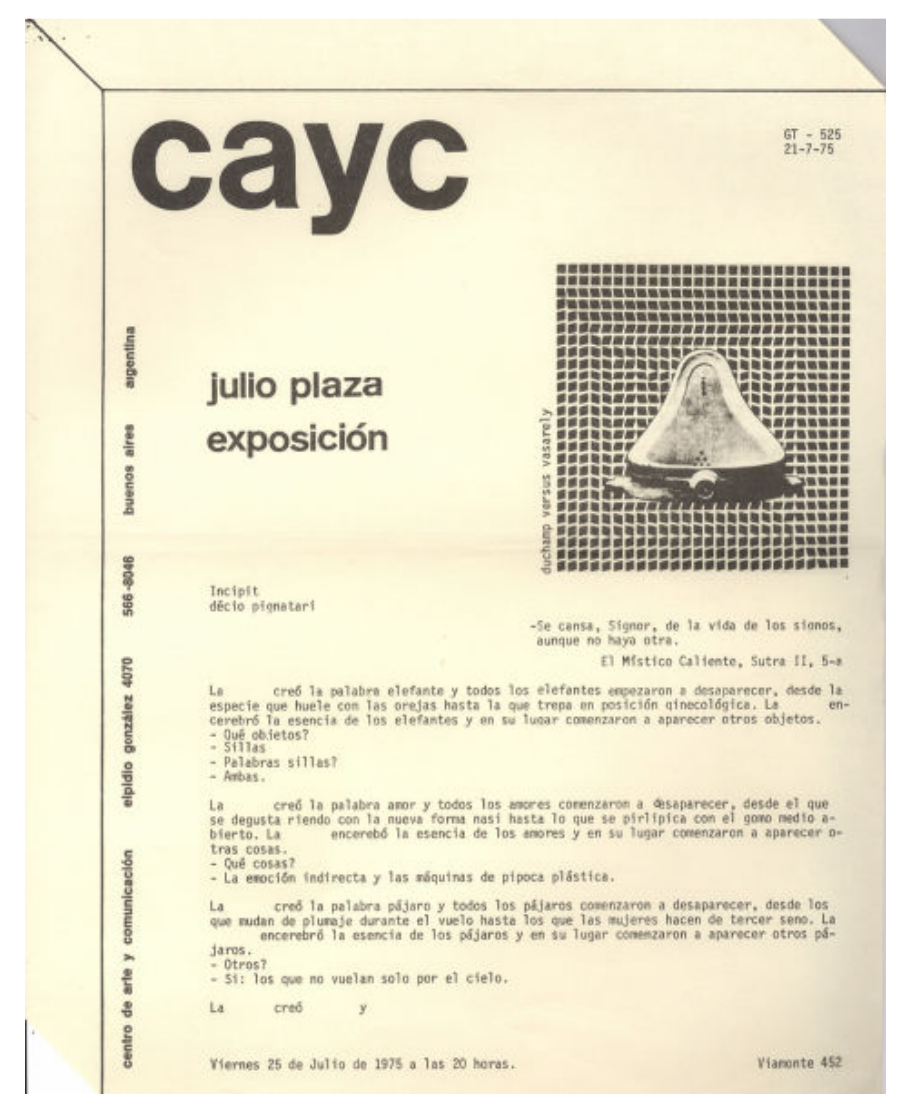

Figura 66 - Gacetilla GT 27-07-75. Julio Plaza exposición, 1975 Arquivo MAC USP

Desde as primeiras correspondências trocadas entre Zanini e Glusberg, em 1972, o diretor argentino buscou negociar a itinerância das mostras organizadas pelo CAYC para serem exibidas no MAC USP. Segundo as cartas do arquivo, Glusberg aproveitou a ocasião da exposição de Aracy Amaral para negociar a vinda de Hacia un Perfil de Arte latinoamericano para São Paulo, entretanto, o perfil político de diversas obras poderia dificultar o trâmite da mostra.

"Estimado Zanini, aprovechando la simpática visita a Buenos Aires de Aracy Amaral, hemos conversado y entendo los problemas que Ud. pueda tener con "determinadas obras de la muestra Perfil Latinoamericano" [...] Nos gostaria mucho conocer su opinión, evitando obras que lo podrían comprometer, de poder hacer una muestra en su Museo. Yo creo, y Aracy me lo ha confirmado, que el único lugar que podríamos exhibir en este momento una muestra importante de argentinos es en su Museo". ${ }^{191}$

191 "Estimado Zanini, aproveitando a simpática visita a Buenos Aires de Aracy Amaral, temos conversado e entendo os problemas que você possa ter com "determinadas obras da mostra Perfil Latino-americano" [...] Gostaria muito de conhecer a sua opinião, evitando obras que poderiam te comprometer, e de poder fazer uma mostra no seu Museu. Eu acho, e Aracy me confirmou, que o único lugar que poderíamos exibir neste momento 
Esse trecho selecionado é relevante para compreender os diversos entraves burocráticos e, principalmente, políticos. Em um momento de repressão e pouca liberdade de expressão, ambas as instituições criaram mecanismos alternativos para evitar problemas com a censura, como respondera Zanini: “as coisas não são nada fáceis aqui, você sabe. Não temos sido museu tumulus, em todo caso...". ${ }^{192}$ Além disso, a correspondência confirma a importância do MAC USP como "único lugar” possível de acolher uma exposição de arte argentina. Quer dizer, como local receptivo de novas linguagens, sobretudo, das práticas conceituais até então pouco compreendidas nos circuitos tradicionais de exibição.

A tentativa de negociar a vinda de uma mostra de arte argentina continuou até 1976, quando o MAC recebeu Década de 70, organizada por Glusberg. Porém, antes de consolidar esse diálogo, alguns artistas ligados ao Grupo de los Trece passaram pelo Museu. E a porta de acesso foi por meio da exposição internacional de arte postal, Prospectiva 74, de 1974, que avaliaremos adiante.

\subsection{1 - Prospectiva 74: ARGENTINOS NO MAC USP}

Prospectiva 74, exposição organizada pelo artista espanhol Julio Plaza e Walter Zanini, fez parte de uma ampla rede internacional de comunicação impulsionada pela arte postal. Essa poética, "surgida na urgência de estruturas de substituição em nível internacional" ${ }^{\prime 193}$, conforme escrevera Zanini, tornou-se uma atividade fundamental que ligou artistas de diversas parte do mundo, a partir da década de 1970. Essa urgência surgiu de novas demandas artísticas que buscavam ir além da unicidade da obra de arte, por meio da conexão de grupos de artistas, cooperativas e outros focos alternativos que operavam distante da lógica do mercado. Inclusive, parte dessas produções não foi idealizada para circular em museus e galerias, ou seja, em espaços institucionalizados. Nesse sentido, ressaltamos o papel do MAC USP como local de resistência e estímulo desse tipo de prática, um receptáculo de propostas

\footnotetext{
uma mostra importante de argentinos é no seu Museu." (tradução nossa). Correspondência de Jorge Glusberg a Walter Zanini. 12 dez. 1973. Arquivo do Museu de Arte Contemporânea da Universidade de São Paulo.

${ }^{192}$ Correspondência de Walter Zanini a Jorge Glusberg. 04 fev. 1974. Arquivo do Museu de Arte Contemporânea da Universidade de São Paulo.

${ }^{193}$ Versão original do artigo A arte postal na busca de uma nova comunicação internacional, publicado no jornal O Estado de S. Paulo, 1977. In: FREIRE, Cristina. (Org.). Walter Zanini: Escrituras Críticas. São Paulo: Annablume: MAC USP, 2013.
} 
pensadas coletivamente com o intuito de descentralizar os canais de distribuição e circulação. O Museu, por meio de seu programa amplo de exposições, conseguia captar e conectar práticas não oficiais em espaços institucionais.

Mais uma vez, o Museu se apoiou na noção de solidariedade e cooperação ao não seguir os métodos tradicionais das convocatórias, marcadas pelo regime de premiações e jurados. $\mathrm{O}$ amplo número de participantes, aproximadamente 150, foi possível pela ideia dos organizadores de que cada artista convidasse uma outra pessoa para ser incluída na exposição. Julio Plaza, que havia organizado uma mostra semelhante em Porto Rico, em 1971, tinha uma lista de nomes e direções que serviram de base para a realização dessa proposição no Museu. No catálogo da mostra, o espanhol procurou explicar as ideias essenciais da convocatória: "Prospectiva 74 tem sido possível graças a uma comunicação em nível internacional entre artistas, que têm demonstrado um espírito de cooperação e de autogestão, só possível quando existe o conceito de INFORMAÇÃO e não de mercadoria”.

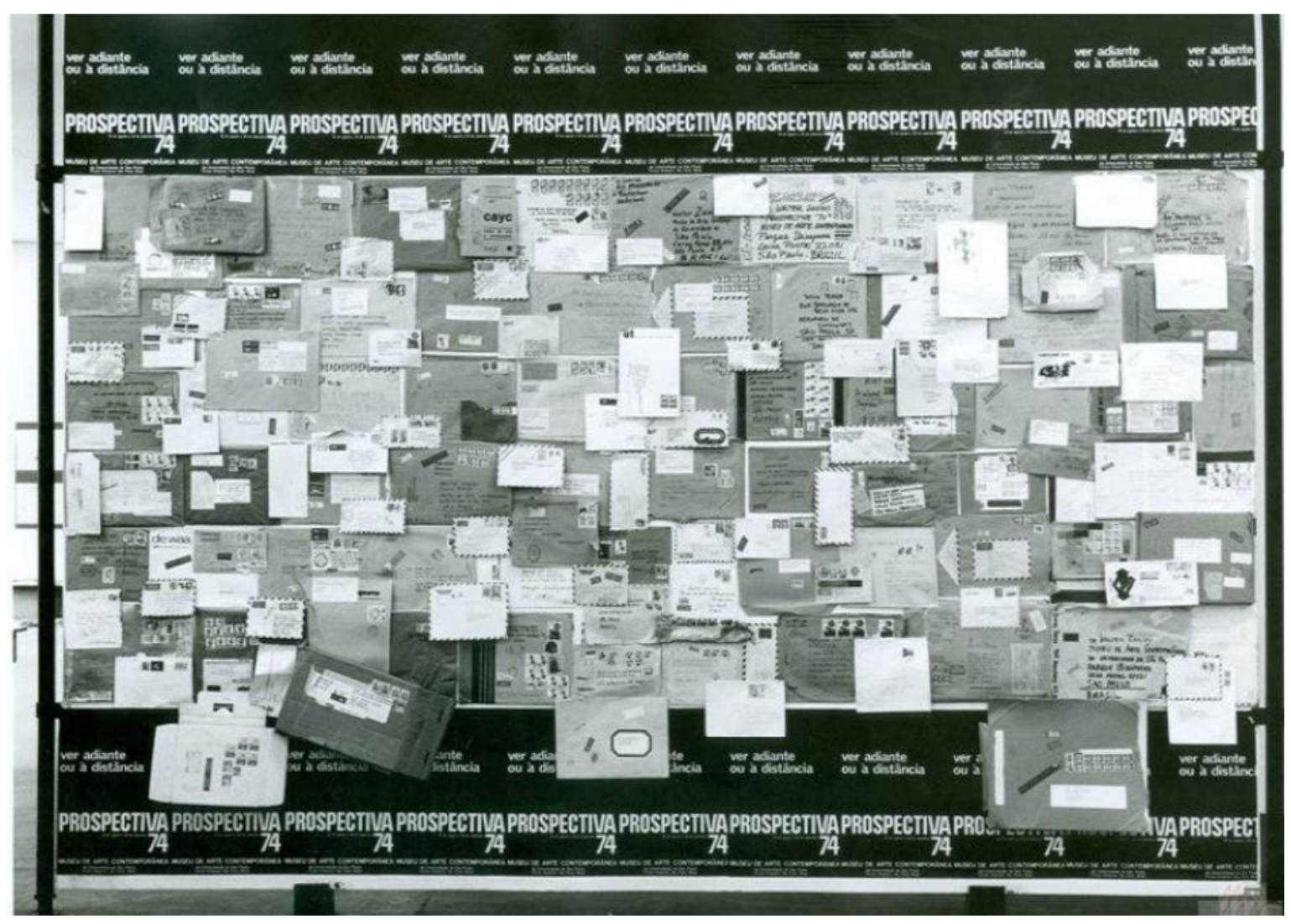

Figura 67 - Painel com as correspondências dos participantes de Prospectiva 74 Fotógrafo: Gerson Zanini, 1974. Arquivo MAC USP 
Centenas de obras resultantes dos novos media e de práticas de base conceitual chegaram ao Museu via correio: postais, publicações alternativas, livros de artistas, mapas, diagramas, poesia visual, fotografia, projeto de instalação, registro de performance, entre outros. O uso privilegiado da palavra e do texto serviu como ampliação e estratégia crítica de comunicação e, sobretudo, como vínculo possível entre distintos territórios (FREIRE,2015, p.47). A arte postal como circuito de comunicação marginal, especialmente, em tempos de ditadura, desencadeou novas estruturas comunicacionais para a linguagem, incluindo "os aspectos mais sugestivos da tendência ao não objeto e ao anonimato que assinalam muitas das realizações artísticas contemporâneas" (ZANINI, 1977) ${ }^{194}$. As obras foram colocadas diretamente nas paredes, sem a necessidade de moldura ou paspatur, em sintonia com parte das propostas que operava na precariedade dos meios e das técnicas utilizadas. A mostra também teve uma programação especial para a projeção de filmes e diapositivos, na qual contou com o envio de um filme produzido por Jorge Glusberg e sua Cooperativa Ediciones del Tercer Mundo. Vale ressaltar a importância do catálogo de Prospectiva 74, idealizado por Julio Plaza, como documento e registro da participação dos artistas envolvidos, além da função de compêndio de todas aquelas novas práticas que vinham sendo realizadas em distintas partes do mundo.

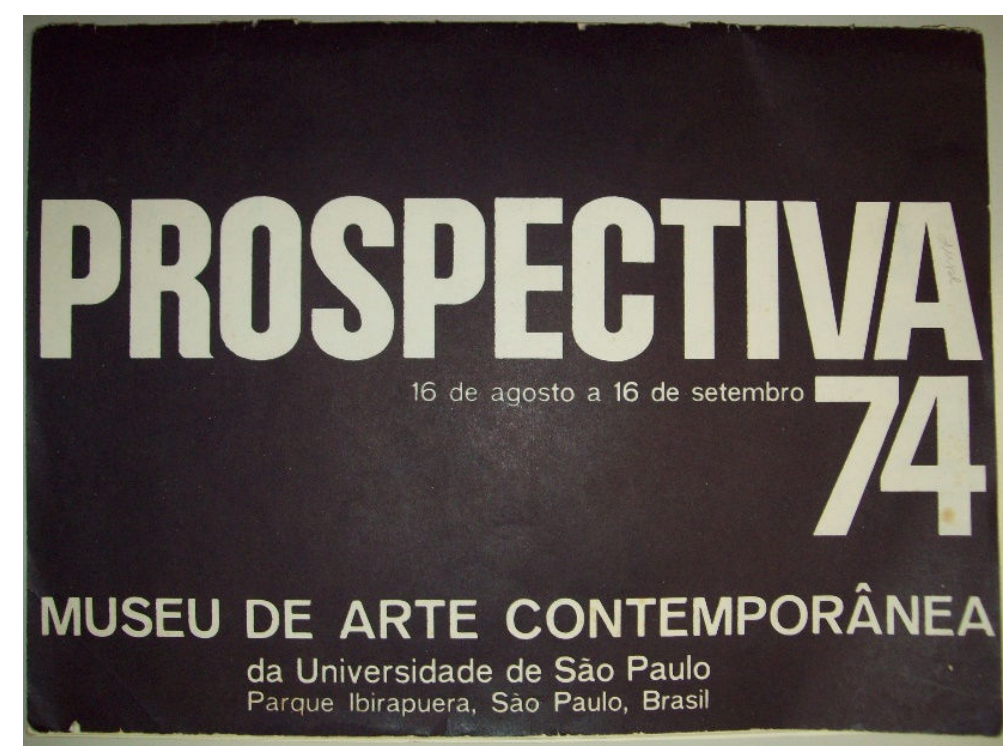

Figura 68 - Catálogo da mostra Prospectiva 74

Concepção: Julio Plaza, 1974. Banco de dados do MAC USP

\footnotetext{
${ }^{194}$ Versão original do artigo $A$ arte postal na busca de uma nova comunicação internacional, publicado no jornal O Estado de São Paulo, 1977. In: FREIRE, Cristina. (Org.). Walter Zanini: Escrituras Críticas. São Paulo: Annablume: MAC USP, 2013.
} 
O perfil de Prospectiva 74 promoveu importantes transformações nos canais de circulação e, sobretudo, na concepção do Museu em sua tarefa de conservar, armazenar e expor obras de arte. O caráter documental das proposições conceituais foi amparado por Zanini, em sua reivindicação por um espaço museológico ao mesmo tempo aberto e resistente, que além de suas funções habituais, impulsionou o colecionismo de obras experimentais e de caráter documental híbrido. ${ }^{195}$ A maior parte das obras enviadas para a exposição entrou para o acervo do MAC USP.

Talvez esse seja um dos pontos que diferencia as gestões de Glusberg e Zanini: o diretor do MAC sempre buscou estimular os novos media simultaneamente à formação de uma coleção multimídia ainda inédita no Brasil. O perfil institucional de Glusberg, por sua vez, baseava-se na divulgação e internacionalização da arte argentina, por meio de mostras itinerantes, sem a preocupação de formar um acervo. A noção de internacionalização e comunicação também foram promovidas por caminhos distintos. Se Glusberg se apropriava de noções estrangeiras para respaldar a linha teórica e artística do CAYC, por meio da arte de sistemas e como mecanismo de internacionalização da produção local, Zanini se apoiava em outras estratégias para ampliar a rede internacional de artistas ligados ao Museu. Inclusive, em uma das correspondências trocadas, Glusberg demonstra interesse por Prospectiva 74, contudo Zanini diz não ser possível o envio da exposição para Buenos Aires, pois o Museu tinha a intenção de organizar a sua itinerância pelo Brasil. ${ }^{196}$

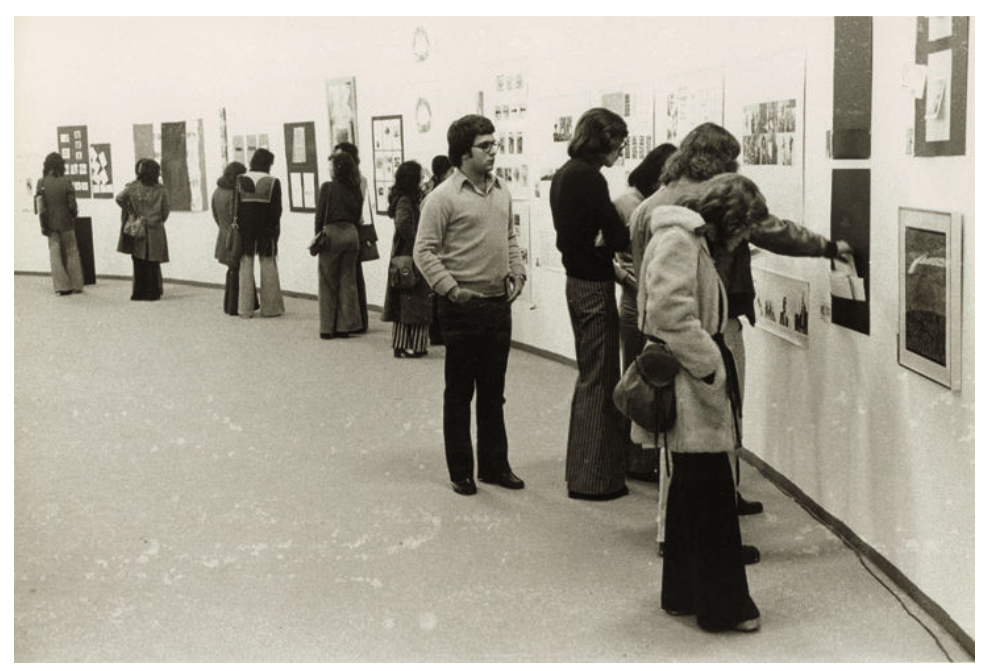

Figura 69 - Vista parcial da mostra Prospectiva 74 Fotógrafo: Gerson Zanini, 1974. Arquivo MAC USP

\footnotetext{
${ }^{195}$ FREIRE, Cristina. La red en exposición: Prospectiva 74. Revista Índex, v.1, p. 8-11, 2011. In: http://www.macba.cat/uploads/20111122/02_cas.pdf - acesso em 20 jul. 2015.

196 Correspondência de Walter Zanini a Jorge Glusberg. 13 nov. 1974. Arquivo do Museu de Arte Contemporânea da Universidade de São Paulo
} 
Como a convocatória de Prospectiva 74 baseava-se no sistema de convite e indicação, Glusberg indicou Luis Pazos, conforme uma correspondência enviada pelo artista argentino a Walter Zanini. Nessa carta, Pazos se apresenta e comenta sobre o trabalho enviado para participar da exposição:

Mi especialidade es el "arte en acción", es decir, obras en las que yo mismo soy la materia del arte y su representación. En este caso en especial se trata de un ritual medieval realizado por mi mismo (figura central) y muñecos con la escenografía correspondiente. [...] Desde ya le deseo el mayor de los éxitos en el evento y lo saludo con mi mayor consideración. ${ }^{197}$

Pazos, artista e poeta, foi integrante do Grupo de los Trece e colaborou, durante os anos de 1970, para a revista Diagonal Cero ${ }^{198}$, coordenada por Edgardo Antonio Vigo. A arte de acción ou arte-actitud, denominada pelo artista, fundava-se nas práticas artísticas em busca da participação mais ativa do espectador e na aproximação entre arte e vida, por meio de trabalhos coletivos em detrimento da obra única. Uma de suas obras mais emblemáticas da "arte de ação" foi uma série de registros de performance intitulada Transformaciones de masa en vivo, de 1973, que realizou com a colaboração de diversos estudantes, a maioria alunos de Vigo, na cidade de La Plata. A ideia principal do artista era trabalhar com o corpo como matéria artística, por meio da configuração de várias formas em distintos ambientes. Em uma das fotografias, os jovens formavam as letras $\mathrm{P}$ e $\mathrm{V}$, que na época eram popularmente conhecidas entre os grupos militantes como Perón Vence. Em entrevista, Pazos comentou sobre o final trágico desses estudantes que participaram da performance. Muitos deles, por praticarem a militância ligada à Juventude Peronista durante a ditadura militar, desapareceram ou foram mortos. "Encontro-me com uma obra que é testemunha de algo aterrorizante, que não era essa a sua intenção [...] Eu tinha pensado em fazer um body-work coletivo [...] uma arte experimental e acabou sendo uma tragédia" ${ }^{199}$. Vale mencionar que os estudantes não foram mortos por terem participado da performance, mas evidencia-se nessa relação o lado

\footnotetext{
197 "Minha especialidade é a "arte de ação", quer dizer, obras nas quais eu mesmo sou a matéria da arte e sua representação. Neste caso especial se trata de um ritual medieval realizado por mim mesmo (figura central) e bonecos com a cenografia correspondente. [...] Desde já lhe desejo o maior êxito no evento e o saúdo com a minha maior consideração." (tradução nossa). Correspondência de Luis Pazos a Walter Zanini. 30 abr. 1974. Arquivo do Museu de Arte Contemporânea da Universidade de São Paulo

${ }^{198}$ A revista Diagonal Cero (1962-1968) se dedicou à divulgação de poesia experimental, reunindo textos críticos das vanguardas concretas, xilogravuras, textos literários de artistas argentinos, sobretudo, os da região de La Plata.

199 Entrevista concedida à Cristina Freire, em 2008, na Argentina. In: FREIRE, Cristina. (Org.). Terra incógnita. Conceitualismos da América Latina no acervo do MAC USP. São Paulo: Museu de Arte Contemporânea da Universidade de São Paulo, 2015, p. 103.
} 
perverso da violência exercida pela ditadura, cuja obra torna-se depositária irreversível dessa memória trágica.

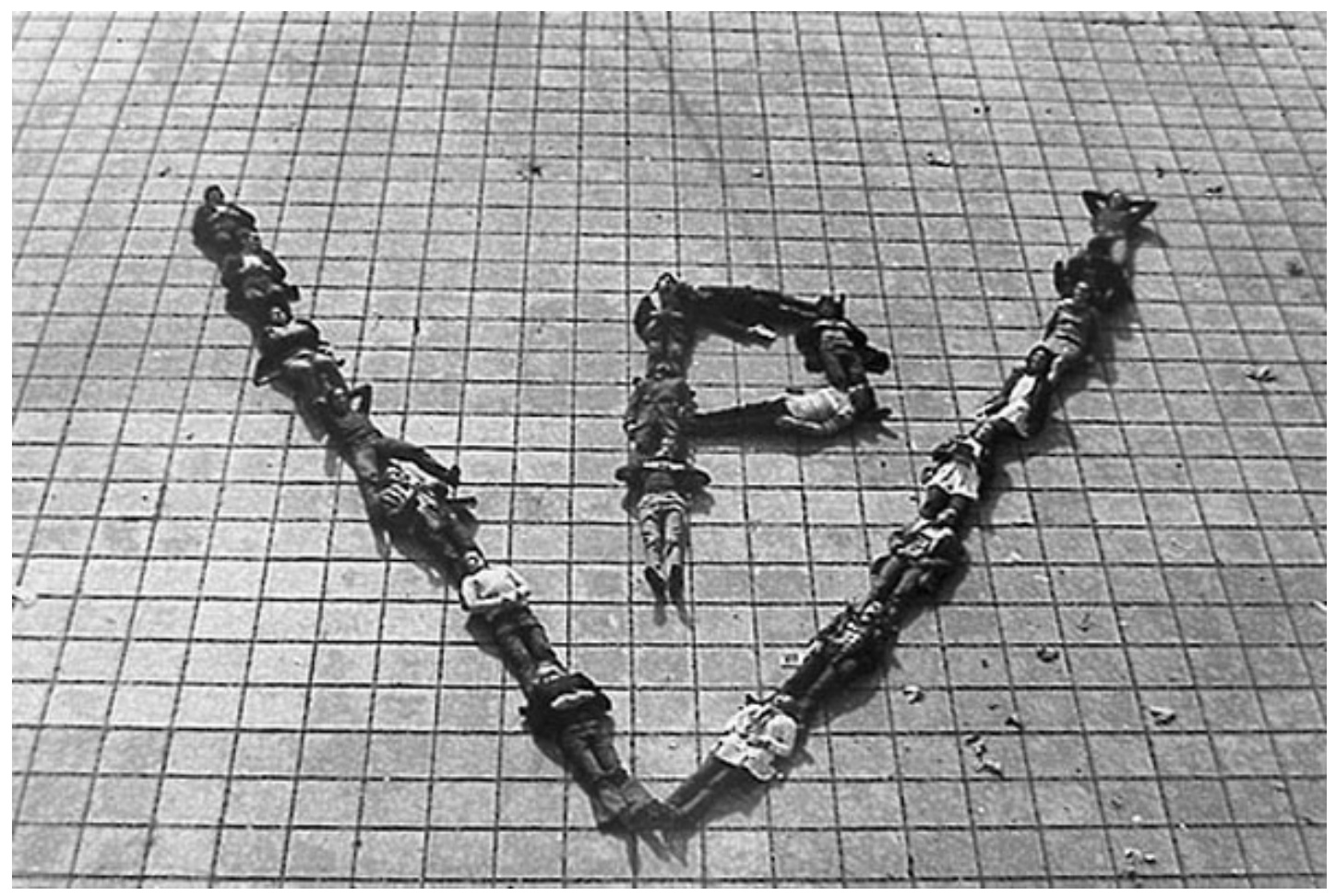

Figura 70 - Luis Pazos, Transformaciones de masa en vivo Registro de performance, 1973

Para a mostra Prospectiva 74, Luis Pazos enviou seis registros fotográficos de uma performance realizada no CAYC, naquele mesmo ano, chamada La Ciudad poseída por los Demonios. A performance baseou-se em um ritual medieval ocorrido em uma aldeia francesa, onde um sacerdote e uma freira se apaixonaram e, por terem desobedecido as regras, foram queimados em uma fogueira. A história foi recontada por Pazos, que representou a figura do inquisidor. Coberto por um capuz, vestimentas negras e um crucifixo, o artista recriou o ritual medieval, deslocando o relato da aldeia para o contexto argentino dos anos de 1970. Como marca de sua arte de acción, Pazos utilizava o corpo como território poético e político, trazendo à tona a realidade brutal do regime militar. 

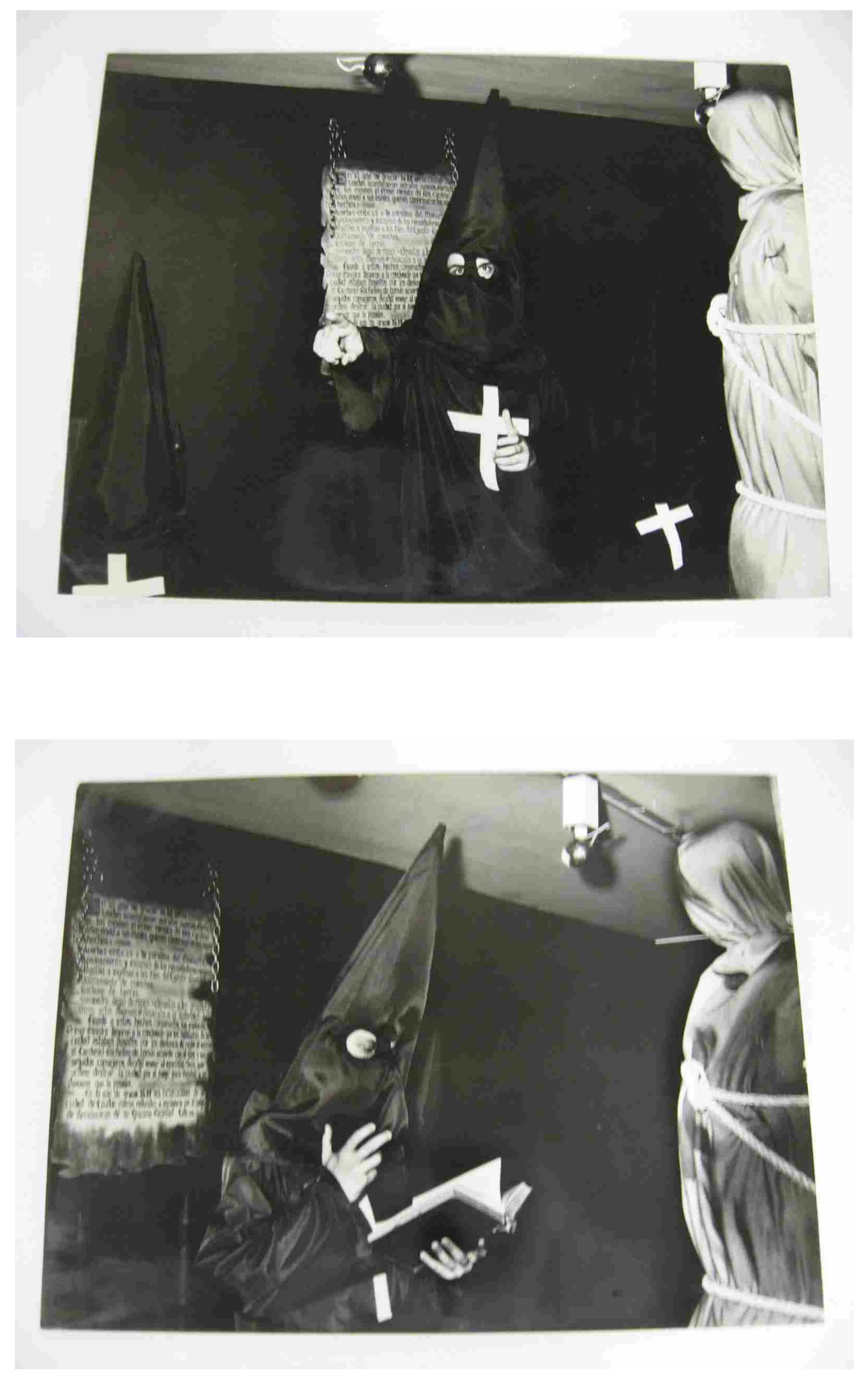

Figura 71 - La ciudad poseída por los demonios, Luis Pazos, Registro de performance, 86,1 x $58 \mathrm{~cm}$ (detalhe), 1974 Banco de Dados do MAC USP

Juan Carlos Romero, artista ligado ao Grupo de los Trece, também participou da mostra. Da região de La Plata, o argentino foi professor de gravura, além de estar próximo de grupos sindicais e da organização guerrilheira Montoneros. Identificado pela crítica da época como a "fracción política" do Grupo de los Trece, buscava definir a arte como "la 
concientización del presente" de "fuerte contenido ético y aun politico" momento, era vista como uma ferramenta para a conscientização da realidade, um meio para refletir sobre a dependência, o subdesenvolvimento e a violência. Para participar da mostra Prospectiva 74, o artista enviou a série Violencia ${ }^{201}$, que vinha desenvolvendo há alguns anos em Buenos Aires. Tratava-se de uma pesquisa em diferentes meios de comunicação sobre os múltiplos significados do termo violência. Um ano antes, Romero exibira no CAYC uma instalação homônima, deixando expostos os conflitos entre o espaço da arte e as urgências políticas, por meio da reiteração da violência em suas diversas facetas. Ocupando os três andares do Centro, a instalação consistia em uma montagem complexa de textos de diferentes fontes, imagens e capas de jornal sobre a temática.

A violência era analisada a partir dos campos da psicanálise, da literatura do jornalismo e da filosofia; e seu significado definido ora pela Bíblia, ora por Che Guevara ou Mao Tsé-Tung, era estampado em cartazes. Romero também se apropriou de jornais conhecidos como prensa amarilla, um tipo de imprensa sensacionalista que divulgava escândalos e notícias violentas. Com o recurso da gráfica popular utilizada nos circuitos informacionais e políticos das ruas, o artista reproduziu dezenas de cartazes com a palavra Violencia, cobrindo o chão e as paredes do CAYC. O deslocamento e repetição do termo ampliavam a sua reverberação, por meio da acumulação gráfica e semântica (FREIRE, 2015, p. 50). A violência era definida por Romero como "omnipresente y multiforme, brutal, abierta, sutil, insidiosa, dissimulada, racionalizada, científica, condensada, solidificada, consolidada, anónima, abstracta, irresponsable”, de acordo com o catálogo da exposição. A obra enviada para o MAC USP era composta por nove impressões off-set e uma xilogravura e, como vimos, fazia parte da investigação desenvolvida por Romero sobre o tema da violência.

\footnotetext{
200 “A conscientização do presente de forte conteúdo ético e ainda político.” (tradução nossa). El Arte como conciencia en Argentina. In: DAVIS, Fernando; ROMERO, Juan Carlos; LONGONI, Ana. Romero. Buenos Aires: Fundación Espigas, 2010.

${ }^{201}$ A instalação Violencia foi reapresentada na $31^{\text {a }}$ Bienal de São Paulo, em 2014.
} 

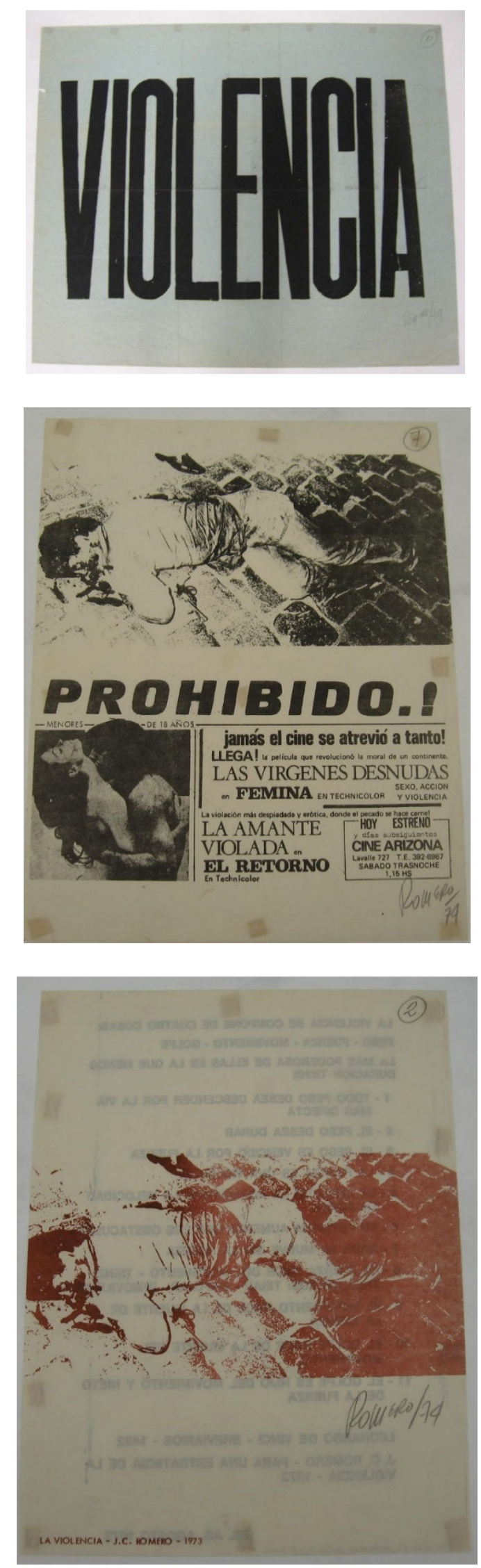

Figura 72 - Violencia, Juan Carlos Romero Detalhe das obras enviadas para Prospectiva 74, 1974 Banco de Dados do MAC USP 
Outro argentino que esteve presente na mostra Prospectiva 74 foi Edgardo Antonio Vigo. Embora não fizesse parte do Grupo de los Trece, participou de diversas exposições no CAYC. Artista, poeta e editor, Vigo foi um dos precursores das tendências conceitualistas e da poesia experimental na Argentina, tornando-se referência para vários artistas como Luis Pazos e Horacio Zabala. Foi editor de publicações dedicadas à poesia visual e à arte experimental, como Diagonal Cero e Hexágono 71. O artista propôs várias modificações no formato de suas revistas com o intuito de alterar a sua unidade estrutural, transformando aquele formato único em uma espécie de revista-objeto, na qual o leitor poderia escolher a melhor forma de manuseio e interação. Participou ativamente da rede internacional de arte postal, mantendo estreita relação com Walter Zanini, como demonstram algumas cartas trocadas entre o artista e o diretor do MAC. Em uma delas, Vigo escreve:

Estimado amigo, muchas gracias por su carta de 1.'75. Además me tranquiliza Ud. por la recepción de mi trabajo y estoy muy contente que haya sido de su gusto. [...] en consecuencia insisto que mi vía comunicativa es la correspondencia, a la cual me he habituado y además la he elegido como vía de realización de mis últimos intentos, pues mi apasiona el ARTE POR CORRESPONDENCIA. ${ }^{202}$

Vigo, como artista-editor, organizava as publicações e as devolvia à circulação na forma de revistas, livros de artistas, distante da lógica mercadológica. A arte postal ou arte por correspondência, como definiu o artista, representava um processo de descentralização artística, na qual mensagens podiam ser enviadas para qualquer canto do mundo. Geralmente a organização de uma rede de artistas consistia na escolha da tiragem determinada pelo número de participantes que, após receberem uma carta-convite, enviavam seus trabalhos em formato e quantidade previamente estabelecidos (FREIRE, 2015, p. 27). Desse modo, o MAC USP ingressou nessa rede internacional, constituindo-se como local possível de abrigo e estímulo dessa produção contra oficial. Prospectiva 74 representou a consolidação desse diálogo amplo entre artistas de diversos pontos do mundo. Ou como escrevera Zanini, no texto de apresentação do catálogo da mostra:

A repercussão internacional de PROSPECTIVA 74, comprovada pela densa presença individual de artistas de numerosos países, abre a meu ver um

\footnotetext{
202 "Estimado amigo, muito obrigado por sua carta de 1-75. Aliás, você me tranquiliza pela recepção do meu trabalho e estou muito contente que tenha gostado. [...] Em consequência insisto que minha via comunicativa é a correspondência, da qual tenho me habituado, e escolhido como via de realização das minhas últimas proposições, pois me apaixona a arte por correspondência.” (tradução nossa). In: FREIRE, Cristina. (Org.). Terra incógnita. Conceitualismos da América Latina no acervo do MAC USP. São Paulo: Museu de Arte Contemporânea da Universidade de São Paulo, 2015.
} 
caminho que sob aspectos importantes parecia fechado nestes últimos anos ao nosso país. Um diálogo profundo poderá estabelecer-se com os artistas brasileiros. O MAC tem procurado incessantemente facilitar este contato com a área mundial, como atestam suas exposições e sua atuação no estrangeiro (ZANINI, 1974).

Veremos a seguir os fluxos dessas redes internacionais, com foco na mostra heliográfica Década de 70, organizada por Jorge Glusberg, que entrou no programa de exposições do MAC USP, em 1976. A realização dessa mostra no Brasil foi fruto de alguns anos de diálogo e afinidades mútuas em projetos de arte experimental e pela produção ligada às vanguardas internacionais. Embora não tenha tido muita repercussão no meio cultural e na imprensa, Década de 70 pode ser considerada um degrau para a grande consolidação dos artistas ligados ao CAYC e, sobretudo, de Jorge Glusberg, quando ganharam o Prêmio Itamaraty na XIV Bienal de São Paulo, um ano depois.

\subsection{2 - DÉCADA DE 70: CONSOLIDAÇÃO DAS TROCAS ARTÍSTICAS}

Década de $70^{203}$ foi inaugurada nos primeiros meses de 1976 no edifício do MAC USP. A mostra de heliografias concebida por Jorge Glusberg contava com o trabalho de mais de cem artistas, entre latino-americanos, europeus e norte-americanos. A exposição era uma extensão do programa conceitual desenvolvido pelo diretor do CAYC, cuja orientação teórica se ajustava a montagens anteriores, como Arte de Sistemas e Hacia un perfil del arte latinoamericano. O modelo curatorial também era similar: o desenho espacial, o uso de heliografias, dimensões padronizadas com as legendas ao lado direito e abaixo do papel heliográfico, o texto didático etc. Ou seja, a ordem discursiva da mostra era praticamente a mesma, tendo como eixo de articulação as produções ligadas à arte de sistemas. Os artistas enviavam pelo correio as obras em um papel de 60 por $90 \mathrm{~cm}$ e em Buenos Aires elas eram reproduzidas por meio da técnica heliográfica (HERRERA, 2013, p. 23). Esse ponto de partida metodológico facilitava a circulação das mostras, que podiam ser montadas facilmente em qualquer espaço.

O discurso da exposição procurava se distanciar da noção de autonomia das artes visuais e do fenômeno da criação individual, pautando-se na dependência das condições

\footnotetext{
${ }^{203}$ Decada del 70 foi exibida pela primeira vez em 1974, no Museo de Ciencias y Artes, no México. Em 1976,
} foi enviada ao MAC USP e, no ano seguinte, ao Museo Universitario de Ciencias y Artes, também no México. 
subjetivas de produção do artista. Ao acionar a ideologia como fator constituinte de quaisquer manifestações artísticas e culturais, o artista poderia se identificar com alguma tendência, elegendo sua produção a partir de seu repertório social. E essa era a base do Grupo de los Trece dentro das exposições, além de servir de exemplo para ilustrar as práticas artísticas contemporâneas. Embora seus integrantes trabalhassem por meio de uma multiplicidade de propostas, era possível detectar uma coincidência ou um eixo de afinidade em suas realizações estéticas. Essa confluência estrutural, como vimos, era articulada pela categoria arte de sistemas.

He aqui el punto de confluencia de los integrantes del Grupo y de muchos creadores actuales: la permanente revelación del proceso estético y de sus causas sociales. Estos artistas se interesan por lo que sucede en la sociedad donde viven, no por las representaciones académicas [...] Desean comunicarse con la audiencia, y están seguros de lograrlo sin la participación de los tradicionales "intermediarios", esto es, directamente, en aquellos lugares donde todos pueden intervenir y colaborar con ellos (GLUSBERG, $1977)^{204}$.

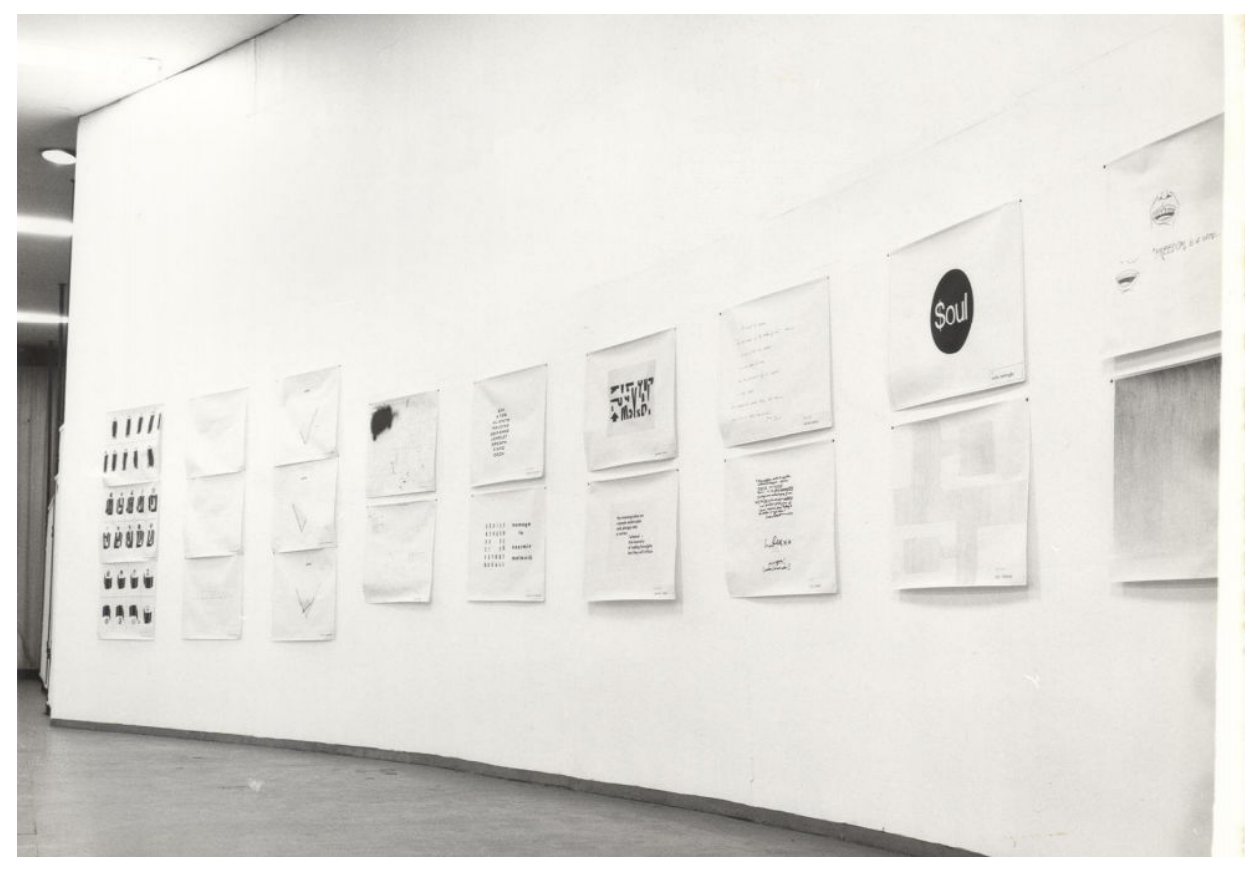

Figura 73 - Vista parcial da mostra Década de 70

Fotógrafo: Gerson Zanini, 1976. Arquivo do MAC USP

\footnotetext{
204 "Há aqui o ponto de confluência dos integrantes do Grupo e de muitos criadores atuais: a permanente revelação do processo estético e de suas causas sociais. Esses artistas se interessam pelo que sucede na sociedade na qual vivem, não pelas representações acadêmicas [...] Desejam comunicar-se com a audiência, e estão seguros de consegui-lo sem a participação dos tradicionais 'intermediários', isto é, diretamente naqueles lugares onde todos possam intervir e colaborar.” (tradução nossa).
} 
Glusberg afirmava que ao explicitar as condições de produção, o artista afetava os mercados econômicos e os circuitos de difusão de arte tradicional. O discurso artístico experimental, segundo o diretor do CAYC, não pactuava com as redes de interesse da arte oficial e, sobretudo, não pretendia agradar ou satisfazer as demandas do "terreno mercantilista", mas sim propor novas experiências estéticas. E um dos modos de se apartar dos setores privilegiados era democratizando o acesso à cultura, por meio dos novos canais de circulação e distribuição das obras. E por uma "razão de economia", diante da impossibilidade de competir com os circuitos comerciais,

ha presidido el empleo del papel heliográfico para la realización de las obras que componen Década del 70. [...] Este sistema económico y facilmente reproducible, que nos es produto del azar, se convierte así en outro rasgo distintivo de un arte que promueve la eliminación de la clausura esteticista [...] (GLUSBERG, 1977) ${ }^{205}$.

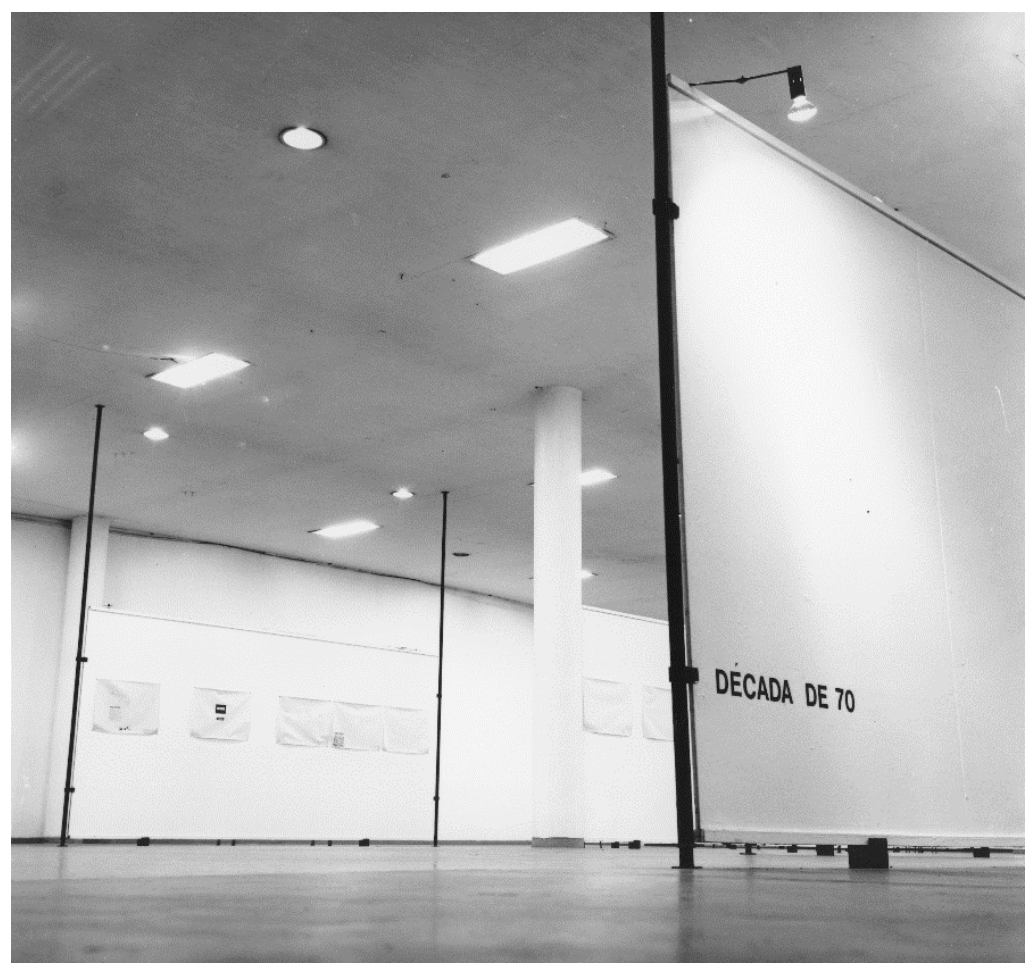

Figura 74 - Vista parcial da mostra Década de 70

Fotógrafo: Gerson Zanini, 1976. Arquivo do MAC USP

205 “tem presidido o emprego do papel heliográfico para a realização das obras que compõem Década de 70. [...] Este sistema econômico e facilmente reproduzível, que não é produto do azar, se converte assim em outro ponto distinto de uma arte que promove a eliminação da prisão estética [...]." (tradução nossa). 
Vimos anteriormente que Zanini e Glusberg estabeleceram um fértil diálogo desde 1972, buscando compartilhar exposições, negociar a vinda de artistas e intelectuais internacionais, intermediar propostas e convites para a participação de seminários e congressos. Ao longo desses anos, Glusberg tentou enviar ao MAC USP diversas mostras ligadas ao CAYC, como Hacia un perfil del arte latinoamericano e Arte de sistemas en la Argentina, mas por adversidades burocráticas e políticas, não puderam ser exibidas. Nesse sentido, evidenciamos a importância de Década de 70 por consolidar o intercâmbio iniciado anos antes e, principalmente, por preencher uma lacuna na agenda latino-americana do CAYC. O Centro havia organizado a itinerância de suas exposições por outros países vizinhos, como Chile, Colômbia e México. Embora alguns artistas ligados ao CAYC haviam passado pelo MAC, faltava completar essa rede de trocas com a inauguração de uma exibição promovida por Glusberg no Brasil. Outro ponto que deve ser ressaltado é que a passagem de Década de 70, além de divulgar a vanguarda experimental argentina, serviu para sedimentar o trânsito do CAYC pelo país até o seu retorno no ano seguinte, quando levou o grande prêmio da XIV Bienal de São Paulo.

$\mathrm{Na}$ ocasião da abertura, Zanini registrou: "Glusberg, tudo bem conforme o meu telegrama. Década de 70 será inaugurada dia 18 de agosto, num espaço de $1.000 \mathrm{~m}^{2}$. Providenciamos um pequeno catálogo que logo lhe enviarei". 206

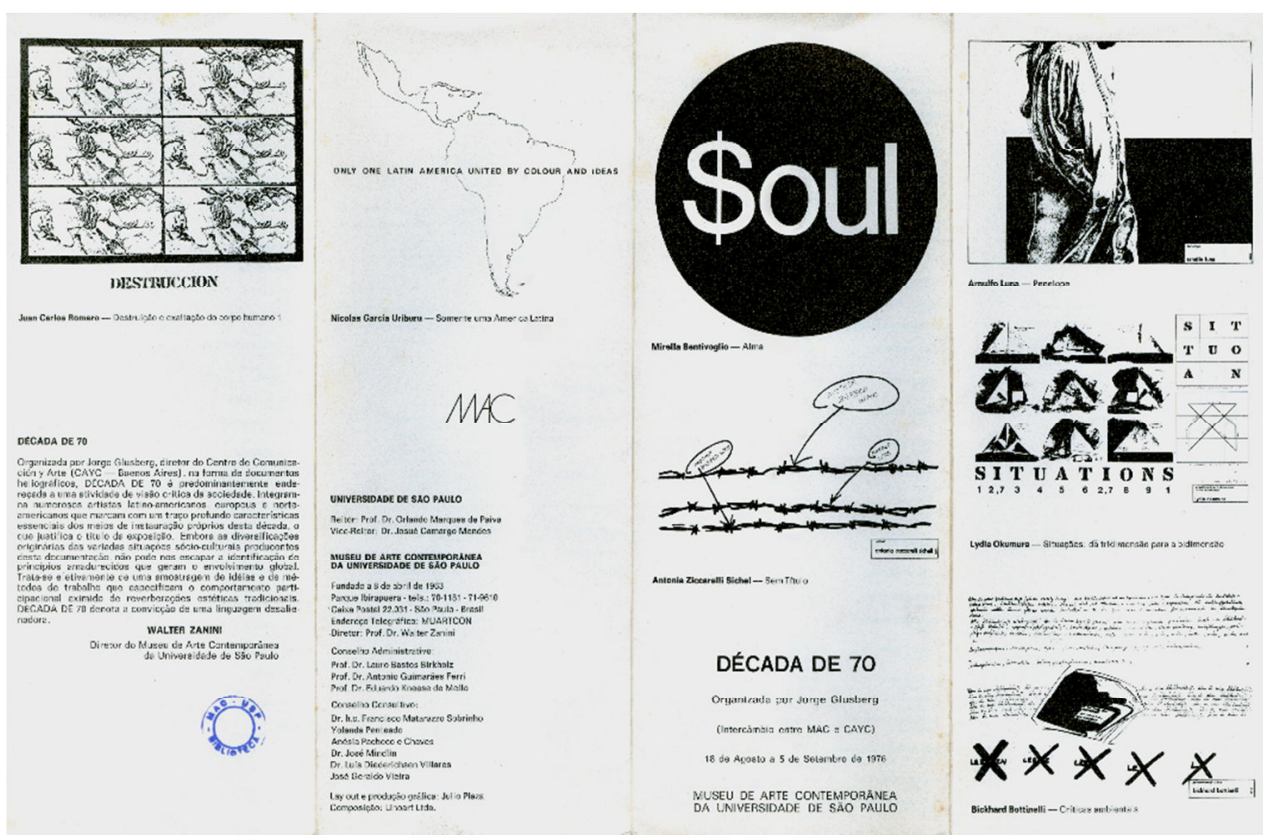

\footnotetext{
${ }^{206}$ Correspondência de Walter Zanini a Jorge Glusberg. 17 ago. 1976. Arquivo do Museu de Arte Contemporânea da Universidade de São Paulo
} 
Figura 75 - Detalhe do catálogo da mostra Década de 70, 1976

Biblioteca Lourival Gomes Machado

No catálogo da versão brasileira, Zanini escreveu:

Organizada por Jorge Glusberg, diretor do Centro de Comunicación y Arte (CAYC - Buenos Aires), na forma de documentos heliográficos, DÉCADA DE 70 é predominantemente endereçada a uma atividade de visão crítica da sociedade. Integram-na numerosos artistas latino-americanos, europeus e norte-americanos que marcam com um traço profundo características essenciais dos meios de instauração próprios desta década, o que justifica o título da exposição. Embora as diversificações originárias das variadas situações sócio-culturais producentes desta documentação, não pode nos escapar a identificação de princípios amadurecidos que geram o envolvimento global. Trata-se efetivamente de uma amostragem de ideias e de métodos de trabalho que especificam o comportamento participacional eximido de reverberações estéticas tradicionais. DÉCADA DE 70 denota a convicção de uma linguagem desalienadora.

Todos os integrantes do Grupo de los Trece participaram da exposição, sendo possível ter uma visão geral de suas produções amparadas pelo discurso de Glusberg sobre arte de sistemas e conceitualismo ideológico. Embora cada artista tivesse a sua particularidade, era possível detectar certas preocupações ou procedimentos afins. Por exemplo, o resgate de materiais, culturas, ofícios, ritos e comportamentos que compunham um passado, próximo ou distante, e, por meio desse retorno, encontrar uma identidade latino-americana comum. $\mathrm{Ou}$ ainda, a investigação crítica da realidade e seus aspectos sociopolíticos. Essas eram algumas das questões que podiam ser consideradas nos labirintos artificiais de Benedit, nos rituais mítico-religiosos de Portillos, nos resíduos arqueológicos de Bedel, na energia das batatas de Grippo, na pesquisa sobre violência de Romero, nas metáforas biológicas de González Mir, nas obras de ação de Pazos, na destruição ecológica de Testa, nas cartografias de Zabala, nas tipologias urbanas de Glusberg etc. "Sendo um grupo formado na ambiência cosmopolita da arte conceitual, o que lhe dá unidade é algo que extrapola o campo visual ou formalista" (MORAIS, 1979, p. 57).

Vimos que o modus operandi do Grupo de los Trece foi marcado por uma lógica geopolítica, ao utilizar uma linguagem internacional, a arte conceitual, para propor uma inversão por meio de um modelo regional. Se a mostra Década de 70 representou a consolidação do diálogo entre Glusberg e Zanini e uma oportunidade para reunir todos os integrantes do Grupo de los Trece no Brasil, examinaremos adiante o êxito dessa proposta com a polêmica premiação do CAYC na XIV Bienal de São Paulo, em 1977. 


\subsection{3 - SignOS EM ECOSSISTEMAS ARTIFICIAIS - UMA PREMIAÇÃO POLÊMICA}

A XIV Bienal Internacional de São Paulo, de 1977, antes mesmo de ser inaugurada, já estava envolvida em uma série de polêmicas. A começar pela mudança no regulamento que visava alterar a representação de países para divisões temáticas. $\mathrm{O}$ novo regulamento elaborado pelo Conselho de Arte e Cultura da Fundação Bienal apresentava os seguintes temas: Arqueologia do Urbano, Recuperação da Paisagem, Arte Catastrófica, Vídeo Tape e Poesia Espacial. A imprensa divulgou diversas matérias sobre a mudança do regulamento, a maior parte demonstrando desconfiança nas modificações. Os controvertidos itens do novo regulamento permitiam apontar inúmeras falhas e contradições, "além de caracterizar um sentido antidemocrático no que diz respeito ao caráter pouco abrangente e restritivo de suas imposições cronológicas e temáticas". ${ }^{207} \mathrm{O}$ receio em relação à organização dos temas se dava pelo risco de cair no terreno da catalogação das vanguardas, impondo sugestões e assuntos a serem explorados. Vimos que a Bienal de São Paulo passava por longo período de crise, alavancada pelos boicotes locais e internacionais, desde 1969. Vale lembrar que em 1977, Ciccillo havia falecido, deixando uma enorme lacuna institucional. Sem o comando do fundador da Bienal, as edições passaram a ser organizadas pelo CAC - Conselho de Arte e Cultura.

Nesse ano, além da apresentação do novo regulamento, a instituição lançou a pedra fundamental da Bienal Latino-americana, que seria realizada nos anos pares. Buscava-se com essas propostas renovar todas as diretrizes práticas e teóricas da Fundação Bienal, propondo um novo espaço para experimentação ao invés da consagração. Contudo, os mecanismos de premiação tiveram continuidade, gerando uma série de polêmicas, como analisaremos adiante.

O Conselho constituiu a mostra em três eixos: Exposição Antológica, Grandes Confrontos e Proposições Contemporâneas. Esta última ambicionava abarcar as preocupações artísticas mais frequentes da atualidade. Arqueologia do Urbano, por exemplo, visava “documentar o homem em conflito com a cidade". Recuperação da Paisagem pretendia instigar a reflexão sobre "as manifestações visuais do meio natural". Arte Catastrófica propunha a ideia de ruptura e perturbação na "rotina de um sistema qualquer". Vídeo Arte, por sua vez, buscava ressaltar o caráter documental da produção em vídeo, "não como técnica,

207 O contraditório Regulamento da XIV Bienal. LEIRNER, Sheila. O Estado de São Paulo. 13-03-1977. Arquivo Multimeios do Centro Cultural São Paulo. 
mas sim como forma de conhecimento". Poesia Espacial recorria ao poema literário, que se tornou visual, por meio da discussão sobre o "espaço por autores plástico-visuais". Já O Muro como Suporte de Obras, procurava ampliar o conceito de muro, "onde uma sociedade se comunica", podendo "dividir, unificar ou revelar nosso destino". E por último, Arte NãoCatalogada, buscava inserir "pesquisadores de projetos ainda não classificados pelo consumo, nem codificados pela crítica"208. Além dos núcleos temáticos, o Conselho de Arte e Cultura apresentava a reformulação das salas especiais por meio de exposições antológicas, cujo homenageado seria o pintor mexicano Rufino Tamayo. A programação geral incluía, também, a realização de um simpósio internacional denominado $O$ Contemporâneo na Arte, com a participação de vários críticos e intelectuais, como Gregory Battcock, Vilém Flusser, Jorge Glusberg, entre outros.

Apesar disso, todas essas inovações propostas pela XIV Bienal foram vistas com receio por parte da crítica de arte. A opinião contrária era justificada por diversos motivos: desde o gasto excessivo à desorganização e mau funcionamento da exposição. A seção de videoarte, por exemplo, não funcionou por dias consecutivos, porque a Bienal não havia providenciado o equipamento necessário. Por sua vez, o critério temático era criticado por sua "caducidade" pela crítica mais comprometida com a vanguarda, ou por seu "excesso vanguardista”, pela ótica mais conservadora. Frederico Morais escrevera na ocasião:

Todos concordam que a criação de novas categorias e ou seções temáticas substituindo a anterior divisão por países é, em si mesmo, um dado positivo, mas também, unanimemente, estão de acordo que, na prática, esta primeira tentativa frustrou-se. Por incompreensão dos artistas ou comissários estrangeiros, devido à montagem (que não conseguiu explicitar, didaticamente os temas propostos) e, o que parece lógico concluir, por incapacidade da própria comissão cultural da Bienal em explicar os critérios que formulou. ${ }^{209}$

Entretanto, o que gerou mais mal-estar foi a premiação ${ }^{210}$. Antes mesmo de ser divulgada, deflagrou uma série de especulações e polêmicas. A imprensa publicou algumas matérias sobre os possíveis premiados, sugerindo o grande prêmio Itamaraty ao artista Frans

\footnotetext{
${ }^{208}$ Catálogo da XIV Bienal Internacional de São Paulo. São Paulo: Fundação Bienal, 1977, p. 3.

${ }^{209}$ As inovações frustradas. MORAIS, Frederico. O Globo. 07-10-1977. Arquivo Multimeios do Centro Cultural São Paulo.

${ }^{210}$ O júri de premiação era composto por Clarival do Prado Valladares (Brasil); Marcia Tucker (EUA); Silvia de Ambrosini (Argentina); Tommaso Trini (Itália); Toshiaki Minemura (Japão).
} 
Krajcberg, veterano em participações na Bienal (o polonês, naturalizado brasileiro, havia exposto na $1^{\mathrm{a}}$ Bienal, de 1951). Porém, ao circular a notícia que Krajcberg ganharia um prêmio menor, o artista ameaçou retirar a obra da exposição. As controvérsias foram acirradas quando o presidente da Bienal fez o pronunciamento oficial: o grande premiado foi o Grupo de los Trece. Após 26 anos, era a primeira vez que a Bienal laureava um representante latinoamericano. Inconformado com o prêmio de 50 mil cruzeiros, Krajcberg declarou que não aceitava o "prêmio consolação" que deveria ser destinado a um jovem e não a um artista com a trajetória de mais de 25 anos de produção. Durante o anúncio, o polonês foi à frente dizer que recusava o prêmio, sugerindo que fosse dado ao Grupo Etsedron ${ }^{211}$, que por sua vez, não aceitou a recompensa.

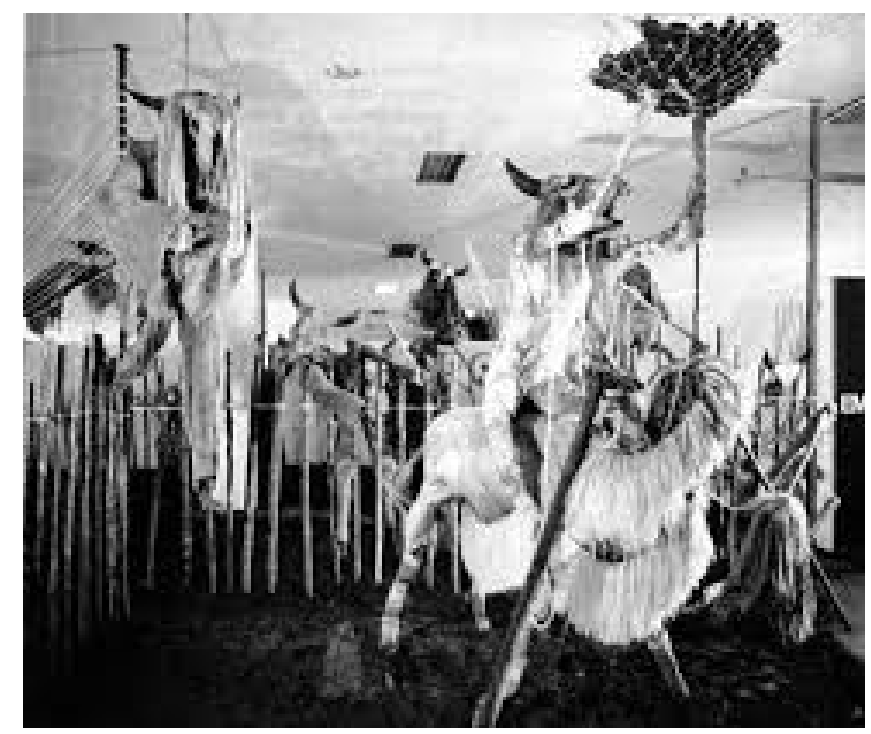

Figura 76 - Instalação do Grupo Etsedron XIII Bienal Internacional de São Paulo, 1975

A premiação ao grupo argentino era uma forma dos jurados não se comprometerem, pois, segundo Krajcberg, "o que aconteceria se eles premiassem o Grupo Etsedron, por exemplo, e mostrassem ao mundo toda uma visão da miséria brasileira? ". De acordo com o artista, o Grupo de los Trece era financiado por um magnata que teria apostado "muito

\footnotetext{
${ }^{211}$ O Grupo Etsedron participara das duas edições anteriores da Bienal, em 1973 e 1975. De acordo com Aracy Amaral, Etsedron revelava a emergência da expressão plástica mestiça brasileira, na presença de uma expressão da realidade cultural sertaneja. E representava "a "matéria" da terra, manipulada artesanalmente. Em equipe, de forma comunal. Social". In: AMARAL, ARACY. Textos do Trópico de Capricórnio. Artigos e ensaios (19802005). Vol. 2: Circuitos de Arte na América Latina. São Paulo: Editora 34, 2006, p. 268-270.
} 
dinheiro" na exposição. E completava: "como podem deixar que vença um grupo de ricos, enquanto o artista nacional luta contra a sua condição de pobreza e falta de estímulo? ". ${ }^{212}$

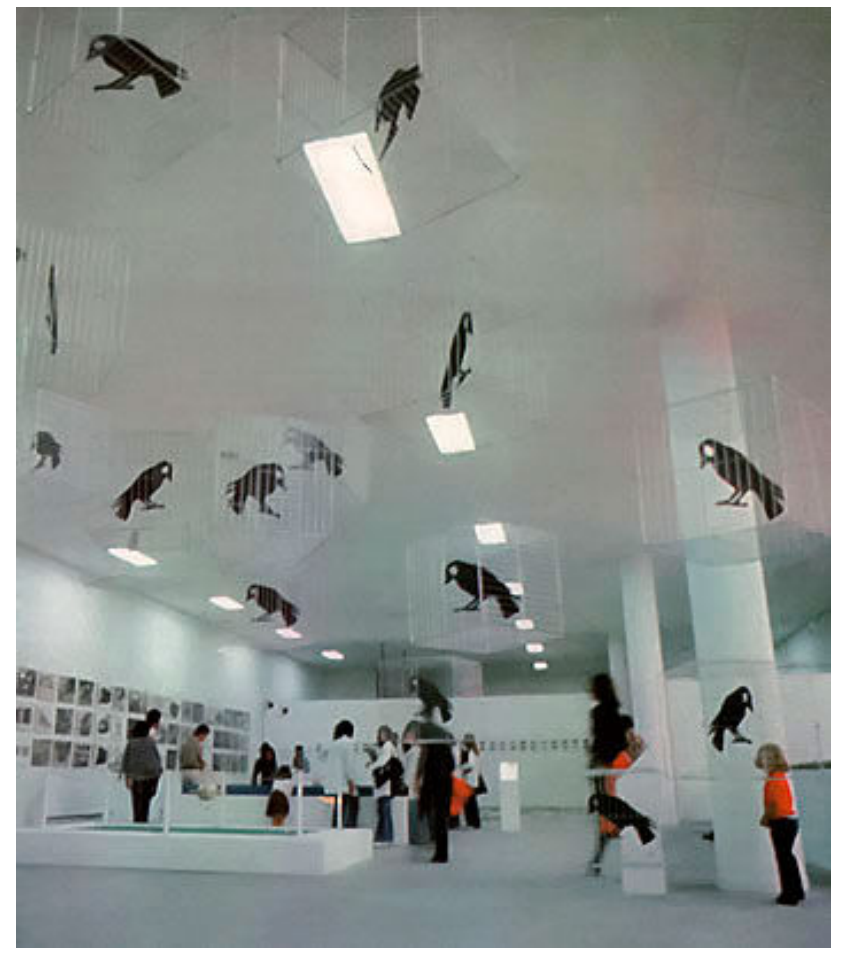

Figura 77 - Vista parcial da instalação Signos em Ecossistemas Artificiais. Detalhe da obra Factor Interespecífico, de Jorge González Mir.

XIV Bienal Internacional de São Paulo, 1977

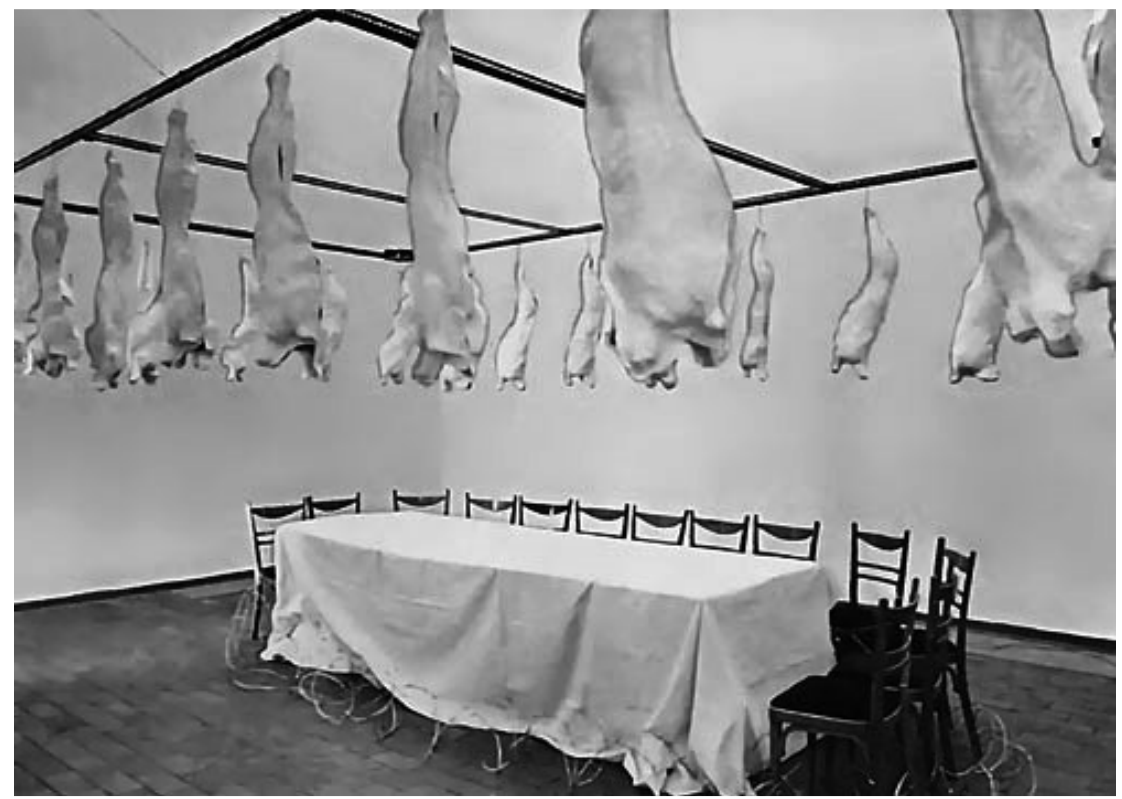

Figura 78 - Vista parcial da instalação La última cena, de Leopoldo Maler.

${ }^{212}$ Premiação da Bienal recebida com protestos. CARELLI, Wagner. O Estado de São Paulo. 12-10-1977. Arquivo Multimeios do Centro Cultural São Paulo. 
Por sua vez, os integrantes do Grupo de los Trece declararam que o prêmio de 12 mil e 500 dólares não cobriria o valor de aproximadamente 17 mil dólares investido por Jorge Glusberg para trazer as obras dos nove artistas envolvidos na instalação vencedora. O CAYC, entretanto, não participou oficialmente como representante da Argentina. Segundo o Conselho da Bienal, a Argentina recusou-se a participar da mostra por acreditar que "toda tendência moderna na arte denota a presença comunista" e que "não hastearia a bandeira argentina num pavilhão vermelho como a Bienal"213. A querela continuou nos bastidores da instituição e, especialmente, nos jornais, que deram destaque à polêmica premiação. O Jornal da Tarde divulgou uma matéria com a declaração de Alfredo Portillos e Jacques Bedel, do Grupo de los Trece, que se mostraram revoltados com "a falta de ética de Krajcberg”. E aproveitaram a ocasião para esclarecer os mal-entendidos:

"O grande prêmio não foi dado a um grupo de artistas improvisados, mas a um conjunto de propostas que tem nível e qualidade suficiente para aspirar ao prêmio. A proposta do CAYC é, há quase 10 anos, sensivelmente latino-americana e bem conhecida em todo o mundo. $\mathrm{O}$ CAYC não é um grupo de ricos, mas um grupo de profissionais que trabalha honestamente e com esforço. A prova é que três artistas não puderam viajar por falta de meios. O envio custou muito dinheiro e foi financiado pessoalmente por Glusberg, que não é um magnata, mas um crítico que se ocupa de promover a arte latino-americana e o faz com esforço próprio. Isso se deve ao fato do envio argentino não ter sido apoiado oficialmente. Teve que o ser de forma privada. O custo é alto porque há transporte, embalagem, seguros, um conjunto de obras de 9 artistas, coisas frágeis que tiveram de vir de avião. Não é a obra de um único artista, viajando pelo próprio país...". ${ }^{214}$

O Grupo de los Trece participou da proposição Arte Não-Catalogada, com a instalação Signos em Ecossistemas Artificiais. O conjunto de obras expostas reunia todas as tendências trabalhadas pelo Grupo desde o período de sua formação, representando, sem dúvida, um salto estético nas propostas auxiliadas pela arte de sistemas. Entretanto, esse trabalho se diferenciava do caráter simples e do uso de materiais baratos, típicos das exposições

\footnotetext{
${ }^{213}$ Premiação da Bienal recebida com protestos. CARELLI, Wagner. O Estado de São Paulo. 12-10-1977. Arquivo Multimeios do Centro Cultural São Paulo.

${ }^{214}$ A volta de Mário Pedrosa: "Afinal, quem Krajcberg julga que é? Um Deus? ” KLINTOWITZ, Jacob. Jornal da Tarde. 13-10-1977. Arquivo Multimeios do Centro Cultural São Paulo.
} 
organizadas pelo CAYC. O alto valor investido na montagem da instalação evidenciava a ambição de Glusberg em concorrer ao prêmio, a fim de comprovar a relevância da arte argentina ao mundo. Além disso, o discurso político que demarcava a categoria arte de sistemas já não era mais central, notando uma aproximação com as novas vertentes semióticas que começavam a circular na fortuna crítica daqueles anos (MARCHESI, 2013, p.81). De acordo com Glusberg, a instalação se vinculava não apenas às experiências da arte de sistemas, mas às tipologias urbanas da cidade, oferecendo uma visão sincrônica das construções humanas (GLUSBERG, 1985, p.221). E para abordar essa problemática, incluiu a dimensão ecológica ligada à construção dos "habitats humanos", propondo o conjunto de obras a partir dos polos natural - artificial.

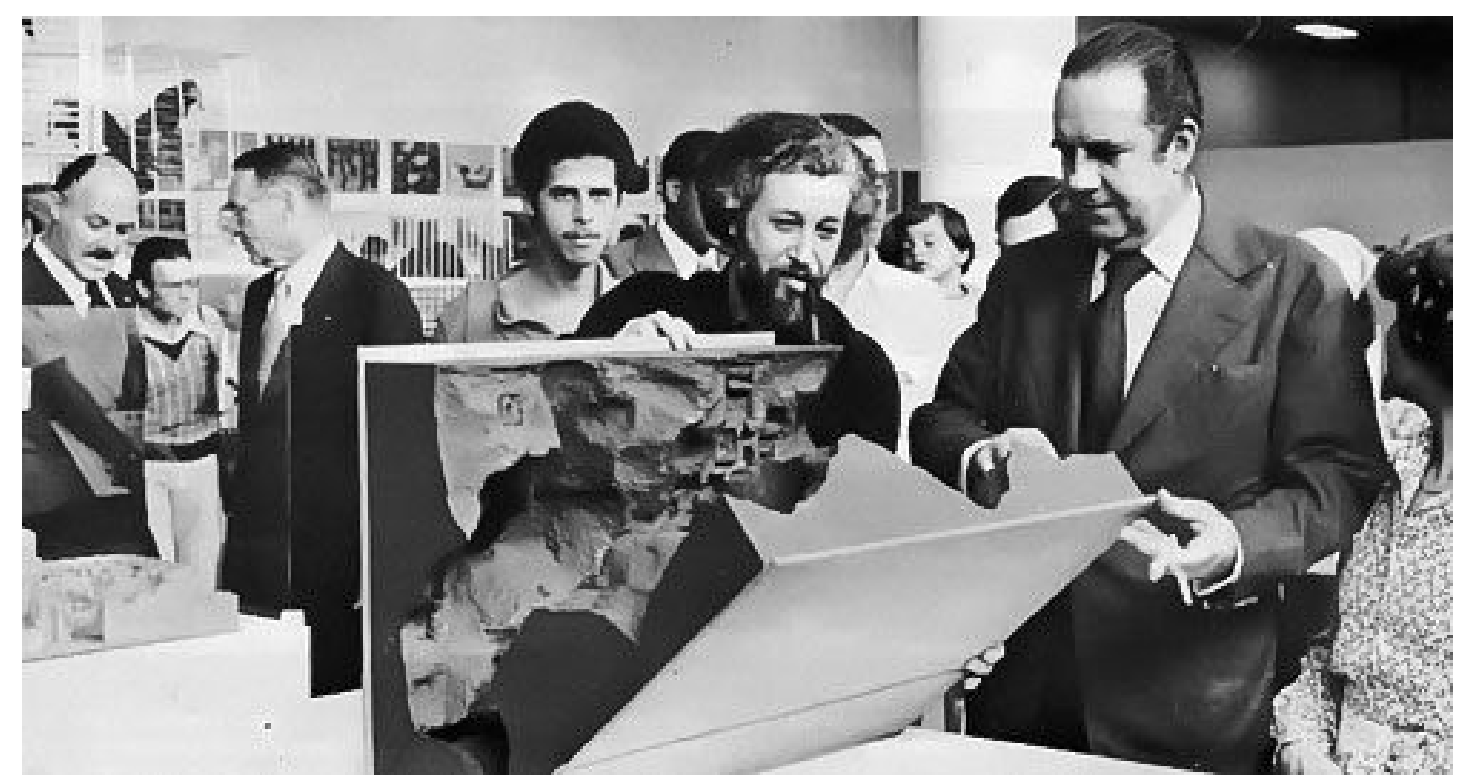

Figura 79 - Jorge Glusberg e o governador do Estado de São Paulo, Egydio Martins, diante da obra de Jacques Bedel.

XIV Bienal Internacional de São Paulo, 1977

Nosso recorte não procura focar na obra individual de cada integrante do Grupo de los Trece, mas sim refletir sobre o que estava em jogo nessa premiação, principalmente, a postura política incongruente de Jorge Glusberg. Um primeiro ponto importante que pode ampliar a compreensão desse contexto se associa ao interesse crescente pela temática regionalista e latino-americanista, debatida em várias conferências e simpósios desse período. Nesse sentido, a postura regional conduzida pelo CAYC, desde os primórdios da instituição, entraria em compasso com essas discussões que envolveram intelectuais e críticos como Juan Acha, Marta Traba, Néstor García Canclini, Damian Bayón, Aracy Amaral, Frederico Morais, entre 
outros. $^{215}$ A I Bienal Latino-americana, de 1978, é fruto dessas novas formulações teóricas sobre a produção cultural do continente. E como Jorge Glusberg estava sempre atento às oportunidades, não perdeu a chance de relacionar esse contexto com a produção ligada ao CAYC, conforme escrevera em um jornal portenho:

\begin{abstract}
"Signos en ecossistemas artificiales" y otras propuestas latinoamericanas exhibidas en la XIV Bienal nos permitieron deducir la certeza de una tesis que venimos esgrimiendo hace tempo: no existe un arte latinoamericano pero sí una problemática común. La nueva filosofia que inspiro la apertura de esta muestra paulista ha derivado en outra reforma essencial: entre cada Bienal Internacional se desarrollaba una Bienal Nacional; ahora, esta última sera substituída por Bienales Latinoamericanas, la primera de las cuales tendrá lugar en octubre de 1978. Como argentinos en particular, y como latinoamericanos en general, esta decisión nos parece fundamental, porque puede servir de vehículo a una idea esbozada por el CAYC en su primer catálogo, que data de 1969: la de estabelecer, como los europeus y los norteamericanos, un circuito de diálogo y difusión para el arte latinoamericano". ${ }^{216}$
\end{abstract}

Um segundo ponto que deve ser levado em conta se relaciona com a fácil mobilidade de Glusberg pelas instituições de seu país e no estrangeiro, e a coincidência do enrijecimento da ditadura militar com o êxito de seu Centro. O CAYC havia recusado participar das edições anteriores da Bienal, em consonância com a rede de artistas que estava formando os boicotes desde 1969. Todavia, a adesão de Glusberg à XIV Bienal soou contraditória, especialmente, em um momento que a Argentina era governada por um regime ditatorial. A imprensa brasileira também apontou as possíveis motivações políticas por trás da premiação, que poderiam favorecer o "país de regime amigo". ${ }^{217}$

\footnotetext{
${ }^{215}$ Sobre os simpósios e conferências sobre arte latino-americana desse período, ver: AMARAL, Aracy. Arte $\boldsymbol{e}$ meio artístico: entre a feijoada e o x-burguer. Artigos e Ensaios (1961-1981). São Paulo: Editora 34, 2013.

${ }^{216}$ Signos em Ecossistemas Artificiais e outras propostas latino-americanas exibidas na XIV Bienal nos permitiram chegar à certeza de uma tese que temos trabalho há tempos: não existe uma arte latino-americana, mas sim uma problemática comum. A nova filosofia que inspirou a abertura desta mostra paulistana tem derivado em outra reforma essencial: entre cada Bienal Internacional se desenvolvia uma Bienal Nacional; agora, esta última será substituída por Bienais Latino-americanas, a primeira das quais terá lugar em outubro de 1978. Como argentinos em particular, e como latino-americanos em geral, esta decisão nos parece fundamental, porque pode servir de veículo para uma ideia esboçada pelo CAYC em seu primeiro catálogo, que data de 1969: a de estabelecer, como os europeus e os norte-americanos, um circuito de diálogo e difusão para a arte latinoamericana. (tradução nossa). Bienal de San Pablo. GLUSBERG, Jorge. El Comercio. 13-11-1977. Arquivo Multimeios do Centro Cultural São Paulo.

${ }^{217}$ Premiação da Bienal recebida com protestos. CARELLI, Wagner. O Estado de São Paulo. 12-10-1977. Arquivo Multimeios do Centro Cultural São Paulo.
} 
Não restam dúvidas de que o CAYC e o Grupo de los Trece, direcionados para uma única figura, Jorge Glusberg, alcançaram o máximo reconhecimento e prestígio com o prêmio de um dos mais importantes eventos mundiais de arte, a Bienal Internacional de São Paulo. Com o êxito, a Argentina pretendia retomar a sua liderança continental depois de quase uma década de peregrinações pela América Latina e, sobretudo, pelo circuito internacional, promovendo o perfil da arte latino-americana. Na perspectiva de Glusberg, o que era válido para a Argentina era válido para todo o continente (MORAIS, 1979, p.175). A agilidade e a locomoção por diversos circuitos eram impulsionadas pelo objetivo de abrir as portas para a difusão da arte argentina pelo mundo. Entretanto, essa trajetória bem-sucedida do CAYC pode ser analisada sob outro ponto de vista. Vale mencionar a estratégia de Glusberg de dominação de diversos campos culturais do seu país. O perfil interdisciplinar do CAYC garantia certa versatilidade para inserir-se em diferentes áreas do conhecimento, assim como para vincular-se a entidades internacionais de ponta. Gradualmente, Glusberg desenvolveu uma atuação crítica múltipla, que abrangia toda a produção escrita dos catálogos e livros ligados ao CAYC, a direção de páginas de arquitetura e arte dos principais jornais do país ( $L a$ Opinión e Clarín) e artigos em publicações internacionais, divulgando o trabalho experimental do Centro e propondo uma leitura da arte inclinada com as propostas de suas exposições (CANCLINI, 2011, p.94). Após rebatar o grande prêmio da Bienal, Glusberg conseguiu trazer para a Argentina a vice-presidência da AICA (Associação Internacional de Críticos de Arte), na qual foi titular. Mas antes, o diretor sustentava o cargo de presidente da AACA (Associação Argentina de Críticos de Arte), do qual manteve controle permanente durante vários anos.

Mediante esse domínio de vários campos culturais (arte, arquitetura, imprensa, instituições associativas), e seus vínculos com forças econômicas e políticas, o CAYC conseguiu durante vinte anos uma assombrosa continuidade em um país onde um único governo constitucional conseguiu terminar seu mandato nas últimas quatro décadas. Também parece uma consequência de seu controle sobre tantas instâncias da produção e da circulação artística que esse centro não tenha recebido mais do que críticas confidenciais, nenhuma que o questionasse seriamente a ponto de diminuir seu reconhecimento no país. (CANCLINI, 2011, p.94).

Mas o ponto mais controverso da personalidade de Glusberg foi a relação estreita que manteve com a ditadura militar argentina (1976-1983). Sabemos que o Centro era uma 
instituição privada, cujo financiamento vinha de uma das maiores empresas de artigos de iluminação da Argentina, a Modulador, da qual Glusberg era herdeiro. Parte da verba gerada pela corporação era de contratos com o governo militar, um dos seus principais clientes. A Modulador, por exemplo, iluminou os estádios da Copa do Mundo de Futebol, de 1978, quando a Argentina foi anfitriã do evento. Nessa época, o general Rafael Videla estruturava uma campanha política que nomeava os argentinos de "direitos" e "humanos", procurando responder às denúncias internacionais por sua violação aos direitos humanos (CAMNITZER, 2008, p.397). Na ocasião do grande prêmio da XIV Bienal Internacional de São Paulo, o Grupo de los Trece recebeu um telegrama do presidente Videla parabenizando-o pela enorme conquista. A imprensa local divulgou alguns trechos da carta enviada ao Grupo, nos quais o general mandava as mais "calorosas felicitações" pela premiação, reiterando o mais alto nível da arte argentina e a variedade enriquecedora de suas propostas estéticas ${ }^{218}$. Glusberg, por sua vez, respondeu ao presidente, comprometendo-se com ele a "representar o humanismo da arte argentina no exterior" (CANCLINI, 2011, p.95).

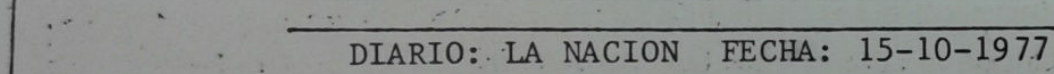 \\ Felicitó Videla a los premiados en San Pablo \\ El presidente de la Repúbli- El jefe del Estado le seffala mismo modo, premia y estimu- lauro reitera, una vez más. ef $\mathrm{ca}$ envió un telegrama de feli- que "esta distinción destaca el la a la creatividad y al traba- alto aivel dej arte argentino y citación al Grupo de los 13, que logro alacanzado en las bús- jo tesonero y metćdico, condi- la variedad enriquécedora de

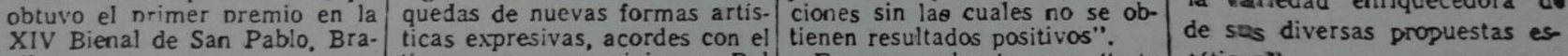

Sobre essa questão controversa, Frederico Morais (1979) levantou a seguinte pergunta: como conciliar criação e repressão? Se a arte argentina, e por extensão latino-americana, recuperou o seu prestígio, parte dessa guinada foi tributária da inteligência e agilidade de Jorge Glusberg, que soube aproveitar o talento indiscutível dos artistas ligados ao Grupo de los Trece, assim como estes se valeram da máquina promocional do CAYC para divulgar seus trabalhos. Até certo ponto, todos poderiam ganhar nessa cooperação. Entretanto, segundo o

${ }^{218}$ Felicitó Videla a los premiados en San Pablo. La Nación. 15-10-1977. Arquivo Multimeios do Centro Cultural São Paulo. 
crítico, "todo o organismo que cresce muito, e rapidamente, cria o seu próprio câncer", levando a outro questionamento: "por que a Argentina entregou a Glusberg, momentaneamente, o comando de um de seus setores culturais, as artes plásticas"? (MORAIS, 1979, p.177). Essas perguntas nos levam à reflexão sobre como conciliar os processos de criação artística em países nos quais o regime político é de exceção, que nesse momento era vigente em quase toda a região do cone sul. A história do CAYC (1968-1994), que durou mais de 20 anos, foi simultânea a uma sucessão de governos, crises políticas e econômicas, golpes militares e do retorno à democracia. Ainda assim, a instituição prosseguiu estável dentro dessa conjuntura incerta. A atuação de seu diretor, apoiada por influências durante a ditadura e estratégicas alianças internacionais, o permitiu desfrutar de um poder irrestrito no campo das artes visuais e da arquitetura. E por tentar conciliar o que é irreconciliável, Jorge Glusberg, pouco a pouco, perdeu o seu espaço na história da arte latinoamericana. Embora ainda mantivesse sob a sua órbita cargos importantes, como a gestão ${ }^{219}$ do Museu Nacional de Belas Artes de Buenos Aires (1994-2003), Glusberg acabou afastado dos grandes relatos, sobretudo, da arte conceitual latino-americana, que em décadas anteriores fora a sua ponta de lança.

\footnotetext{
${ }^{219}$ A sua direção foi envolvida em diversos escândalos, como superfaturamento da impressão de catálogos, maus tratos aos funcionários e até furto de obras. Após diversas mobilizações, entre protestos e abaixo-assinados, Glusberg renunciou ao cargo, em 2003, depois de quase dez anos de gestão. Sobre essa polêmica, ver: Los expedientes Glusberg. In: http://www.ramona.org.ar/files/r38.pdf. Acesso no dia 21-07-2015
} 


\section{CONSIDERAÇÕES FINAIS}

As décadas de 1960 e 1970 foram de intensas transformações tanto no âmbito artístico como no político. As artes visuais passaram pela tarefa de recusa das convenções que representou o questionamento do sistema artístico e da unicidade da obra de arte, a inclusão de materiais não tradicionais, a valorização da criação coletiva, entre outros, permitindo que essas práticas desenvolvessem cada vez mais uma atuação social e política efetiva. Embora ainda não houvesse um mercado de arte consolidado, esses grupos de artistas pesquisados neste trabalho, também passaram a produzir dentro de uma concepção contrária à lógica comercial, propondo formas alternativas de circulação, em especial, durante a década de 1970. O acento político que caracterizou parte das obras analisadas foi marcado pelo contexto de adversidades, coincidindo com a ascensão das ditaduras militares na região do cone sul.

Entretanto, para compreender de um modo mais amplo esse período, iniciamos a nossa leitura em um momento anterior, assinalado pela criação e importação de projetos de modernização para a América Latina, após a Segunda Guerra Mundial. O crescimento econômico registrado no âmbito local gerou uma série de políticas de desenvolvimento e de renovação no campo das artes visuais. Vimos que para alcançar o fôlego das grandes metrópoles, a fim de romper com o isolamento, as capitais avaliadas (Buenos Aires e São Paulo) buscaram o apoio e financiamento de entidades e empresas multinacionais. A fundação de um novo aparato institucional moderno foi fruto dessas alianças políticas, que incluiu a atualização das linguagens artísticas, representada pela arte abstrata, e a concepção museológica do MoMA, como espaço privilegiado de exibição de arte moderna.

Nesse contexto, fora inaugurado os Museu de Arte Moderna e a Bienal Internacional de São Paulo, transferindo ao Brasil o protagonismo cultural dentro da trama regional. Se a arte concreta que aproximou, de forma particular, "os artistas brasileiros de seus colegas argentinos", é "indubitável que foram as Bienais de São Paulo que constituíram a vitrine de todas as tendências da arte argentina a partir dos anos 50" (AMARAL, 2006, p.171). Sem dúvidas, a Bienal de São Paulo constituiu-se como órgão essencial para a internacionalização da arte, que "copiando y compitiendo con la Bienal de Veneza, fue un instrumento diseñado 
para atraer arte internacional hacia América Latina" (CAMNITZER, 2008, p.316) ${ }^{220}$. Essa política teria continuidade nos programas desenvolvidos pelo Instituto Torcuato Di Tella e pelo CAYC, posteriormente.

A Argentina consolidou um modelo específico de mecenato que deu origem ao $\mathrm{Di}$ Tella, instituição central de nosso estudo. Por meio dessa instituição, buscamos problematizar as estratégias concebidas para internacionalizar a arte local, em busca de reconhecimento e de um intercâmbio mais igualitário com os grandes circuitos artísticos. Nos anos de 1960, uma entidade como o Di Tella, por meio de Romero Brest, havia atingido um alto grau de institucionalização, gerando condições favoráveis para promover uma arte de vanguarda que estivesse no mesmo pé de igualdade das produções de ponta da Europa e, especialmente, dos EUA. Contudo, contra todos os prognósticos que asseguraram o êxito do internacionalismo, restou à vanguarda argentina a batalha pelo reconhecimento local. Culturalmente reacionárias, as autoridades políticas não podiam permitir um espaço de livre criação tal como fora o Di Tella. Tampouco, a recepção crítica foi partidária, demostrando dificuldade em reconhecer e defender a arte argentina. As condições para o triunfo internacional não conseguiram se sustentar em um cenário instável caracterizado pela crise econômica, política e militar.

A produção desse período pode ser entendida como uma reação aos modelos artísticos vinculados aos projetos de modernização implantados na região, durante a Guerra Fria. O fracasso dessas alianças políticas e econômicas diluíram a chance de conceber um projeto eficaz de desenvolvimento gradual na América Latina. Soma-se a esse plano de modernização frustrado, o temor da expansão da revolução cubana para outras áreas do continente. Diante dessa situação incerta, não restou ao governo norte-americano buscar novos aliados: "no ya políticos vulnerables, ni representantes de las nuevas burguesias industriales [...], sino los militares y las dictaduras que dominaron el sistema político latinoamericano" (GIUNTA, 2008$, p.301 $)^{221}$. A crescente radicalização política no campo cultural, além da adesão aos princípios revolucionários, proporcionou meios para unir a vanguarda artística e a vanguarda política. Vimos que esse projeto utópico marcou os movimentos artísticos no final da década de 1960 na Argentina, sobretudo, após a mostra Experiencias 68 e a manifestação Tucumán Arde.

\footnotetext{
220 "copiando e competindo com a Bienal de Veneza, foi um instrumento desenhando para atrair a arte internacional para a América Latina". (tradução nossa).

221 "não mais políticos vulneráveis, nem representantes das novas burguesias industriais, mas os militares e as ditaduras que dominaram o sistema político latino-americano". (tradução nossa).
} 
A década seguinte foi protagonizada pelo CAYC, principal difusor das práticas experimentais na Argentina, cuja ponta de lança fora o estímulo à arte conceitual. Jorge Glusberg soube como ninguém se apropriar de movimentos artísticos estrangeiros e adaptálos às condições locais. Vimos que o termo arte de sistemas e as produções voltadas ao conceitualismo ideológico foram versões da linguagem internacional da arte conceitual contornadas por um viés ideológico e político regional. A dialética de um discurso internacionalista e regionalista moldaram as estratégias do Centro de Arte y Comunicación, que ao mesmo tempo se apoiaram em uma proposta local, traçando um perfil da arte latinoamericana, impulsionada para o estrangeiro. Se observamos uma primeira tentativa, por parte de Romero Brest, de garantir à arte argentina o mérito e reconhecimento pelos grandes circuitos, foi Jorge Glusberg quem definitivamente consolidou essa ambição, cujo ápice foi a premiação da XIV Bienal Internacional de São Paulo.

Estruturado em uma campanha enérgica de publicidade, o CAYC difundiu pelo mundo as conhecidas gacetillas amarillas, com a programação de exposições, conferências, textos de artistas e intelectuais convidados pelo Centro. Além disso, padronizou um formato de exposições heliográficas que podiam ser facilmente montadas em qualquer lugar e aderidas por um número amplo de expositores, sobretudo de artistas de renome internacional, abrindo um espaço privilegiado para a circulação das propostas amparadas pela instituição. A criação do Grupo de los Trece foi mais uma tática para divulgar as proposições ligadas à categoria arte de sistemas, que buscava reconhecer as mesmas condições objetivas através da produção de um modelo conceitual. "Este modelo permite entonces, a partir de cada discurso artístico, analizar [...] los códigos a los que se integra, y [...] lograr uma integración conceptual que denominamos arte de sistemas". 222

A ágil mobilidade por circuitos em seu país e no exterior, as alianças internacionais e os contatos com a ditadura, possibilitaram a Glusberg um poder irrestrito no campo das artes visuais. Essas alianças estiveram focadas em instituições hegemônicas da Europa e dos EUA, entretanto, o CAYC buscou efetivar acordos com entidades latino-americanas. Nosso recorte se debruçou no diálogo instituído entre o diretor portenho e Walter Zanini, que na época estava à frente do MAC USP. Ambas as instituições compartilharam o interesse pelas novas

\footnotetext{
222 "Este modelo permite, a partir de cada discurso artístico, analisar [...] os códigos aos quais se integra, e [...] conseguir uma integração conceitual que denominamos arte de sistemas". (tradução nossa). GLUSBERG, Jorge. Diálogo versus colonización artística. In: ROSSI, Cristna; DOLINKO, Silvia; AMIGO, Roberto. Palabra de artista. Textos sobre arte argentino, 1961-1981. Buenos Aires: Fondo Nacional de las Artes - Fundación Espigas, 2010.
} 
tecnologias e pelo intercâmbio de exposições, além de tornarem-se pontos referenciais das práticas experimentais no continente sul-americano, partilhando um perfil de locais abertos para a realização de proposições de caráter mais conceitual. Para analisar esse diálogo institucional, decidimos focar na história das exposições como meio fértil de conhecermos a dinâmica do sistema da arte, para além do estudo de obras e artistas isoladamente. (FREIRE, 2013, p.15). Para tanto, levamos em conta as variáveis políticas, econômicas e institucionais que mobilizaram esses micro-relatos, buscando compreender os perfis de Zanini e Glusberg dentro desse contexto mais amplo.

A produção argentina nunca buscou esconder a vocação cosmopolita da sua arte, simultaneamente a um esforço por caracterizar a sua peculiaridade "ou, pelo menos, a originalidade dos desdobramentos que sofrem, no país, as tendências internacionais" (MORAIS, 1979, p.175). Glusberg, nesse sentido, deu continuidade a uma tradição local, adaptando os modelos de arte conceitual às particularidades da arte de sistemas ou de um conceitualismo ideológico em busca de um lugar hegemônico ou mainstream. O CAYC buscou a qualquer custo integrar os artistas argentinos e latino-americanos dentro desse circuito, por meio de estratégias bastante questionáveis, como vimos a respeito da relação estreita que o seu diretor manteve com o regime militar. De acordo com Luis Camnitzer,

dada la concentración en la autopromoción y la asimilación, lo que pudo haber sido un programa serio de exposiciones equilibradas y ecléticas se redujo a recoger los câmbios de moda en el mainstream para acomodarse con oportunismo. La idea de Glusberg era que el mainstream era una cualidad contagiosa que se transmitiría a sus artistas si éstos tenían contacto con los grandes nombres internacionales (CAMNITZER, 2008, p.314). ${ }^{223}$

E desse modo, podemos chegar à uma breve conclusão. Se Glusberg e Zanini partilharam diversas afinidades, conformando o CAYC e o MAC USP como lugares possíveis de acolhimento e como promotores da vanguarda internacional, suas estratégias para essa empreitada foram bastante distintas. Enquanto o Centro portenho estava focado na internacionalização da arte argentina, por meio de alianças táticas com os grandes circuitos, o MAC USP buscava ativar uma intensa rede internacional, por meio da arte postal e demais

\footnotetext{
223 "Dada a concentração na auto-promoção e na assimilação, o que poderia ter sido um programa sério de exposições equilibradas e ecléticas se reduziu a uma acomodação das transformações da moda no mainstream como uma qualidade contagiosa que se transmitiria aos seus artistas, se estes tivessem contato com os grandes nomes internacionais". (tradução nossa).
} 
práticas multimídias, fora do sistema oficial e hegemônico. "Os envios postais de trabalhos artísticos são tomados como estratégia distante do mercado e do poder, capazes de abrir outros circuitos de intercâmbio e inaugurar cartografias diferentes para mostras, apesar da censura política e das limitações econômicas" (FREIRE, 2013, p.10). Além disso, o Museu, amparado nas relações de amizade e confiança, tornou-se um território livre para o encontro e o diálogo de artistas.

Por meio de um campo simbólico de disputas políticas, culturais e econômicas pelo protagonismo na região, procuramos traçar as trajetórias ora tangenciais, ora divergentes, estabelecidas entre Brasil e Argentina, ao longo das décadas de 1960 e 1970. A compreensão dessa trama de intercâmbios artísticos e institucionais permitiu um outro ângulo sobre esse período no qual sedimentou-se uma nova visualidade. E, sobretudo, possibilitou o entendimento de uma parte da produção artística latino-americana, ampliando a visão sobre as práticas desenvolvidas no continente. Investigar o trânsito do conceitualismo brasileiro e argentino, suscitou uma rica oportunidade de conhecer os países vizinhos, na chave do que o crítico Frederico Morais certa vez escrevera: "Brasil e América Latina começam a se conhecer. Cresce a consciência de que temos de caminhar juntos, pensarmos juntos a nossa realidade" (MORAIS, 1979, p.13). 


\section{REFERÊNCIAS BIBLIOGRÁFICAS}

ALAMBERT, Francisco; CANHÊTE, Polyana. As Bienais de São Paulo: da era do Museu à era dos curadores (1951-2001). São Paulo: Boitempo Editorial, 2004.

ALONSO, Rodrigo. Sistemas, acciones y procesos 1965-1975. Buenos Aires: Fund. PROA, 2011.

AMARAL, Aracy (Org.). Expo Projeção 73. São Paulo: Centro de Arte Novo Mundo, 1976.

\section{Expo Projeção 73.}

In: http://expoprojecao.com.br/_pdf/expo_catalogo.pdf. Acesso em: 20-07-2015.

(Org.). Projeto construtivo brasileiro na arte (1950-1962). Rio de Janeiro: Museu de Arte Moderna, São Paulo: Pinacoteca do Estado, 1977.

(Org.). MAC USP: perfil de um acervo. São Paulo: Techint Engenharia SA, 1988.

Textos do Trópico de Capricórnio. Artigos e ensaios (1980-2005). V. 2: Circuitos de arte na América Latina. São Paulo: Editora 34, 2006.

Arte e meio artístico: entre a feijoada e o x-burguer. Artigos e Ensaios (1961-1981). São Paulo: Editora 34, 2013.

AMARANTE, Leonor. As Bienais de São Paulo. 1951-1987. São Paulo: BFB Projeto, 1989.

BALDASARRE, María Isabel; DOLINKO, Silvia (Eds.). Travesías de la imagen. Historias de las artes visuales en la Argentina. Buenos Aires, Centro Argentino de Investigadores de Artes (CAIA); Sáenz Peña: Universidad Nacional Tres de Febrero, 2012.

BREST, Romero Jorge. Arte visual en el Di Tella. Aventura memorable en los años 60 . Buenos Aires: Emecé Editores, 1992. 
. Relación y reflexión sobre el Pop Art. In: KATZENSTEIN, Inés (Ed.). Escritos de vanguardia. Arte argentino de los años 60. Buenos Aires: Fundación Espigas, 2007.

BÜRGUER, Peter. Teoria das vanguardas. São Paulo: Cosac Naify, 2008.

BURNHAM, Jack. Systems Esthetics. In: Revista Artforum. Nova Iorque, set. 1968.

BRITO, Ronaldo. As ideologias construtivas no ambiente cultural brasileiro. In: AMARAL, Aracy (Org.). Projeto construtivo brasileiro na arte (1950-1962). Rio de Janeiro: Museu de Arte Moderna; São Paulo: Pinacoteca do Estado, 1977.

CAMNITZER, Luis. Didácticas de la liberación: arte conceptualista latinoamericano. Montevideo: Casa Editorial HUM, 2008.

CANCLINI, Néstor García. A produção simbólica - Teoria e metodologia em sociologia da arte. Rio de Janeiro: Ed. Civilização Brasileira, 1979.

A socialização da arte - Teoria e prática na América Latina. São Paulo: Ed. Pensamento, 1984.

Culturas híbridas. São Paulo: Edusp, 2011.

CANONGIA, Ligia. O legado dos anos 60 e 70. Rio de Janeiro: Jorge Zahar Ed., 2005.

CELANT, Germano. Arte Povera. Apuntes para una guerrilla. In: ALONSO, Rodrigo. Sistemas, acciones y procesos. 1965-1975. Buenos Aires: Fund. Proa, 2011.

COSTA, Eduardo; ESCARI, Raúl; JACOBY, Roberto. Un arte de los medios de Comunicación (Manifiesto). In: ALONSO, Rodrigo. Sistemas, acciones y procesos. 19651975. Buenos Aires: Fund. Proa, 2011.

D'AGUIAR, Rosa Freire (Org.). Essencial Celso Furtado. São Paulo: Penguin Classics Companhia das Letras, 2013. 
DANTO, Arthur C. Após o fim da arte: a arte contemporânea e os limites da história. São Paulo: Odysseus Editora, 2006.

DAVIS, Fernando; HERRERA, Maria José; PERRET, Danielle. Horacio Zabala. Anteproyectos (1972-1978). Buenos Aires: Editorial Fundación Alón, 2007.

. Un máximo de posibilidades con un mínimo de recursos. In: Horacio Zabala: 300 metros de cinta negra para enlutar una plaza pública - 1972/2012. Buenos Aires: Otra Cosa, 2012.

; ROMERO, Juan Carlos; LONGONI, Ana. Romero. Buenos Aires: Fundación Espigas, 2010.

; El Conceptualismo como categoría Táctica. Revista Ramona.

http://www.ramona.org.ar/node/21556._Acesso em 07 Jun. 2015

Luis Pazos, el fabricante de modos de vida: acciones, cuerpo, poesía. Buenos Aires: Document Art, 2014.

DOLINKO, Silvia, Representación, lenguajes y discursos artísticos. In: ROSSI, Cristina; DOLINKO, Silvia; AMIGO. Roberto. Palabra de artista. Textos sobre arte argentino, 19611981. Buenos Aires: Fondo Nacional de las Artes - Fundación Espigas, 2010.

FIZ, Simón Marchan. Del arte objectual al arte de concepto - Las artes plasticas desde 1960. Madrid: Plaza Mayor, 1972.

Del arte objectual al arte de concepto (1960-1974) - Epílogo sobre la sensibilidad “postmoderna”. Antología de escritos y manifiestos. 10. ed. Madri: Ediciones Akal, 1986.

FOSTER, Hal. O retorno do real: a vanguarda no final do século XX. São Paulo: Cosac Naify, 2014. 
FREIRE, Cristina. Poéticas do processo. Arte conceitual no museu. São Paulo: Ed. Iluminuras, 1999.

. Arte conceitual. Rio de Janeiro: Jorge Zahar Editor, 2006.

; LONGONI, Ana (Orgs.). Conceitualismos do Sul/Sur. São Paulo: Annablume Editora, 2009.

. Apuentes sobre el arte subterrâneo en Latinoamerica en los años 1960-1970. In: ALONSO, Rodrigo. Sistemas, acciones y procesos. 1965-1975. Buenos Aires: Fund. PROA, 2011 .

La red en exposición: Prospectiva 74. Revista Índex.

In: http://www.macba.cat/uploads/20111122/02_cas.pdf. Acesso em 20 jul. 2015.

(Org.). Hervé Fischer no MAC USP: arte sociológica e conexões: arte-sociedadearte-vida. São Paulo: Museu de Arte Contemporânea da Universidade de São Paulo MAC USP, 2012.

(Org.). A cidade e o estrangeiro: Isidoro Valcarcel Medina. São Paulo: Museu de Arte Contemporânea da Universidade de São Paulo - MAC USP, 2012.

(Org.). Walter Zanini: escrituras críticas. São Paulo: Annablume; São Paulo: Museu de Arte Contemporânea da Universidade de São Paulo - MAC USP, 2013.

(Org.). Terra incógnita. Conceitualismos da América Latina no acervo do MAC USP. São Paulo: Museu de Arte Contemporânea da Universidade de São Paulo - MAC USP, 2015.

FREITAS, Artur. Arte de guerrilha. Vanguarda e conceitualismo no Brasil. São Paulo: Edusp, 2013. 
GARCÍA, Maria Amalia. La construcción del arte abstracto. In: GARCÍA, Maria Amalia; SERVIDDIO, Fabiana; ROSSI, Cristina María. Arte argentino y latinoamericano del siglo XX. Buenos Aires: Fundación Espigas, 2004.

. Abstracción entre Argentina y Brasil: inscripción regional e interconexiones del arte concreto (1944-1960). Tese de Doutorado. Universidad de Buenos Aires, Buenos Aires, 2008.

GIUNTA, ANDREA. Vanguardia, internacionalismo y política: arte argentino en los años 60. Buenos Aires: Siglo XXI, 2008.

. Imaginarios de la desestabilización. In: ALONSO, Rodrigo. Sistemas, acciones y proceso. 1965-1975. Buenos Aires: Fund. Proa, 2011.

; COSTA, Laura Malosetti (Org.) Arte de posguerra - Jorge Romero Brest y la revista Ver y Estimar. Buenos Aires: Editorial Paidós, 2005.

. Utopía y disolución: Arte crítico en la década del sesenta. In: Artes plásticas na América Latina contemporânea. BULHÕES, Maria Amélia; KERN, Maria Lúcia Bastos [Org.]. Porto Alegre: Ed. Da Universidade-UFRGS, 1994.

GLUSBERG, Jorge. Argentina Inter-medios (cat. exp.). Buenos Aires: CAYC, 1969.

Arte y cibernética (cat. exp). Buenos Aires: Galeria Bonino, 1969.

De la figuración al arte de sistemas (cat. exp). Córdoba: Museo Provincial de Bellas Artes Emilio Caraffa, 1970.

; LIPPARD, Lucy. 2.972.453 (cat. exp). Buenos Aires: CAYC, 1970.

Arte de sistemas (cat. exp). Buenos Aires: Museu de Arte Moderno, 1971.

Hacia um perfil del arte latinoamericano (cat. exp). Buenos Aires: CAYC, 1971. 
. Joseph Kosuth - El arte como idea (cat. exp). Buenos Aires: CAYC, 1971.

. Arte de Sistemas II - CAYC al aire libre. Arte e ideologia. (cat. exp). Buenos Aires: CAYC, 1972.

. Decada del 70. (cat. exp). Ciudad Universitaria, Mexico: Museo Universitario de Ciencias y Artes, 1977.

. Retórica del arte latinoamericano. Buenos Aires: Ediciones Nueva Visión, 1978.

Del pop-art a la nueva imagen. Buenos Aires: Ediciones de Arte Gaglianone, 1985.

GREENBERG, Clement. Pintura modernista. In: COTRIM, Cecília e FERREIRA, Glória [Org.]. Clement Greenberg e o debate crítico. Rio de Janeiro: Jorge Zahar Editor, 1997.

GRIPPO, Victor. Sistemas. In: Escritos de artistas: anos 60-70. CONTRIM, Cecília; FERREIRA, Glória (Org.). Rio de Janeiro: Jorge Zahar Ed., 2006.

HERRERA, María José. POP! La consagración de la primavera. Buenos Aires: Fundación OSDE, 2010.

; MARCHESI, Mariana. Arte de sistemas: el CAYC y el proyecto de un nuevo arte regional. 1969 - 1977. Buenos Aires: Fundación OSDE, 2013.

. La experimentación con los medios masivos de Comunicación en el arte argentino de la decada del sesenta: el "happening para un jabalí difunto". In: http://www.caia.org.ar/docs/Herrera.pdf. Acesso em 21 maio. 2105.

HERKENHOFF, Paulo. A Bienal de São Paulo e seus compromissos culturais e políticos. In: Revista USP, São Paulo, no 52, dez. 2001/fev. 2002. 
HUYSSEN, Andreas. Culturas do passado-presente: modernismos, artes visuais, políticas da memória. Rio de Janeiro: Contraponto; Museu de Arte do Rio, 2014.

IANNI, Octavio. A sociedade global. Rio de janeiro: Civilização Brasileira, 1995.

JAMESON, Frederic. Pós-modernismo: a lógica cultural do capitalismo tardio. São Paulo: Ática, 2004.

JAREMTCHUK, Dária. Jovem Arte Contemporânea no MAC USP. Dissertação de Mestrado. Escola de Comunicações e Artes, Universidade de São Paulo, São Paulo, 1999.

JAREMTCHUK, Dária. Anna Bella Geiger: passagens conceituais. São Paulo: Edusp. Belo Horizonte: C Arte, 2007.

KATZENSTEIN, Inés (Ed.). Escritos de vanguardia. Arte argentino de los años 60 . Buenos Aires: Fundación Espigas, 2007.

KING, John. EI Di Tella. Buenos Aires: Asunto Impreso Ediciones, 2007.

Di Tella y el desarrollo cultural argentino em la década del sesenta. Buenos Aires: Ediciones Gaglianone, 1985.

KOSUTH, Joseph. Arte após a filosofia. In: CONTRIM, Cecília; FERREIRA, Glória (Orgs.). Escritos de artistas: anos 60-70. Rio de Janeiro: Jorge Zahar Ed., 2006.

LANDER, Edgardo (Org.). La colonialidad del saber: Eurocentrismo y ciencias sociales. Perspectivas latinoamericanas. Buenos Aires: CLACSO, 2010.

LIPPARD, Lucy; CHANDLER, John. La desmaterialización del arte. In: ALONSO, Rodrigo (Org.). Sistemas, acciones y procesos. 1965-1975. Buenos Aires: Fund. Proa, 2011. 
LONGONI, Ana; MESTMAN, Mariano. Del Di Tella a "Tucumán Arde": vanguardia artística y política en el 68 argentino. Buenos Aires: Editorial Universitaria de Buenos Aires, 2008.

LÓPEZ, Anaya Jorge. Historia del arte argentino. Buenos Aires: Emecé, 1997.

LOURENÇO, Maria Cecília. Museus acolhem o moderno. São Paulo: Edusp, 1999

LOUZADA, Heloisa. Contrastes na cena artística paulistana: MAC USP e MAM SP nos anos 1970. Dissertação de Mestrado. Programa de Pós-Graduação Interunidades em Estética e História da Arte, Universidade de São Paulo, São Paulo, 2013.

MARCHESI, Mariana; RICCARDI, Teresa. MNBA - CAYC, 1969-1983: dos alternativas institucionales en la promoción del arte argentino. In: BALDASARRE, María Isabel, DOLINKO, Silvia [Org.]. Travesías de la imagen. Historias de las artes visuales en la Argentina. Buenos Aires: Sáenz Peña: Universidad Nacional Tres de Febrero, 2012.

MASOTTA, Oscar. Prólogo a happenings. In: KATZENSTEIN, Inés (Ed.). Escritos de vanguardia. Arte argentino de los años 60. Buenos Aires: Fundación Espigas, 2007.

. Sobre happenings, happening: reflexiones y relatos. In: KATZENSTEIN, Inés (Ed.). Escritos de vanguardia. Arte argentino de los años 60. Buenos Aires: Fundación Espigas, 2007.

. Después del pop, nosotros desmaterializamos. In: ALONSO, Rodrigo. Sistemas, acciones y procesos. 1965-1975. Buenos Aires: Fund. Proa, 2011.

MINUJíN, Marta. Marta Minujín: obras 1959-1989. Buenos Aires|: Malba, 2010.

MORAIS, Frederico. Artes plásticas na América Latina: do transe ao transitório. Rio de Janeiro: Editora Civilização Brasileira, 1979.

Artes plásticas: a crise da hora atual. Rio de Janeiro: Editora Paz e Terra, 1975. 
. Do corpo à terra (1987). In: SEFFRIN, Silvana (Org.). Frederico Morais. Rio de Janeiro: FUNARTE, 2004.

MIGNOLO, Walter. Espacios geográficos y localizaciones epistemológicas: la ratio entre la localización geográfica y la subalternización de conocimientos. In: Estudios: Revista de Investigaciones Literarias y Culturales. Caracas, v. 6, n.11, jan. 1998.

NOORTHOORN, Victoria; PELLA, Jimena Ferreiro; VILLA, Javier. Marta Minujín: obras 1959-1989. Buenos Aires: Fundación Eduardo F. Constantini, 2010.

O’DOHERTY, Brian. No interior do cubo branco: a ideologia do espaço da arte. São Paulo: Ed. Martins Fontes, 2002.

PACHECO, Marcelo. De lo moderno a lo contemporáneo. Tránsitos del arte argentino 19581965. In: KATZENSTEIN, Inés (Ed.). Escritos de vanguardia. Arte argentino de los años 60. Buenos Aires: Fundación Espigas, 2007.

PERAZZO, Nelly. Las vanguardias constructivas en la Argentina. In: BELLUZZO, Ana Modernidade: vanguardas artísticas na América Latina. São Paulo: Editora Unesp, 1990.

PINEAU, Natalia. EI CAYC: la reconstrucción de un programa institucional. In: ICAA Documents Project Working Papers. The Publication Series for Documents of 20th-Century Latin American and Latino Art. Houston, The International Center for the Arts of the Americas - The Museum of Fine Arts, n. 1, 2007. [consultado no site do ICCA Documents]

RAMÍREZ, Mari Carmen. Circuito de heliografias: arte conceitual e política na América Latina. In: Revista do Programa de Pós-graduação em Artes Visuais. EBA, UFRJ. Ano VII, n. 8, 2001.

RANCIÈRE, Jacques. A partilha do sensível. São Paulo: Editora 34, 2009 
RIBEIRO, Marília Andrés. A arte não pertence a ninguém. In: Revista UFMG, Belo Horizonte, v. 20, n. 1, jan./jun. 2013.

RIZZO, Patricia. Instituto Di Tella. Experiencias 68. Buenos Aires: Fundación Proa, 1998.

ROLNIK, Suely. Desentranhando futuros. In: FREIRE, Cristina; LONGONI, Ana (Orgs.). Conceitualismos do Sul/Sur. São Paulo: Annablume Editora, 2009.

ROSSI, Cristna; DOLINKO, Silvia; AMIGO, Roberto. Palabra de artista. Textos sobre arte argentino, 1961-1981. Buenos Aires: Fondo Nacional de las Artes - Fundación Espigas, 2010.

SANTOS, Milton. O espaço do cidadão. São Paulo: Nobel, 1998.

Pensando o espaço do homem. São Paulo: Edusp, 2004.

A natureza do espaço: técnica e tempo. Razão e emoção. São Paulo: Edusp, 2008.

SCHNEIDER, Emanuelle. InFluxus: ressonâncias Fluxus no acervo do MAC USP.

Dissertação de Mestrado. Programa de Pós-Graduação Interunidades em Estética e História da Arte, Universidade de São Paulo, São Paulo, 2011.

SHAW, Edward (Org.). Seis décadas de arte argentino. Buenos Aires: Universidad Torcuato Di Tella, 1998.

SEFFRIN, Silvana (Org.). Frederico Morais. Rio de Janeiro: Funarte, 2004.

SUÁREZ, Orlando. La jaula invisible: neocolonialismo y plástica latinoamericana. Havana: Editorial de Ciencias Sociales, 1986.

TRABA, Marta. Duas décadas vulneráveis nas artes plásticas latino-americanas. 19501970. Rio de Janeiro: Paz e Terra, 1977.

WOOD, Paul. Arte conceitual. São Paulo: Cosac Naify, 2002. 
ZABALA, Horacio. CAYC: diecisiete interrogantes acerca del arte (GT-135). Buenos Aires: Centro de Arte y Comunicación (CAYC), 1972.

CAYC al aire libre (cat. exp.). Buenos Aires: Centro de Arte y Comunicación (CAYC), 1972.

. Marcel Duchamp y los restos del ready-made. Buenos Aires: Ediciones Infinito, 2012.

ZANINI, Walter. Prospectiva 74 (cat. exp.). São Paulo: Museu de Arte Contemporânea de São Paulo - MAC USP, 1974.

Década de 70 (cat. exp.). São Paulo: Museu de Arte Contemporânea de São Paulo MAC USP, 1976.

.História Geral da arte no Brasil. São Paulo: Instituto Moreira Salles; Fundação Djalma Guimarães, 1983.

As novas possibilidades. In: Poéticas visuais (cat.exp.). São Paulo: Museu de Arte Contemporânea de São Paulo - MAC USP, 1977.

\section{Sites}

http://cargocollective.com/ymago/Ranciere-Txt-2

http://www.ramona.org.ar/node/21556

http://www.roalonso.net/

https://artforum.com/inprint/issue $=196807 \& \mathrm{id}=32466$

http://cvaa.com.ar/02dossiers/CAyC/04_histo_01.php. 